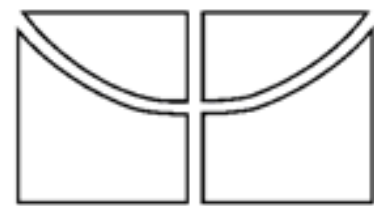

UNIVERSIDADE DE BRASÍLIA FACULDADE DE COMUNICAÇÃO PROGRAMA DE PÓS-GRADUAÇÃO

\title{
O MEME COMO LINGUAGEM DA INTERNET: UMA PERSPECTIVA SEMIÓTICA
}

\author{
Natália Botelho Horta
}

Brasília

fevereiro de 2015 


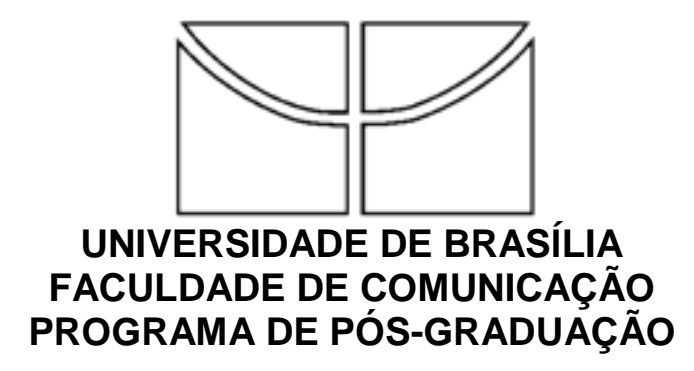

\title{
O MEME COMO LINGUAGEM DA INTERNET: UMA PERSPECTIVA SEMIÓTICA
}

\author{
Natália Botelho Horta
}

Dissertação apresentada ao Programa de Pós-Graduação em Comunicação da Universidade de Brasília como parte dos requisitos para obtenção do título de Mestre.

Linha de pesquisa: Imagem, Som e Escrita

Orientador: Prof. Dr. Sérgio de Sá

Brasília

fevereiro de 2015 
UNIVERSIDADE DE BRASÍLIA

FACULDADE DE COMUNICAÇÃO

PROGRAMA DE PÓS-GRADUAÇÃO

\section{DISSERTAÇÃO DE MESTRADO}

O meme como linguagem da internet: uma perspectiva semiótica

Natália Botelho Horta

Orientador: Prof. Dr. Sérgio de Sá

Banca Examinadora:

Prof. Dr. Sérgio de Sá - UnB

Presidente da banca

Prof. Dr. Pedro David Russi Duarte - UnB Avaliador

Prof. Dra. Claudia Maria Busato - UniCeub Avaliadora

Prof. Dr. Guilherme Nery Atem - UFF-RJ

Suplente 


\section{AGRADECIMENTOS}

Peço licença a Bakhtin para me apropriar de sua ideia de um discurso polifônico, espaço no qual ecoam diversas vozes, para dizer, sendo bastante piegas, que esta dissertação é, além de polifônica, também "policárdica", transparecendo aqui o amor, a amizade e a generosidade de muitos que me ajudaram nesse percurso e a quem agradeço imensamente. Desculpa, Bakhtin, por ser completamente brega, mas é de todo coração minha gratidão a essas pessoas.

Primeiramente, agradeço à minha família. À minha irmã, Isabela, quem me incentivou, me animou, me consolou e comemorou comigo cada etapa terminada, minha companheiríssima e futura grande mestre. À minha mãe Suely, por todo o apoio, amor infinito e conversas preciosas que me fizeram ver um horizonte menos terrível em meio a prazos e desesperos. Ao meu pai, Luiz Antônio, também pelo amor, pelos mimos, pelo entusiasmo e por tantas idas à caixa postal para buscar livros. À minha tia Andrea, pelas meditações, pelas coxinhas (ou seriam rissoles?), entre outras guloseimas motivadoras, além dos nossos longos e valiosos bate-papos.

Agradeço também ao meu grande amigo (amg) Flávio, quem esteve iluminando meus pensamentos desde o processo seletivo, em discussões, recomendações de leitura, conversas geniais no Gtalk, sempre de longe, mas sempre de perto nessa semiose louca, wow. Ao professor Pedro Russi, que muito admiro pela generosidade e conhecimento, e a quem agradeço pelas conversas, textos e sua enorme atenção e boa vontade, por mostrar sempre outras formas de pensar o mundo e a nossa relação com ele. Agradeço também ao meu orientador Sérgio de Sá pela acolhida de braços abertos na linha de pesquisa, pela disposição em ajudar, pelas discussões e questionamentos e por embarcar sem medo nessa viagem semiótica comigo.

Sou muito grata também às professoras Claudia Busato e Elen Geraldes pelas leituras, pela disponibilidade e pelas contribuições ao meu trabalho. Duas figuras femininas que são uma grande inspiração para mim como futura pesquisadora.

Agradeço também ao querido João Ricardo pela amizade e pelas conversas sobre memes, semióticas e não semióticas. Ao meu cunhado Paraná e à minha amiga Camila, companheiros mestrandos que me deram força e tranquilidade. Aos amigos Henrique, Pepas, Amanda e Thais pelo apoio e pelas risadas nas horas vagas. Muito obrigada. 
"Nunca es tiempo perdido el que se emplea en escuchar con humildad cosas que no se entienden" Eugenio D’Ors 


\section{RESUMO}

Esta dissertação intenciona investigar o meme da internet, um fenômeno cultural que se estabeleceu na rede como uma forma de comunicação, baseada na recriação excessiva, coletiva e paródica de imagens, textos verbais, vídeos, entre outros, que se espalham de forma viral. A partir de uma perspectiva semiótica, na leitura de Charles S. Peirce, Iuri Lotman, Mikhail Bakhtin e Ludwig Wittgenstein, o trabalho procura compreender o fenômeno como uma linguagem da internet. Mais que um suporte físico passivo para a transmissão de mensagens, a web é entendida aqui como um meio de comunicação, uma esfera sígnica na qual a comunicação e a geração de sentido são possíveis - na qual a cultura torna-se possível. Dessa esfera emerge o meme, que nesta pesquisa é tomado como uma forma de expressão e concepção de mundo que apresenta certa regularidade, sua "gramática". Assim, também delineamos na presente investigação as categorias que compõem essa linguagem (e forma de pensamento) e as dinâmicas estabelecidas em seus jogos de significação.

Palavras chaves: meme da internet; linguagem; meio de comunicação; semiosfera; terceiridade; jogos de linguagem; carnavalização; comicidade; paródia. 


\begin{abstract}
This dissertation intends to explore the internet meme, a cultural phenomenon that has been established on the Web as a communication mode, based on excessive, collective and parodic recreation of images, verbal texts, videos etc., which spreads virally. From a semiotic perspective, based on Charles S. Peirce, Iuri Lotman, Mikhail Bakhtin e Ludwig Wittgenstein, this work aims to understand the phenomenon as an internet language. The Web, therefore, is more than just a material passive information carrier. In this dissertation, it is understood as a mean of communication, i.e., a sphere of signs, where the communication process and the generation of meaning are possible - where the culture becomes possible. From this sphere emerges the meme, which in this work is conceived as an expression manner and a way of apprehend the world that has its regularity, its "grammar". This research establishes the categories which compose this language (and way of thought) and the dynamics set in its meaning games.
\end{abstract}

Keywords: internet meme; language; mean of communication; semiosphere; thirdness; language games; carnivalization; comicality; parody. 


\section{RESUMEN}

Este trabajo propone investigar el meme de la internet, un fenómeno cultural que se estableció en la red como una forma de comunicación, fundamentada en la recreación excesiva, colectiva y paródica de imágenes, textos verbales, videos etc., que se difunden de manera viral. A partir de una perspectiva semiótica, en la lectura de Charles $\mathrm{S}$. Peirce, Iuri Lotman, Mikhail Bakhtin y Ludwig Wittgenstein, la investigación busca comprender el fenómeno como un lenguaje de la internet. Más que un soporte físico y pasivo para la transmisión de mensajes, la web es entendida como un medio de comunicación, una esfera de signos en la cual la comunicación y la generación de sentido son posibles - donde la cultura se hace posible. De esa esfera emerge el meme, que en este trabajo es comprendido como una forma de expresión y concepción de mundo que presenta cierta regularidad, su "gramática". Así, también definimos en la presente investigación las categorías que componen ese lenguaje (y forma de pensamiento) y las dinámicas establecidas en sus juegos de significación.

Palabras llaves: meme de la internet; lenguaje; medio de comunicación; semiosfera; terceridad; juegos de lenguaje; carnavalización; comicidad; parodia. 


\section{LISTA DE ILUSTRAÇÕES}

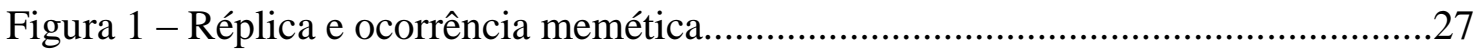

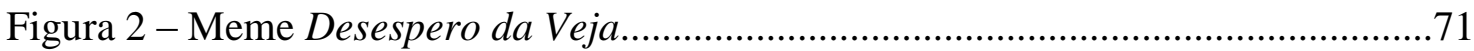

Figura 3 - Meme "Você teria coragem” ........................................................................

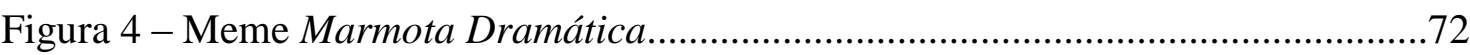

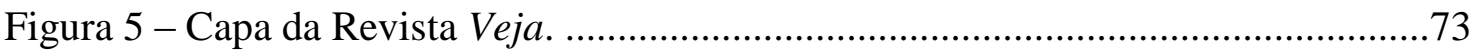

Figura 6 - peça da campanha do movimento Brasil Sem Drogas...................................74

Figura 7 - Réplica do meme Margem de Erro do Ibope .................................................94

Figura 8 - Réplica do meme Margem de Erro do Ibope................................................94

Figura 9 - Réplica do meme Margem de Erro do Ibope .................................................94

Figura 10 - Réplica do meme Margem de Erro do Ibope ...............................................97

Figura 11 - Réplica do meme Grumpy Cat .............................................................97

Figura 12 - Réplica do meme Grumpy Cat ...........................................................98

Figura 13 - Réplica do meme Grumpy Cat ................................................................98

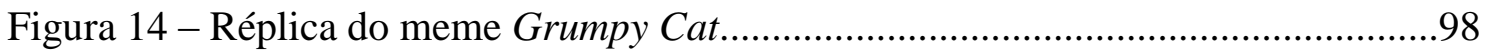

Figura 15 - Réplicas do meme Jesus Manero............................................................101

Figura 16 - Príncipe William e Kate Middleton no Palácio de Buckingham...............102

Figura 17 - Réplica do meme Royal Wedding Girl...................................................103

Figura 18 - Réplica do meme Royal Wedding Girl................................................103

Figura 19 - Réplica do meme Royal Wedding Girl.................................................103

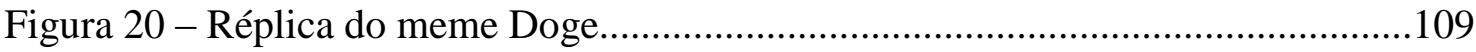

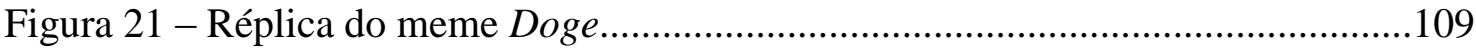

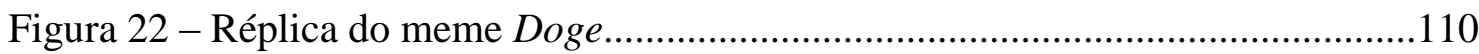

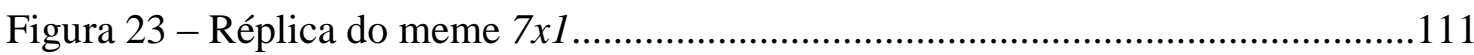

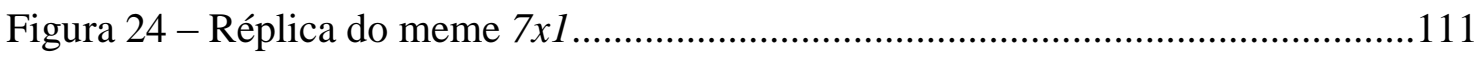

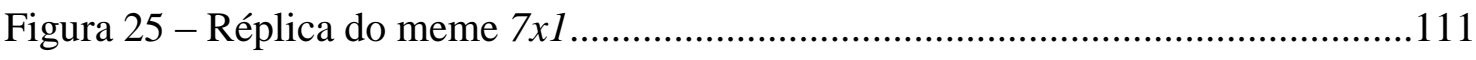

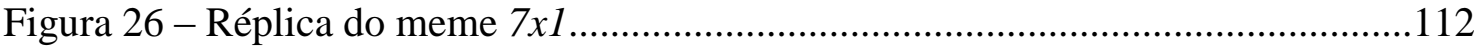

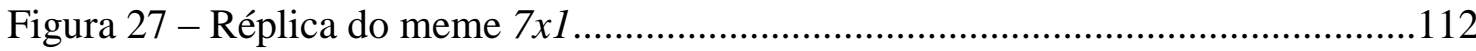

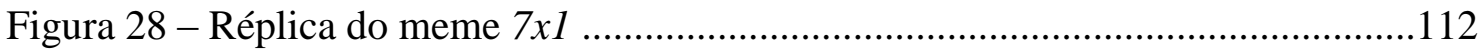

Gráfico 1 - Interesse pelo termo "desespero da veja"...............................................114

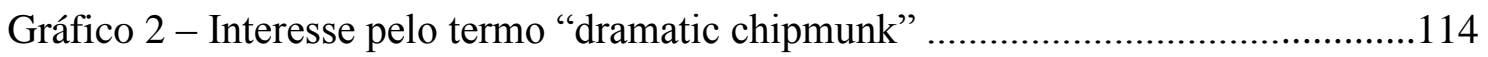


Gráfico 3 - Interesse pelo termo "doge"

Figura 29 - Antes e depois da restauração da obra Ecce Homo......................................118

Figura 30 - Réplicas do meme Ecce Mono..................................................................119

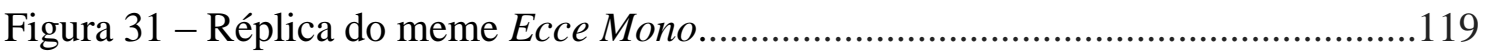

Figura 32 - Réplica do meme Ecce Mono...............................................................119

Figura 33 - Réplica do meme Ecce Mono ……....................................................120

Figura 34 - Réplica do meme Ecce Mono................................................................... 120

Figura 35 - Placa original instalada em Brasília.........................................................124

Figura 36 - Réplica do meme Placas da Copa.............................................................124

Figura 37 - Réplica do meme Placas da Copa.............................................................124

Figura 38 - Réplica do meme Placas da Copa ............................................................124

Figura 39 - Réplica do meme Placas da Copa ........................................................125

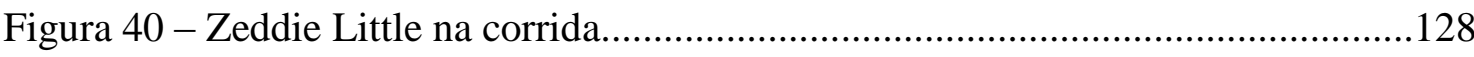

Figura 41 - Réplicas do meme Ridiculously Photogenic Guy.....................................129

Figura 42 - Fotografias de Avril Lavigne com os fãs...............................................130

Figura 43 - Réplica do meme Meet and greet de Avril Lavigne ...................................130

Figura 44- Réplica do meme Meet and greet de Avril Lavigne....................................130

Figura 45- Réplica do meme Meet and greet de Avril Lavigne....................................131

Figura 46- Réplica do meme Meet and greet de Avril Lavigne..................................131

Figura 47 - Réplicas do meme Nana Gouvêa em Desastres........................................137

Figura 48 - Réplica do meme Sophisticated Cat......................................................137

Figura 49 - Réplicas do meme Sophisticated Cat......................................................137

Figura 50 - Printscreens das réplicas do meme Harlem Shake ..................................138

Figura 51 - Imagem postada no 4chan ………........................................................... 142

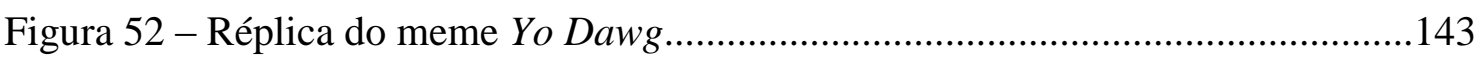

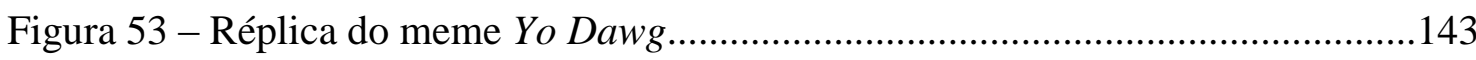

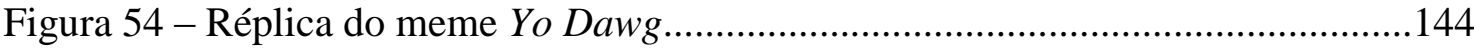

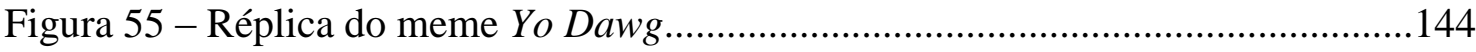

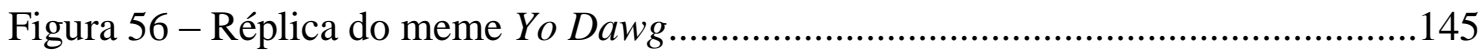

Figura 57 - Momento do gol de Van Persie..................................................................146

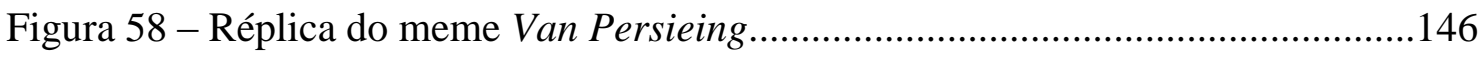

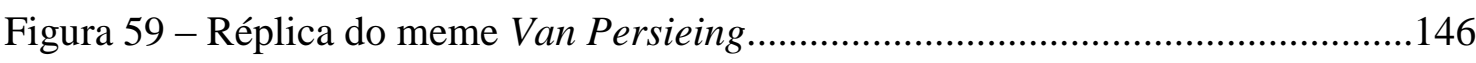

Figura 60 - Réplica do meme Van Persieing..........................................................147 
Figura 61 - Réplica do meme Van Persieing .............................................................147

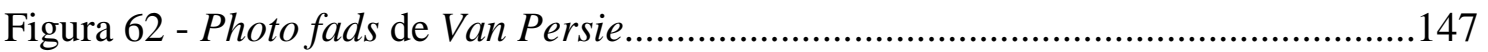

Figura 63 - Réplicas do meme Thrid World Success ....................................................152

Figura 64 - Réplicas do meme First World Problems.................................................154

Figura 65 - Réplicas do meme Willy Wonka Irônico ..................................................154

Figura 66 - Réplicas do meme Anxiety Cat........................................................... 155

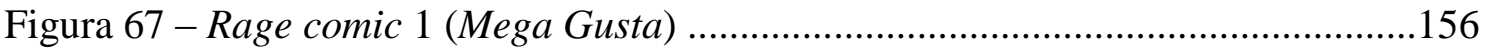

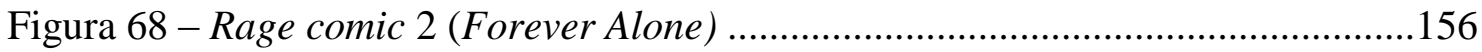

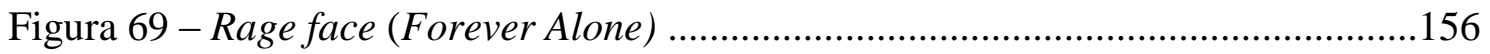

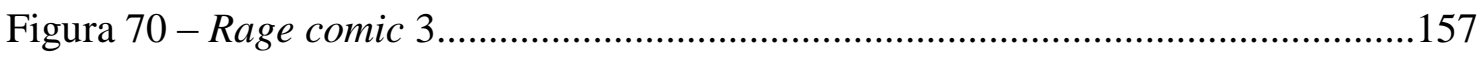

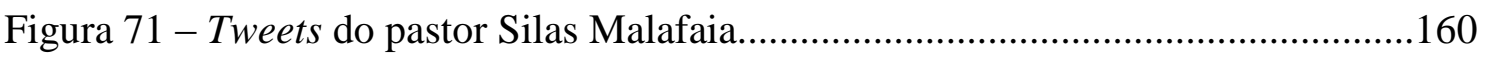

Figura 72 - Réplicas do meme Marina Silva e Silas Malafaia....................................161

Figura 73 - Réplica do eme Marina Silva e Silas Malafaia ...........................................162

Figura 74 - Réplica do meme Marina Silva e Silas Malafaia .......................................162

Figura 75 - Réplica do meme Marina Silva e Silas Malafaia ........................................163 


\section{ÍNDICE}

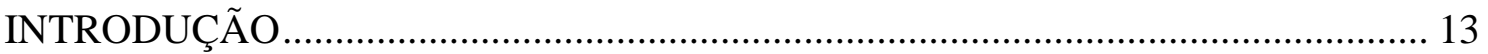

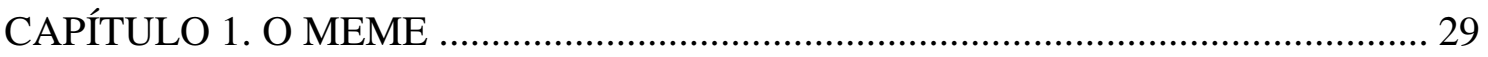

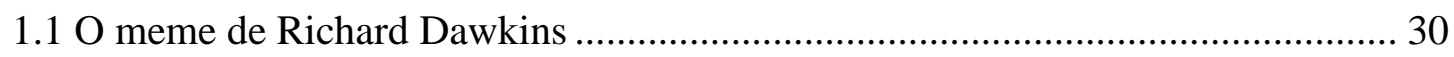

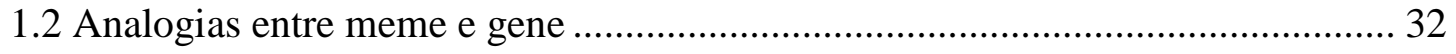

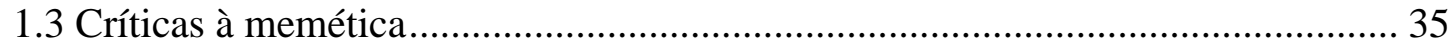

1.4 Provocações e aproximações: o meme da memética e o meme da internet........... 40

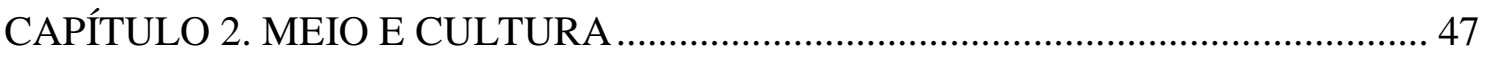

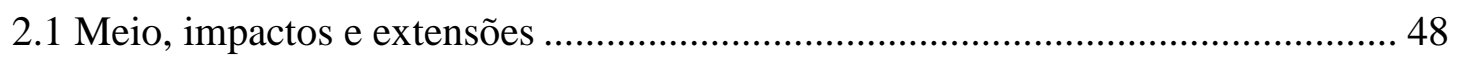

2.2 A internet como extensão da consciência ......................................................... 51

$2.3 \mathrm{O}$ espaço semiótico da cultura e da linguagem ..................................................... 54

2.4 Um retorno ao meme de Richard Dawkins ......................................................... 59

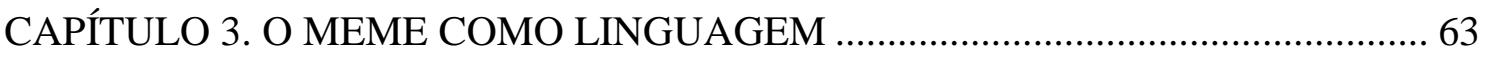

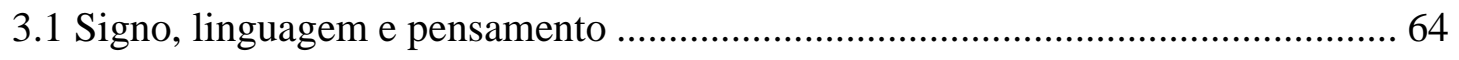

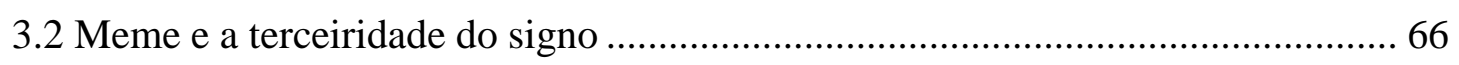

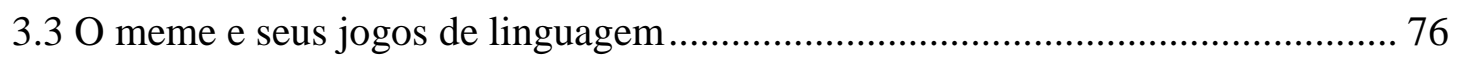

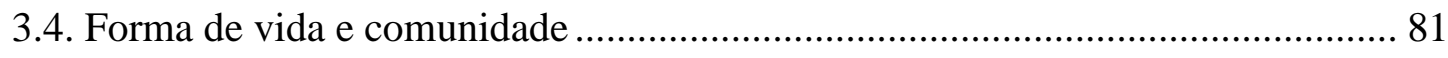

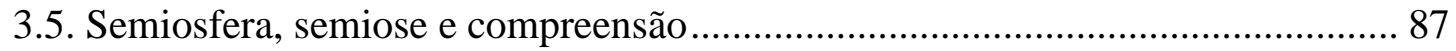

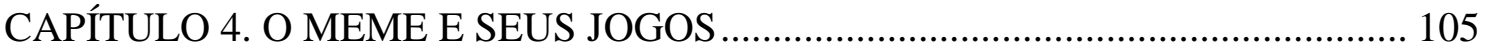

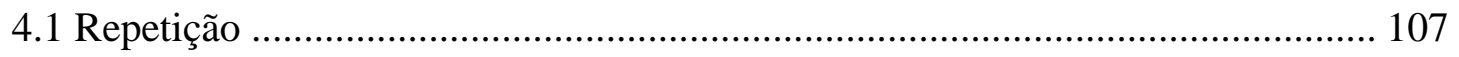

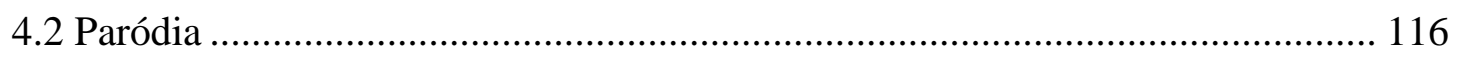

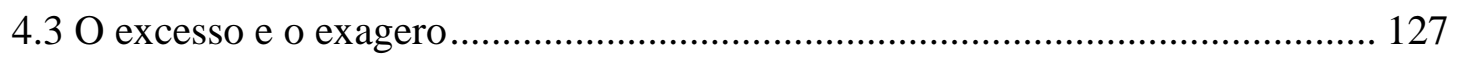

4.4 A carnavalização e a concepção cômica do mundo........................................... 132

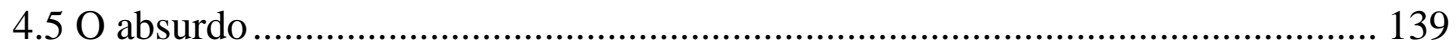

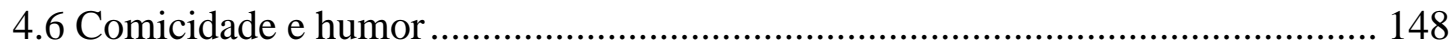

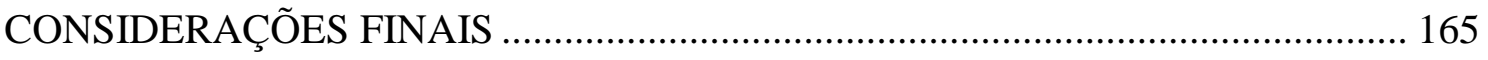

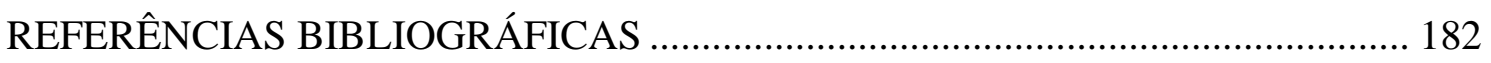




\section{INTRODUÇÃO}

Esta dissertação visa compreender uma manifestação cultural que tem ganhado destaque na internet nas duas últimas décadas: os chamados memes. No presente trabalho, buscaremos lançar luz a esse objeto em uma perspectiva semiótica, compreendendo-o como um fenômeno de linguagem, que emerge de práticas comunicacionais em um meio (a web) que, como veremos a seguir aqui, é tomado como uma esfera sígnica.

O termo que batiza o nosso objeto foi originalmente cunhado pelo etólogo Richard Dawkins que, vislumbrando uma relação de sua teoria do "egoísmo do gene" com a cultura, concebeu o vocábulo para abarcar a ideia do que seria um correspondente do gene no caldo cultural humano. Desse modo, para ele, o meme é uma unidade de replicação e, assim como o gene que salta de corpo para corpo carregando uma informação, o meme circula de cérebro em cérebro por meio de um processo que, de maneira ampla, pode ser chamado de imitação (DAWKINS, 2007, p. 330). O etólogo não definiu precisamente qual seria essa unidade, portanto, entendemos que, com seu construto teórico, ele estava buscando uma noção geral do devir da cultura, tanto é assim que exemplifica como meme objetos bastante diferentes, como "melodias, ideias, slogans, as modas no vestuário, as maneiras de fazer potes ou de construir arcos" (idem).

Já no contexto das práticas comunicacionais da internet, o uso do termo abrange "ideias, brincadeiras, jogos, piadas ou comportamentos que se espalham através de sua replicação de forma viral" (FONTANELLA, 2009b, p. 8) e que, por vezes, são caracterizados pela repetição de um modelo formal básico, manifestando-se por meio de vídeos, frases, hashtags, foto-legendas, tirinhas, entre outros. Os memes, em grande parte, são produzidos em baixa qualidade técnica, possuindo, em alguns casos, um aspecto grosseiro e intencionalmente descuidado, além de serem realizados de forma lúdica e com uma aparente pretensão de provocar um efeito risível.

O primeiro registro do uso da palavra "meme" na internet é de 1998, quando Joshua Schachter, um dos elaboladores do Delicious', criou um site chamado

${ }^{1}$ Delicious é um site que oferece o serviço de armazenagem, compartilhamento e descoberta de favoritos (bookmarks). 
Memepool que reunia links virais e outros conteúdos. Em seguida, no começo dos anos 2000, Jonah Peretti, que havia criado um site chamado Contegious Media, pelo qual fazia experimentos virais, realizou, com um grupo de amigos, um "festival de virais" que contou com a presença de várias personalidades influentes na disseminação e criação de artefatos culturais na web. De acordo com Kenvatta Cheese, um dos cocriadores do Know Your Meme $^{2}$, nesse evento a teoria de Dawkins foi relembrada e a partir de então o termo "meme" começou a ser utilizado para definir tudo aquilo que se espalhava na internet. $\mathrm{O}$ uso do vocábulo foi reforçado também com sua utilização em entrevistas dadas por aqueles que estavam presentes no festival ${ }^{3}$. Algumas manifestações culturais na rede receberam, assim, o nome de meme, que é entendido pela cibercultura como um fenômeno parte do digital trash $^{4}$, uma estética cuja breve revisão é válida nesse momento introdutório a título de contextualização de nosso tema.

O termo trash, cuja tradução para o português seria o substantivo "lixo", também possui a função morfológica de adjetivo sendo utilizado, tanto em português como em inglês, para "qualificar produtos artísticos de baixa qualidade, como um programa de televisão sensacionalista" (PRIMO, 2007a). Para a indústria midiática, portanto, o vocábulo pode referir-se tanto a produtos que não estão dentro dos padrões técnicos por ela estabelecidos, produções amadoras ou semiprofissionais e também, do ponto de vista do conteúdo, programas violentos, sensacionalistas ou de exploração da nudez. No entanto, nas últimas décadas, o termo veio ganhando um novo significado, e passou a referir-se a produtos que compartem uma mesma estética, muitas vezes tosca, e uma mesma abordagem, geralmente crítica, sarcástica e politicamente incorreta (idem). E é dessa acepção mais recente que se trata o termo que tem sido utilizado para definir um conjunto de manifestações ciberculturais.

Dessa maneira, o digital trash, vocábulo adotado a partir da gíria dos usuários da internet, consiste, para a cibercultura, em um fenômeno que abriga a produção, a reprodução e o compartilhamento de criações textuais (imagéticas, audiovisuais, verbais), fundamentadas em uma estética propositalmente descuidada e difundidas de maneira viral nas redes sociais. $\mathrm{O}$ vocábulo não define uma categoria com limites bem

\footnotetext{
${ }^{2} \mathrm{O}$ knowyourmeme.com é um banco de dados de memes, principalmente memes norte-americanos. No site, o usuário encontra diversos artigos, com vídeos e imagens, que explicam a origem dos memes e o seu funcionamento.

${ }^{3}$ Fonte: < http://youpix.virgula.uol.com.br/memepedia/a-origem-do-termo-meme-na-internet/ > Acesso em 21/1/2015

${ }^{4}$ Para maiores considerações acerca do digital trash, ver: LEMOS, 2005; PRIMO, 2007a; RECUERO, 2007b; PEREIRA e HECKSHER, 2008; FONTANELLA, 2009, 2011.
} 
determinados ou formas completamente estáveis, mas a noção geral trazida por ele é compreendida com facilidade por aqueles que estão inseridos no ambiente comunicacional dos meios digitais (FONTANELLA, 2009a, p. 3). Além dos memes, como exemplos de manifestações que são parte dessa cultura, podemos citar paródias audiovisuais (spoofs); imagens grotescas enviadas por email; edições de vídeos a partir de trechos de áudio extraídos de peças das mídias de massa (funks); fotomontagens; páginas de personagens ou perfis não oficiais de celebridades, nos quais elas são "emuladas de forma caricatural" (fakes); socioletos, gifs e foto-legendas (idem).

A variedade dos exemplos e a quantidade de imagens, vídeos e frases prontas que cada um abriga transparecem mais um traço dessa cultura do trash, recuperando o sentido original do termo, "lixo": o digital trash se configura também como a cultura dos excessos e da abundância. É trash não só no sentido estético adquirido mais recentemente, é trash porque é lixo, no sentido de que se tem informação de sobra:

\footnotetext{
A apropriação social das máquinas de comunicação, como quer Perriault, se dá como um método de improvisação, onde os desvios do uso são responsáveis pelos desenvolvimentos na indústria da informática e por sua popularização. Assim, a sociedade da informação entra numa fase de excesso e de profusão desenfreada de informações, de "lixo". (LEMOS, 2007)
}

Nessa passagem, Lemos faz referência a dois momentos da internet dos quais nos fala também Fontanella. O primeiro deles tem início na década de 90, quando ela torna-se acessível aos usuários fora dos ambientes acadêmicos, aos quais ela estava anteriormente restrita (FONTANELLA, 2011, p. 1), e é nesse sentido que Lemos menciona "a apropriação social das máquinas de comunicação". O segundo momento, "a fase de excesso", refere-se ao que a cibercultura chama de Web 2.0 $0^{5}$, um período de "domesticação", termo usado por Fontanella para caracterizar uma fase em que a internet "deixa de ser novidade" e passa a fazer parte do cotidiano, um momento que "exigiu um processo de mediação cultural que aproximasse a tecnologia dos interesses de grupos sociais específicos" (ibidem, p. 2). Seria, portanto, nesse segundo momento que teriam surgido os primeiros memes da internet, cujas manifestações iniciais emergiram de redes sociais americanas menos conhecidas pelo "grande público", como

\footnotetext{
${ }^{5} \mathrm{O}$ termo Web 2.0 foi popularizado a partir de 2004 pela companhia de mídia (editora) americana O'Reilly Media e, segundo Alex Primo (2007b, p. 2), refere-se à "segunda geração de serviços online e caracteriza-se por potencializar as formas de publicação, compartilhamento e organização de informações, além de ampliar os espaços para a interação entre os participantes do processo". Enquanto na primeira geração da internet os sites operavam como unidades isoladas, nessa segunda geração, surge uma "estrutura integrada de funcionalidades e conteúdos", onde aparecem blogs, wikis, redes sociais, jornais online, entre outros (idem).
} 
os fóruns de discussão estilo imageboards ${ }^{6}$, também chamadas de chans (FONTANELLA, 2010, p. 2), para depois conquistarem espaços "mais populares" da rede.

Posta, assim, essa breve contextualização a partir da cibercultura, passemos ao percurso de construção de nosso problema de pesquisa. Ressaltamos desde já que no presente trabalho procuraremos dar continuidade ao empreendimento de melhor compreender o meme, um processo já iniciado por alguns desbravadores dessas manifestações culturais da web, dando continuidade às reflexões sobre o tema, discutido tanto em espaços mais informais como em espaços acadêmicos ${ }^{7}$. Nessa tarefa, pretendemos encontrar os elementos partilhados por essas diversas manifestações, levando em consideração principalmente seu caráter comunicacional e semiótico. Não se trata, portanto, de entender o meme, como Dawkins os definiu primeiramente, como uma informação que é simplesmente transmitida, repassada de cérebro para cérebro, visão que implica certa passividade dos sujeitos, além de situar apenas na cabeça os fenômenos mentais. Essa proposta, que nasce de uma analogia com o gene, parece não dar conta dos aspectos que enxergamos nos memes. Desse modo, buscaremos outra maneira de abordar o fenômeno, sem ignorar as provocações que o construto de Dawkins nos traz. Esta investigação, portanto, almeja compreender o meme como uma maneira encontrada pelos usuários de entender o mundo, ressignificando as informações que se apresentam em seu cotidiano, algo que implica mediação, compreensão e crescimento sígnico. É nesse sentido que gostaríamos de lançar luz aos memes da internet. Vejamos assim, com base em nossas inquietações iniciais, como esta pesquisa visa entender o fenômeno e o porquê de nossas escolhas teóricas.

\footnotetext{
${ }^{6}$ Esses fóruns, que seguem a estrutura dos fóruns online japoneses, demandam que, para iniciar um tópico de discussão, seja postada uma imagem, já para responder, o uso de imagens não é obrigatório. Contudo, o design destas redes sociais privilegia o uso de figuras para estabelecer a comunicação, o que acaba valorizando o seu uso nas respostas, que geralmente são fotos ou ilustrações editadas, acrescidas de texto verbal, quase sempre em um tom irônico (FONTANELLA, 2010, p. 2-3).

${ }^{7}$ Entre os trabalhos pesquisados, encontramos diversos artigos sobre o tema e alguns poucos trabalhos mais extensos. De forma geral, muito dos artigos produzidos sobre os memes da internet, apresentados em eventos da área no Brasil, como congressos e simpósios da Sociedade Brasileira de Estudos Interdisciplinares da Comunicação (Intercom) e da Associação Brasileira de Pesquisadores em Cibercultura (Abciber), bem como os artigos encontrados em língua estrangeira, se resumem a explicações superficiais presas a descrições de alguns memes, sem fazer muitos avanços na discussão do fenômeno e suas consequências, mecanismos e relações com as práticas comunicacionais. No entanto, entre estes trabalhos, também se encontram alguns autores que conduziram brilhantemente a discussão, entre os quais destacamos alguns: Fernando Fontanella (2009a, 2009b, 2011, 2012), Matt Morain (2009),Vilson Filho e Francisco Fialho (2011), Ryan Milner (2012), Ronaldo Henn (2014).
} 
Pela vivência e experiência com o tema, uma dessas primeiras inquietações, isto é, algo que nos instigou a debruçar-nos sobre o meme logo no "período embrionário" da pesquisa, foi o fato de que diversas manifestações aparentemente bastante diferentes eram definidas pelo mesmo vocábulo. Assim, havia na rede conjuntos de fotografias, séries de montagens, grupos de foto-legendas, frases no Twitter, entre outros agrupamentos muito distintos entre si, sendo definidos pelo mesmo termo: meme. Isto nos fez questionar que traços haveria em comum entre eles para que estivessem sendo compreendidos e referidos da mesma maneira. Uma segunda observação feita diz respeito ao fato de que esses memes sempre repetiam algo - um tema, uma imagem, um modelo - e, ao mesmo tempo, propunham uma interferência do usuário nisso que estava sendo repetido, se adaptando a diversos contextos e ao que esse emissor queria expressar. Outro aspecto dessas manifestações que também nos chamou a atenção foi o fato de que qualquer informação poderia se tornar um meme: a fotografia de uma notícia, uma ilustração, uma frase de um vídeo publicitário, um personagem de determinado filme ou até mesmo cenas de nossas vidas cotidianas, como um retrato de um animal de estimação. De um modo que parecia ser aleatório, essa informação era apropriada pelos usuários e ressignificada diversas vezes.

Essas observações, principalmente a segunda, que nos sugeria a ideia de que havia uma espécie de norma - algo que estava presente em todas as manifestações díspares em um primeiro olhar - somadas à vivência e interesse pela semiótica, além do entusiasmo pela linguística e pela filosofia da linguagem, nos permitiram entender que esses artefatos culturais eram signos organizados de uma maneira particular que levava à emergência de uma significação, seguindo uma espécie de regra: seriam, portanto, um tipo de linguagem.

Buscando relacionar esse entendimento ao meio de comunicação, ao mesmo tempo comparando a internet a outros meios, ocorreu-nos questionar se o meme não poderia ser entendido como linguagem da internet, uma vez que recorrentemente vemos a ideia de linguagem associada a um meio de comunicação ou a uma técnica, por exemplo, a "linguagem fotográfica", a "linguagem televisiva", a "linguagem cinematográfica". Poderíamos pensar, então, em uma linguagem da internet? Para tentar responder a essa questão, avançando na formulação do problema de pesquisa, buscamos inicialmente o conceito de gramática dos meios, discutido pelo pensador canadense Marshall McLuhan, partindo de dois artigos: As tecnologias de comunicação como gramáticas: meio, conteúdo e mensagem na obra de Marshall McLuhan, de Vinícius 
Andrade Pereira, e Gramática dos meios no contexto das linguagens icônicas, de Irene Machado.

Para Pereira, a ideia de gramática dos meios é construída nos estudos de McLuhan quando este propõe investigar os meios enquanto extensões tecnológicas do homem, explorando o entendimento do meio enquanto meio ambiente, substância envolvente (PEREIRA, 2004):

Todo meio ou tecnologia cria um ambiente de serviço. Desse modo, o motor do carro cria super-rodovias, subúrbios, postos de gasolina, etc. É este ambiente de serviço e desserviço que eu chamo de meio. Uma vez que este ambiente de serviços é um tipo de "texto", ele tem a sua própria sintaxe e gramática. É esse meio que invade e reforma cada aspecto da vida social e física dos usuários da tecnologia, não importa para que o carro ou o rádio ou a TV sejam usados. (MCLHUAN apud PEREIRA, 2004, tradução nossa ${ }^{8}$ )

Dessa maneira, ele introduz o que McLuhan entende por linguagem de um meio, isto é, sua gramática: uma vez que esse ambiente mediático é uma espécie de texto, ele possui uma gramática que o organiza. Pereira compreende, assim, a linguagem como a organização, a ordem, a forma do texto e destaca que o ponto crucial para esse entendimento está na concatenação entre as ideias de forma e de processos de produção de significados, nos termos de McLuhan, entre meio, mensagem e conteúdo (idem.). Assinala que cada tecnologia, atuando como uma linguagem, condicionando o sistema ${ }^{9}$ a novos padrões cognitivos e perceptuais, assim como o que aconteceu com a poesia declamada na Grécia Antiga ${ }^{10}$ estudada por Havelock: "Por isso, um meio tal como a poesia oral grega ou a TV, sendo meios compatíveis com o sistema humano, impõem suas linguagens de tal forma que os sistemas envolvidos se tornam reprodutores das

\footnotetext{
8 "Every medium or technology creates a service environment. Thus the motor car creates super-highways, suburbs, gas stations, etc. It is this environment of service and disservice which I call medium. Since this environment of services is a kind of "text", it has its own peculiar syntax and grammar. It is this medium which invades and reshapes every aspect of the social and psychic life of the users of the technology, regardless of what the car or radio or TV set is used for...".

${ }^{9}$ Para Pereira, a ideia de sistema é "aplicada como alternativa à ideia de espécie" e funciona "como estratégia para enfatizar as hibridações de um organismo vivo com tecnologias". "Cada sistema, porém, tratando-se de sistemas complexos, possui um conjunto mnemônico único - ainda que com uma série de memórias comuns, como é o caso, por exemplo, da mesma língua para um dado grupo social - o que permite que as gêneses de significados apresentem produtos semióticos distintos, mesmo diante de um objeto percebido de forma semelhante, por dois sistemas do mesmo tipo" (PEREIRA, 2004).

${ }^{10}$ Para discutir a relação entre conteúdo, mensagem e significado na obra de McLuhan, Pereira retoma as análises do autor canadense sobre os estudos de Havelock a respeito da recitação poética na Grécia, salientando o papel da linguagem como o mecanismo cognitivo e sensorial que permite a realização das mensagens. Ele mostra que a arte recitatória não deveria ser tomada como um ato de imitação da plateia ao que o poeta proferia, mas sim como uma forma de participação do público que ressoava e encenava junto com o artista, no qual todos entravam numa espécie de transe hipnótico, a partir da mobilização do sistema nervoso, condicionados, assim, à memorização dos poemas. Dessa maneira, a célebre frase de McLuhan, "o meio é a mensagem", não retrataria a desvalorização dos conteúdos de um meio, e sim, denotaria que o autor canadense estava assinalando a possibilidade de os meios alavancarem efeitos que atuariam paralelamente ao conteúdo da mensagem (idem).
} 
suas linguagens, respondendo de maneira mais ou menos homogênea na produção dos seus recortes perceptuais e na produção de mensagens" (idem). Esse recorte deve ser entendido como a aplicação de uma ordem, isto é, de uma gramática, que absorve e rearranja as informações, gerando assim mensagens, sobre as quais o sistema agirá na busca de gerar significações. Nesse sentido, não pode haver mensagem sem uma gramática, que se apresenta a partir das características de determinado meio, e sem um usuário/sistema que revela essa mesma gramática. Para Pereira, "uma gramática é uma tecnologia que só ganha movimento, utilidade, enfim, dinâmica, quando usada" (idem).

Já Machado propõe uma reflexão sobre a transformação dos códigos elétricoeletrônicos em informação codificada culturalmente, isto é, uma linguagem icônica, que corresponde a códigos não diretamente alfabéticos. O que McLuhan propunha, segundo a autora, era que havia uma espécie de tradução da informação elétrica em códigos culturais. A informação elétrica, assim, organiza-se por padrões e estruturas (ondas sonoras, pontos de luz, formas gráficas, projeções audiovisuais e cinéticas) que movimentam processos sensoriais (MACHADO, 2012, p. 9). A gramática do meio atuaria, assim, ordenando essas informações elétricas e as tornando inteligíveis, a começar pelo reconhecimento da informação elétrica que se torna de fato efeito sensorial a partir do treino da percepção e, por fim, dependente dessa percepção distintiva de padrões, configura-se o pensamento, que dá o estatuto de linguagem às ações dos signos contínuos da eletricidade (idem). Machado salienta ainda que McLuhan definia a eletricidade como "informação pura", com o intuito de abrir caminho para a compreensão de linguagens que não se elaboravam diretamente no código alfabético, mas em torno de estruturas e padrões icônicos (ibidem, p. 4). Essa informação pura envolve e submete o sensório continuadamente, promovendo por um lado uma imersão no ambiente da informação e por outro provocando um sentimento de alienação. Ao conflito entre participação e alienação McLuhan deu o nome de "entretenimento", não no sentido de um gênero televisivo, mas como um "ato de compenetração pressuposto no exercício cognitivo", uma ampliação da interação proporcionada pelo meio como extensões dos sentidos corpóreos (ibidem, p. 11), o estado de transe que Pereira ilustra ao retomar os estudos da arte recitatória na Antiga Grécia.

Assim, a proposta de Pereira de gramática dos meios frisa que as características de um meio e a maneira como ele é usado definem um recorte inicial de mensagens sobre as quais um sistema irá agir. Já Machado sugere que o recorte dessa gramática se 
dá quando as informações físicas são inicialmente reconhecidas e percebidas, configurando em seguida o pensamento. A gramática seria então esse conjunto de características que de alguma forma influenciam a construção de significado das mensagens, atuando paralelamente ao conteúdo. Nesse sentido, entendemos que o meme não poderia ser comparado a uma gramática de um meio, contudo reconhecemos que a forma que ele se estabelece é de alguma maneira influenciada pelas características desse meio em que circula.

Portanto, a formação de novos significados de uma informação por meio da replicação que, em um primeiro olhar, nos pareceu chave para a compreensão do meme, não poderia ser explicada de forma satisfatória exclusivamente pelo conceito de gramática dos meios, bem como a questão da ressignificação de qualquer informação e a sua transformação pelo meme ou mesmo o entendimento de um conjunto de regras. Faltava algo, assim, nesse primeiro caminho inferencial que fizemos para entender alguns aspectos do meme, bem como nos faltou em Dawkins elementos para lançar luz ao meme da internet, que não era exatamente o meme do etólogo. A passagem pela compreensão de linguagem a partir do conceito de gramática dos meios, contudo, permitiu uma reformulação do projeto de pesquisa inicialmente apresentado, levando essa investigação a ser conduzida pelos seguintes questionamentos: o meme pode ser entendido como uma linguagem da internet? Como podemos entendê-lo enquanto linguagem desse meio? E o que caracteriza essa linguagem? Para buscar respostas, essa investigação se propõe a tomar o processo de transformação da informação pelo meme como uma forma de comunicar e entender o mundo, compreendendo o ambiente mediático da internet como um ambiente também semiótico.

Problematizando, assim, o tema, cabe revisar pontos da teoria de Dawkins, que também fomentaram alguns questionamentos, buscando compreender por que o termo "meme" foi associado a essa manifestação cultural, bem como observar que caminhos essa apropriação do vocábulo nos aponta para o entendimento do meme da internet. Ponderamos também que antecedem ao entendimento do meme como uma linguagem da internet algumas outras noções, como a própria ideia de meio de comunicação e a de linguagem. Nesse sentido, o que significa dizer que a internet pode ser tomada como um meio de comunicação? Que tipo de relação deve estabelecer para ser entendida como tal? E como o ambiente da rede pode ser compreendido como um ambiente também semiótico? Como se torna possível a emergência de uma linguagem nesse espaço? Discutido isso, podemos pensar também as implicações de tomar o meme como 
linguagem, procurando delinear quais seriam suas "normas", de que maneira elas se configuram, como podem dar sentido ao mundo e de que forma o fazem. Desse modo, podemos avançar em nossas questões iniciais, tornando claro o entendimento de como o meme ressignifica algo e também compreender como o objeto que é ressignificado tem potencial para isso. Em nosso curso investigativo, nos propomos também a lançar luz a como os textos produzidos por essa linguagem são compreendidos (ou incompreendidos), pensando a relação entre linguagem e cultura. Outra questão inicial a ser discutida é que, se identificamos que há em todos os memes uma repetição, poderíamos pensar que essa repetição se dá de um modo particular? Que maneira seria essa? O mesmo é válido para a observação das ideias de apropriação e recriação e, nesse sentido, como poderíamos explicá-las e caracterizá-las? Por fim, assinalamos que o fenômeno é muitas vezes associado ao cômico, contudo nas leituras realizadas, não encontramos reflexões sobre esse aspecto, que por vezes é somente identificado, associando o meme a ideia de piada, humor, ironia ou sarcasmo. Desse modo, como poderíamos entender esse traço de comicidade no meme? Como pode o meme ser risível?

Com a pesquisa partindo desse cenário, encontramos na semiótica - ciência dos signos e dos processos significativos (semiose) na natureza e na cultura (NÖTH, 1995, p. 17) - maneiras de entender nossas dinâmicas de comunicação e nossa compreensão do mundo pelo meme, tomando-o como processo sígnico, o que nos permitir explorar as relações estabelecidas por ele como linguagem. $\mathrm{O}$ meme pode ser pensado, assim, como ação do signo, isto é, uma mediação estabelecida entre algo a que ele se refere, ou se aplica, e os efeitos que são produzidos na mente de quem se põe em relação a esse objeto - informações "lidas e escritas" em sua linguagem. Dessa forma, se compreendermos o processo comunicativo, colocado aqui de modo simples, como a emissão e a recepção de mensagem, é certo que essa dinâmica envolve representação, mediação e compreensão, não podendo haver, assim, comunicação sem essa ação do signo - articulação que nos permite superar também algumas limitações da teoria de Dawkins, que a princípio não parece se ocupar do meme como um processo que envolve o entendimento.

A semiótica nos possibilita, assim, a pensar o próprio campo da Comunicação ${ }^{11}$, revelando a natureza de seu objeto. Como nos mostra Ferrara (2004), o objeto dessa

\footnotetext{
${ }^{11}$ Utilizamos a inicial maiúscula para referenciar a disciplina Comunicação e a inicial minúscula quando tratamos do processo comunicacional.
} 
ciência se apresenta como relações comunicativas (relações intersubjetivas face a face ou mediadas por normas institucionais) e vínculos comunicativos (relações mediadas por recursos tecnológicos) sendo ambos sustentados pela semiose, como produção de sentidos e interpretações. Portanto, por mais que haja uma interferência da tecnologia na relação comunicativa, isso não apaga a sua natureza sígnica:

\section{[...] muito além de oferecer subsídios que fundamentem uma Teoria da Comunicação (Machado.2002), a semiótica revela-se como leitura das representações e da sua lógica. Nela, é possível perceber como as representações constituem mediação das relações sociais que falam através de signos e códigos e, sobretudo, daquela lógica que estrutura e organiza suas manifestações fenomênicas e cotidianas. (FERRARA, 2004)}

Nesse sentido, pela semiótica podemos compreender o devir do meme como relações de referência, ligações contextuais, processos de emissão e efeitos produzidos em um receptor, isto é, como o próprio processo comunicativo:

\footnotetext{
Para a semiótica, o que interessa são todos os tipos de signo possíveis, verbais, não-verbais e naturais, seus modos de significação, de denotação de informação; e todo o seu comportamento e propriedades. Que poderes de referência eles têm, como se contextualizam, como se estruturam em sistemas e processos, como são emitidos, produzidos, que efeitos podem provocar nos receptores, como são usados, que consequências podem advir deles a curto, médio e longo prazo? Eis aí questões que cabe a semiótica investigar. (SANTAELLA; NÖTH, 2004, p. 76)
}

É também por essa ciência que podemos vislumbrar o meio de comunicação no qual se configura o meme mais que como um simples suporte, mas também como uma esfera de geração de sentidos, um ambiente propício às interações simbólicas. A semiótica é, assim, uma forma de entender o meme, que se dá em uma relação mediada pela tecnologia, isto é, como um vínculo comunicativo, a partir da "iluminação de seus processos interpretativos através de signos" (ibidem), mostrando que sua natureza é sígnica.

Dentre as escolas e os autores cujos estudos integram o quadro dessa ciência, optamos por trabalhar alguns conceitos de dois deles, Iuri Lotman e Charles Sanders Peirce, dialogando com a filosofia da linguagem de Ludwig Wittgenstein e o pensamento de Mikhail Bakhtin, que dentre as muitas contribuições estão as para o campo da semiótica.

O primeiro que acabamos de citar, o semioticista russo Iuri Lotman (19221993), foi o fundador da semiótica da cultura em Tartu, na Estônia. Estudou os processos comunicativos baseado nas teorias clássicas da informação e da comunicação e teve influência de Roman Jakobson. Lotman buscou entender o signo em sua complexidade, de modo que as investigações em Tartu se ocupavam de sistemas de 
signos, compreendendo que esses sistemas não funcionavam de modo isolado, operando em um espaço que ele concebeu como semiosfera. Nesta pesquisa, partiremos, assim, desse conceito, entendido como o espaço em que a comunicação se torna possível, o que nos permitirá compreender a relação da cultura com a linguagem, bem como vislumbrar o meio como um dispositivo pensante dotado de inteligência e memória, que possibilita processos de transformação e compreensão dos textos codificados na linguagem do meme.

O outro filósofo cujo pensamento irá contribuir com a nossa investigação é o norte americano Charles Sanders Peirce (1839-1914), cujos escritos estão distribuídos nos mais diversos campos de conhecimento, dentre os quais podemos citar a matemática, a física, a astronomia, a história e a literatura. A despeito dessa heterogeneidade em seus estudos, suas investigações convergiam para a semiótica, "concebida como filosofia científica que possui toda generalidade necessária a um corpo filosófico de pensamento" (SANTAELLA; NÖTH, 2004, p. 158). Na presente pesquisa, para compreender o que faz do meme uma linguagem, nossas concatenações partem de seus conceitos de terceiridade, signo (e seus interpretantes: imediato, dinâmico e final), legi-signo e semiose. O pensamento de Peirce tornará mais clara a configuração das "normas" dos memes, nos possibilitando entender o que conecta manifestações aparentemente tão distintas, bem como facultando a nossa compreensão do próprio processo de entendimento do mundo que se dá na semiose, na mediação do signo. É válido ressaltar que não pretendemos simplesmente basear este estudo no construto teórico de Peirce de forma instrumentalizada, forçando uma categorização do meme dentro da categorização dos signos desenvolvida pelo autor. Nossa proposta, na realidade, consiste na intenção de entender nosso objeto como linguagem e, como tal, uma forma de mediação entre mundo e pensamento, entre objeto e interpretante.

Em diálogo com esses autores também está o filósofo austríaco Ludwig Wittgenstein (1889-1951), cujos escritos versam sobre os fundamentos da matemática e da lógica, a filosofia da linguagem e da mente, e a natureza da própria filosofia. Costuma-se considerar seu pensamento dividido em duas fases, a primeira marcada pela obra Tractatus Logico-Philosophicus e a segunda pelas Investigações Filosóficas, sendo esta uma crítica à tese da primeira, contudo, ambas possuindo o interesse em analisar a linguagem como método de reflexão filosófica. Desses dois momentos da filosofia de Wittgenstein, ocupar-nos-emos do segundo, em que o autor articula o conceito de jogos de linguagem, que, dialogando com Peirce, proporcionará uma maneira de compreender 
o estabelecimento das "regras" do meme, isto é, o que ele possui de regular, mostrandonos também que, além da regularidade, nos jogos de linguagem há algo irrepetível e contextual. $\mathrm{O}$ autor também nos permite tomar a linguagem como um empreendimento público e coletivo.

Dentre os autores trabalhados também está o pensador russo Mikhail Bakhtin (1895-1975), que tinha um especial interesse em estudar a linguagem humana e, por meio dela, entender a relação entre sujeitos, sujeito e sociedade, a estética e a ética. Seus escritos dialogaram e contribuíram para a crítica da religião, o estruturalismo, a semiótica, o marxismo, a crítica literária, entre outros (FARACO et al., 1996, p.7). Bakhtin também fez parte de um grupo conhecido como Círculo de Bakhtin, do qual, entre outros, participavam o linguista Valentin Voloshinov (1895-1936) e o teórico literário Pavel Medvedev (1891-1938), que possuem obras escritas em co-autoria com o filósofo russo. Entre as ideias desenvolvidas pelo grupo, destacamos o dialogismo, que compreende a linguagem como processo de interação entre os interlocutores, de forma que, para Bakhtin, a língua materna não é conhecida por meio dos dicionários ou manuais de gramática, mas sim "pelos enunciados concretos que ouvimos e reproduzimos na comunicação efetiva com as pessoas que nos rodeiam" (BAKHTIN apud CRESPO; KAESER, 2011). Essa maneira de entender a linguagem verbal, proposta por Bakhtin, nos auxiliará a compreender a emissão dos memes também como atos concretos de proferimento, que dependem de um contexto para a sua compreensão, esta que também é uma ação dialógica, na qual os receptores interpretam o meme de um modo responsivo, ativo. O pensamento de Bakhtin também se faz presente em nossa pesquisa em um segundo momento, com o conceito de carnavalização, apresentado pelo autor na obra Cultura popular na idade média e no renascimento: o contexto de François Rabelais, do qual partiremos para compreender o cômico na cultura dos memes.

A leitura desses autores, tanto de maneira direta por suas obras, como de seus comentadores, em articulação com outros pensadores, que aparecem de modo menos central na abordagem semiótica pensada para a pesquisa, nos permite, assim, encontrar respostas para as questões que levantamos anteriormente, nos conduzindo ao entendimento do meme como linguagem da internet, caracterizando-o a partir de algumas categorias. Para melhor visualizar como as respostas aos questionamentos que viabilizaram a construção de nosso objeto foram estruturadas, passemos à apresentação dos capítulos dessa dissertação e outras considerações metodológicas. 
No primeiro capítulo, intitulado $O$ meme, revistamos a teoria de Richard Dawkins, revisando brevemente a ideia do egoísmo do gene que fundamentou a formulação de seu conceito de meme, a unidade cultural replicadora. Nesse primeiro momento, apresentamos, assim, algumas analogias entre meme e gene - as noções de disputa, coadaptação, longeividade, fecundidade e fidelidade da cópia - e também algumas críticas com relação a aparente irrelevância da agência humana na reprodução dos memes, a indefinição do que seria a unidade memética e o questionamento acerca da imitação como principal forma de aprendizagem cultural pelos memes. Em seguida, procuraremos vislumbrar algumas aproximações dessa teoria com a semiótica, relacionando a ideia de meme à ideia de signo, buscando também compreender o que faltou a Dawkins para que o seu meme pudesse servir de modelo teórico para entender o fenômeno que se configurou na internet.

O meio internet é assim o assunto de nosso segundo capítulo, nomeado Meio e cultura, no qual buscaremos discutir a relação dessas duas instâncias e a emergência do meme como uma linguagem da internet. Nessa seção, exploraremos a sugestão de McLuhan de que o meio de comunicação pode ser entendido como uma extensão da consciência, ideia ampliada pelo pesquisador Luiz Claudio Martino e que nos permite vislumbrar a web mais que como um suporte material para a transmissão de mensagens, mas sim como um meio de comunicação, isto é, uma função que o suporte adquire ao proporcionar a relação de consciências. Veremos, desse modo, que a relação entre meio e consciência é mais que uma analogia simbólica, uma vez que há uma continuidade ontológica entre os dois, sendo ambos preenchidos por um continuum de signos. Essa discussão nos permitirá compreender o meio de comunicação em diálogo com a noção de semiosfera de Lotman, um ambiente de cultura e, por assim dizer, como veremos, um dispositivo pensante, isto é, um sistema que funciona como uma mente. É nesse espaço, preenchido por formações semióticas diversas que a existência da linguagem se torna possível. Tomada a semiosfera como esse espaço de cultura, revisitaremos mais uma vez Dawkins, mostrando como o conceito de semiosfera se relaciona com o que propunha o etólogo.

No capítulo seguinte, o terceiro, que recebe o título de $O$ meme como linguagem, procuraremos discutir como um meme pode ser entendido como uma linguagem, pensando a partir de três traços desse fenômeno que se implicam, esclarecendo assim os questionamentos que apresentamos anteriormente. O primeiro traço seria o caráter "normativo" do meme, isto é, o fato de ele possuir certa regularidade que conecta de 
algum modo todas as suas manifestação. Também objetivamos ponderar o seu aspecto social, ou seja, de partilha, comunitário, o fato de que, enquanto linguagem, não pertence a um único indivíduo e nem se constitui privadamente. Por fim, também devemos considerar a sua capacidade de dar (novos) sentidos às informações, a possibilidade de se constituir como uma forma de compreender o mundo. Para tanto, nos ancoraremos na filosofia de Peirce, pensando o meme na categoria fenomenológica de terceiridade, que nos permite compreender a sua generalidade como linguagem, isto é suas regras. Em diálogo com esse autor e seu pensamento estará a noção de jogos de linguagem de Wittgenstein, que nos permitirá compreender a emergência da regularidade nos memes, bem como seu aspecto público, social e partilhável. Nesse capítulo, também discutiremos as noções de comunidade e contexto cultural (semiosfera), que sustentam o processo de compreensão dos textos codificados na linguagem do meme, uma compreensão que é responsiva, como nos mostrará Bakhtin. Aqui, pensaremos também tanto geração de réplicas do meme, quanto a compreensão de cada uma delas como uma semiose, incluindo, nesse debate, a possibilidade de um certo grau de incompreensão do meme.

Entendido que o meme, como linguagem, apresenta certa regularidade, no capítulo 4, O meme e seus jogos, iremos avançar nas reflexões e discutir as suas especificidades, entendendo a repetição e a paródia como o que há de geral em todas as ocorrências meméticas. Destacaremos, assim, a tendência que tanto repetição como paródia possuem em suas articulações no meme de conduzir algo a sair de sua normalidade, trabalhando sempre nos limites de um sistema dado. Estão relacionadas à paródia e à repetição também, algumas categorias que definimos como secundárias que caracterizam as réplicas dos memes. São elas: o excesso, o exagero, o absurdo e $o$ humor, esta última discutiremos com mais detalhes em oposição ao cômico. Neste capítulo, compreenderemos ainda o riso como uma forma de conceber o mundo que é possível pela linguagem do meme. Para tanto, pensaremos a partir do conceito de carnavalização de Bakhtin do qual falamos nesta introdução, vislumbrando a cosmovisão carnavalesca como um método de ressignificação das informações.

Por fim, acrescentamos algumas considerações sobre nossas escolhas terminológicas e sobre a seleção dos memes presentes nesta dissertação. Quanto aos termos, optamos por utilizar "meme" no singular quando nos referimos ao fenômeno entendido como linguagem, isto é, "o meme" designando uma forma de compreender o mundo que envolve paródia e repetição, a definição que abrange as diferentes 
manifestações da internet, que por vezes também nos referimos como a "linguagem do meme". Já o termo no plural, "memes", e também nas formas "um meme" ou "o meme", referindo-se a uma manifestação individual, concerne o que também chamamos de "ocorrência memética", isto é, uma série de textos que formam o conjunto de um meme. Definimos também que cada unidade desse conjunto será chamada de "réplica", ou seja, uma réplica de um meme é um dos elementos que compõe uma ocorrência memética. Essas decisões terminológicas podem ser visualizadas na Figura 1, a seguir.

Figura 1 - Réplica e ocorrência memética

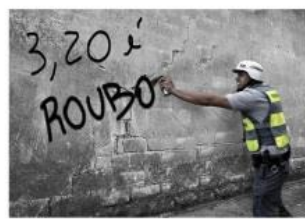

Réplica 1

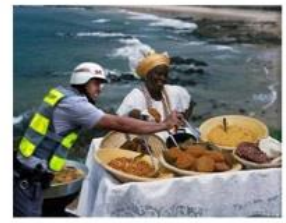

Réplica 2

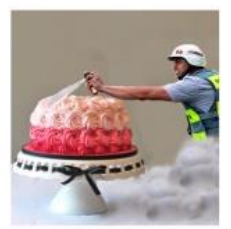

Réplica 3

Meme (ou ocorrência memética) Polícia pacifica

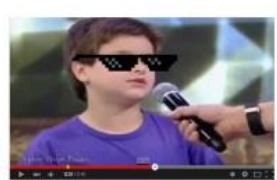

Réplica 1

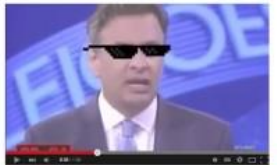

Réplica 2

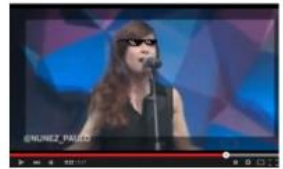

Réplica 3

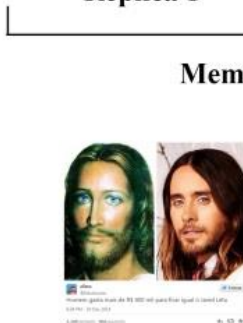

Réplica 1

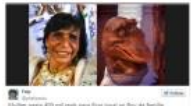

Réplica 2

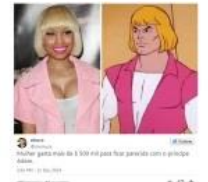

Réplica 3

Meme (ou ocorrência memética) Gasta mais de 400 mil

Fontes das imagens: policiapacifica.tumblr.com ${ }^{12}$, youtube.com ${ }^{13}$, www.youpix.com.br ${ }^{14}$

Dado o grande volume de ocorrências meméticas existentes, para fins deste trabalho, também estabelecemos alguns critérios para a seleção dos memes que aparecerão nesta pesquisa. Nossa escolha norteia-se basicamente pela adequação das imagens para ilustrar o que está sendo elucidado no texto no momento em que aparecem. Procuramos, assim, variar entre os exemplos, apresentando memes que são

\footnotetext{
$12<$ policiapacifica.tumblr.com> Acesso em 26/1/2015

${ }^{13}$ Réplica 1: 〈https://www.youtube.com/watch?v=Gnb2IG9YriI>;

Réplica 2:<https://www.youtube.com/watch?v=cPvyJc7ApYA $>$;

Réplica 3: <https://www.youtube.com/watch?v=rYtYTZobqPY> Acesso em 26/1/2015

${ }^{14}<$ http://youpix.virgula.uol.com.br/memepedia/mirou-na-kim-kardashian-acertou-no-meme/\#more-155051 >

Acesso em 26/1/2015
} 
foto-montagens, foto-legendas, vídeos, frases (tweets), entre outros, para mostrar a variedade formal da qual paródia e repetição emergem, configurando o que entendemos como meme. Buscamos incluir na pesquisa também ocorrências tanto de origem brasileira, como de origem norte americana (muitas das quais também ficaram conhecidas no Brasil). Nesse sentido, baseamos nossas escolhas em nosso repertório, procurando confirmar o entendimento delas como meme pautando-nos em dois sites que funcionam como repositório de memes, o norte americano Know Your Meme, que mencionamos anteriormente, e o brasileiro youPIX ${ }^{15}$. Ambos nos serviram, assim, como uma maneira de averiguar que manifestações são tomadas no senso comum como meme, para em seguida passar pela nossa avaliação e proposta de compreensão.

Postas essas questões e considerações iniciais, passemos à compreensão do meme como uma linguagem da internet, observando suas especificidades e modos de dar sentido ao mundo.

15 "O youPIX é uma plataforma que celebra, discute e é palco para a cultura de internet, dando espaço e voz para os agentes da revolução silenciosa que acontece através dos fios de rede e já mudou um sem número de aspectos da cultura, comportamento, negócios e da comunicação do mundo" (texto publicado no site). Assim como o knowyourmeme.com, o youPIX possui uma "memepedia" que explica a origem e o desenvolvimento de memes brasileiros. 


\section{CAPÍTULO 1. O MEME}

"Quando morremos há duas coisas que podemos deixar para trás: os genes e os memes". Richard Dawkins

Este capítulo tem como objetivo explorar o conceito do termo "meme", cunhado por Richard Dawkins em 1976, adotado nas últimas décadas para determinar o fenômeno comunicacional da internet tema desta pesquisa.

No percurso desta investigação e na busca de estabelecer uma discussão conceitual que pudesse fundamentar uma noção de meme da internet, partimos de uma pesquisa da gênese do termo, procurando determinar que relações esse conceito original estabelecia com o que estava tomando forma na internet. Ou seja, preliminarmente intencionávamos compreender por que um conjunto de manifestações na web estava sendo nomeado como tal.

Nesse sentido, em um primeiro momento, definindo a concepção de meme de maneira simples e direta, podemos afirmar que a explicação de Dawkins elucida o fenômeno que se configurou na web por conceber o meme como algo (uma ideia ou uma informação) que se replica no tempo e no espaço. Ao pormenorizar seu conceito, no entanto, verificamos que essa compreensão não se sustentava por completo para o entendimento da dimensão semiótica do fenômeno, contudo as articulações feitas pelo etólogo e seus seguidores, bem como as críticas suscitadas por suas concatenações nos provocaram certas inquietações que ensejaram a problematização do tema, articulando assim nossa apreensão dessas manifestações culturais na web, objeto desta pesquisa.

No presente texto, visamos apresentar, portanto, a formulação teórica do devir da cultura a partir do conceito de meme de Richard Dawkins, bem como o desenvolvimento desse construto por outros autores que deram continuidade aos seus estudos, fundando um campo de conhecimento controverso, a memética. Nessa perquirição, incluímos algumas críticas feitas ao modelo proposto por essa dita ciência, bem como procuramos potencialidades e provocações na formulação de Dawkins para a nossa compreensão das manifestações culturais da internet enquanto uma linguagem. 


\subsection{O meme de Richard Dawkins}

No escopo das ciências biológicas, as teorias consideradas neodarwinistas, isto é, que remontam às ideias de Charles Darwin acerca da evolução das espécies, se dividem em duas perspectivas no que tange a forma como encararam a hipótese da seleção natural: sob a ótica do gene ou sob a ótica do indivíduo, de modo que ambas as visões referem-se ao mesmo neodarwinismo. O etólogo Richard Dawkins, como fica claro no título de sua obra mais célebre, "Gene Egoísta” (2007), optou pela perspectiva genética, fundada na teoria que leva o mesmo nome do livro e que lhe facultou formular posteriormente o conceito de meme, uma noção da cultura e da maneira como o homem transmite informações, carregada de uma visão biológica.

O cerne da teoria do egoísmo dos genes parte do pressuposto de que nós, os seres vivos, somos máquinas criadas por eles, somos um mecanismo complexo projetado para a sua sobrevivência. Assim, graças a nós, as máquinas, essas unidades genéticas foram capazes de sobreviver em um mundo competitivo por anos, capacidade essa que Dawkins atribui a uma qualidade que ele sustenta ser predominante nos genes: o egoísmo. Nesse sentido, ainda que os genes cultivem, em algumas circunstâncias especiais, certa forma limitada de altruísmo, no fim, suas ações são realizadas para que eles consigam atingir seus objetivos egoístas. Por conseguinte, segundo Dawkins, a noção de que os seres vivos evoluem agindo "pelo bem da espécie" ou "pelo bem do grupo" é uma noção falsa, pois "a unidade fundamental da seleção, e, portanto, do interesse próprio, não é a espécie, nem o grupo e, tampouco, num sentido estrito, o indivíduo, e sim o gene, a unidade da hereditariedade" (DAWKINS, 2007, p. 52).

A relação dos genes com suas máquinas de sobrevivência, no entanto, não é de controle absoluto. Eles podem reger o comportamento delas indiretamente, preparandoas de antemão, “depois disso, elas ficarão por sua própria conta, e só restará aos genes acomodar-se passivamente em seu interior" (ibidem, p. 117). Logo, os genes não nos instruem com detalhes específicos que garantiriam sua sobrevivência, mas sim com estratégias e artimanhas gerais de como lidar com o mundo. Desse modo, os indivíduos dotados de cérebro, que adquiriram a capacidade de prever o futuro e agir de acordo com essa previsão, podem até mesmo se rebelar contra as "regras" colocadas pelos genes, por exemplo, recusar-se a ter quantos filhos puder, uma estratégia que seria excelente para a longevidade e fecundidade genética, uma vez que ter muitos descendentes favorece a perpetuação e propagação dos genes, mas que pode ser gerida e 
negada pela máquina de sobrevivência. As escolhas feitas por elas dependem de uma série de fatores, assim, "aqueles indivíduos cujos genes constroem cérebros de tal forma que eles tendem a efetuar as apostas corretas contarão, como consequência direta, com maiores probabilidades de sobreviver e, portanto, de propagar esses mesmos genes" (ibidem, p. 122).

A partir dessa breve revisão da hipótese do gene egoísta, podemos compreendêlo como uma unidade de hereditariedade que atua como se tivesse um comportamento egocêntrico visando à própria perpetuação e devendo a sua sobrevivência à passagem em sucessivos e numerosos corpos individuais. Nesse caso, a seleção natural resulta, na verdade, de uma competição entre genes e não entre indivíduos ou espécies. A teoria de Dawkins, cuja motivação para formulação foram más interpretações da teoria de Darwin (ibidem, p. 9), revolucionou, portanto, ao resolver alguns impasses apresentados por outros autores, como em casos de egoísmo e altruísmo em diversas espécies que sugeriam uma disputa ora pelo bem do indivíduo e de seu material genético, ora pelo bem da espécie ou grupo. Dentro da perspectiva do egoísmo do gene, questões como essa estariam solucionadas, pois essas unidades superariam que obstáculo fosse para garantir sua perpetuação, inclusive a eliminação do próprio indivíduo (FONTANELLA, 2009b, p. 3).

Essa nova mirada sobre o gene serviu de olhar para o devir da cultura, culminando no que Dawkins conceituou como meme, um replicador análogo ao gene, que nos permite entender a transmissão cultural e a transmissão genética de maneira paralela. O etólogo chegou a essa analogia entre os tipos de transmissão partindo de uma inquietação que surgiu ao observar o trabalho de colegas, darwinistas entusiastas assim como ele, que se dedicaram a encontrar "vantagens biológicas" nas mais diversas qualidades inerentes à civilização humana. Para ele, as ideias destes cientistas, apesar de serem até certo ponto plausíveis, não davam conta do desafio de explicar a cultura, sua evolução e diversidade, e, partindo deste incômodo, apresentou a hipótese da existência de outro replicador: "para compreender a evolução do homem moderno, devemos começar por abandonar a ideia do gene como a única base das nossas ideias a respeito da evolução" (DAWKINS, 2007, p. 328).

Assim, ao considerar que a cultura também evoluía, Dawkins supôs que ela apresentaria algo que pudesse ser comparado ao processo de seleção natural, uma dinâmica análoga que pressuporia a existência de uma unidade replicadora, semelhante ao gene na natureza: 
O novo caldo é o caldo da cultura humana. Precisamos de um nome para o novo replicador, um nome que transmita a ideia de uma unidade de transmissão cultural, ou uma unidade de imitação. "Mimeme" provém de uma raiz grega adequada, mas eu procuro uma palavra mais curta que soe mais ou menos como "gene". Espero que meus amigos classicistas me perdoem se abreviar mimeme para meme. Se isso servir de consolo, podemos pensar, alternativamente, que a palavra "meme" guarda relação com "memória", ou com a palavra francesa même. Devemos pronunciá-la de forma a rimar com “creme". (DAWKINS, 2007, p. 330)

Como exemplos de memes, o autor cita "melodias, ideias, slogans, as modas no vestuário, as maneiras de fazer potes ou de construir arcos" (idem), essas unidades replicadoras seriam, portanto, produtos, hábitos e comportamentos submersos nesse chamado "caldo cultural". A hipótese sustentada pela analogia genética diz ainda que, assim como os genes que se propagam de corpo para corpo no processo de reprodução dos seres vivos, os memes proliferam-se saltando de cérebro para cérebro por meio de uma prática que Dawkins afirma poder ser chamada, em um sentido amplo, de imitação (idem). Desse modo, "toda a cultura, todos os comportamentos sociais, todas as ideias e teorias, todo comportamento não geneticamente determinado, tudo que uma pessoa é capaz de imitar ou aprender com uma outra pessoa é um meme” (TOLEDO, 2009, p. 151).

Nesse sentido, o meme, assim como o gene, se conforma como uma unidade replicadora que objetiva a sua sobrevivência ao longo do tempo, em seu caso, no decorrer da história da humanidade. Para alcançar sua perpetuação, os memes também são dotados de algumas estratégias e qualidades que os colocam em situação de vantagem em relação a outros memes no caldo cultural, aspectos esses que também podem ser explicados pela analogia entre meme e gene.

\subsection{Analogias entre meme e gene}

Dando continuidade, portanto, às similitudes entre a evolução memética e a evolução genética estabelecidas por Dawkins, passemos a mais algumas características dos memes concebidas a partir do entendimento do "estratagema de sobrevivência" dos genes. Para começar, retomemos o processo de transmissão e armazenamento.

De maneira similar à forma como os genes utilizam nossos corpos como máquinas de sobrevivência, os memes utilizam nossos cérebros como seus veículos. Além dos cérebros, eles também se abrigam em outros tipos de suporte (MATOS, 2008, 
p. 47; BLACKMORE, 1999, p. 65-66), como computadores, livros, placas, roupas etc., logo, pode-se considerar como veículo para os memes não só o ser humano, mas qualquer aparato que seja capaz de acolher e transportar um meme ${ }^{16}$. No entanto, o espaço existente nos veículos, tanto nos nossos cérebros quanto nos "veículos inanimados", é limitado, revelando assim mais uma analogia entre memes e genes: a disputa. Memes competem entre si pela nossa atenção e memória, bem como por espaços no rádio, na TV, nas linhas dos jornais, nas estantes da biblioteca, entre outros suportes (DAWKINS, 2007, p. 337).

Portanto, para um meme sobreviver neste ambiente aparentemente desafiador que é a cultura, às vezes, faz-se necessário submeter-se a certas estratégias, conquistando mais facilmente atenção e espaço nos veículos. Assim, alguns deles conjugam-se com outros memes, configurando estruturas de coadaptação, i.e., um "conjunto estável” (ibidem, p. 338) que corrobora para a sobrevivência de todos os memes participantes, o que Speel abreviou para "memeplexos" (SPEEL apud BLACKMORE, 1999, p. 19), complexo de memes coadaptados. Dawkins ilustra esses grupos citando a religião, um memeplexo que engloba memes tais como a arquitetura, os rituais, a fé, a música, os dogmas, entre outros (DAWKINS, 2007, p. 338-339), ideia que também é desenvolvida por Blackmore na obra The Meme Machine ${ }^{17}$.

Além da coadaptação, outra analogia desenhada por Richard Dawkins, desenvolvida por seus seguidores e que aparece em diversos trabalhos pesquisados para essa investigação, são as três qualidades inerentes aos genes, que também se configuram como características do meme: longevidade, fecundidade e fidelidade. Como mencionamos anteriormente, os memes replicam-se por meio da imitação, no entanto, assim como os genes, nem todos que são passíveis de replicação serão memes bemsucedidos (ibidem, p. 333). Nesse sentido, para obter um grau elevado de sobrevivência, além de explorar as oportunidades de associação com outras unidades meméticas, os memes devem possuir essas três características que lhes dão o status de memes exitosos.

A primeira delas, a longevidade, diz respeito à capacidade do meme de permanecer no tempo (RECUERO, 2006, p. 3). Assim, tomando como exemplo a religião, tema recorrentemente discutido entre os que adotaram essa visão evolucionista

\footnotetext{
${ }^{16}$ No próximo capítulo, em uma perspectiva semiótica, veremos que esse aspecto do meme de Dawkins se explica pelo caráter de externalidade da mente abordado por Peirce e também entendido por Wittgenstein.

17 BLACKMORE, Susan. Religions as memeplexes. In: The Meme Machine. Oxford: Oxford University Press, 1999, p.187-203.
} 
da cultura, podemos dizer que Jesus é um meme longevo, pois há pelo menos 2014 anos, a ideia do que seria Jesus vem sendo replicada inúmeras vezes e se espalhando de cérebro em cérebro (utilizando aqui os termos de Dawkins) entre a população cristã mundial.

Já a fecundidade é relativa à capacidade de difusão de um meme, isto é, a possibilidade de propagação ocupando espaços em veículos, quer sejam nossos cérebros ou qualquer outro suporte, como foi exposto anteriormente. Um alto grau de fecundidade não necessariamente implica um alto grau de longevidade. Dawkins menciona que há memes que atingem um sucesso brilhante em um curto período, espalhando-se de maneira veloz, porém não sobrevivem em longo prazo no pool de memes (DAWKINS, 2007, p. 334). Por exemplo, uma música extremamente popular, mas que tem um sucesso passageiro, é apenas uma moda, se configura como um meme de alta fecundidade, porém baixa longevidade.

Por fim, temos a fidelidade, que se refere à capacidade do meme ou do gene de gerarem réplicas mais similares possíveis à unidade memética ou genética original. Dawkins também usa a expressão fidelidade da cópia (ibidem, p.334). A seu ver, à primeira vista, os memes não são replicadores de alta fidelidade. Ele ilustra esta crença com uma situação: a transmissão de ideias de um cientista para determinado público. Ele assevera que ao falar de uma teoria de outro autor, como ele faz no livro, essa retransmissão provavelmente modifica em algum grau o que foi dito originalmente. Dessa forma, a passagem de um meme de um cérebro a outro diverge um pouco da transmissão "tudo ou nada" dos genes, "a transmissão do meme parece estar sujeita à mutação e à mistura contínuas" (idem), pois espera-se que o intelecto não só memorize, como tenha a capacidade de originar uma replicação diferenciada do meme recebido (MATOS, 2008, p. 48). No entanto, apesar ser mais provável de ocorrer nos memes, a modificação não necessariamente acontece de forma radical. Segundo Matos, há memes tão "nítidos e distintamente identificáveis", com uma fidelidade intrínseca a eles, nos quais qualquer alteração poderia torná-los outro meme. Ele exemplifica afirmando que é o caso de um poema, provérbio ou uma melodia, mas que não é o caso de uma teoria, de um julgamento de valor, entre outros memes (ibidem, p. 48-49).

Ao observar os memes citados por Matos para ilustrar situações de fidelidade inerente (poemas, provérbios, melodias), a questão da fidelidade da cópia nos parece problemática. Se imaginarmos, por exemplo, o poema "Canção do Exílio" de Gonçalves Dias e sua versão alterada paródica de Oswald de Andrade ou de Mário Quintana, não 
temos exatamente o mesmo poema, no entanto, por ser uma paródia, e por isto abrigar a complexidade do encontro entre dois textos (PAYANT apud HUTCHEON, 1985, p. 24), não poderíamos entender as novas versões ainda como réplicas do meme "Canção do Exílio"?

Ainda que Dawkins afirme não ter a intenção de propor uma ampla teoria da cultura $^{18}$, a analogia que ele fez pareceu interessante e coerente para alguns filósofos e pesquisadores, o que acabou suscitando uma ciência controversa, a memética. Mesmo sendo questionável enquanto uma disciplina válida para entender a cultura (SPERBER, 2000, p. 172; BLOCH apud FONTANELLA, 2009b, p. 6), esse conjunto de conhecimentos angariou seguidores que deram continuidade às ideias presentes no "Gene Egoísta" a respeito da unidade replicadora cultural, bem como desencadeou diversos questionamentos críticos quanto à forma como propõe compreender a relação do homem com a cultura. Vejamos a seguir alguns dos pontos levantados nessas ponderações e o que podemos discutir a partir delas.

\subsection{Críticas à memética}

O que contestamos anteriormente acerca da fidelidade da cópia é apenas uma das inquietações que integra um conjunto de críticas a respeito das reflexões da memética a partir da analogia meme e gene. Outra que destacamos refere-se a um incômodo indelével de alguns pensadores com a aparente indiferença desse campo de conhecimento em buscar compreender a cognição e a ação do indivíduo nos processos de transmissão cultural.

A analogia de Dawkins toma os memes como se eles fossem dotados de certa independência e egoísmo, buscando no ambiente e em seus veículos estratégias de sobrevivência na cultura, o que fica claro na fala um tanto exagerada de Susan Blackmore: "Imagine um mundo cheio de cérebros e muito mais memes do que casas possíveis para eles. Os memes estão sempre tentando ser, 'tentando', com aspas, isto é uma abreviação para 'se eles puderem ser copiados, serão'. Estão usando vocês e eu como suas máquinas propagadoras, maquinaria de cópias, e nós somos as máquinas dos

\footnotetext{
18 "Não tenho certeza se o meio da cultura humana reúne de fato as condições necessárias para manter em funcionamento uma forma de darwinismo. Mas em todo caso trata-se de uma questão secundária para mim. Considerarei que o capítulo 11 [Memes: os novos replicadores] alcançou seu objetivo se o leitor fechar este livro com a sensação de que as moléculas de DNA não são as únicas entidades que podem constituir a base da evolução darwiniana. $\mathrm{O}$ meu propósito era reduzir o gene à sua própria medida, e não esculpir uma teoria grandiosa sobre a cultura humana” (DAWKINS, 2007, p. 506).
} 
memes" (BLACKMORE, 2008, tradução nossa ${ }^{19}$ ). Afirmações como essas podem nos fazer questionar o papel da agência humana na dinâmica da cultura e na transmissão de memes, e, como sinalizado por Giddens, oferecem "o risco constante de minimizar a capacidade do indivíduo de criar diferença no curso de eventos" (GIDDENS apud FONTANELLA, 2009b, p. 7). É importante ressaltar, no entanto, que Dawkins deixa clara a sua intenção de produzir uma metáfora, a partir da qual genes e memes não devem ser pensados como agentes conscientes dotados de propósitos (DAWKINS, 2007, p. 336) e que temos controle da situação, pois podemos nos rebelar contra os ditames dos replicadores egoístas (ibidem, p. 343). Deve-se ter em mente, portanto, que trata-se de um recurso discursivo e "não há nada de nocivo, enganoso ou filosoficamente equivocado nas atribuições como-se metafóricas. O único engano é tomá-las literalmente” (SEARLE, 1997, p. 122).

A "grande novidade" da memética seria, portanto, introduzir uma noção de cultura a partir de um recorte neodarwinista no qual se reconhece as ações conscientes humanas $^{20}$, como o próprio Richard Dawkins o faz, mas opta-se por focar no meme como uma unidade replicadora que permite a evolução da cultura, isto é, a memética escolheu trabalhar sob a ótica do meme e não do indivíduo. Em vista da perspectiva evolucionista que inspira essa ciência, devemos ter em conta que a memética compreende o devir da cultura como um processo de constante adaptação às mudanças do ambiente, nos quais as unidades replicadoras obtêm como resultado sua perpetuação no curso do tempo. Desse modo, o ambiente dos memes, no caso, somos nós, são às nossas mentes que eles devem se adaptar:

[...] um meme não nos domina ignorando as nossas capacidades cognitivas: ele "nos domina" por causa de tais capacidades! Se não tivéssemos predileção por determinados memes, todos os memes teriam a mesma chance de se multiplicar. Não haveria seleção e, consequentemente, não haveria evolução. (TOLEDO, 2013, p. 196)

\footnotetext{
19 "Imagine a world full of brains and far more memes than can possibly find homes. Memes are all trying to get copied, 'trying', in inverted commas, that's the shorthand for 'if they can get copied, they will'. They are using you and me as their propagating, copying machinery, and we are the meme machines". Fala de Susan Blackmore em palestra no TED (Technology, Entertainment, Design), disponível em <http://www.ted.com/talks/susan_blackmore_on_memes_and_temes.html> Acesso em 26/1/2014.

${ }^{20}$ Como mais um exemplo de autores que admitem a agência humana no caldo cultural permeado pelos memes, podemos citar a autora Kate Distin, que também se dedicou ao estudo dessas unidades culturais e que reconhece que os memes podem ter suas mutações determinadas por decisões humanas conscientes. Segundo ela, os memes lembrados com maior facilidade são aqueles que constituem ideias novas, que são melhor absorvidos em uma rede de ideias aceitas já existente ou aqueles que são úteis em determinado contexto (DISTIN apud FONTANELLA, 2009, p. 5).
} 
Nesse sentido, acreditamos que não é o caso de a memética "conceder" total controle aos memes, mas sim de ela estar mais preocupada em entender a sobrevivência dos comportamentos, gestos e informações. Para tanto, seus autores optaram por uma abordagem que, ainda que controversa e discutível, está focada nos próprios comportamentos, gestos e informações e não em quem os produz, muito menos com que intenção.

Destacamos também que até aqui empregamos termos variados (de conceitos distintos) para buscar definir o meme e para nos referirmos a ele, tais como "comportamentos", "hábitos", "gestos", "informação" e "ideias". Essa variedade de possibilidades do que seria um meme também acabou tornando-se alvo de crítica, por exemplo, por Fontanella, que questiona o que seria uma unidade de informação em um meme, dando o exemplo de uma piada de papagaio, sobre a qual indaga, "o que seria o meme? A piada em si, o uso de papagaios, a prática de contar piadas?" (FONTANELLA, 2009b, p. 6). De acordo com o autor, hesitações como essa provêm de uma falta de consenso na compreensão dos memes dentro da própria memética.

Ao conceber a unidade cultural a partir dos três principais autores, temos Richard Dawkins e Daniel Dennett que entendem o meme como informação e Susan Blackmore que refere-se a ele como instrução (TOLEDO, 2009, p. 141). Por essa imprecisão, cada análise que explica algum traço ou elemento cultural decide por entender o meme ou como uma informação que se repete ou como um comportamento. Assim, também é essencial levar em consideração, para determinação da unidade cultural, a maneira como ela é transmitida, uma noção menos divergente entre os autores citados: tanto Richard Dawkins quanto Susan Blackmore, por exemplo, afirmam que os memes se replicam por imitação. Dawkins, no entanto, entende a imitação em um sentido amplo, incluindo outras formas de aprendizagem, e Blackmore em um sentido estrito, isto é, por meio da cópia de comportamentos (ibidem, p. 142). No entanto, mais uma vez, devemos ter cuidado ao nos prendermos à imitação como elemento definidor da unidade replicadora, pois essa noção também foi motivo de objeção.

A ideia de que a imitação é o processo que permite que as unidades culturais transitem de cérebro para cérebro é também uma noção a ser reavaliada. Essa maneira de compreender a transmissão cultural levanta uma discussão a respeito dos nossos processos de aprendizagem e traz à tona uma reflexão acerca da cognição. Para entender 
essa objeção, retomamos rapidamente o exemplo exposto por Dawkins no prefácio do livro de Susan Blackmore The Meme Machine.

Procurando esclarecer como um meme pode replicar-se com alta fidelidade, de modo quase genético, Dawkins propõe um experimento hipotético, no qual apresenta duas situações. Na primeira, temos um grupo de vinte crianças. Uma delas recebe um desenho de um junco chinês (um barco) e é pedido que ela o desenhe. Em seguida, o desenho da primeira criança é entregue a uma segunda, que deve reproduzi-lo. $O$ desenho da segunda criança é passado a uma terceira de forma que ao final temos 20 desenhos feitos como em uma brincadeira de telefone sem fio. Dawkins não chegou a realizar o experimento, mas imagina que o primeiro desenho será muito diferente do vigésimo, que terá um alto grau de mutabilidade se comparado com a imagem inicial que foi apresentada à primeira criança.

Na segunda situação, ao invés de pedir para que a primeira criança faça um desenho, ela será ensinada, por demonstração, a fazer um origami do junco chinês. Em seguida, ensinará a segunda criança, que ensinará a terceira e assim por diante. Dawkins propõe que esse experimento seja repetido inúmeras vezes e presume que, nas primeiras vezes, é possível que os barcos não se pareçam em nada uns com os outros, mas com a repetição do experimento, o último conjunto de barcos produzidos será mais uniforme. Isso será possível porque, mesmo que uma criança cometa um deslize em uma das dobraduras, não necessariamente esse erro vai ser passado adiante, pois ao longo da "linha de produção de barquinhos" pode haver uma criança mais habilidosa que corrigirá o erro da criança anterior ao fazer o próprio junco chinês. No final, provavelmente alguns barcos estarão mais bem feitos que outros, mas as imperfeições não serão copiadas ao longo do processo (DAWKINS, 1999, x-xi).

Dawkins conclui com esse experimento hipotético que na primeira situação temos um caso de "cópia do produto" (nos termos de Susan Blackmore), no qual o fenótipo $^{21}$ de cada geração corresponde ao genótipo. Já a segunda situação consiste em uma transmissão do tipo "cópia da instrução", seja por demonstração ou passado verbalmente, na qual o fenótipo não é transmitido. Dawkins reconhece, assim, que este seria um caso no qual a replicação de um meme estaria mais próxima de uma replicação genética (ibidem, xi).

21 O fenótipo é o conjunto de características observáveis num organismo, ou ainda, o conjunto de características que constituem a manifestação de um genótipo (Priberam Dicionário Online). Disponível em: <http://www.priberam.pt/dlpo/fen\%C3\%B3tipo> Acesso 29/1/2014. 
Voltando às críticas à memética, no que consistiria então a inquietação com relação ao processo de imitação a partir desses exemplos? Um argumento exposto por Dan Sperber e por Deirdre Wilson mostra que em ambos os casos não se trata de um processo puro e simples de imitação:

As instruções não estão sendo copiadas, em nenhum sentido útil do termo, de um participante ao outro. Certamente, as instruções não podem ser imitadas, uma vez que somente o que pode ser percebido pode ser imitado. Quando são dados implicitamente, as instruções têm de ser inferidas. Quando são dadas verbalmente, as instruções devem ser compreendidas, um processo que envolve uma mistura de decodificação e inferência. (SPERBER e WILSON apud SPERBER, 2000, p. 171, tradução nossa ${ }^{22}$ )

Talvez, a partir dessa crítica, possamos deduzir o porquê de Dawkins ter sido mais cuidadoso ao dizer que a imitação deve ser entendida "em um sentido amplo", ao contrário de Susan Blackmore que preferiu entender a imitação em um sentido estrito (TOLEDO, 2009, p. 142). A análise de Sperber e Wilson nos mostra, portanto, que a aprendizagem cultural não é somente uma questão de imitar, seja um produto, sejam instruções, e sim um processo bem mais complexo, no sentido de envolver deduções e inferências. Em todo caso, das leituras feitas para essa investigação, não identificamos uma explicação mais detalhada do que seria esse "sentido amplo" de entender a imitação que Dawkins aponta e, pelo exemplo dado por ele na obra de Blackmore, a crítica de Sperber nos parece bastante válida. Possivelmente precisaríamos de mais leituras para nos certificar do que Dawkins quis se referir, mas nosso objetivo aqui não é nos aprofundar na memética e sim aduzir alguns conceitos e críticas, tirando delas o que nos permita compreender os memes da internet.

Quanto a sua firmação enquanto disciplina, a memética parece ainda engatinhar em bases não muito sólidas. A metáfora proposta por Dawkins, que é a princípio atraente, nos permite entender uns e outros exemplos de transmissão de traços e comportamentos culturais, mas parece limitar-se aos exemplos e à busca em "encaixar" fenômenos na analogia entre gene e meme. Para que a memética se sustente, a teoria que ela sugere, fundada na analogia e na ideia de êxito das cópias, deveria ser essencial para dar forma à maioria dos conteúdos da cultura (SPERBER, 2000, p. 172) e não limitar-se a alguns poucos casos dos quais os críticos encontram inúmeras brechas e propõem contraexemplos com aparente facilidade. Um artigo publicado no

\footnotetext{
22 "The instructions are not being "copied" in any useful sense of them term from one participant to the next. Certainly, instructions cannot be imitated, since only what can be perceived can be imitated. When they are given implicitly, instructions must be inferred. When they are given verbally, instructions must be comprehended, a process that involves a mix of decoding and inference."
} 
encerramento do Journal of Memetics conclui o tópico da série de inquietações com a memética que discutimos expondo um incômodo que pode resumir, junto com a queda na qualidade das submissões, o término da publicação do periódico: "O fato é que quanto mais próximo do núcleo da memética um trabalho tem estado, menos bemsucedido ele tem sido. O cerne, a analogia meme-gene, não tem se mostrado um manancial de modelos e estudos que tenham proporcionado uma 'alavancagem explicativa' sobre o fenômeno observado" (EDMONDS, 2005, tradução nossa ${ }^{23}$ ).

\subsection{Provocações e aproximações: o meme da memética e o meme da internet}

Não obstante as críticas recebidas, especialmente a de uma falta de cientificidade desse conjunto de conhecimentos, devemos reconhecer certo valor heurístico da memética, que nos proporciona uma reflexão acerca dos traços de nossa cultura em uma perspectiva diferente, ainda que, segundo Toledo (2013, p.196), suas analogias não provem nem demonstrem empiricamente nada. Não intencionamos, portanto, entrar em uma discussão da "utilidade" dessa ciência, mas reconhecer sua validade enquanto um exercício filosófico e, como dito anteriormente, que nos serviu de provocação para pensar os memes da internet.

No início de nossa investigação e leituras, não muito diferente dos críticos, o nosso primeiro incômodo com memética também consistiu na abordagem que tratava de uma aparente passividade do sujeito no processo de transmissão cultural. Não haveria uma ação intencional e consciente do dono desse cérebro que apenas replica a dita unidade de informação? Essa questão, como vimos, foi respondida por Toledo ao mostrar que nossa mente é o ambiente ao qual os memes devem se adaptar, sobrevivendo aqueles que, graças às escolhas do sujeito, conseguem ser passados adiante (idem). A construção da memética dos fenômenos de cultura, contudo, por sua opção de perspectiva (o ponto de vista dos memes), mesmo reconhecendo essa intencionalidade do sujeito de propagar e o seu favoritismo por alguns memes (seleção), ignora a compreensão por parte desse sujeito do que lhe é "transmitido" e o que ele "transmite". Nesse sentido, a memética nos serviu de provocação, pois apreender o

\footnotetext{
23 "The fact is that the closer work has been to the core of memetics, the less successful it has been. The central core, the meme-gene analogy, has not been a wellspring of models and studies which have provided "explanatory leverage" upon observed phenomena."
} 
entendimento de um artefato cultural nos parecia essencial para abordar um fenômeno que se insere em um ambiente comunicacional.

Desse modo, destacamos uma distinção que não ficou muito clara nessa breve leitura que fizemos da memética, e que justifica o desenvolvimento da crítica à falta da agência humana, que seria uma diferenciação entre os termos "cérebro" e "mente". Quando Dawkins inicialmente postula seu conceito de meme ele aduz que a proliferação dessas ideias se daria por sua passagem de cérebro para cérebro e não de mente para mente. Não estamos afirmando que Dawkins não reconheça que tenhamos mente, pois no "Gene Egoísta", por exemplo, ele afirma que a evolução da capacidade dos seres vivos de simular situações "parece ter culminado na consciência subjetiva" (DAWKINS, 2007, p. 127), mas em sua abordagem das unidades culturais replicadoras e do que tivemos oportunidade de analisar de outros memeticistas, a forma como está argumentada a hipótese dos memes e o uso de termos como cérebro e transmissão cultural acabam implicando, de certa maneira, a posição do sujeito como um simples vetor de memes e não como alguém que experimenta e compreende o mundo por meio de sua cultura, sendo, talvez, uma consequência da escolha da abordagem na perspectiva do meme.

O incômodo com a aparente passividade dos sujeitos nos fez questionar também como a memética entenderia a relação entre esses sujeitos pelos memes. Ao que parece, os memeticistas não ignoram o fato de que a cultura pressupõe $o$ outro, não sendo assim algo que acontece na individualidade. Tanto é que a memética, entendida como uma teoria parte do darwinismo universal ${ }^{24}$, admite, por exemplo, as ideias de hereditariedade e competição, conceitos dos quais depreende-se a existência de um segundo sujeito. Contudo, mais uma vez, por não estar focada na compreensão que esses sujeitos fazem dessas unidades replicadoras, isto é, o que significam esses memes em uma comunidade de indivíduos, não há uma explicação da relação que os indivíduos estabelecem por meio dessas unidades culturais para além de ambientes aos quais elas têm de se adaptar. Não encontramos na memética elucidações mais detalhadas que justificariam uma ideia de coesão social e partilha de sentidos por meio da cultura, por

\footnotetext{
${ }^{24} \mathrm{O}$ darwinismo universal pode ser entendido como um argumento lógico, isto é, uma forma de construir o pensamento, baseado nas ideias de seleção natural e evolução primeiramente propostas por Darwin, não sendo necessariamente aplicado à biologia. Entre as condições necessárias para ocorrer qualquer processo de evolução por seleção natural estão: "reprodução com herdabilidade, variação intraespecífica, possibilidade do surgimento de novas mutações, aptidão diferencial, falta de recurso para a reprodução, tempo para o processo ocorrer" (TOLEDO, 2013, p. 190).
} 
exemplo. Aparentemente a preocupação da memética é a transmissão e a sobrevivência das informações culturais.

Apesar das críticas a algumas hipóteses dessa disciplina, acreditamos que a analogia meme e gene é frutífera para entender a cultura como algo que ultrapassa o limite temporal da nossa existência. Longe de ignorar a essencialidade da agência humana que alguns autores (por exemplo, FONTANELLA, 2009b; MORAIN, 2009) tanto ressaltam ser um equívoco da memética, devemos reconhecer que essas unidades culturais (se quisermos segmentar a cultura em unidades, como faz a memética), de certa maneira, possuem "vida própria". O que queremos dizer com isso é que, se podemos entender o meme como um signo (e a ideia de signo inclui a intelecção humana ${ }^{25}$ ), a comparação entre gene e meme nos parece válida se compreendemos que essas unidades dependem do homem para se replicar, mas também são elementos que vivem para além da consciência de determinado homem, no sentido de que nós, enquanto seres biológicos, morremos, mas a vida dos signos (ou memes) se perpetua na cultura.

Reproduções de símbolos nas formas acústica ou escrita são a rigor coisas mortas (fenômeno de secundidade), mas símbolos enquanto terceiridade genuína se perpetuam como seres autorreplicantes. Uma das ações do símbolo é criar réplicas de si mesmo, suas corporificações (CP 4.447; 1903). É verdade que símbolos não podem se replicar sozinhos. Como um parasita que se reproduz apenas no organismo de outra espécie, um símbolo precisa de um utilizador para se replicar. Certamente nós, usuários do símbolo, somos seres semióticos vivos, também, mas não somos os criadores dos símbolos que usamos. Não detemos os direitos autorais de nossas próprias palavras, uma vez que não as inventamos. No mesmo sentido podemos dizer, em complemento a Peirce e Serres, que nós somos os parasitas dos símbolos que utilizamos e dos quais nos nutrimos - bem ao contrário daqueles que sustentam o oposto, que o símbolo (respectivamente à linguagem) é o parasita (por ex., Salverda 1998; Kortlandt 2002). (NÖTH, 2012, p. 3-4)

É nesse sentido que queremos entender os memes como dotados de uma vida própria e certamente mais longa que a nossa: uma existência fundada na coletividade que permite que eles, enquanto signos em sua terceiridade, se perpetuem no tempo e no espaço, mas sem excluir em qualquer hipótese a agência humana neste processo.

Observamos também que essa aproximação que fizemos dos memes com os signos, nos permite pensar algumas propostas da memética incluindo a compreensão do sujeito, isto é, refletir semioticamente acerca da evolução dos memes. Um ponto que

\footnotetext{
${ }^{25}$ Para Peirce, um signo, ou representamen, é "aquilo que, sob certo aspecto ou modo, representa algo para alguém. Dirige-se a alguém, isto é, cria na mente dessa pessoa um signo equivalente, ou talvez um signo mais desenvolvido". Ao signo assim criado, Peirce denomina interpretante do primeiro signo. "O signo representa alguma coisa, seu objeto. Representa esse objeto não em todos os aspectos, mas com referência a um tipo de ideia" que o filósofo, por vezes, denominou "fundamento do representamen" (C.P 2.228).
} 
podemos pensar, por exemplo, é a ideia de fidelidade da cópia. Questionamos a noção da fidelidade na replicação por uma dificuldade em definir os limites da variação entre um meme e sua réplica, para que essa réplica ainda seja considerada cópia do mesmo meme. Ilustramos e refletimos tal contestação a partir do exemplo das paródias da Canção do Exílio, poesia de Gonçalves Dias, que mencionamos anteriormente. Dawkins, ao discutir a também a questão da fidelidade da cópia, dá como exemplo a própria teoria do gene egoísta como uma possível variação da teoria darwinista:

[...] quando dizemos que todos os biólogos hoje em dia acreditam na teoria de Darwin, não queremos dizer que cada biólogo tem, gravada no seu cérebro, uma cópia idêntica das palavras exatas de Charles Darwin. Cada indivíduo tem a sua própria maneira de interpretar tais ideias, e provavelmente as aprendeu não a partir dos textos de Darwin, mas de autores mais recentes. Muito do que Darwin afirmou pode ser considerado, em seus detalhes, incorreto. Se Darwin lesse este livro, dificilmente reconheceria nele a sua teoria original, embora eu goste de pensar que o modo como a apresento o agradaria. No entanto, apesar de tudo isso, há qualquer coisa do Darwinismo que está presente na cabeça de cada indivíduo que compreende a sua teoria. (DAWKINS, 2007, p. 335)

Buscando uma reflexão semiótica acerca da variação, entendendo o meme como um signo, margens de mudança como essas podem ser apreendidas como parte do crescimento desse signo. Podemos dizer, grosso modo, que a teoria de Darwin, enquanto um signo, apresenta uma potencialidade para significar (interpretante imediato), podendo ser entendida de maneiras diversas, cada compreensão dessa teoria seria uma atualização do signo ideias de Darwin (interpretantes dinâmicos), isto é, efeitos atuais do signo, resultado de sua ação. Tomando assim o meme em um contexto de compreensão e não de simplesmente transmissão, ou seja, tomando-o como um signo, podemos entender as réplicas como parte do meme, pois ainda que não sejam cópias fiéis e justamente por não serem cópias, integram sua semiose: "para Peirce o signo nunca é algo repetitivo", no sentido de que "cada vez que se volta a usá-lo é um novo ato de semiose, que acarreta renovação e, portanto, determina que seu interpretante não possa estar estabilizado: trata-se do princípio peirciano da semiose ilimitada" (PONZIO, 2008, p. 165).

Esse entendimento do meme como signo nos permite mais uma aproximação com o que foi sugerido anteriormente acerca dos suportes para essas unidades replicadoras, o que nos reenvia à questão mente e cérebro, uma vez que outro problema em tratar o pensamento como parte do cérebro seria o não reconhecimento da externalidade desse pensamento. Contudo, de certa maneira, os memeticistas parecem reconhecer essa externalidade da mente quando dizem que os memes também se alojam 
em suportes físicos. Como exposto no trecho que tratamos da disputa entre memes, "nossos cérebros" não seriam os únicos veículos para eles, podendo essas unidades replicadoras, de acordo com alguns autores (MATOS, 2008; BLACKMORE, 1999; DAWKINS, 2007), também serem transportadas em suportes como jornais, computadores, livros, placas, roupas, entre outros. Desse modo, quando trazemos a abordagem dos memes como um fenômeno de consciência, não excluímos a noção de materialidade dos signos: há continuidade entre material e mental, os fenômenos da mente (os signos) não estão localizados somente no cérebro, estão em um trânsito de pensamentos (como veremos nos capítulos a seguir).

A partir das provocações que tiramos das críticas à memética e das aproximações que fizemos das ideias de meme e signo, acreditamos que o direcionamento que pretendemos dar à pesquisa se identifica mais com uma ideia de cultura que inclua "outros pontos de vista" que não só o dos memes. Com essa afirmação, nossa intenção não é julgar como errônea a abordagem de Dawkins, mas no que concerne o fenômeno que pretendemos analisar e a hipótese de entendê-lo como uma linguagem de um meio de comunicação, a memética torna-se insuficiente para responder algumas questões que nos colocamos ao longo da investigação do fenômeno. Nesse sentido, além de a proposta de Dawkins e seus colegas estar focada em instâncias como sobrevivência, perenidade, hereditariedade e evolução, essa abordagem propõe um entendimento geral da cultura e, no caso dos memes da internet, temos um fenômeno com certas especificidades que, para a nossa análise, são relevantes - como o fato de ele estar contextualizado em um cenário de comunicação social. Nesse sentido, pensar os memes no ambiente da internet nos instiga uma reflexão sobre a influência e o impacto do meio no curso da cultura, o que implica a interação social mediada, como se configuram os memes em seu devir, que aspectos conformam suas possíveis significações, entre outros fatores.

No entanto, devemos reconhecer que a escolha do termo meme para denominar o fenômeno que ocorre na internet não é totalmente aleatória. Como foi exposto, a proposta do etólogo destinava-se a entender determinada cultura em uma perspectiva análoga à genética e, portanto, mais preocupada com a "sobrevivência" e a perpetuação das informações e comportamentos. O empréstimo do termo para definir o fenômeno da internet, contudo, nos parece ter partido de um ponto específico tratado na teoria de Dawkins, que seria a replicação, e com ela, a repetição de determinada informação. Assim, o que se entende por "meme" no discurso da cultura da internet pode ser 
definido brevemente como um fenômeno caracterizado pela rápida difusão de ideias, brincadeiras, jogos, piadas, comportamentos e conceitos entre os usuários da rede, i.e., a circulação viral de informações que se repetem de determinada maneira (MORAIN, 2009, p. 2; FONTANELLA, 2009b, p. 8; BAUCKHAGE, 2011, p. 42). Desse modo, o que os memes de Dawkins e os memes da internet têm em comum é o fato de existirem pela gama de suas réplicas, existem enquanto tais graças à serialidade de suas "cópias".

O entendimento da multiplicação dos memes como um processo viral provém de mais uma metáfora com a biologia e é um termo recorrente na cibercultura, referindo-se justamente ao rápido espalhamento de determinado artefato cultural publicado online. Desse modo, o termo "viral" é uma analogia entre a transmissão de um vírus de uma pessoa a outra e a transmissão de uma mensagem de um usuário da internet a outro, e o fato de a mensagem poder alcançar grandes proporções na rede pode ser comparado a uma epidemia viral (BARRICHELLO e OLIVEIRA, 2010, p. 35). A partir dessa definição, nos permitimos uma digressão para traçar uma diferença essencial entre o vídeo viral, muitas vezes chamado apenas de "viral", e o meme, que pudemos notar, pelas leituras para a pesquisa e pela vivência no ambiente virtual, que são conceitos por vezes confundidos. A distinção entre os dois consiste basicamente no aspecto de mutabilidade que as unidades meméticas da internet possuem. Elas "parecem se espalhar e sofrer mutações através de redes difusas, de modos que os produtores originais não podem determinar ou controlar” (BURGESS, 2008, p. 101, tradução nossa $\left.{ }^{26}\right)$. Podemos, assim, conceituar os memes como vídeos, frases, hashtags, fotolegendas, tirinhas, montagens, entre outras manifestações, que sofrem uma intervenção direta de quem os reproduz, diferenciando-os dos virais que são vídeos que foram largamente compartilhados, sem necessariamente ter passado por um processo de recriação.

Notamos, desse forma, que o conceito inicial de Richard Dawkins foi apropriado para definir um fenômeno cibercultural com certas particularidades que o diferenciam da noção primeira de meme. O próprio etólogo reconhece mais tarde essa distinção:

A própria ideia de meme sofreu mutações e evoluiu em uma nova direção. E
o meme da internet é um sequestro da ideia original. Em vez de modificar-se
ao acaso, em vez de se propagar na forma de uma seleção darwiniana, os
memes da internet são deliberadamente alterados pela criatividade humana.
Na versão sequestrada, mutações são esboçadas, não aleatoriamente, com o

26 “'[...] they appear to spread and mutate via distributed networks in ways that the original producers cannot determine and control." 
total conhecimento da pessoa que está realizando a mutação. (DAWKINS, 2013, tradução nossa ${ }^{27}$ )

Dessa maneira, ao pesquisar os memes da internet, de certa maneira, damos continuidade a um estudo etimológico do termo cunhado por Dawkins. Afinal, o emprego do vocábulo para definir uma gama de manifestações imagéticas, audiovisuais e verbais na internet culminou no acréscimo de novos contornos ao vocábulo "meme", um pouco diferentes daqueles inicialmente apresentados na obra Gene Egoísta. Expandimos, assim, a proposta inicial de Dawkins, mostrando que o termo "meme" incorporou e passou a representar também o sentido de "meme da internet", que, apesar de ser um fenômeno cultural que poderíamos entender dentro da lógica de Dawkins, faz parte de um contexto específico, o da internet como meio de comunicação. Vejamos a seguir quais são as implicações de entender os memes no cenário da internet e como podemos compreendê-los como linguagem desse meio.

\footnotetext{
27 "The very ideia of meme has itself mutated and envolved in a new direction. And internet meme is a hijacking of the original idea. Instead of mutating by random chance, before spreading by a form of Darwinian selection, internet memes are altered deliberately by human creativity. In a hijack version, mutations are designed not ramdom with the full knowledge of the person doing the mutating". Informação oral: <http://www.youtube.com/watch?v=GFn-ixX9edg> acesso em 17/10/2014.
} 


\section{CAPÍTULO 2. MEIO E CULTURA}

“O pensamento está dentro de nós, mas nós estamos
dentro do pensamento. [...]É tanto algo engendrado
pelo cérebro humano, quanto algo ao nosso redor."
Iuri Lotman

Herdado das reflexões de Dawkins, como vimos, o termo meme passou a ser entendido vinculado ao contexto da comunicação mediada pela internet. Desse modo, referir-se a um meme nas últimas décadas, no senso comum, passou a ser, basicamente, referir-se a um meme da internet. E foi justamente essa atribuição do termo a algo que estava acontecendo corriqueiramente nas nossas práticas comunicativas o que suscitou a nossa surpresa: havia algo se repetindo com certa regularidade nas interações em rede, de modo que essas ocorrências frequentes já estavam inclusive sendo nomeadas com o mesmo vocábulo por seus praticantes na web.

Observamos, assim, que certo padrão de expressão, isto é, uma forma particular de dispor, circular e ressignificar as informações estava emergindo na internet e exigindo uma espécie de "letramento" e partilha de conhecimentos para a sua prática e para a compreensão das mensagens veiculadas. A percepção do fenômeno dessa maneira nos levou à hipótese de que os tais memes poderiam configurar certo tipo de linguagem, uma vez que operavam a partir de algumas regras que não foram preestabelecidas, porém eram conhecidas e compartilhadas, padronizando os modos de comunicar ao ponto de destacar-se de outras formas de expressão, ao mesmo tempo configurando uma forma de entendimento da realidade, uma maneira particular de ver o mundo.

A presença do meio de comunicação na definição do meme pelos usuários, isto é, tratar as diversas manifestações que surgiam como memes da internet, também nos propôs uma reflexão acerca do impacto do próprio meio no fenômeno que nele surgia, nos conduzindo a um questionamento complementar à hipótese de o meme ser uma linguagem: poderíamos pensar em uma linguagem da internet? Questão que emerge também da observação da ideia de linguagem associada a outros meios e técnicas, como "linguagem televisiva", "linguagem cinematográfica", "linguagem fotográfica". 
Nesse sentido, a partir dessas ponderações, esse capítulo possui o objetivo de lançar luz à relação entre meio de comunicação, linguagem e cultura. Acreditamos que para entender esse vínculo torna-se necessário aclarar o que estamos tomando aqui como meio de comunicação. Nesse sentido, visamos compreendê-lo para além de seu aspecto físico (mecânico, eletrônico) no entendimento de que para ser meio de comunicação uma tecnologia não pode ser vista apenas como um suporte, mas sim como um ambiente que promove interação de consciências, podendo desse modo operar como um dispositivo que articula cultura. Essa compreensão de que o meio cria um ambiente cultural, uma semiosfera, um espaço de transformação, compreensão e interação textual, nos permitirá ainda revisitar Dawkins e a sua proposta de sopa primordial, como também veremos neste capítulo.

\subsection{Meio, impactos e extensões}

Antes de estabelecer o que configuraria a linguagem de um meio, e por sua vez o meme como uma linguagem da internet, parece-nos fundamental explorar, ainda que de modo breve, a própria compreensão que podemos fazer do que seja um meio de comunicação. Para tanto, procuramos nas tradições teóricas da comunicação aquela que nos desse uma perspectiva que de fato depositasse um olhar mais cuidadoso e dedicado às tecnologias da comunicação. Encontramos, assim, na teoria do meio um ponto de articulação com o nosso objeto na compreensão dos memes como linguagem da internet.

A escolha dessa tradição teórica se justifica, assim, por ela ter de fato o meio de comunicação como objeto de estudo. Como nos mostra Meyrowitz em seu estudo dos meios eletrônicos na obra No Sense of Place, e Martino em uma breve análise que faz das tradições de pesquisa da comunicação de massa, muitos dos estudos sobre os meios acabaram por ignorá-los, se não deixa-los à margem, uma vez que na realidade seu foco encontra-se na mensagem, nos polos de emissão e recepção e nas condições de transmissão dessas mensagens ou em críticas ao sistema político e econômico a partir de um entendimento do meio como instituição (MARTINO, 2000; MEYROWITZ, 1985).

O que esses autores buscam mostrar é que, nas palavras de Meyrowitz, 
filmes ou dos romances foram estudados. O meio em si é visto como um sistema de entrega neutro. (MEYROWITZ, 1985, p. 15, tradução nossa ${ }^{28}$ )

Assim, pela perspectiva da teoria do meio, podemos vislumbrar os meios de comunicação não como um suporte passivo, mas como uma tecnologia que produz impactos nos nossos modos de comunicar, pensar e agir, não se tratando de um espaço inerte pelo qual as mensagens passam.

Destacamos na sustentação e desenvolvimento dessa ideia o pensamento do filósofo canadense Marshall McLuhan, que, estendendo aspectos das reflexões de Harold Innis, se propôs a investigar não só a repercussão e os impactos dos meios nos nossos processos comunicativos diários, mas também como a inserção de um novo meio na matriz dos meios de comunicação traz mudanças de ordem social, cultural e cognitiva:

\begin{abstract}
O que não veem nem os entusiastas nem os céticos é o que McLuhan viu: que, em longo prazo, o conteúdo de um meio importa menos que o meio em si na hora de influenciar em como pensamos e agimos. Como janela para o mundo, e para nós mesmos, um meio popular molda o que e como vemos - e com o tempo, se o usamos suficientemente, nos muda, como indivíduos e como sociedade. (CARR, 2010, p. 3, tradução nossa ${ }^{29}$ )
\end{abstract}

O que McLuhan perseguiu em seus escritos, assim, foi entender como e por que os efeitos dos meios modificam o homem e a sociedade (BARBOSA, 2010, p. 32). Tratando mais especificamente do homem, McLuhan buscou desenvolver a ideia de que os meios geram impactos que incidem diretamente em nós (em nosso corpo) e, por assim dizer, na nossa maneira de apreender o mundo. Essa noção estaria sustentada pela ideia de que os meios (tecnologias) funcionam como extensões do homem - como um martelo que pode ser entendido como uma extensão da mão, um automóvel de nossas pernas ou ainda a escrita da nossa memória. Assim, McLuhan analisa cada meio como uma extensão de um ou mais sentidos, membros ou processos humanos, sugerindo que o uso das diferentes tecnologias afeta tanto a estrutura da cultura, quanto a organização dos sentidos humanos (MEYROWITZ, 1994, p. 52), uma vez que a introdução de um novo meio na cultura muda o "equilíbrio sensorial" dos indivíduos e altera suas consciências (MEYROWITZ, 1986, p. 3).

\footnotetext{
28 "Indeed, most of the studies of the impact of media ignore the study of the media themselves. The content and the control of television are studied the same way the content and the control of newspapers, comics, movies, or novels have been studied. The medium itself is viewed as a neutral delivery system."

29 "What both enthusiast and skeptic miss is what McLuhan saw: that in the long run a medium's content matters less than the medium itself in influencing how we think and act. As our window onto the world, and onto ourselves, a popular medium molds what we see and how we see it - and eventually, if we use it enough, it changes who we are, as individuals and as society."
} 
Assim, quando analisa os impactos do alfabeto fonético, por exemplo, em $A$ Galáxia de Gutenberg, a partir dos estudos de J. C. Carothers sobre a cultura nãoalfabetizada de algumas comunidades rurais africanas, McLuhan procura mostrar que pela escrita, e em seguida por meio da tecnologia de Gutenberg, o sentido da visão foi estendido, separando-se da audição, sentido predominante nessas comunidades, cuja comunicação se constituía essencialmente na oralidade. $\mathrm{O}$ autor canadense propõe, assim, a ideia de um "homem destribalizado", um indivíduo "para quem os valores visuais têm prioridade na organização do pensamento e da ação" (1966, 52). Acrescenta ainda que o prolongamento da visão, por meio dos livros e do advento da tipografia, teria condicionado o homem à racionalidade, ao individualismo e à linearidade (McLUHAN apud BARBOSA, 2010, p. 33), desse modo, tecnologias como o alfabeto e a tipografia teriam alterado nossos sentidos e por consequência nossa maneira de ver o mundo.

Não caberia empreender para fins dessa investigação um estudo minucioso dos diversos aspectos dos meios abordados no pensamento de McLuhan, porém essa breve retomada nos serve para observar a provocação que esse autor empreendia com sua proposta teórica, a de pensar as tecnologias como agentes transformadores, tanto de nós individualmente, como do corpo social: "Qualquer extensão - seja da pele, da mão ou do pé - afeta todo o complexo psíquico e social” (McLUHAN, 1964, p. 17). A partir do pensamento do filósofo canadense, apresentado aqui em linhas gerais, podemos pensar, assim, que os meios podem originar novos modos de ver, pensar e dar sentido ao mundo e, por assim dizer, originar linguagem. A nosso ver, entretanto, o entendimento da internet como meio de comunicação não se ajusta a uma extensão de um membro do corpo humano ou mesmo no prolongamento de algum sentido humano. Para compreendê-la enquanto uma esfera cultural que proporciona formas de entender o mundo como a linguagem do meme, esse meio opera como uma outra extensão do homem, que não a de membros ou sentidos, mas sim um prolongamento de outra porção inerente ao homem, também sugerido por McLuhan em Os meios de comunicação como extensões do homem:

Depois de três mil anos de explosão, graças a tecnologias fragmentárias e mecânicas, o mundo ocidental está implodindo. Durante as idades mecânicas projetamos nossos corpos no espaço. Hoje, depois de mais de um século de tecnologia elétrica, projetamos nosso próprio sistema nervoso central num abraço global, abolindo tempo e espaço (pelo menos naquilo que concerne ao nosso planeta). Estamos nos aproximando rapidamente da fase final das extensões do homem: a simulação tecnológica da consciência pela qual o processo criativo do conhecimento se estenderá coletiva e corporativamente a 
toda a sociedade humana, tal como já se fez nossos sentidos e nervos através dos diversos meios e veículos. (McLUHAN, 1964, p. 17, grifo nosso)

Desse modo, é entendendo a internet como extensão da consciência que podemos pensá-la como um meio de comunicação e, enquanto tal, também um ambiente cultural, uma esfera na qual linguagens se organizam.

\subsection{A internet como extensão da consciência}

Ao nos referimos à internet como um meio de comunicação é preciso aclarar o uso que fazemos desse termo, "internet". A rigor, a palavra nomeia uma tecnologia que consiste em uma rede de computadores, isto é, de dispositivos interconectados, portanto, simplesmente um suporte. No entanto, quando falamos da internet enquanto um meio de comunicação, nos referimos ao que essa conexão proporciona ao permitir interações comunicacionais.

Nesse sentido, a compreensão de uma tecnologia como meio de comunicação depende antes de tudo do que se toma como meio propriamente dito. Como nos sugere Martino (2000, p. 107), podemos pensar em três acepções de meio. A primeira, como esboçado acima, é a que diz respeito ao seu plano tecnicista, na qual os meios aparecem como sinônimo de suporte físico. A segunda maneira de defini-los é tomando-os por seu âmbito institucional, nesse sentido, a acepção de meio nesse plano seria a de identificar como meio de comunicação a empresa que controla a emissão, no caso da televisão ou do rádio, por exemplo; ou os grandes grupos que detêm um sistema de busca ou que controlam uma rede social, no caso da internet. Ou seja, trata-se de um entendimento de meio enquanto veículo, envolvendo divisão de trabalho, gestão e elaboração da informação, em uma perspectiva profissional. E, por fim, a terceira acepção, a que nos interessa aqui, é a definição do meio como um eletrodoméstico, ou seja, tomado não apenas por sua dimensão técnica, mas entendido como a interação entre um dispositivo técnico e seu utilizador.

Assim, quando empregamos nesta investigação o termo "internet", não estamos nos referindo exclusivamente ao plano técnico. Esse plano por si só não constitui um meio de comunicação: se pensarmos em uma TV ligada em um ambiente vazio, não teríamos nessa situação um meio de comunicação, "um jornal, rádio ou TV executam seu papel na presença do leitor i.e., qualquer um desses dispositivos sozinhos em uma sala não seria mais que do que isso, componentes físicos e mecânicos" (RUSSI, 2013, p. 
49). Desse modo, posto que o meio do qual tratamos aqui não é unicamente material, o que entendemos por meio de comunicação se dá, na realidade, pela viabilização da técnica em estabelecer relações com outros indivíduos: é a ação e a intenção de consciências que fundamentam o suporte como meio de comunicação (idem). Assim sendo, a comunicação é a interação (ação) dos sujeitos com o dispositivo técnico e pelo dispositivo técnico - e é essa ação que concede a determinado suporte a função de meio de comunicação.

O meio consiste, assim, em uma manifestação técnica e, como tal, se apresenta como uma extensão do homem. A concepção de técnica dada por Martino é uma adaptação ao caso dos meios de comunicação da abordagem de Leroi-Gourhan. Segundo o autor francês, a técnica não está no objeto e tampouco é produto direto do corpo do indivíduo: ele vê como princípio da evolução técnica a capacidade de exteriorização fundamentada por uma capacidade de simbolização. A atividade técnica se realiza, assim, a partir de um raciocínio (racionalidade) que permite ao indivíduo encontrar equivalências funcionais (em termos simbólicos) - por exemplo, isolar uma função da mão e estendê-la no martelo. Os dois objetos não têm nada em comum, mas têm funções equivalentes. Conclui Martino: "Pode-se dizer que a racionalidade técnica é um equacionamento simbólico, um modo de perceber o 'mundo', que permite substituições funcionais" (2000, p. 110).

Como vimos, acreditamos que para o entendimento dos memes como linguagem, como uma forma de compreensão de mundo, a ideia de uma extensão dos sentidos não elucidaria a questão que estamos propondo. Assim, partindo do que argumenta Martino e outros pensadores da técnica, admitindo, portanto, a ideia de que todo dispositivo é uma extensão de um órgão, de uma função ou ainda de uma faculdade do corpo humano, poderíamos pensar que os meios de comunicação, como o próprio nome sugere, prolongam nossa faculdade de comunicação, que por sua vez é uma propriedade da consciência:

[...] mas a que corresponde a comunicação em relação ao corpo humano? A resposta mais uma vez não admite nenhum equívoco, quer dizer, trata-se da consciência já que a comunicação é uma relação de consciências.

Os meios de comunicação são, então, objetos técnicos que guardam uma relação bastante especial com a consciência na medida em que se manifestam como uma extensão da consciência ou, como nós preferimos dizer, como simulação da consciência. (MARTINO, 2000, p. 109 e 110)

A ideia de "simulação" proposta por Martino não nos parece estar direcionada a um sentido de um falseamento, fingimento ou como algo ficcional, como o termo pode 
sugerir. Martino usa esse termo, pois argumenta que, diferentemente da relação de extensão da mão e do martelo, na qual tínhamos uma analogia simbólica e relativamente arbitrária, a "analogia entre a informação virtual contida num suporte material [meio] e o ato de sua decodificação [consciência] se funda sobre uma continuidade ontológica" (ibidem, p. 111), isto é, ambas possuem a natureza de atos de consciência, ambas se manifestam por signos. Assim, codificar e decodificar uma mensagem podem ser tomados como ações da consciência, da mente, assim como uma mensagem veiculada em um suporte - nesse segundo caso, tratando-se de uma manifestação da consciência (idem).

Essa "continuidade ontológica" explica-se no entendimento de que a mente é um fenômeno externo, como propõe Peirce. Para ele, o homem é um signo em constante semiose, crescimento. A mente não se localizaria, portanto, na cabeça, estando na realidade em um trânsito de pensamentos (semiose). Para ele, "a mente é um signo desenvolvendo-se de acordo com as leis da inferência”, não tendo assim um lugar, sendo na realidade o resultado do processo inferencial de conhecer (PEIRCE apud SILVA, 2012, p.147):

O homem-signo adquire informação, e vem a significar mais do que anteriormente. As palavras também. "Eletricidade" não significa mais hoje do que nos dias de Franklin? O homem faz a palavra, e a palavra não significa nada mais do que o homem a faça significar, e isto apenas a alguns homens. Mas já que o homem pode pensar apenas por meio de palavras ou outros símbolos externos, elas podem virar-se e dizer: "Você não é nada mais do que aquilo que te ensinamos, e apenas na medida em que você se dirija a uma palavra como interpretante do seu pensamento". De fato, portanto, homens e palavras reciprocamente educam-se uns aos outros; cada crescimento de informação em um homem envolve e é envolvida por um acréscimo correspondente de informação em uma palavra. (CP 5.313 apud SILVA, 2012, p. 148)

Essa noção se insere na doutrina do contínuo (sinequismo), que nos permite compreender a semiose de maneira mais ampla, doutrina na qual a mente pode ser pensada "na processualidade da ação do signo" (SILVA, 2012, p. 149, grifo do autor). Nesse sentido, entendendo que a mente tem um aspecto interno, mas é também um fenômeno externo por estar nessa processualidade, podemos afirmar que “ [...] a mente de um indivíduo não está só no crânio, como também nos textos que escreve e lê, nas pessoas com quem interage, nas atividades que desempenha etc." (idem).

Podemos pensar, assim, que há uma continuidade que permite que o pensamento esteja tanto na mente quanto em suportes físicos. Essa noção sustenta o entendimento de Martino de que a analogia funcional entre consciência e meio não é 
simplesmente arbitrária, pois o meio de comunicação e a consciência estabelecem uma relação de identidade, isto é, ambos possuem natureza sígnica - o que enseja os meios a simularem (nos termos de Martino) a própria faculdade que temos de representar o mundo (MARTINO, 2000, p. 111).

\subsection{O espaço semiótico da cultura e da linguagem}

Partindo, assim, do que argumenta Martino, na afirmação de que os meios de comunicação estão visceralmente ligados à consciência e reproduzem tecnicamente sua função, nos permitimos vislumbrar a ideia de que o meio, ao reproduzir funções, opera como uma consciência. Entendido dessa forma, poderíamos pensar os meios de comunicação também como uma cultura, como propõe Iuri Lotman:

[...] Lotman formula a noção de cultura como dispositivo pensante dotado, portanto de inteligência e de memória, vale dizer, de ordenamento e de capacidade gerativa. Graças a esse dispositivo a cultura é espaço de mente. Nele mecanismos de transformação e transmutação de energias geram informações novas identificadas como ação inteligente. (MACHADO, 2007, p. 58 e 59)

Assim, tomando o meio como uma extensão da consciência (uma simulação da consciência), preenchido por um contínuo de signos, podemos entendê-lo como um espaço da mente e, por conseguinte, como uma cultura, uma vez que esta opera como um dispositivo pensante, como se fosse uma consciência, estando dotada de memória, ação inteligente e da capacidade de produzir hábitos. De uma perspectiva semiótica, Lotman afirma que a cultura consiste em "inteligência coletiva" e "memória coletiva", ou seja, um "mecanismo de conservação, transmissão e recepção de certos textos" (ARÁN, 2001, p. 53, tradução nossa ${ }^{30}$ ),

[...] o conjunto de toda a informação não hereditária e dos meios para a sua conservação e transmissão. Não é um mero depósito, senão um mecanismo organizado e complexo, que recebe, traduz, compacta e interpreta a materialidade produtiva que adota a função de signos. (ARÁN, 2001, p. 49, tradução nossa ${ }^{31}$ )

O que sustenta essa noção é a ideia de semiosfera de Lotman, quem integra um grupo de pensadores do século passado que se propuseram a investigar a maneira como pensamos o mundo ou como interagem os elementos que nele se desenvolvem (MACHADO, 2007, p. 57). Entre esses pensadores também se encontra Claude

\footnotetext{
30 “[...] mecanismo de conservación, transmisión y recepción de ciertos textos."

31 "[...] el conjunto de toda la información no hereditaria y de los medios para su conservación y transmisión. No es un mero depósito, sino un mecanismo, organizado y complejo, que recibe, traduce, compacta e interpreta la materialidad productiva que adopta la función de signos."
} 
Shannon com sua teoria matemática da informação, que serviu como um contraponto para Lotman pensar a semiosfera. O que propunham os "engenheiros da comunicação" era entender a comunicação como uma simples transmissão de informação, na qual haveria uma coincidência de códigos ${ }^{32}$ entre emissor e destinatário (LOZANO, 1995), um sistema que funciona de modo isolado. Contrapondo a esse sistema informacional, bipolar e fechado, Lotman vai compreender a cultura como um dispositivo pensante, uma vez que a comunicação não é, para ele, transporte ou transmissão, mas sim, “a transmutação de energias criadoras" (MACHADO, 2007, p. 61), que, nos termos do semioticista russo, geram "nova informação". Tratar, portanto, o meio de comunicação (uma semiosfera por assim dizer) como um sistema de ações inteligentes (e aqui acreditamos que cabe a comparação com a proposta de extensão/simulação da consciência de Martino) é entender que a comunicação se dá em um espaço que se configura como um circuito dialógico, isto é, um espaço de "relações e conexões [diálogos] entre diferentes códigos culturais" (ibidem, p. 58). Por isso entender a cultura como dotada de ação inteligente, porque ela funciona como um organismo dinamizador - e não como um sistema operador - que "deforma" o texto, trabalhando sua potencialidade semiótica, e não simplesmente o transmite no processo de comunicação.

Desse modo, a cultura se configura como o ambiente da ação inteligente e produtiva, no qual a geração de sentido se torna possível. Compreendemo-la aqui como uma semiosfera: um conceito que se tornou "um modo de pensar os modelos de cultura como espaço semiótico de suas práticas" (MACHADO, 2013, p. 62).

Lotman define esse espaço da seguinte maneira:

Como agora podemos supor, não existem por si, de forma isolada, sistemas precisos e funcionalmente unívocos que funcionam realmente. Sua separação está condicionada unicamente por uma necessidade heurística. Tomados separadamente, nenhum deles têm, na realidade, capacidade de trabalhar. Só funcionam estando submergidos em um continuum semiótico, completamente ocupado por formações semióticas de diversos tipos que se encontram em diversos níveis de organização. A esse continuum, por analogia ao conceito de biosfera introduzido por V.I Vernadski, o chamamos de semiosfera. (LOTMAN, 1996, p. 22, tradução nossa ${ }^{33}$ )

\footnotetext{
${ }^{32}$ Para Lotman, código não é apenas um sistema para codificar e decodificar mensagens, mas consiste na "totalidade da experiência verbal e da memória dos indivíduos" (LOTMAN, 1990 apud SANTAELLA; NÖTH, 2004, p. 139). Para ele, o código no sentido dos engenheiros da informação seria um sistema sem memória, destinador e destinatário estariam dotados de códigos iguais e, portanto, a compreensão entre eles seria perfeita (ibidem, p. 138), sem margem para outros entendimentos.

33 "Como ahora podemos suponer, no existen por sí en forma aislada sistemas precisos y funcionalmente unívocos que funcionan realmente. La separación de éstos está condicionada únicamente por una necesidad heurística. Tomando por separado, ninguno de ellos tiene en realidad capacidad de trabajar. Sólo funcionan estando submergidos en un continuum semiótico, completamente ocupado por formaciones semióticas de
} 
Desse modo, Lotman, assim como Dawkins, parte de uma analogia entre cultura e biologia. Diferentemente do etólogo que orientou seus estudos à elucidação da evolução cultural como um processo de transmissão "de cérebro em cérebro", o filósofo russo, partindo de uma metáfora da biosfera, propõe o entendimento do funcionamento da cultura como um organismo vivo ${ }^{34}$, no qual todos seus elementos estão em constante interação e transformação. A cultura, a semiosfera por assim dizer, é "um universo aberto e extremamente favorável à criação dos mais variados e inusitados sistemas de signos. Todos postos [...] em intensa correlação" (RAMOS et al., 2007, p. 30).

Lotman sugere um cenário imagético por meio do qual poderíamos compreender melhor o que ele concebe por semiosfera. Ele nos convida a imaginar a sala de um museu, onde encontraríamos expostos em vitrines diversos objetos de diferentes séculos, textos inscritos em línguas que conhecemos e que desconhecemos, acompanhados de instruções para sua decifração, além de textos explicativos redigidos por pesquisadores. Nesse museu, também encontramos rotas para excursões em seu interior, além de regras de conduta e comportamento para os visitantes. E criado esse cenário ilustrativo, Lotman finaliza, "se colocarmos ali também os próprios visitantes com seus mundos semióticos, obteremos algo que recordará um quadro da semiosfera" (LOTMAN, 1996, p. 30, tradução nossa ${ }^{35}$ ). A semiosfera seria, portanto, esse espaço sistêmico de elementos semioticamente ecléticos do qual nós também fazemos parte:

\begin{abstract}
A semiosfera pode ser compreendida como uma esfera sígnica que não se restringe a soma de códigos, linguagens e textos que por ela transitam (Lotman, 1990, 123). Ela pode ser vista como um ambiente no qual diversas formações semióticas se encontram imersas em diálogo constante, um espaço-tempo, cuja existência antecede tais formações e viabiliza o seu funcionamento, enquanto torna possível seu próprio ciclo vital. (RAMOS et al., 2007, p.34)
\end{abstract}

Ao descrever a semiosfera, Lotman afirma que ela é uma condição de existência da linguagem, "sem semiosfera a linguagem não funciona, como tampouco existe" (LOTMAN, 1996, p. 35). Ele concebe a semiosfera e também os diversos sistemas culturais que dela fazem parte como algo vivo, dinâmico, em ação, anterior à

diversos tipos que se allan en diversos niveles de organización. A ese continuum, por analogía con el concepto de biosfera introducido por V.I Vernadski, lo llamamos semiosfera."

${ }^{34}$ Veremos a seguir que a partir de Dawkins e Lotman podemos fazer uma comparação entre o caldo cultural e a semiosfera. No entanto, Dawkins entende a cultura como um sistema conservador e não como algo que está em constante transformação.

35 "Si colocamos allí, además, a los propios visitantes con su mundo semiótico, obtendremos algo que recordará un cuadro de la semiosfera.” 
comunicação, à linguagem e à semiose (RAMOS et al., 2007, p. 35). Assim, a internet, não apenas enquanto suporte, mas como uma extensão da consciência, se configura como um ambiente semiótico, que torna possível a existência do meme como linguagem. Enquanto linguagem, o meme também origina o seu próprio espaço semiótico e suas fronteiras:

Por um lado, as linguagens e códigos da cultura são "uma constelação de
espaços semióticos e suas fronteiras", por outro, a semiosfera é o espaço no
qual essas linguagens estão "imersas" e "ela pode funcionar apenas graças à
interação com esse espaço". (LOTMAN apud NÖTH, 2007, p. 91)

Assim, podemos entender o meme como uma cultura, com um espaço semiótico próprio (também uma semiosfera ${ }^{36}$, por assim dizer), possibilitado pelas interações na internet, esta entendida como extensão da consciência. No entanto, a ideia de que há um espaço semiótico que precede a linguagem poderia soar como um paradoxo, uma vez que, se a linguagem é cultura, como poderia a cultura preceder a linguagem? $\mathrm{O}$ paradoxo, no entanto, não chega a configurar uma contradição, se entendemos que a cultura cria e é criada pela cultura (NÖTH, 2007, p. 92), a cultura depende de processos como a comunicação, a semiose e a linguagem para sobreviver, também existindo apenas a partir deles (RAMOS et al., 2007, p.35), podemos vislumbrar, desse modo, a relação de cultura e linguagem como um organismo que se retroalimenta.

A linguagem, como entendida por Lotman, é qualquer sistema de comunicação que utiliza signos ${ }^{37}$ ordenados de modo particular" (SANTAELLA; NÖTH, 2004, p. 136), a partir disso, podemos pensar a linguagem como um sistema que apresenta uma regularidade que cria essa organização. Tomando a semiosfera do meme, seu sistema cultural por assim dizer, teremos um núcleo que representa o que ele possui de regular. A configuração desse núcleo como regularidade, entretanto, depende das próprias práticas do meme pela internet, suas várias ocorrências em redes sociais, fóruns entre outros. A regularidade a partir desses diversos usos é o que vai configurar certa "gramática do meme”, delineando, de maneira não rígida, que formações textuais podem ser tomadas como meme e quais não, e nesse sentido, o que está dentro da

\footnotetext{
${ }^{36}$ Para Lotman, todos os elementos que estão em uma semiosfera podem ser entendidos também como semiosferas particulares: "Posto que todos os níveis da semiosfera - desde a pessoa do homem ou o texto isolado até as unidades semióticas globais - representam semiosferas como se colocadas uma dentro da outra, cada uma delas é, por sua vez, tanto participante de um diálogo (uma parte da semiosfera) como o espaço do diálogo (o todo da semiosfera) [...]" (LOTMAN, 1996, p. 42).

${ }^{37}$ Aqui fazemos uma ressalva: Lotman não entende o signo da mesma forma que Peirce. Para o autor russo, "o conceito de signo se orienta pelo modelo do signo verbal: só é signo o que se destaca de maneira visível ou audível de um fundo não-sígnico" (SANTAELLA;NÖTH, 2004, p. 137).
} 
semiosfera do meme e o que não está, circunscrevendo, assim, suas fronteiras e prevendo também formações semióticas futuras semelhantes:

\begin{abstract}
As semiosferas criam sua própria meta-semiosfera de um modo auto-gerativo e auto-referencial. Elas atuam no seu próprio centro com o propósito de autoestabilização do sistema cultural (ibid.: 128): "Se nós temos em mente linguagem, política ou cultura, o mecanismo é o mesmo: uma parte da semiosfera (como via de regra é parte de sua estrutura nuclear) no processo de auto-descrição cria sua própria gramática [...]. Então ele esforça-se para estender estas normas para o conjunto da semiosfera". (LOTMAN apud NÖTH, 2007, p. 93)
\end{abstract}

Nesse sentido, podemos pensar linguagem-cultura como um sistema autogerativo e auto-organizador. É valido ressaltar mais uma vez que não devemos encarar o estabelecimento dessas normas como algo imutável e cristalizado. O que chamamos aqui de regra ou gramática é uma abstração descritiva do processo de surgimento de organização fluida de uma linguagem e sua cultura, no caso, o meme da internet. A dinâmica entre fluidez e regularidade é o que permite que a cultura transite entre espaços de conservação e de novidade:

[...] a cultura é um mecanismo gerativo e estruturador que baseia suas fronteiras na autoconsciência e auto-organização: ao mesmo tempo que a cultura tende à conservação de seus textos, incentiva também a criação de textos novos que finalmente se incorporam à sua memória e se subordinam a princípios contrutivos unitários. (ARÁN, 2001, p. 53, tradução nossa ${ }^{38}$ )

Desse modo, quando, pensando a partir de Lotman, delimitamos a linguagem do meme como um elemento de núcleo de semiosfera, a entendemos assim porque há um elemento no meme que o leva rumo a uma estabilidade, o que, tomando de empréstimo os termos de Omar Calabrese, seria um "centro organizador" (1999, p. 65). Esse centro é o resultado da formação de hábitos, do constante diálogo que esse núcleo estabelece com uma periferia (uma vez que há um centro, há também o seu contraponto periférico), por meio da incorporação de seus elementos por meio da ação inteligente de que nos falava Machado. Lotman propõe que a região periférica está organizada de maneira menos rígida, detendo construções maleáveis, “deslizantes”, uma área na qual "os processos dinâmicos encontram menos resistência e, por conseguinte, se desenvolvem mais rapidamente.” (LOTMAN, 1996, p. 30, tradução nossa ${ }^{39}$ ). São regiões próximas às fronteiras da semiosfera, que têm a função de separar o próprio do alheio, do que não

\footnotetext{
38 "Un concepto clave para la Semiótica de Tartu es que la cultura es un mecanismo generativo y estructurador que basa sus fronteras en la autoconciencia y la autoorganización: al mismo tiempo que la cultura tiende a la conservación de sus textos, impele también la creación de textos nuevos que finalmente se incorporan asu memoria y se subordinan a principios constructivos unitarios."

39 “[...] los procesos dinámicos encuentran menos resistencia $\mathrm{y}$, por conseguiente, se desarollan más rápidamente."
} 
faria parte da cultura dos memes, no caso, do que ainda não foi traduzido para os "moldes" da linguagem dos memes. A função da fronteira, desse maneira, é "limitar a penetração do externo no interno, a filtrá-lo e elaborá-lo adaptativamente", fazendo, assim, "a filtragem das mensagens externas e a tradução destas linguagens à linguagem própria, assim como a conversão das não-mensagens externas em mensagens" (ibidem, p. 26, tradução nossa ${ }^{40}$ ). Podemos entender essa filtragem como a forma de incorporar elementos alheios à semiosfera ao seu interior. Essa "culturalização" é a forma de a linguagem configurar a sua maneira de compreender o mundo, sendo esse mundo o alheio, o externo, a "não-cultura", que pode ser simplesmente uma outra cultura, um texto em uma outra linguagem.

\subsection{Um retorno ao meme de Richard Dawkins}

Entendida a cultura como uma semiosfera, cabe aqui relançar o nosso olhar à teoria do meme de Dawkins e seus seguidores para algumas ponderações que nos apontam que há de fato algumas divergências entre a sua perspectiva e a da semiótica de Iuri Lotman em suas concepções de cultura, mas que algumas aproximações são também possíveis. Como nos mostra Ronaldo Henn, a proposta de Dawkins teria ganhado densidade epistemológia se tivesse se articulado com a noção de semiosfera de Lotman (HENN, 2014, p. 42).

Revisitando Dawkins, relembramos que a sua compreensão da cultura se edifica na ideia de meme, que seria uma unidade análoga ao gene - no caso, uma unidade cultural construída na teoria memética a partir de diversas comparações com o comportamento da unidade genética. Como vimos, a proposta de entendimento da evolução genética deste cientista se funda no egoísmo do gene, revelando-nos que o processo evolutivo e as relações de disputa interespecíficas e altruísmo intraespecíficos não se fundamentariam na busca de um bem do indivíduo ou da espécie, mas sim, no egoísmo do gene que faria de tudo, a qualquer custo, para perpetuar única e somente a sua existência. Para estender sua "vida", assim, o gene teria criado máquinas de sobrevivência. Essa seria uma das analogias que Dawkins estabelece: o fato de que tanto

\footnotetext{
40 “ $[\ldots]$ limitar la penetración de lo externo en lo interno, a filtrarlo y eleborarlo adaptativamente [...] el filtrado de los mensajes externos y la tradución de éstos al lenguaje proprio, así como la conversión de los no-mensajes externos en mensajes $[\ldots]$ "
} 
os memes quanto os genes dependem dessas máquinas para dar continuidade ao seu processo evolutivo, isto é, para serem passados adiante no curso de suas existências.

Essas máquinas de sobrevivências seriam nós mesmos ${ }^{41} \mathrm{e}$, na explicação genética, as máquinas teriam sido originadas em uma dinâmica de transformações no caldo primordial, que biólogos e químicos acreditam ter constituído os mares da Terra entre 3 e 4 bilhões de anos atrás: um ambiente formado inicialmente por matérias químicas tais como água, dióxido de carbono, metano e amônia, que após sofrer descargas elétricas e a incidência de raios ultravioletas, teria dado origem às primeiras moléculas orgânicas. Entre elas estaria uma molécula com uma aptidão especial (DAWKINS, 2007, p. 57-59):

Em algum momento formou-se, por acidente, uma molécula particularmente notável. Vamos chamá-la de o Replicador. Não é preciso que ela tenha sido a maior ou a mais complexa molécula existente, porém ela tinha uma propriedade extraordinária: a capacidade de criar cópias de si mesma. Ela pode parecer um tipo de acidente cuja ocorrência é muito pouco provável. E foi, de fato. (DAWKINS, 2007, p. 59)

Entretanto, o processo de produzir cópias de si mesma dessa molécula inicial não era perfeito, ocorrendo em sua reprodução alguns erros. Essas cópias errôneas replicavam-se e propagavam-se e, com o passar do tempo, o caldo primitivo foi preenchido não por uma população de réplicas idênticas, mas por uma diversidade de moléculas replicadoras, havendo luta pela sobrevivência entre elas. Essa competição, em um processo paulatino e cumulativo de "melhoramento", originou replicadoras que conseguiam garantir maior estabilidade ao passo que diminuíam a estabilidade de suas rivais, tornando-se mais elaboradas e mais eficientes (ibidem, p. 64-65). Nesse processo teriam surgido as primeiras máquinas de sobrevivência, a partir de moléculas que desenvolveram a capacidade de construir abrigos: "Talvez tenha sido assim que as primeiras células vivas apareceram. Os replicadores começaram não apenas a existir, mas também a construir invólucros para si mesmos, veículos capazes de preservar sua existência." (ibidem, p. 66). Como apresentado no capítulo anterior, nós, as máquinas, somos mortais, diferentes dos genes (e dos memes) que, por meio de suas cópias, conseguem se perpetuar potencialmente para a eternidade.

Reconhecendo que Dawkins ampara seu entendimento em comparações entre meme e gene, é válido vislumbrar uma aproximação da semiosfera com a noção de "caldo cultural" (analogia à sopa primordial dos genes): assim como na semiosfera estão

\footnotetext{
${ }^{41}$ No caso dos memes, podemos entender o suporte em que eles se propagam também como máquinas de sobrevivência, uma vez que a informação memética, na perspectiva da teoria de Dawkins e seus seguidores, também se propaga por meios materiais, além do cérebro humano, como exposto no capítulo anterior.
} 
imersos textos, linguagens e códigos, no caldo cultural que propõe o etólogo estariam imersos os memes, unidades culturais capazes de gerar cópias de si. Essa capacidade nos permite pensar os memes como elementos estruturadores da cultura, assim como a semiosfera é geradora de estruturalidade (HENN, 2014, p. 41). Nesse sentido, a cultura seria o espaço no qual esses entes auto-organizadores se dinamizam na interação com os outros elementos "dispersos" no ambiente semiosférico/cultural: "a cultural digital, no interior da qual se intensifica o conceito de meme, é um campo de materialização de vários processos auto-organizacionais" (ibidem, p. 43, tradução nossa ${ }^{42}$ ).

$\mathrm{Na}$ analogia com a genética, entretanto, Dawkins postula que, apesar de ser conservadora, a transmissão cultural pode dar origem a uma forma de evolução, o que na perspectiva semiótica da cultura seria um equívoco:

Os sistemas culturais não são essencialmente conservadores: o que caracteriza as culturas é justamente a constante tensão entre a conservação e a mudança (LOTMAN, 1999). Conservação total gera uma redundância estagnadora, que impede suas próprias replicações estruturais. A transformação total evoluciona até a entropia máxima: o caos informativo. (HENN, 2014, p. 44, tradução nossa ${ }^{43}$ )

Desse modo, apesar de que possamos vislumbrar que na teoria de Dawkins há um germe para se pensar os memes por seu aspecto de regularidade, de estrutura (como diria Lotman), por compreender o processo cultural como algo que se conserva em seu devir (o que pelo menos busca esse estado de conservação), Dawkins ignora de certa maneira a transformação (deformação) do texto, fazendo-nos assim compreender que, para ele, a evolução cultural se desenvolve por transmissão em vez de comunicação ou semiose, como Henn nos mostra em sua leitura do meme de Dawkins a partir de Lotman:

Os memes, nestes processos dinâmicos da cultura, se diversificam e promovem disputas intensas na semiosfera - o ambiente criado pelos textos culturais entendidos como sistemas de signos. A semiosfera está composta por fronteiras nas quais as máquinas de sobrevivência dos memes operacionalizam estratégias de ação e permanência. Estas fronteiras exploram hoje um mundo em rede, altamente convergente, transmediático e instantâneo. A própria memória se reconfigura neste processo. Estruturas arquetípicas de memes se reinventam enquanto novas mutações surgem [...].(HENN, 2014, p. 46, tradução nossa ${ }^{44}$ )

\footnotetext{
${ }^{42}$ [...] a cultura digital, en el interior de la cual se intensifica el concepto de meme, es un campo de materialización de varios procesos auto-organizacionales [...]."

43 "Los sistemas culturales no son esencialmente conservadores: lo que caracteriza a la cultura es justamente la constante tensión entre la conservación y el cambio (LOTMAN, 1999). Conservación total genera una redundancia estancadora, lo que impide sus propias replicaciones estructurales. La transformación total evoluciona hacia la entropía máxima: el caos informativo."

44 "Los memes, en estos procesos dinámicos de la cultura, se diversifican y promueven disputas intensas en la semiosfera - el ambiente creado por los textos culturales entendidos como sistemas de signos. La semiosfera está compuesta por fronteras en las cuales las máquinas de supervivencia de los memes operacionalizan estrategias de acción y permanencia. Estas fronteras explotan hoy en un mundo en red, altamente convergente,
} 
Trazer essa discussão para o nosso objeto permite-nos pensar, assim, as ocorrências meméticas da internet nessa dinâmica entre a regularidade, que fazem delas meme, e ao mesmo tempo da transformação, isto é, a (res)significação da "não-cultura" (o que está "fora" da semiosfera digital/memética) em meme. Esse crescimento semiótico nas dinâmicas de comunicação e interação entre usuários seria a semiose, a ação do signo de acrescentar novos elementos de informação sobre o objeto, "que assim vai revelando pouco a pouco sua autêntica natureza ao observador/intérprete" (GORLÉE, 1992, tradução nossa ${ }^{45}$ ), que podemos entender como o processo de significação e apreensão do mundo.

Vejamos com mais detalhes como se dão essas dinâmicas, lançando luz ao meme como elemento nuclear da semiosfera, que estamos compreendendo aqui como sua regularidade, como uma formação de hábitos. O entendimento desse aspecto nos permitirá vislumbrar com mais clareza o que há de generalidade nos memes e como que, tomado como uma linguagem, o meme comporta uma concepção de mundo.

transmediático e instantáneo. La propia memoria se reconfigura en este proceso. Estructuras arquetípicas de memes se reinventan mientras nuevas mutaciones surgen $[\ldots]$."

45 “[...] que así va revelando poco a poco su auténtica naturaleza al observador/intérprete." 


\title{
CAPÍTULO 3. O MEME COMO LINGUAGEM
}

\author{
"Expressar uma ideia em uma linguagem e em seguida em outra \\ é repensá-la, num processo de compreendê-la de outro modo ${ }^{46,}$
}

Floyd Merrell

"Separar o homem do espaço das línguas, dos signos, dos símbolos é tão impossível quanto arrancar-lhe a pele que o cobre” Jorge Lozano

"Toda compreensão é prenhe de resposta" Mikhail Bakhtin

Explorados os conceitos de cultura, semiosfera e meio como extensão da consciência, podemos partir do pressuposto de que a internet pode operar como um espaço semiótico, um ambiente cultural, no qual as linguagens são possíveis, sendo também o que alimenta e estrutura esse espaço. Posto isso, esse capítulo tem como objetivo explorar e discutir a hipótese de que o meme pode ser tomado como uma linguagem que se encontra nesse ambiente e que também o organiza.

Como dito anteriormente, a provocação que nos moveu a entender o meme como linguagem partiu da curiosidade ao observar que, em espaços da internet, como fóruns e redes sociais, mensagens estariam se organizando de um modo particular, recebendo essas diversas ocorrências o mesmo nome: meme. Outro fato observado foi que, por meio dessas formas organizadas e regulares, os indivíduos podiam compartilhar opiniões, críticas e experiências, ou seja, o meme conformava também um modo de comunicar, uma maneira de externalizar um pensamento, de expressar uma compreensão do mundo. Por fim, uma terceira observação realizada em um momento inicial da pesquisa era o fato de essa forma de expressão se dar por meio da ressignificação de uma informação. Assim, cada ocorrência memética se dava como um feixe de releituras de uma imagem, um vídeo ou um texto verbal, com isso cedendo

\footnotetext{
${ }^{46}$ Floyd Merrell a partir do pensamento de Iuri Lotman.
} 
novos sentidos a esses textos, de forma expansiva, repetitiva e coletiva, parecendo ser este aspecto o que havia de regular em todas as ocorrências.

Nesse sentido, partindo dessas observações, buscamos aqui entender o meme como linguagem destacando três pontos que veremos no decorrer deste capítulo: primeiro por seu caráter "normativo", de formação de regras de funcionamento que os caracterizam enquanto tais; também por seu aspecto social, de partilha, o que faz dele forma de comunicar: se pensamos o meme como linguagem, podemos imaginar a existência de "falantes" dessa linguagem; e em terceiro lugar o caráter do meme que diz respeito à maneira de dar sentido (ou novos sentidos) às coisas do mundo, de ressignificar informações, imagens, vídeo, textos.

De modo algum esses três aspectos estão separados, na realidade, um implica o outro. Expomos separadamente essas três qualidades da linguagem do meme mais como forma de clarear nosso processo heurístico e construtivo do nosso objeto de pesquisa, o meme como uma linguagem da internet. Nesse sentido, esse capítulo visa lançar luz a como essa linguagem, a partir da formação de hábitos, leis de ação, orienta coletivamente concepções sobre o mundo, delimitando também uma comunidade linguística interpretativa que, inserida em um contexto cultural, isto é, em uma semiosfera, compreende os textos produzidos nas dinâmicas comunicativas mediadas pela internet.

\subsection{Signo, linguagem e pensamento}

Como vimos, o meio de comunicação se estabelece enquanto um espaço de cultura quando entendido para além de seu aspecto de suporte físico, mas também como uma esfera da mente. Desse modo, a internet, ou qualquer outra tecnologia que compreendemos como meio de comunicação, para ser entendida enquanto tal (algo além de eletricidade, cabos, telas, luz e processos mecânicos) pode ser tomada como uma extensão da consciência. O que nos permite essa compreensão, como elucidado por Martino, é que tanto no meio quanto nos processos da consciência o que está em jogo são signos (MARTINO, 2000, p. 111). E a linguagem, por sua vez, definida de maneira mais direta, seria o uso desses signos, de modo que essa utilização envolva o conhecimento ou a consciência da relação de significação, que é potencialmente infinita (MARITAIN apud DEELY, 1995, p. 141). 
Conforme o filósofo americano Charles Sanders Peirce, o signo pode ser entendido da seguinte maneira, partindo de dois trechos dos Collected Papers selecionados por Santaella (2008, p. 12):

Um signo, ou representamen, é aquilo que, sob certo aspecto ou modo, representa algo para alguém. Dirige-se a alguém, isto é, cria na mente dessa pessoa, um signo equivalente, ou talvez, um signo mais desenvolvido. Ao signo assim criado, denomino interpretante do primeiro signo. $\mathrm{O}$ signo representa alguma coisa, seu objeto. Representa esse objeto não em todos os seus aspectos, mas com referência a um tipo de ideia que eu, por vezes denominei fundamento do representamen. (CP $2.228^{47}$, grifo do autor)

Defino um Signo como qualquer coisa que, de um lado, é assim determinada por um Objeto e, de outro, assim determina uma ideia na mente de uma pessoa, esta última determinação, que denomino o Interpretante do signo, é, desse modo, mediatamente determinada por aquele Objeto. Um signo, assim, tem uma relação triádica com o seu Objeto e com seu Interpretante. (CP 8.343 , grifo do autor)

É válido observar que, nessa relação triádica (genuína), signo, objeto e interpretante, são todos de natureza sígnica, isto é, os três são signos, sendo assim, o que os diferencia é o papel lógico que exercem nessa relação de três posições (SANTAELLA, 2008, p. 17). Desse modo,

um Signo, ou representamen, é um Primeiro que está em uma relação genuína triádica com um Segundo, chamado seu Objeto, de tal modo que é capaz de determinar que um Terceiro, chamado seu Interpretante, assuma a mesma relação triádica com seu Objeto, a que tem o próprio Signo com mesmo Objeto" (CP 2.274, grifo do autor, tradução nossa ${ }^{48}$ ).

Fazemos aqui também uma especificação do termo interpretante nessa conceituação de signo. Quando Peirce se refere a uma ideia na mente de "uma pessoa", o faz para facilitar a compreensão da sua noção de signo. O interpretante determina uma ideia em uma mente, existencial ou potencial (portanto não necessariamente de uma pessoa). Assim, um signo não é "um ente vazio e passivo dependente de um ego individual" que venha acrescentar algo de que ele carece: o interpretante (SANTAELLA, 2008, p. 63). Na realidade, o interpretante é uma propriedade do signo, exista um ato interpretativo particular que o atualize ou não, "[o interpretante] é uma criatura do signo que não depende estritamente do modo como uma mente subjetiva singular possa compreendê-lo" (idem). Esse interpretante a que se refere Peirce seria uma potencialidade de gerar interpretações inscrita no signo, portanto, essa

\footnotetext{
47 "CP" refere-se à coleção The Collected Papers of Charles Sanders Peirce. A notação indica o número do volume, seguida por um ponto, e por fim o número do parágrafo.

48 "A Sign, or Representamen, is a First which stands in such a genuine triadic relation to a Second, called its Object, as to be capable of determining a Third, called its Interpretant, to assume the same triadic relation to its Object in which it stands itself to the same Object."
} 
especificação que ele faz não significa a não existência de atos interpretativos particulares e individuais: "A interpretação de um signo por uma pessoa é primariamente uma atitude de contemplação, alerta e observação do interpretante ou interpretantes que o signo é capaz de produzir" (idem).

Assim, é signo tudo aquilo que pode mediar e levar diante da mente uma ideia, aquilo que for capaz de manifestar algo para um terceiro (BARRENA, 2001). Para Peirce, o nosso pensamento consiste em signos, desse modo "qualquer objeto, fenômeno ou acontecimento cognoscível (CP 8.177) - isto é, perceptível ou imaginável - pode ser um signo" (GORLÉE, 1992, tradução nossa ${ }^{49}$ ). Entendemos a linguagem, assim, como uma mediação entre pensamento (interpretante) e mundo (objeto).

\subsection{Meme e a terceiridade do signo}

A breve noção inicial de signo que expusemos no tópico anterior nos servirá de partida para compreender diversos pontos que pretendemos abordar neste capítulo, a começar pelas três categorias que Peirce estabelece, às quais podemos associar os três correlatos do signo: a primeiridade (representamen), a secundidade (objeto) e a terceiridade (interpretante).

Peirce identifica, assim, o pensamento com essas três categorias, elaboradas na fenomenologia ou faneroscopia, e que correspondem a maneiras de experimentar o mundo e a realidade por meio dos signos. As três consistem em formas de classificar características do faneron: "o total coletivo de tudo que está de algum modo presente na mente, não obstante se isto corresponde a qualquer coisa real ou não" (CP 1.284, tradução nossa ${ }^{50}$ ), i.e., tudo aquilo que se manifesta para a mente indistintamente, portanto, a abordagem fenomenológica de Peirce não se preocupa com a realidade do fenômeno, mas apenas com a sua manifestação, sua aparência (GOMES, 2013, p. 270). Posto isso, passemos à compreensão das categorias.

No que diz respeito à classe de fenômenos que se apresentam enquanto primeiridade encontram-se entes que existem independentemente por si mesmos, algo que possui "qualidade de sensação" (WALTHER-BENSE, 2010, p. 2). A compreensão dessa categoria nos parece um pouco árdua, talvez justamente pelo fato de corresponder

\footnotetext{
49 "Para Peirce no había ninguna duda de que cualquier objeto, fenómeno o suceso «conocible» (CP: 8.177, s.a.) - es decir, perceptible o imaginable- puede ser un signo."

50 "I mean the collective total of all that is in any way or in any sense present to the mind, quite regardless of whether it corresponds to any real thing or not."
} 
aos fenômenos que "antecedem" o entendimento, isto é, a mediação. Podemos esclarecê-la melhor a partir do exemplo que se encontra na explicação de Floyd Merrell:

A primeiridade por si só não é uma qualidade concreta (como, por exemplo, a sensação da cor e a forma de uma maçã que talvez estivéssemos percebendo neste momento). Não é mais que uma mera possibilidade, sem partes definíveis, sem antecedentes nem consequências. É simplesmente o que é, sem que alguém seja plenamente consciente da qualidade que é. Peirce se refere à Primeiridade como pura liberdade, espontaneidade, originalidade, a possibilidade de que aconteça algo novo. É, por exemplo, quando o instante em que chego a perceber um livro azul sobre a mesa, o que vejo, ainda sem consciência do que vejo, é simplesmente uma mancha de certa cor antes que a tenha denominado "livro". É nada mais que uma qualidade, sem conexão com tudo mais que haja ao seu redor. É só uma possibilidade que, em algum momento, talvez possa formar parte de uma classificação determinada de maneira que entre em inter-relação semiótica com outros signos possíveis. (MERRELL, 2001, tradução nossa ${ }^{51}$ )

Desse modo, a noção de que os fenômenos de primeiridade existem por si mesmos explica-se por seu caráter de esponteneidade, instantaneidade, imediatismo, presentidade. Um fenômeno de primeiridade é o que é, de maneira direta, não tem continuidade, nem lógica, isto é, não é nada além do que ele mesmo apresenta (GORLÉE, 1992). A primeiridade, como o termo já diz, é um "primeiro", sendo assim, indica a ausência de um "outro" (um "segundo"), não possuindo assim relação com qualquer outra coisa (GOMES, 2013, p. 271-272).

A alteridade, a existência de um outro, um segundo, já é da ordem dos fenômenos de secundidade, por assim dizer, um outro que força a sua presença à nossa existência, algo à parte de nós mesmos, "sem que (ainda) o tenhamos podido classificar ou descrever" (MERRELL, 2001, tradução nossa ${ }^{52}$ ). Nesse sentido, a secundidade é um evento que ainda não pode ser conceitualizado, algo que simplesmente existe, independentemente das nossas opiniões ou expectativas.

Enquanto a primeiridade significa unidade indivisível, a secundidade implica a ideia dinâmica de alteridade, de consciência bipolar, a experiência de açãoestímulo e reação, de causa e efeito, de mudança e resistência à mudança. A ideia dupla de bater e apanhar encarna perfeitamente a secundidade, pois contém os elementos de comparação, contraste, interação e luta. Um primeiro é inapreensível, "só algo que poderia realizar-se", uma potencialidade ou possibilidade; já um segundo é um fato concreto, "um acontecimento... algo

\footnotetext{
51 “La Primeridad de por sí no es una cualidad concreta (como, por ejemplo, la sensación del color y la forma de una manzana que quizás estuviéramos percibiendo en este momento). No es más que una mera posibilidad, sin partes definibles, sin antecedentes ni consecuencias. Es simplemente lo que es, sin que alguien sea plenamente consciente de la cualidad que es. Peirce se refiere a la Primeridad como pura libertad, espontaneidad, originalidad, la posibilidad de que acontezca algo nuevo. Es, por ejemplo, cuando en el instante en que alcanzo a percibir un libro azul sobre la mesa, lo que veo, aún (todavía) sin consciencia de lo que veo, es sencillamente una mancha de cierto color antes de que la haya clasificado como una forma rectangular de color azul, y sin que la haya denominado 'libro'. Es nada más una cualidad, sin conexión con todo lo demás que hay a su alrededor. Es sólo una posibilidad que, en algún momento futuro, quizás pueda formar parte de una clasificación determinada de manera que entre en interrelación semiótica con otros signos posibles."

52 " [...] sin que (todavía) lo hayamos podido clasificar o describir."
} 
que ocorre realmente" (CP 7.538). [...] enfrentamos a realidade, valendo-nos da secundidade e neste processo que ganhamos experiência de vida. [...] A secundidade entra em jogo cada vez que fazemos um esforço, tomamos uma decisão, descobrimos algo, nos orientamos no espaço ou no tempo, ou quando algo nos pega de surpresa (CP 5.52 - 5.58). (GORLÉE, 1992, tradução nossa ${ }^{53}$ )

Essa categoria compreende, assim, as experiências que dependem do espaço e do tempo, eventos factuais, objetos concretos e singulares (WALTHER-BENSE, 2010, p. 2-3). Diz respeito ao que poderíamos chamar de fatos brutos. A secundidade faz referência a um "aqui e agora" em relação com o passado, isto é, está baseada no que se aprendeu em experiências passadas (GORLÉE, 1992).

Enquanto a primeiridade se caracteriza pela vaguidade e pela possibilidade de ser, a secundidade por sua forma concreta e existencial, a terceiridade estabelece-se como lei geral que proporciona continuidade. A terceiridade é a mediação, relação, "cria ordem a partir de caos" (idem). Podemos dizer que a terceiridade é o que viabiliza uma possibilidade se tornar um fato atual, e, portanto, caracteriza-se como mediação, relação entre um primeiro e um segundo: a "terceiridade [...] aproxima um primeiro e um segundo numa síntese intelectual, corresponde à camada de inteligibilidade, ou pensamento em signos, através da qual representamos e interpretamos o mundo" (SANTAELLA, 1983, p. 51). A essa categoria

[...] pertence tudo aquilo que é determinado por uma maneira de ser e por uma atividade espiritual consciente, que há que ser entendido sob os termos de pensamento, conhecimento, regularidade, coordenação, representação e comunicação, e entre os quais se deve incluir também o próprio signo como um representamen, como por vezes diz Peirce. "Pensar" sempre comparece como um sistema de três relações: 1.alguém que pensa, 2. o pensado, e 3. o pensar. (WALTHER-BENSE, 2010, p. 3, grifo da autora)

Nesse sentido, os fenômenos de terceiridade são aqueles que possuem ordem, que funcionam como lei, que levam ao estabelecimento de hábitos e generalidades:

Uma vez que se põe em relação aos fenômenos, as manifestações que se chocam contra a consciência (Secundidade), a mente, que possui uma "tendência à generalização que busca subsumir ao conceito um número maior de fenômenos, tornando-o, por isso mais geral” (IBRI, 1992, p. 14), faz exatamente isso. Sintetiza, generaliza, cria padrões e conceitos. E dessa forma aprende. (GOMES, 2013, p. 273)

\footnotetext{
53 “ Mientras la primeridad significa unidad indivisible, la segundidad implica la idea dinámica de alteridad, de conciencia bi-polar, la experiencia de acción-estímulo y reacción, de causa y efecto, de cambio y resistencia al cambio. La doble idea de pegar y ser pegado encarna perfectamente la segundidad, pues encierra los elementos de comparación, contraste, interacción y lucha. Un primero es inaprensible, «sólo algo que pudiera realizarse», una potencialidad o posibilidad; en cambio, un segundo es un hecho concreto, «un suceso... algo que ocurre realmente» [...] hacemos frente a la realidad, valiéndonos de la segundidad, y en este proceso hacemos experiencia de la vida. [...] La segundidad entra en juego cada vez que hacemos un esfuerzo, tomamos una decisión, descubrimos algo, nos orientamos en el espacio o en el tiempo, o cuando algo nos coge de sorpresa (CP:5.52-5.58)."
} 
Ressaltamos que, ao criar padrões e generalizar, podemos entender que os entes dessa categoria possuem um aspecto de continuidade, como mencionamos, que nos permite adotar determinadas atitudes em relação a fatos futuros. A terceiridade assim não pode ser imediata, uma vez que envolve certo tempo, não apenas porque é contínua, mas também "porque não pode ser contraída em um único instante", a terceiridade abarca a consciência de um processo (GORLÉE, 1992, tradução nossa ${ }^{54}$ ).

Desse modo, podemos entender a linguagem do meme como um fenômeno de terceiridade. Assinalamos que, entretanto, a primeiridade e secundidade do fenômeno não podem ser apagadas, dado que o meme também possui aspectos dessas duas categorias, pois elas não se isolam, não são estanques: "Nenhuma linha firme de demarcação pode ser desenhada entre diferentes estados integrais da mente, isto é, entre estados tais como sentimento [primeiridade], vontade [secundidade] e conhecimento [terceiridade]" (PEIRCE apud SANTAELLA, 1983, p. 53). Destacamos, contudo, seu aspecto de terceiridade, por sua regularidade, por se portar como lei e por englobar signos que sustentam nossa comunicação. A terceiridade diz respeito àquilo que é comunicável, produzindo efeitos físicos mediante uma ação lógica (ÁLVAREZ ${ }^{55}$ ).

Como exposto anteriormente, a linguagem pode ser entendida como um núcleo no interior da semiosfera, que também chamamos de "centro organizador". Esse centro pode ser entendido como o que caracteriza a "essência" do meme, isto é, o que faz de um fenômeno um meme. A essência, entretanto, não deve ser entendida como algo inerente às ocorrências que estamos chamando de meme. Como nos sugere o filósofo americano com a noção de terceiridade, podemos entender essa essência como relação, pois ele acreditava que os universais ou essências eram relações (de similitude) entre entes atuais, isto é, entre ocorrências. Peirce, portanto, não entende a essência como algo perpétuo, "dado pela eternidade", mas sim como uma lei ou um hábito, uma vez que para ele as essências são disposicionais (BEUCHOT, 2001).

O meme pode ser compreendido assim como um legi-signo, uma vez que uma lei é a propriedade que rege seu funcionamento sígnico, e como tal, "só toma parte na experiência ou tem existência concreta por intermédio de suas manifestações"

\footnotetext{
54 “ $[\ldots]$ porque no puede ser contraída en un único instante.”

${ }^{55}$ Referência: ÁLVAREZ, Larissa Guerrero. La subjetividad semiótica en Charles S. Peirce. Conferência dada no Seminario de profesores de la facultad de Filosofía Universidad Panamericana campus México. Disponível em

< https://www.academia.edu/1665195/La_subjetividad_semi\%C3\%B3tica_en_Charles_S._Peirce> acesso em 25/11/2014. Não consta a data de publicação no texto.
} 
(SANTAELLA, 2008, p. 101-102). A identidade de um legi-signo se dá assim pela margem de signos semelhantes a ele que é capaz de gerar. Cada exemplar que dá sentido ontológico para o legi-signo pode ser compreendido como um sin-signo, um signo com caráter de secundidade:

[Um sin-signo] é a "coisa ou acontecimento realmente existente, que funciona como signo" (Peirce 1955: 101,1903). Para ser sin-signo, [...] a "coisa ou acontecimento" deve ser um signo precisamente porque existe como uma coisa ou acontecimento individual. Um sin-signo depende tanto de um lugar como de um tempo, sempre ocorre em um certo contexto [...]. (GORLÉE, 1992, tradução nossa $^{56}$ )

As ocorrências meméticas, portanto, ainda que pareçam completamente diferentes, guardam entre si uma relação de semelhança que opera como atualizações da possibilidade (primeiridade) de determinada imagem, vídeo, o texto se tornar um meme. Assim, se tomarmos o grupo montagens (Figura 2), o conjunto de frases no Twitter (Figura 3) e a série de vídeos (Figura 4) mostrados a seguir, temos aqui ocorrências, atuais e concretas, determinadas no tempo e no espaço, que funcionam como individuais correlatos a uma generalidade que chamamos de meme da internet.

\footnotetext{
${ }^{56}$ Tradução nossa do trecho: [...] es la «cosa o suceso realmente existente, que funciona como signo» (Peirce [32] 1955: 101, hacia 1903). Para ser sinsigno, [...] la «cosa o suceso» debe ser un signo precisamente porque existe como una cosa o suceso individual. Un sinsigno depende tanto de un lugar como de un tiempo, siempre ocurre en un cierto contexto [...].
} 
Figura 2 - Meme Desespero da Veja.

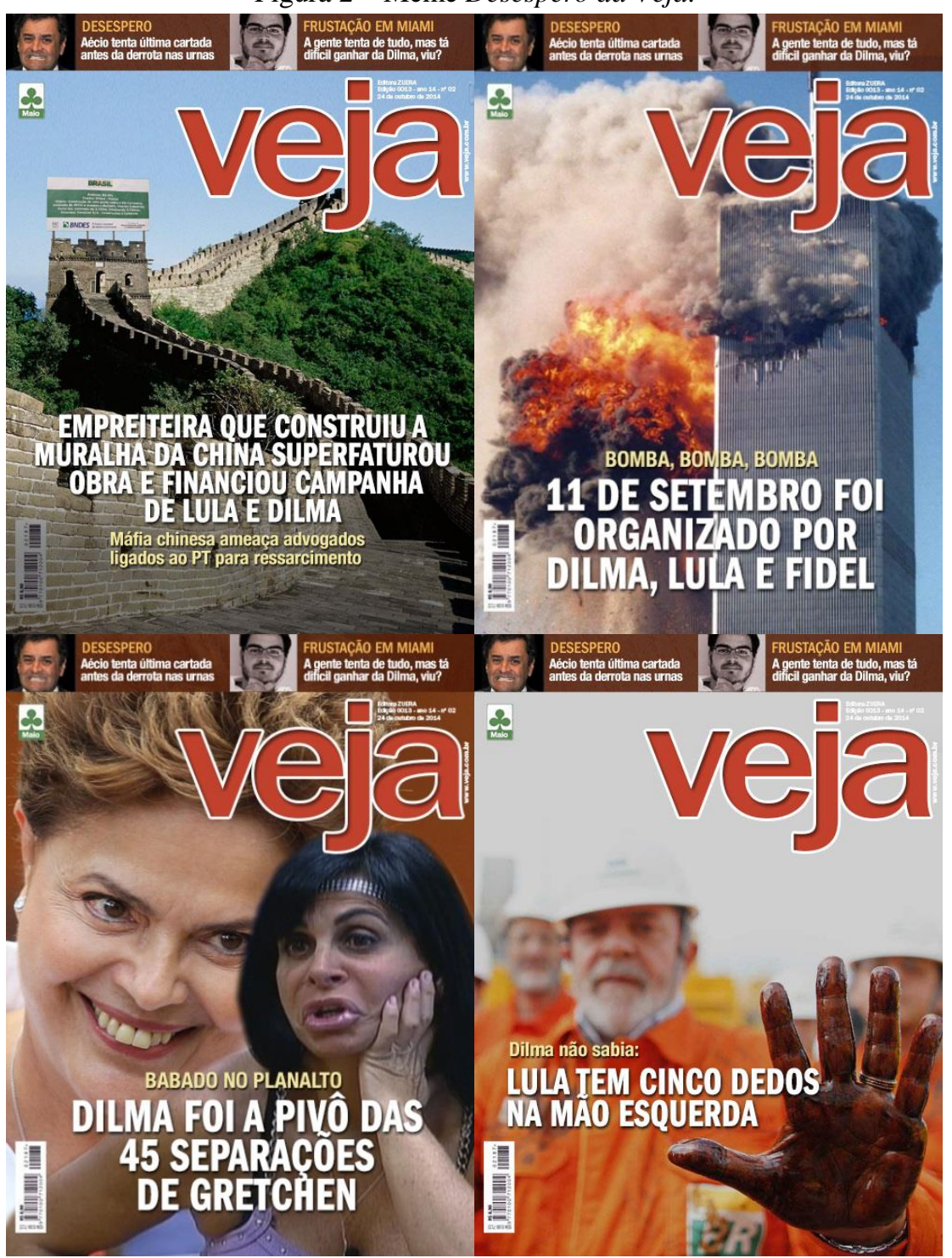

Fonte: desesperodaveja.tumblr.com ${ }^{57}$

${ }^{57}$ < desesperodaveja.tumblr.com> Acesso em 27/11/2014 
Figura 3 - Meme "Você teria coragem".

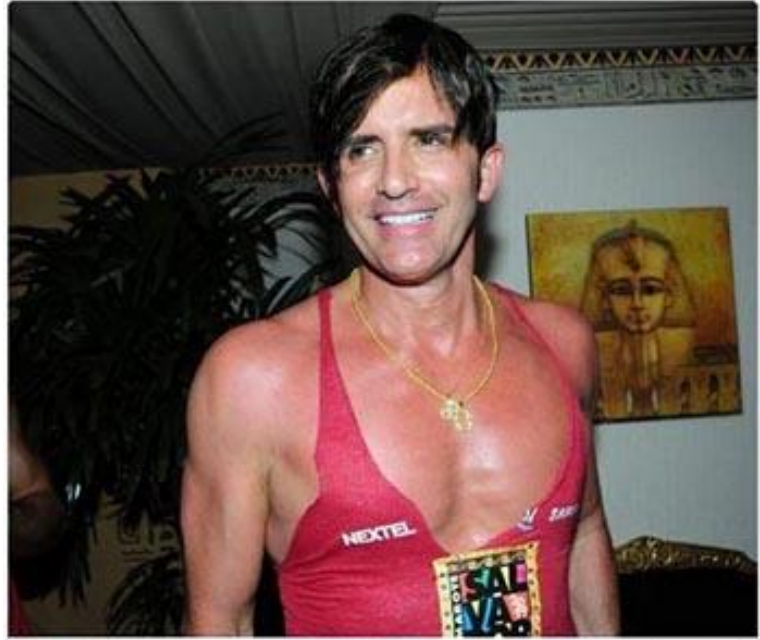

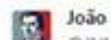

1. elvMirands.

vc teria coragem de atendido por um médico q se veste assim? 18: 23.6 set 2014

114 Retwetrs 59 curTrav

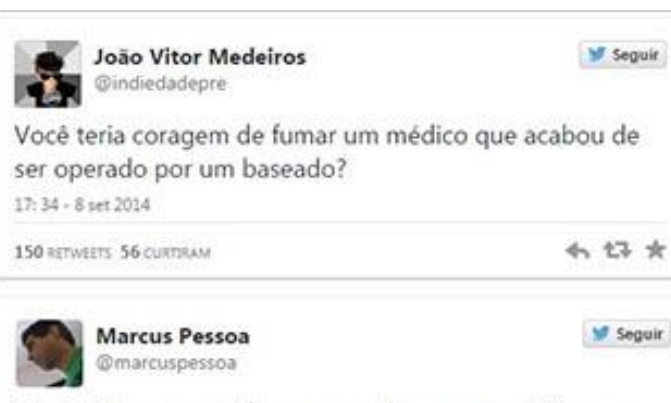

Vocề teria coragem de ser operado por um médico que năo sabe a diferença entre o charm e o funk? 18: $06-6$ set 2014

51 ketwats 26 curnuy \& $27 \star$

Dibre

Cibotadouglas

Você teria coragem de ser operado por um médico que coloca o arroz por cima do feijão? 18: $02-6 \operatorname{set} 2014$

65 xtrwats 33 chenzes 4 $27 \star$

Fonte: adnews.com.br ${ }^{58}$

Figura 4 - Meme Marmota Dramática.
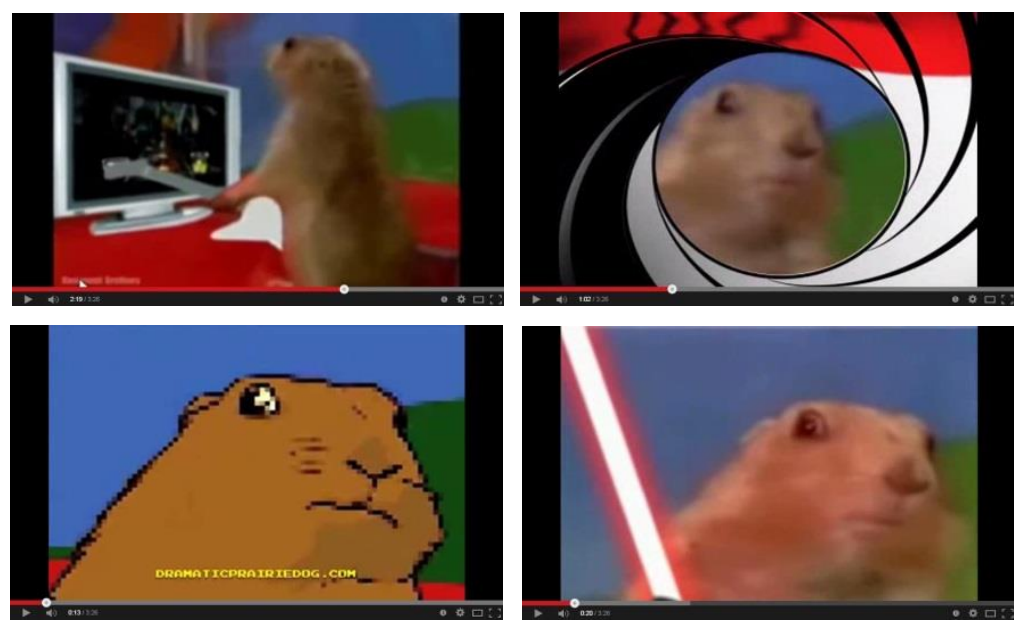

Fonte: youtube.com ${ }^{59}$

A relação entre as três ocorrências revela a propriedade do meme de agir como lei, como uma linguagem, no âmbito da terceiridade. Posto de forma direta (o que veremos com mais detalhes a seguir), o que as torna similares é o fato de se configurarem como paródia de algo e se determinarem pela repetição frequente dessas

\footnotetext{
$58<$ http://www.adnews.com.br/internet/campanha-contra-a-maconha-vira-piada-na-web> Acesso em $27 / 11 / 2014$

${ }^{59}<$ https://www.youtube.com/watch?v=eV_djHsI134> Acesso em 27/11/2014.
} 
releituras. Ou seja, essas são as regras que guiam o devir de um meme por suas ocorrências.

As capas da revista são paródias da capa do dia 29 de outubro de 2014 (Fgura 5), veiculada logo depois do resultado da pesquisa Datafolha que indicava o avanço da candidata Dilma Rousseff nas pesquisas para o segundo turno das eleições presidenciais do mesmo ano ${ }^{60}$. Já os tweets, que também funcionam como paródia, representam a reação dos usuários da rede social a um anúncio publicado no perfil do Facebook da deputada federal Marisa Lobo, criado pelo movimento Brasil Sem Drogas ${ }^{61}$ (Figura 6). Por fim, os vídeos do terceiro grupo originam-se do trecho de um programa japonês, no qual um cão-da-pradaria lança um olhar repentino para a câmera. Aos menos de dez segundos de vídeo, foi adicionado um áudio retirado da trilha sonora do filme Young Frankenstein, conferindo ainda mais dramaticidade à cena. Essa criação ${ }^{62}$ ganhou diversas versões, em forma de montagens, edições e encenações.

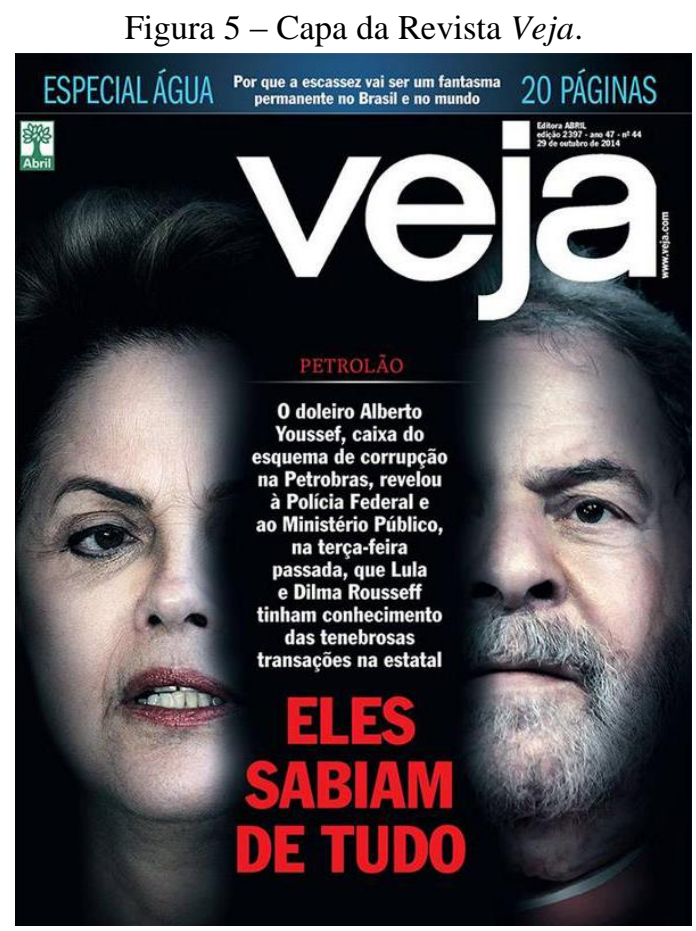

Fonte: agorafazsentido.com.br ${ }^{63}$

\footnotetext{
${ }^{60}$ Fonte: http://www.pragmatismopolitico.com.br/2014/10/site-ironiza-desespero-da-veja-como-capasfantasiosas-em-vespera-de-eleicao.html Acesso em 27/11/2014.

${ }^{61}$ Fonte: < http://oglobo.globo.com/sociedade/tecnologia/campanha-contra-legalizacao-da-maconha-no-brasilvira-meme-na-web-13878386> Acesso em 27/11/2014

$62<$ https://www.youtube.com/watch?v=a1Y73sPHKxw> Acesso em 19/1/2014.

${ }^{63}<$ http://www.agorafazsentido.com.br/2014/10/os-melhores-memes-do-desespero-da.html > Acesso em $27 / 11 / 2014$
} 
Figura 6 - peça da campanha do movimento Brasil Sem Drogas.
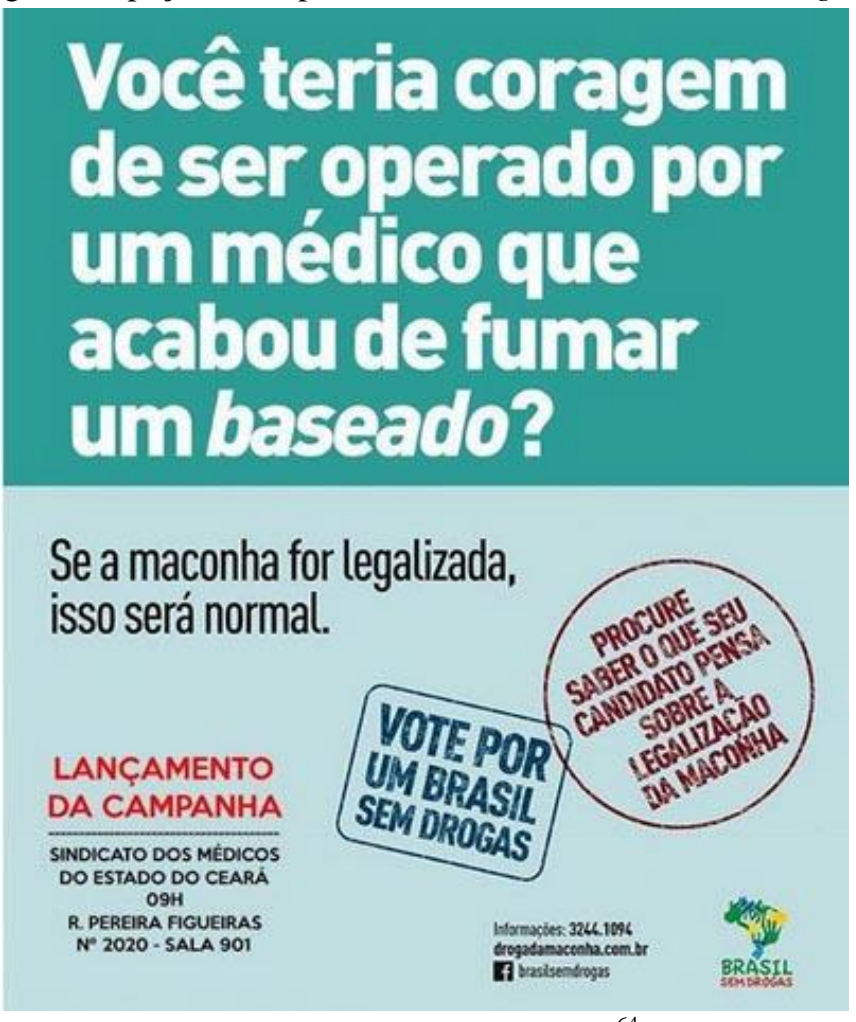

Fonte: Fonte: adnews.com.br ${ }^{64}$

O que observamos nessas ocorrências é uma regularidade, e é essa regularidade que chamamos de meme - o meme-linguagem ou o meme-conceito - e que nos permite também nomear cada ocorrência individual também como meme - os memes: o meme Desespero da Veja, o meme "Você teria coragem”, o meme Marmota Dramática. Essa regularidade como vimos não é dada e imutável. O meme estabelece-se como linguagem pela formação de hábitos. Podemos compreender a linguagem (e a cultura que está em constante diálogo com ela) como um conjunto de hábitos que dão sentido à existência (secundidade) das coisas, que permitem a mediação do pensamento e do mundo, que permitem a atualização de possibilidades como vimos acima. O hábito pode ser entendido assim como uma tendência, uma disposição para atuar de determinada forma:

Peirce define o hábito como uma especialização da natureza do homem tal que se comportará, ou tenderá a se comportar, de uma maneira que possa tornar presente em si mesmo um carácter geral descritível. Os hábitos, escreve Peirce por volta de 1907, se distinguem da mera disposição em que foram adquiridos como consequência do princípio (tenha sido formulado explicitamente ou não) de que um comportamento da mesma classe múltiplas

\footnotetext{
${ }^{64}<$ http://www.adnews.com.br/internet/campanha-contra-a-maconha-vira-piada-na-web> Acesso em $27 / 11 / 2014$
} 
vezes reiterado produz uma tendência real a comportar-se de forma similar sob circunstâncias similares no futuro. (BARRENA, 2001, tradução nossa ${ }^{65}$ )

O hábito se constitui, portanto, pela repetição de ações. Podemos entender assim que a repetição de condutas dos frequentadores de fóruns e redes sociais tem configurado o que entendemos como meme da internet, bem como essa repetição é o que permitirá entender ocorrências futuras também como memes. Como também nos mostra Sara Barrena, os hábitos constituem uma ponte que une o passado com os novos caminhos e, para crescer, para criar, é preciso partir do passado (idem). A ideia de que há crescimento e transformação "ameniza" a noção de lei como algo cristalizado, no entendimento do meme como linguagem, pois

[...] a mente não está sujeita à 'lei' no mesmo sentido rígido em que está a matéria. Ela apenas experimenta forças suaves que meramente a torna suscetível a agir, e não poderia ser de outra forma. Sempre permanece uma quantidade de espontaneidade arbitrária em sua ação, sem a qual estaria morta. (CP 6.148, tradução nossa ${ }^{66}$ )

Assim, o que entendemos aqui como uma possível "gramática" do meme, ou mesmo a ideia de um centro organizador no interior de uma semiosfera, não fazem do meme uma estrutura rígida, mas simplesmente uma forma guia de articular o pensamento, que nos permite entender e expressar nossas impressões de eventos, imagens, pessoas ou fatos de nossa vida cotidiana de determinada maneira, sujeita a transformações e sempre aberta à possibilidade criativa da mente, ao crescimento semiótico.

Podemos entender os hábitos que constituem o meme como uma pluralidade de usos dessa linguagem, o que nos permite vislumbrar uma aproximação da formação de hábito com a ideia de jogos de linguagem de Ludwig Wittgenstein. Vejamos como essa aproximação pode trazer novos elementos para a nossa compreensão do meme como uma linguagem.

\footnotetext{
65 "Peirce define el hábito como una especialización de la naturaleza del hombre tal que se comportará, o tenderá a comportarse, de una manera que pueda presentar en sí misma un carácter generalmente descriptible. Los hábitos, escribe Peirce alrededor de 1907, se distinguen de la mera disposición en que han sido adquiridos como consecuencia del principio (se haya formulado explícitamente o no) de que un comportamiento de la misma clase múltiples veces reiterado produce una tendencia real a comportarse de forma similar bajo circunstancias similares en el futuro."

66 " $[\ldots]$ the mind is not subject to "law" in the same rigid sense that matter is. It only experiences gentle forces which merely render it more likely to act in a given way than it otherwise would be. There always remains a certain amount of arbitrary spontaneity in its action, without which it would be dead."
} 


\subsection{O meme e seus jogos de linguagem}

A noção de jogos de Linguagem aparece na filosofia de Wittgenstein em um segundo momento, em oposição a um "primeiro" Wittgenstein autor da obra Tractactus Logicus-philosophicus. De modo breve, o que propunha o filósofo austríaco nesse livro inicialmente era "estabelecer um limite ao pensar, ou melhor, à expressão do pensamento" (WITTGENSTEIN apud HACKER, 1993, p. 161, tradução nossa ${ }^{67}$ ). Para ele, somente na linguagem esse limite poderia ser estabelecido e o seu primeiro livro concentrou-se, assim, em delinear a natureza essencial de qualquer representação possível (idem). Procurando estabelecer os limites do dizível, para esse primeiro Wittgenstein as proposições só teriam sentido se fossem representações do estado das coisas, o que reduzia a significação aos processos de denominação. Ao final do Tractatus, Wittgenstein se vê obrigado a rejeitar sua própria obra, uma vez que a asseveração de que todo nome deve necessariamente ter referência para que a linguagem possa ter sentido é uma afirmação que vai contra o que ela mesma está propondo, produzindo, assim, um contrassenso (DALL'AGNOL, 2012, p. 19-21).

Não nos ateremos ao Wittgenstein do Tractatus Logico-philosophicus, contudo mostramos aqui rapidamente seu percurso filosófico porque ele serviu de ponto de partida para um segundo Wittgenstein, marcado pela obra Investigações Filosóficas, e cujo pensamento nos interessa para o recorte do meme como linguagem. A diferença entre esses "dois Wittgensteins" é que o segundo abandona a ideia de que a "estrutura da realidade determina a estrutura da linguagem", sugerindo que ocorre justamente o contrário: "nossa linguagem determina a concepção que temos da realidade, porque através da linguagem é que são vistas as coisas” (PEARS, 1988, p. 15).

Disto depreende-se que a linguagem pode ser entendida como a nossa maneira de acessar o real, de compreender o mundo. Destacamos também que, nesse segundo momento de seu pensamento, Wittgenstein reconhece alguns equívocos como a exigência que havia no Tractatus de uma isomorfia entre linguagem e mundo e a identificação do sentido de uma proposição com o seu valor de verdade $^{68}$ (DALL'AGNOL, 2012, p. 33), que coloca como função da linguagem somente a descrição do mundo. A partir das Investigações Filosóficas, Wittgenstein reconhece que

\footnotetext{
67 "[...] to set a limit to thought, or rather to the expression of thoughts."

${ }^{68}$ Para o primeiro Wittgenstein, a verdade ou falsidade de uma proposição é dada por uma comparação direta com a realidade (DALL'AGNOL, 2012, p. 17).
} 
há uma profusão de usos para a linguagem e compreende que o sentido de uma palavra reside justamente nesses usos que fazemos dela e não nessa relação de correspondência necessária entre a palavra e o seu referente.

Nesse sentido, a linguagem pode ser entendida como uma "amálgama de usos, atos particulares compondo uma pluralidade fluida" (SILVA, 2012), que vislumbramos aqui como os atos concretos e particulares (entes atuais) de que nos falava Peirce. Esses usos e as atividades a eles ligadas podem ser chamados de jogos de linguagem (WITTGENSTEIN, 1999, §7):

Quantas espécies de frases existem? Afirmação, pergunta e comando, talvez? - Há inúmeras de tais espécies, inúmeras espécies diferentes de emprego daquilo que chamamos de "signo", "palavras", "frases". E essa pluralidade não é nada fixo, um dado para sempre, mas [...] novos jogos de linguagem, como poderíamos dizer, nascem e outros envelhecem e são esquecidos. (Uma imagem aproximada disso pode nos dar as modificações da matemática).

O termo "jogo de linguagem" deve aqui salientar que o falar da linguagem é uma parte de uma atividade ou de uma forma de vida.

Imagine a multiplicidade dos jogos de linguagem por meio destes exemplos e outros:

Comandar, e a agir segundo comandos -

Descrever um objeto conforme a aparência ou conforme medidas -

Produzir um objeto segundo uma descrição (desenho) -

Relatar um acontecimento -

Conjeturar sobre o acontecimento -

Expor uma hipótese e prová-la diagramas -

Apresentar os resultados de um experimento por meio de tabelas e

Inventar uma história; ler -

Representar teatro -

Cantar uma cantiga de roda -

Resolver enigmas -

Fazer uma anedota; contar -

Resolver um exemplo de cálculo aplicado -

Traduzir de uma língua para outra -

Pedir, agradecer, maldizer, saudar, orar.

- É interessante comparar a multiplicidade das ferramentas da linguagem e seus modos de emprego, a multiplicidade das espécies de palavras e frases com aquilo que os lógicos disseram sobre a estrutura da linguagem (E também o autor do Tractatus Logico-philosophicus.) (WITTGENSTEIN, 1999, $\S 23)$.

Os jogos de linguagem seriam, portanto, usos intencionais da linguagem, que no meme recorrentemente se articulam em ações como comentar uma notícia, criticar, escarnecer alguém ou alguma situação, desabafar, emitir uma opinião, expressar um sentimento, vinculados a outras ações tais como postar, tweetar, compartilhar.

Esses jogos são múltiplos, variáveis e como observa Wittgenstein não são fixos, podem envelhecer como podem ser esquecidos, ou ainda, por outro lado, renovar-se no nascimento de outros jogos. Entendemos, assim, que os jogos consistem na ação da linguagem, isto é, a linguagem em uso. Neles, há algo de irrepetível, por possuírem um 
caráter contextual, mas ao mesmo tempo há algo que repete, que é regular, pois como todo jogo, os jogos de linguagem são uma atividade guiada por regras, por isso a analogia de Wittgenstein entre jogo e linguagem. Dessa forma, as regras da gramática (as regras dos jogos de linguagem) não determinam que lance (ou proferimento) será exitoso, mas sim aquilo que é correto ou faz sentido, definindo, assim, o próprio jogo, isto é, a própria linguagem (GLOCK, 1998, p. 225):

\begin{abstract}
Uma proposição constitui um lance ou uma operação no jogo da linguagem; seria destituída de significado na ausência do sistema que faz parte. Seu sentido é o papel que desempenha na atividade linguística em curso (PI §23, 199, 421;PG 130,172;BB 42). Assim como no caso dos jogos, os lances possíveis dependem da situação (posição no tabuleiro) e, para cada lance, certas relações serão inteligíveis, ao passo que outras serão rejeitadas. (GLOCK, 1998, p. 225-226)
\end{abstract}

Nesse sentido, o conteúdo exibido em determinada ocorrência que estamos chamando de meme, como os conjuntos apresentados acima, nas figuras 1 a 3 , estão dotados de sentido, na medida em que fazem parte de um sistema de regras, que chamamos de meme. A relação entre situação (contexto) e regras confere inteligibilidade às mensagens das imagens, textos, vídeos ou o que quer que componha determinada ocorrência memética. Desse modo, a articulação entre paródia e repetição (entendidas aqui como regras ou a regularidade do meme), em um contexto de uso na internet, com suas particularidades de circulação, além do conhecimento prévio do que originou o meme (como nos exemplos anteriormente dados: a capa da Veja, a campanha anti-drogas, o vídeo da Marmota Dramática), permite que essas releituras tenham sentido, e mais, que essa manifestação seja entendida como meme e não como uma obra literária, ou cinematográfica, ou arte. Pois, ainda que possa haver elementos de repetição (como ocorre em séries de TV) e paródia (como acontece na literatura, nas artes plásticas, entre outros), a forma como essas regras se articulam e se manifestam são específicas de uma maneira de compreender o mundo: o modo de dar sentido à experiência pelo meme. Podemos, assim, aproveitando a analogia de Wittgenstein, entender os jogos de linguagem do meme em comparação com o futebol. Há no futebol regras que o configuram como futebol, que permitem identificar uma partida como um jogo de futebol. Contudo, nenhuma partida de futebol é igual à outra. O mesmo se dá com os memes, suas "partidas", ocorrências, são diferentes e acontecem em determinada conjuntura, entretanto, todos esses jogos/partidas podem ser compreendidos como meme. 
Prosseguindo na analogia, podemos encarar os falantes como aqueles que sabem jogar o jogo, uma aprendizagem que decorre da própria prática, dos usos, "o fosso que separa a regra de sua aplicação é preenchido pelo treinamento ou pelo adestramento, a familiaridade, a prática do jogo" (NEVES, 2008, p. 38). Logo, compreender o mundo a partir dos memes exige certa "intimidade" com as dinâmicas estabelecidas nos jogos. Podemos acrescentar ainda que saber jogar um jogo é saber agir de acordo com suas regras, isto é, saber seguir as regras que conformam o jogo, uma ação que é essencialmente pública, isto é, seguir uma regra, seja uma lei de trânsito, uma norma de um jogo de futebol ou uma regra linguística, não pode ser feito privadamente. É possível identificar se alguém acredita estar seguindo uma regra realmente está seguindo ou não (DALL'AGNOL, 2012, p. 38):

\footnotetext{
Seguir uma regra é análogo a: seguir uma ordem. Somos treinados para isto e reagimos de um determinado modo. Mas que aconteceria se uma pessoa reagisse desse modo e uma outra de outro modo a uma ordem ao treino? Quem tem razão? Eis porque "seguir a regra" é uma práxis. E acreditar seguir a regra não é seguir a regra. E daí não podemos seguir regra privadamente; porque senão acreditar seguir a regra seria o mesmo que seguir a regra (WITTGENSTEIN apud NEVES, 2008, p. 49)
}

A partir dessa citação depreende-se que a linguagem é social e, como vimos, pública, uma vez que Wittgenstein levanta a questão de que não podemos seguir regras privadamente, as regras são guias compartilhadas da linguagem. Só é possível seguir uma regra quando aquilo que se toma como orientação foi anteriormente seguido, essa "mesmidade" do que foi seguido "só pode ser determinada por outro sujeito, defeso está que o próprio sujeito que alegar ter seguido a regra pode fazê-lo. Só o sujeito B [um segundo sujeito] que poderá averiguar se a regra foi seguida ou não" (VOLPATO DUTRA, 2012, p. 226). Nesse sentido, seguir uma regra é uma habilidade de participar de uma prática pública. O seu conhecimento e o "saber utilizar" as regras caracterizam um possível "falante" dessa linguagem. Dessa maneira, a natureza das regras não está em sua descrição, mas sim na competência de alguém que sabe "colocá-las em prática". Entender um jogo, portanto, e incluem-se aí os jogos de linguagem, é ter um know-how, cuja competência é fornecida no uso da regra, que "pode mostrar novos casos que contam como exemplo de seguir a regra" (ibidem, p. 227).

Podemos afirmar que as práticas adquirem estabilidade a partir de determinadas regras, entretanto as regras não asseguram um ponto de referência fixo, uma vez que "sempre admitem interpretações divergentes. O que realmente empresta estabilidade às práticas é a circunstância de concordarmos em nossas interpretações a respeito das 
regras" (PEARS apud SILVA, 2012). Ao mesmo tempo, são nessas práticas, na dinâmica de utilização, que as regras dos jogos de linguagem se constroem. Nesse sentido, podemos entender a dinâmica dos jogos de linguagem como formação de hábitos, comportamentos reiterados na prática (uso) que geram uma tendência a se comportar de maneira semelhante em situações futuras.

Posto isso, podemos delinear para o nosso recorte o que seria "gramaticalmente" um meme, na observação do que se tem chamado de meme na internet, partindo do entendimento que a estabilidade, a regularidade dessa prática, depende em certa medida da concordância de nossas interpretações das regras, dessa averiguação coletiva do seguir regras. Assim, ainda que alguns "puristas" venham a considerar como meme apenas manifestações nas quais há uma repetição de um modelo, vemos que essa noção foi estendida também a manifestações nas quais não há essa repetição da forma, mas sim uma repetição temática, somadas a um processo de apropriação e recriação (paródia).

Desse modo, podemos entender tanto uma repetição da forma (modelo) como uma repetição do conteúdo como meme, desde que estejam acompanhadas de uma reelaboração paródica, pois parece haver um $\operatorname{acordo}^{69}$ de que a repetição e a paródia configuram essa linguagem e seus modos de significar. O convencional, entretanto, está sempre sujeito a mudanças, em um dado momento histórico, pode ser que isto não mais configure o que se entende como meme, como ocorreu com o próprio meme de Dawkins que traz outra noção de meme que não esta. Para o nosso recorte, contudo, tomaremos repetição e paródia como o que há de regular nos memes. No próximo capítulo, veremos com mais detalhes como essas duas regras se configuram no meme da internet e com que outras categorias se relacionam. Antes disso, passemos à compreensão de outro aspecto dos jogos de linguagem, entendendo como ele se articula na ação da linguagem para a conformação do sentido.

\footnotetext{
${ }^{69}$ Depreendemos a existência desse acordo a partir de nossas experiências pessoais com o objeto e da observação do que se noticia como meme, em matérias que mostram, por exemplo, a reação da internet a determinado tema ou evento, além das classificações de algumas manifestações dadas pelos dois principais sites repositórios de memes nos quais baseamos esta pesquisa, o knowyourmeme.com e a memepedia do youpix.com.br.
} 


\subsection{Forma de vida e comunidade}

Como vimos na definição de jogo de linguagem de Wittgenstein, o autor salienta ainda que o falar da linguagem "é uma parte de uma atividade ou de uma forma de vida" (WITTGENSTEIN, 1999, §23, grifo nosso) e é deste último conceito que partiremos para lançar luz à ideia de uma comunidade linguística interpretativa do meme.

Esse conceito aparece nas obras de Wittgenstein sutilmente, e as fontes disponíveis para a sua interpretação são escassas (o termo aparece somente dez vezes na obra publicada do autor) e de difícil compreensão, havendo comentadores do filósofo austríaco que vão considerar até mesmo obscuras as passagens em que o termo "forma de vida" se apresenta (VELLOSO, 2003, p. 159; SPANIOL, 1990, p. 12), aparecendo ora no singular ora no plural. Por essa razão, a expressão possui interpretações diversas, das quais destacamos quatro sistematizadas por Araceli Velloso (2003) e que também aparecem no Dicionário de Wittgenstein de Hans-Johann Glock (1998): formas de vida (no plural) como "jogos de linguagem"; formas de vida (no plural) como "manifestações orgânicas"; formas de vida diferentes (no plural) como "culturas diferentes"; uma única forma, a forma de "vida humana" (no singular). Dentre essas, destacamos a interpretação que concebe a forma de vida mais próxima de uma ideia de cultura e vejamos o que ela nos sugere para a compreensão da ideia de comunidade.

Como posto anteriormente, os jogos de linguagem não são somente a manifestação de um conjunto de regras que podem ser descritas: são ações intencionais, e a compreensão do mundo a partir de uma linguagem em uso implica a articulação com outros elementos do contexto em que eles se inserem. Desse modo, tal qual um jogo, a linguagem está enraizada em instituições humanas, no que Wittgenstein chamou de forma de vida, que podemos compreender nos limites de nosso recorte como aquilo que “deve ser partilhado para que a comunicação seja possível” (DALL'AGNOL, 2012, p. 40). Wittgenstein entende, assim, a forma de vida como uma junção entre cultura, visão de mundo e linguagem (GLOCK, 1998, p. 173-174):

\footnotetext{
Wittgenstein enfatiza a ideia de que falar é uma atividade guiada por regras. Vai mais adiante, entretanto, sustentando que nossos jogos de linguagem estão "interligados" com atividades não linguísticas, devendo ser compreendidos dentro desse contexto. Isso não se aplica somente a nossos padrões discursivos reais. Com efeito, o melhor argumento para sustentar a tese de Wittgenstein de que o contexto não linguístico é essencial para a
} 
compreensão das atividades linguísticas é o fato de que jogos de linguagem fictícios só podem ser adequadamente avaliados quando é explicitado o modo como se enquadram nas práticas gerais da comunidade fictícia. "Imaginar uma linguagem é imaginar uma forma de vida" (PI, §§7, 19). Nos Livros azul e castanho (134), imaginar uma linguagem é o mesmo que imaginar uma cultura. Por conseguinte, uma forma de vida é uma formação cultural ou social, a totalidade das atividades comunitárias em que estão imersos os nossos jogos de linguagem. (GLOCK, 1998, p. 174)

Em um primeiro olhar sobre o conceito de forma de vida depreendemos dois aspectos que se imbricam. O primeiro é de que a linguagem é um fenômeno social (como já vimos, também público), dependendo de uma coletividade para existir. O segundo é que o sentido de algo é contextual, dependendo de fatores não linguísticos compartilhados em uma situação comunicativa, compartilhamento este que implica a existência de pelo menos um segundo sujeito, o que nos reenvia ao social da linguagem.

Podemos compreender que nem as regras nem os significados se sustentam fora de um contexto de uso. Não podemos pensar na linguagem do meme (ou qualquer outra linguagem) de modo isolado, isto é, que se constitua privadamente ou que seja alheia a uma forma de vida, incorrendo aí em um solipsismo: "a linguagem e o pensamento não residem no indivíduo, mas compõem uma 'forma de vida' aonde os indivíduos, partilhando de referenciais comuns, inserem-se" (SILVA, 2013, p. 140).

Para Wittgenstein, mesmo as referências a fenômenos que parecem ser os mais particulares como a dor ou a sensação de uma cor, só poderiam ser entendidas nos jogos de linguagem, isto é, o significado de termos como "dor" ou "vermelho" ou "alegria", por mais particulares que pareçam os seus entendimentos, até mesmo essas palavras, só tem sentido em seus contextos de uso, na construção social de seus sentidos.

Essa noção vem de uma crítica do filósofo à ideia da existência de uma linguagem privada fundamentada na aceitação de que o conhecimento alicerça-se nos dados sensíveis e não partilháveis e que a nossa compreensão das afirmações existenciais (dos sentimentos, das sensações), em geral, tem origem em suas próprias experiências imediatas (FAUSTINO apud NEVES, 2008, p. 13). Os significados dos termos da linguagem privada seriam assim as próprias experiências sensórias a que se referem (WILLIAMS, 1999, p. 15). Wittgenstein refuta essa tese ao compreender, a partir da noção de jogos de linguagem e de forma de vida, que a linguagem é social e pública, como enfatizamos anteriormente, e suscetível de transmissão, isto é, pode ser ensinada e aprendida.

Desse modo, uma linguagem conhecida por uma pessoa e somente por essa pessoa é impossível, do mesmo modo que é inviável uma linguagem em que os termos 
são fixados socialmente, mas os referentes da sensação-termo são conhecidos somente pelo indivíduo que se refere a eles (WILLIAMS, 1999). Desse modo, não podemos falar em uma referência privada, tudo que há são referências comuns. Aqui nos permitimos uma pequena digressão para avançar um pouco mais nessa discussão. Podemos tomar o exemplo do jogo de linguagem do "besouro na caixa" de Wittgenstein para tornar o argumento da impossibilidade de uma linguagem privada mais claro. O filósofo austríaco diz que:

Quando digo de mim mesmo que sei o que significa a palavra "dor" apenas a partir de um caso específico, - não devo também dizer isto de outros? E como posso generalizar um caso de modo tão irresponsável? Ora, alguém me diz, a seu respeito, saber apenas a partir de seu próprio caso o que sejam dores! - Suponhamos que cada um tivesse uma caixa e que dentro dela houvesse algo que chamamos de "besouro". Ninguém pode olhar dentro da caixa do outro; e cada um diz que sabe o que é um besouro apenas por olhar o seu besouro. - Poderia ser que cada um tivesse algo diferente em sua caixa. Sim, poderíamos imaginar que uma tal coisa se modificasse continuamente. Mas, e se a palavra "besouro" tivesse um uso para estas pessoas? - Neste caso, não seria a designação de uma coisa. A coisa na caixa não pertence, de nenhum modo, ao jogo de linguagem nem mesmo como um algo: pois a caixa poderia também estar vazia. - Não por meio desta coisa na caixa, podese 'abreviar'; seja o que for, é suprimido.

Isto significa: quando se constrói a gramática da expressão da sensação segundo o modelo de 'objeto e designação', então o objeto cai fora de consideração, como irrelevante. (WITTGENSTEIN,1999, §293, grifo do autor)

Com esse exemplo, Wittgenstein quer mostrar que sensações como a dor são comumente entendidas em seu contexto reativo, isto é, junto com fatores comportamentais, psicológicos e circunstanciais que acompanham a noção de "dor" (gritar, fazer uma careta, chorar), sem os quais a dor (objeto) torna-se algo totalmente desconectado dos modos comuns que temos para falar dela e experimentá-la (WILLIAMS, 1999, p. 29). Isto é, se cada um tem o "seu besouro" e somente o indivíduo pode saber na primazia de sua experiência o que é o seu besouro, sendo esses fatores reativos meramente acidentais rodeando a dor em sua essência, a referência perde o seu contexto, se separa das circunstâncias das quais fazem parte. O objeto besouro (a dor) nesse caso torna-se completamente dissociada do uso da palavra "besouro" (“dor”), uma vez que o besouro (a dor) pode ser qualquer coisa ou nada, sem afetar o uso da palavra (ibidem, p. 32).

"Dor", como "besouro", tem um uso público e social, enquanto a dor em si, como o besouro, é conhecida somente pelo indivíduo sozinho. Como o argumento do parágrafo 293 nos mostra, é justamente essa tentativa de preservar a integridade da dor em si que paradoxalmente acaba por eliminar a 
dor $^{70}$. O objeto dor torna-se assim tão irrelevante quanto o besouro se torna: não faz diferença se a dor é uma entidade durável, que muda constantemente ou se não é nada. Contudo, se nada tem função tanto quanto algo, então o objeto da designação, i.e., aquilo que deveria fazer uma diferença (de fato toda a diferença) para a designação é eliminado. Ao transformar a sensação em um objeto tão misterioso, ele é removido da vida humana. (WILLIAMS, 1999 , p. 32, tradução nossa ${ }^{71}$ )

Desse modo, não faz sentido afirmar que podemos conhecer tampouco se referir (falar de) algo em sua essência, desconectado de um contexto, de uma forma de vida e do entorno social. Dessa reflexão, proposta no parágrafo 293 de Wittgenstein, depreende-se, assim, que um único caso isolado não serve para significar uma palavra, uma vez que o significado se dá nos diferentes usos. O uso, por sua vez, irá configurar o significado porque está atrelado a contextos em que determinada palavra terá determinado sentido, isto é, nos jogos de linguagem. Desse modo, compreender e referir-se à dor ou qualquer outra sensação é um empreendimento público $e$ comunitário, porque estes são os elementos que conformam a natureza da linguagem. Esta tem existência porque é social, partilhável e transmissível, “embora, segundo Wittgenstein, a pessoa que experimenta a sensação não possa estar enganada a respeito dessa mesma sensação, tal só ocorre porque ela já aprendeu o significado da apropriada palavra indicadora da sensação, através dos liames de ensino” (PEARS, 1988, p. 163).

Posto isso, mesmo que imaginemos outra situação, uma mais simples como o ato de falar consigo mesmo "em pensamento", inclusive nessa circunstância, não podemos excluir o que há de social e externo na linguagem. Mesmo que falemos sozinhos, temos como interlocutor um outro que é um outro "eu", e a linguagem que usamos nessa situação é resultado de uma forma de entender o mundo que foi socialmente construída (e que mantém-se em transformação) antes mesmo da nossa existência. Desse modo, um discurso não pronunciado, interior, é nada mais que uma omissão, que uma não exteriorização do discurso, o que de todo modo não o caracteriza como parte de uma linguagem privada.

Referir-se à linguagem sem admitir a existência de um outro torna-se assim impossível. Os jogos de linguagem envolvem, desse modo, duas perspectivas distintas

\footnotetext{
${ }^{70}$ Com isso, Wittgenstein não quer dizer que a pessoa não sinta a dor, a dor a que Williams se refere aqui é o objeto significado no jogo de linguagem, o objeto designado.

71 "'Pain', like 'beetle', has a public, social use while the pain itself, like the beetle, is known to the individual subject alone. As the argument of PI $\$ 293$ shows, this very attempt to preserve the special integrity of the pain itself paradoxally results in eliminating the pain. The object pain drops out as irrelevant just as the beetle does: It makes no difference if the pain is an enduring entity, constantly changing, or nothing at all. But if a nothing serves as well as something, then the object of designation, i.e., that which is supposed to make a difference (indeed all the difference) to the designation, is eliminated. By transforming sensations into such mysterious objects, they are removed from human life."
} 
que se complementam, isto é, de um sujeito emissor e de um sujeito interlocutor, dependendo da partilha da forma de vida entre eles, pois trata-se de uma ação intencional que somente na medida em que se dirige ao outro e o envolve, o jogo de linguagem pode ter inicio (NEVES, 2008, p. 43-44). O falar de uma linguagem está, assim, atrelado a uma intersubjetividade, que constitui a própria subjetividade. Para Bakhtin, a alteridade define o ser humano, na medida em que o outro é fundamental para sua concepção, “é impossível pensar no homem fora das relações que o ligam ao outro" (BAKHTIN apud BARROS, 1996, p. 26).

Podemos discutir essa compreensão de intersubjetividade a partir de Peirce. O filósofo americano nos mostra que a subjetividade do homem pode ser entendida como semiose e a realidade da mente como um signo: "A palavra ou o signo que o homem usa é o próprio homem. O fato de que todo pensamento é um signo, tomado em conjunção com o fato de que a vida é uma sucessão de pensamento, prova que o homem é um signo" (CP 5.314, tradução nossa ${ }^{72}$ ). Como vimos, o signo é "aquilo que representa algo para alguém sob certa circunstância ou capacidade. Dirige-se a alguém, isto é, cria na mente da pessoa, um signo equivalente, ou talvez, um signo mais desenvolvido" (CP 2.228, tradução nossa ${ }^{73}$ ). Nesse sentido, o homem, enquanto signo, não está fechado em si mesmo, "o sujeito humano se caracteriza por sua abertura, por sua capacidade de relação, por sua capacidade de estar em comunicação com outros, em relação com o mundo" (BARRENA, 2001, tradução nossa ${ }^{74}$ ), isto é, está aberto a incorporar mais e mais signos em suas relações com os outros e com o mundo, preenchendo e "alongando" a cadeia de signos (semiose) que caracteriza sua subjetividade. Lotman, de modo semelhante, propõe que "a inteligência do homem se modifica à medida que o conhecimento se acrescenta, a pessoa é resultado da interação com o meio semiótico", para ele, a inteligência humana, a cognição, é um fato cultural (ARÁN, 2001, p. 50, tradução nossa ${ }^{75}$ ).

Essa abertura da subjetividade é o que permite que o homem se relacione e é inerente ao seu modo de ser: o "eu" é comunicável, "externo" (a mente é um fenômeno

\footnotetext{
72 " $[\ldots]$ the word or sign which man uses is the man himself. For, as the fact that every thought is a sign, taken in conjunction with the fact that life is a train of thought, proves that man is a sign"

73 " [...] is something which stands to somebody for something in some respect or capacity. It addresses somebody, that is, creates in the mind of that person an equivalent sign, or perhaps a more developed sign."

74 “"...] el sujeto humano se caracteriza precisamente por su apertura, por su capacidad de relación, por su capacidad de estar en comunicación con otros, en relación con el mundo.”

75 "la inteligencia del hombre se modifica a medida que el conocimiento se acrecienta, la persona es resultado de la interacción con el medio semiótico.”
} 
externo), de modo que Peirce chega a afirmar que é mais verdadeiro que os pensamentos de um escritor vivo estejam em seus livros impressos que em seu cérebro (CP 7.634). O sujeito pode ser entendido assim como "um conjunto de possíveis relações que vão se atualizando com o tempo", dada sua incompletude. Por não estar fechado em si mesmo, o homem pode comunicar seus pensamentos e sentimentos aos outros, "de maneira que esteja quase literalmente no outro" (BARRENA, 2001, tradução nossa ${ }^{76}$ ):

[...] “Toda comunicação de mente a mente se dá na continuidade do ser" (CP 7.572). [Peirce] está falando aqui de toda comunicação triádica, isto é, que envolva a transmissão de uma mensagem e sua compreensão, sua transformação em crenças e hábitos etc., e não simplesmente uma transmissão de sinais (comunicação diádica). Sendo assim, a "continuidade do ser" é requisito para toda comunicação mediada por signos, inclusive a comunicação mediada por meios tecnológicos, porque a mente de cada indivíduo está nessa continuidade onde também estão as mentes de todos os indivíduos na mesma comunidade - é nesse sentido que a relação entre consciências é possível. (SILVA, 2013, p. 153)

$\mathrm{O}$ falar de uma linguagem, a transmissão de mensagens e o que permite que essa mensagem seja compreendida de determinada maneira está assim atrelado a uma intersubjetividade, isto é, à relação do sujeito com os outros sujeitos no processo de apreensão do mundo. A intersubjetividade que está implícita na interpretação da forma de vida como cultura, da qual falávamos anteriormente, nos leva a pensar que uma linguagem como o meme não pode ser compreendida fora do seu caráter comunitário:

Partilhamos uma forma de vida. Eis o significado das linhas de um novo signo do pertencimento cultural a estabelecer nossas práticas e modos de relação. A forma de vida é o sinal da existência de uma prática e de um significado que não são meus, porém nossos e nossos de várias maneiras o que sugere uma intensidade do partilhar a viabilizar a coesão da comunidade. Assim, por exemplo, o filósofo [Wittgenstein] nos alerta que a palavra "dor" adquire seu sentido nos entendimentos entre as pessoas mais do que num aprendizado contemplativo da experiência interior e isto porque a linguagem com suas regras a determinar os diferentes modos de ser e estar no mundo é o elemento primeiro e primordial de uma comunidade. (VALLE, 2012, p. 171)

O falar de uma linguagem é, assim, um acontecimento organizado dentro de uma comunidade cuja coesão entre os membros permite que emerja modos de compreensão de um objeto. O que destacamos aqui no que se refere ao conceito de forma de vida é principalmente a ideia de partilha que o acompanha: compreender o outro e a realidade implica compartilhar uma forma da vida. Essa noção lança luz a um aspecto contextual dos jogos de linguagem, no sentido de que a referência a uma forma de vida nos permite

\footnotetext{
76 "[...]un conjunto de posibles relaciones que se van actualizando en el tiempo."

"[...]de manera que esté casi literalmente en el otro"
} 
“enfocar a relação entre a linguagem e as situações nas quais fazemos os nossos proferimentos". Para Velloso, “ao usar a expressão 'formas de vida', Wittgenstein estaria incorporando à linguagem justamente essas situações interpessoais" (VELLOSO, 2003, p. 182).

Existe, portanto, um conjunto de práticas, convenções e conhecimentos, que podemos entender aqui como a forma de vida, nos quais está imersa a linguagem que tem o seu papel no estabelecimento de critérios de sentido de cada jogo de linguagem (DALL'AGNOL, 2009, p. 291), de cada proferimento, isto é, de cada ocorrência com repetição paródica que estamos entendendo como meme:

[...] a forma de vida da comunidade - porque não se faz com o indivíduo, mas sim no grupo - é o que possibilita usarmos a linguagem para nos referirmos à realidade e compreendê-la; o fato de que os fenômenos vão se caracterizar em suas manifestações possíveis - em contextos reativos, em formas de vida - significa que a linguagem se alimenta e tem sentido na forma de vida. (SILVA, 2013, p. 140)

Assim, o sentido comum, seja de uma proposição, seja de um meme, vai ocorrer "em um contexto de práticas e crenças mutuamente aceitas" e só pode ser compreendido "olhando para as circunstâncias concretas em que ocorre" (WILLIAMS, 1999, p. 28 apud SILVA, 2013, p. 141). Em outras palavras, podemos afirmar que a compreensão de uma ocorrência memética decorre da capacidade do interlocutor de relacionar um meme com outros objetos, isto é, fatos, imagens, eventos, sua vida particular, um clichê, um estereótipo, entre outros elementos que fazem parte da circunstância de produção e recepção de um meme inseridos no contexto de uma "cultura de memes da internet". Entender a construção de sentido em uma linguagem é, portanto, estar ciente dos jogos que os falantes dessa linguagem realizam, em determinadas conjunturas, a partir de certa regularidade (generalidade, regras, hábitos) que revelam uma relação (mediação) do pensamento de uma coletividade com o mundo, pois falar uma linguagem nada mais é que falar do mundo.

\subsection{Semiosfera, semiose e compreensão}

Se a compreensão de forma de vida sugere que o falar da linguagem envolve de alguma maneira uma comunidade que partilha certas atividades, podemos imaginar que essa noção se aproxima do que Lotman propõe como memória na semiosfera, no sentido de que Lotman também está tratando de uma partilha: uma partilha de saberes, necessária para que a comunicação aconteça, no caso de nossa análise, para que algo 
seja comunicado por um meme. Isto nos permite depreender o que engendra a compreensão das ocorrências meméticas de determinada maneira e não de outra e o que define quem as compreenderá de tal ou tal forma ou simplesmente não entenderá.

No capítulo anterior, propusemos que o funcionamento da internet, entendida como um meio de comunicação, poderia ser comparado ao de uma semiosfera, um espaço semiótico no qual se inserem textos, linguagens e os indivíduos com seus mundos semióticos, como exposto na metáfora que compara a semiosfera a um ambiente de um museu. Desse modo, a rede de computadores não configurar-se-ia apenas como um suporte feito de cabos e telas, mas sim como um espaço de cultura, criado ao estendermos ao meio a nossa faculdade de comunicação, caracterizada por uma relação de consciências. É nesse espaço (e transformando constantemente esse espaço) que se compreende a existência de uma comunidade linguística (interpretativa) do meme.

Por membro de uma comunidade linguística, Jakobson vai entender interlocutores que "podem ser definidos como usuários efetivos de um único e mesmo código linguístico, que compreende os mesmos legi-signos", para ele, o compartilhamento desse código comum é o que viabiliza a comunicação, sendo o fundamento e a possibilidade efetiva da troca de mensagens (JAKOBSON apud RUSSI, 2013, p. 52). Entender um meme, portanto, depende do conhecimento de suas regras e dinâmicas para produzir significados, isto é, certa "intimidade linguística", decorrente da prática do meme, do uso, da participação nos seus jogos de linguagem. No caso do meme, a participação não significa uma produção efetiva de uma montagem, de um vídeo, de uma fotografia. O que queremos dizer com isso? Simplesmente que pessoas que somente "leem" os memes sem nunca ter de fato produzido uma imagem sequer, se os compreendem, fazendo em sua leitura as relações necessárias para a formação de um sentido pretendido, também se configuram como um interlocutor integrante dessa comunidade linguística, pois, como nos mostra Jakobson, aquele que ouve também é um falante em potencial (MACHADO, 2007, p. 63). Nesse sentido, compreender um texto em determinada linguagem demanda o conhecimento de certas regras e a isso acrescentamos também o contexto de emissão e recepção, a situação comunicativa que configura os modos como os textos articulados na linguagem do meme serão entendidos.

A emissão ou proferimento de um meme na dinâmica dos jogos de linguagem pode ser tomada em uma perspectiva da semiótica da cultura como uma reinterpretação 
ou "tradução criadora". Como vimos, na metáfora espacial de Lotman, a cultura possui uma zona fronteiriça que "separa" seu espaço interno do de fora, "o alheio", "o reino dos elementos caóticos desordenados" (LOTMAN apud ARÁN, 2001, p. 57), que na realidade pode ser entendido como “um espaço 'outro' onde se codifica de modo diferente o mundo e os textos" (ARÁN, 2001, p. 57). A fronteira se configura, assim, como um espaço que tanto une quanto separa. A união reside no fato de que é na fronteira que se tornam possíveis as trocas informacionais, a conexão entre diferentes esferas culturais, o contato com "mundo externo". Ao mesmo tempo, essa divisa promove uma separação, ao delimitar a especificidade de uma cultura. Há de se observar, contudo, que essa demarcação não se estabelece rigidamente, visto que a fronteira é um espaço penetrável:

É necessário sublinhar que o confim que separa o mundo fechado da semiose da realidade extra-semiótica é penetrável. Este se encontra constantemente atravessado por incursões de elementos provenientes de esferas extrasemióticas, que irrompem e levam consigo a dinâmica; eles transformam este espaço ainda que ao mesmo tempo sejam transformados segundo suas leis (LOTMAN, 1999, p. 160 apud RAMOS et al., 2007, p. 39, tradução nossa ${ }^{77}$ )

Esse "fechamento" de que fala Lotman, entendemos aqui não como um bloqueio à comunicação, pois a semiose é justamente um processo de abertura e de crescimento. Trata-se apenas de reconhecer que a fronteira delimita os traços de um sistema que estipulam sua especificidade sígnica (RAMOS et al., 2007, p. 39-40). Compreendemos, assim, que a tradução/conversão semiótica de um elemento externo à cultura digital do meme pode ser entendida como uma tradução dessa informação em sua linguagem, processo que pode ser encarado como uma semiose - que na perspectiva da semiótica da cultura consiste na " transformação da informação percebida em informação codificada, isto é, em texto" (MACHADO, 2013, p. 64). Desse modo, as ocorrências meméticas se darão nesse processo de incorporação de um fragmento informacional e a sua transformação no interior da semiosfera, no "choque" desse texto de origem com outros textos:

A recepção de textos provenientes de outras culturas, a ativação de zonas
periféricas de uma cultura ou os fenômenos de conversão ou interferências de
um texto com outro se realizam no processo dinâmico da semiose cultural. O
texto inicial se converte em um texto alheio formando assim uma nova
mensagem. A complexidade e a multiplicidade dos componentes
participantes na interação textual conduzem a certa "imprevisibilidade" na

77 “....es necesario subrayar que el confín que separa el mundo cerrado de la semiosis de la realidad extrasemiótica es penetrable. Este se alla contantemente atravesado por incursiones de elementos provenientes de esferas extrasemioticas, que irrumpen y llevan consigo la dinámica; ellos transforman este espacio, aunque al mismo tiempo sean tranformados según sus leyes". 
transformação a que se submeteu o texto de base. (ARÁN, 2001, p. 54, tradução nossa ${ }^{78}$ )

Esse processo seria a reinterpretação ou tradução criadora. Nele o contato de um texto com uma consciência individual ou coletiva produz no texto mãe "um estado de excitação, uma perda de equilíbrio semiótico dos subtextos que o constituem e podem começar a apresentar-se como estranhos uns aos outros e inclusive a gerar novas mensagens a partir de outras leis que lhes eram alheias até então" (ibidem, p. 54-55, tradução nossa ${ }^{79}$ ). A reinterpretação ou tradução criadora pode ser compreendida assim como a maneira que determinada linguagem configura o nosso acesso ao real, o nosso entendimento do mundo. Uma vez que tomamos o texto base como "um outro" a ser interpretado, podemos entendê-lo como um objeto que, pela mediação da linguagem, determina um interpretante. Acreditamos, desse modo, poder considerar uma ocorrência memética como semiose - a ação da linguagem do meme, em sua maneira própria de expressão - na conformação inteligível do mundo.

Entendemos a semiose, que tomamos aqui como referência para compreender a linguagem do meme em ação, como um processo de significação: como algo (um evento, um ato, um animal, uma pessoa, entre outros que servem de objeto para um meme) se dá a conhecer, ganhando sentido em uma comunidade.

Essa ação, o significar, é uma atividade que prescinde dos três correlatos que abordamos anteriormente:

O signo - algo que representa algo para alguém em algum aspecto ou caráter”, seu fundamento (CP:2.228, 1897), o objeto - o que é representado pelo signo - e o interpretante - outro signo, que é causado pelo primeiro signo na mente do que o interpreta. A semiose é a mediação significativa deste (o signo interpretante) entre aqueles (o signo e o objeto). (GORLÉE, 1992, grifo e tradução ${ }^{80}$ nossos)

A ação do signo, consiste assim em funcionar como mediador entre o objeto e o efeito que se produz numa mente (atual ou potencial) que interpreta, compreende, dá

\footnotetext{
78 "La recepción de textos provenientes de otras culturas, la activación de zonas periféricas de una cultura o los fenómenos de conversión o de interferencias de un texto con otro hacen al proceso dinámico de la semiosis cultural. El texto inicial se convierte en un texto ajeno formando así un nuevo mensaje. La complejidad y la multiplicidad de los componentes participantes en la interacción textual conducen a cierta "imprevisibilidad" en la transformación a que es sometido el texto de base."

79 “"...] un estado de excitación, una pérdida del equilibrio semiótico de los subtextos que lo constituyen y que pueden empezar a presentarse como extraños los unos a los otros e incluso a generar nuevos mensajes a partir de otras leyes que le han sido ajenas hasta entonces."

80 “ [...] el signo -«algo que representa algo para alguien en algún aspecto o carácter», su fundamento (CP: $2.228,1897$ ), el objeto -lo que es representado por el signo- y el interpretante -otro signo, que es causado por el primer signo en la mente del que lo interpreta-. La semiosis es la mediación significativa de éste (el signo interpretante) entre aquellos (el signo y el objeto)."
} 
sentido. Para ilustrar essa conexão entre os três correlatos, Deely nos apresenta o exemplo do termômetro que Peirce utiliza para ilustrar a relação:

\begin{abstract}
Peirce dá o exemplo do movimento do mercúrio num termômetro, que é causado "de modo puramente bruto e diádico" pelo aumento de calor no ambiente, mas que ao ser percebido por alguém que esteja familiarizado com termômetros produz também a ideia de aumento de temperatura ambiente. $[\ldots]$

O objeto do termômetro como signo é a temperatura relativa do ambiente. $\mathrm{O}$ objeto da ideia do termômetro como signo não é diferente. Entretanto, o termômetro antes de ser "lido" está envolvido apenas em interações dinâmicas. Quando da leitura, um terceiro fator é introduzido, a interpretação. (DEELY, 1990, p. 43)
\end{abstract}

Desse modo, o termômetro como signo não representa apenas si mesmo, mas algo além. Ele não é apenas existência (coisa, primeiridade), não apenas se manifesta para alguém (objeto, secundidade), ele "se manifesta para alguém como representação de algo a mais" (signo, terceiridade). O interpretante é assim o fundamento sobre o qual o signo pode ser visto como uma relação com algo mais: o significado (ibidem, p. 44).

A ação do signo é, portanto, sua capacidade de, ao significar, gerar outros signos (signos interpretantes). Quando Peirce percebe que o desenvolvimento da semiótica como um campo distinto de conhecimento demandava a visão da significação (semiose) como processo, o que ele propunha era que o entendimento do signo "não se tratava apenas de uma questão sobre o Ser próprio do signo ontologicamente considerado", havia também outra questão acerca dele: "a questão do Tornar-se que esse tipo peculiar de Ser [o signo] possibilita e pelo qual se sustenta"- em outras palavras, como mostra Deely, essa era a constatação de que os signos não apenas existem, mas também crescem (ibidem, p. 42). Esse crescimento consiste na capacidade de se "expandir" ao originar outros signos (interpretantes). Nesse sentido, faz parte da natureza do signo sua capacidade de gerar interpretantes, em uma cadeia contínua: "qualquer interrupção no processo degenera o caráter significante perfeito do signo, que é o de gerar um interpretante que gerará outro e assim indefinidamente" (SANTAELLA, 2008, p. 18). Podemos dizer, por conseguinte, que a semiose consiste na adição de novos elementos de informação a um objeto a ser conhecido (GORLÉE, 1992).

Cada ocorrência memética pode ser entendida, assim, como esse processo de (res)significar um objeto, isto é, o encadeamento de interpretações de uma informação dentro da cultura dos memes (tradução criadora). Lançando luz ao devir dos memes na tríade peirceana, podemos vislumbrar a informação como objeto, o meme como signo 
(linguagem) e cada manifestação desse meme (réplica) como um interpretante. Em nosso entendimento, se o meme é uma linguagem, isto é, o emprego de um signo, ele faz a mediação entre uma informação que nos chega pela mídia ou algo que está em nosso cotidiano que achamos digno de ser partilhado e as várias interpretações - os sentidos - que essa informação inicial pode ter. Recorremos aqui a três categorias de interpretante para esmiuçar um pouco mais a inferência que buscamos apresentar na compreensão da ação tradutória do meme na semiosfera, a semiose.

Peirce distinguia três interpretantes na semiose de um mesmo signo: o interpretante imediato, o interpretante dinâmico e o interpretante final - seriam três momentos lógicos desse correlato. O primeiro deles, o interpretante imediato, está relacionado com a primeira categoria fenomenológica que vimos anteriormente (primeiridade). Nesse sentido, ele existe como potencialidade, como uma possibilidade para significar inscrita em todo signo, é o "Interpretante representado ou significado no Signo" (CP 8.134, tradução nossa $\left.{ }^{81}\right)$.

Parafraseando Ransdell (1986b:681-682) se pode dizer que o primeiro interpretante é um mero indício da interpretabilidade do signo. Demonstra o interpretante imediato o poder gerativo do signo, revelando - de maneira ainda bastante vaga e indefinida - o rosário dos possíveis interpretantes que o mencionado signo, em determinadas condições, pode dar de si [...] (GORLÉE, 1992, tradução nossa ${ }^{82}$ )

O interpretante imediato consiste, assim, naquilo que um signo está apto a produzir numa mente interpretadora, ele é apenas uma possibilidade de sentido, ele é "tudo que está explícito no Signo em si mesmo, descartando seu contexto e circunstâncias de emissão" (CP 5.474, tradução nossa ${ }^{83}$ ). Por conseguinte, a mediação de um meme (signo) em um processo interpretativo de uma informação, evento, pessoa, etc. (objeto) tem como possibilidade infinitos sentidos em potencial. Podemos dizer que a relação sígnica meme-informação-usuário faz com que o objeto, uma imagem, por exemplo, possa significar "qualquer coisa". Quando essa possibilidade torna-se um fato concreto, isto é, quando um sentido é atualizado, já passamos para outro momento lógico do interpretante: o interpretante dinâmico, correspondendo à categoria fenomenológica da secundidade. Em linhas gerais, o interpretante dinâmico

\footnotetext{
81 “[...] the Interpretant represented or signified in the Sign".

82، Parafraseando a Ransdell (1986b:681-682) se puede decir que el primer interpretante es un mero indicio de la interpretabilidad del signo. Demuestra el interpretante inmediato el poder generativo del signo, revelando de manera aún bastante vaga e indefinida - el rosario de los posibles interpretantes que el mencionado signo, en determinadas condiciones, pudiera dar de sí [...]"

83 "[...] it is all that is explicit in the sign itself apart from its context and circumstances of utterance."
} 
É o efeito real produzido sobre um dado intérprete, numa dada ocasião e num dado estágio de sua consideração sobre o signo. Pode-se dizer também que o interpretante dinâmico é uma "determinação de um campo de representação exterior ao Signo (sendo tal campo a consciência de um intérprete), determinação essa que é afetada pelo Signo” (MS 339, p. 504).

Corresponde, enfim, ao que se pode chamar de significado do signo in concreto, isto é, o fato empírico de apreensão do signo, uma realização particular do significado, ou aquilo que comumente poderia ser referido como sendo o significado psicológico do signo, sendo, portanto, o único interpretante que funciona diretamente num processo comunicativo. Em termos genéricos se pode concluir, como o faz Ransdell (1983, p. 42), que o dinâmico é simplesmente "o interpretante do signo que realmente ocorre como uma ligação distinta numa cadeia semiótica, dando prosseguimento ao signo que semioticamente o determina." (SANTAELLA, 2008, p. 73)

O interpretante dinâmico é assim um ato particular de interpretação, um fato empírico, que na elucidação de nosso objeto podemos entender sua manifestação como uma réplica de um meme que configura o entendimento, a interpretação, a leitura que um usuário faz de algo (objeto) pela mediação da linguagem. Uma série de réplicas (interpretantes dinâmicos) nos permite assim conceber coletivamente, nos modos da cultura dos memes, algo sobre o mundo.

Para ilustrar essa dinâmica, tomemos como objeto o evento dos resultados das pesquisas de intenção de voto para o primeiro turno das eleições presidenciais em 2014: o Ibobe, Instituto Brasileiro de Opinião Pública e Estatística, indicou que o candidato Aécio Neves detinha quase $24 \%$ das intenções de votos no dia 4 de outubro de 2014 e, no dia seguinte, o dia da votação, o candidato estava com quase $35 \%$, segundo o instituto $^{84}$. Essa discrepância nos resultados das pesquisas passa a ser conhecida, interpretada, criticada, por uma comunidade, na manifestação de uma série de interpretantes dinâmicos que vem a conformar o meme Margem de Erro do Ibope (Figuras 7 a 10).

\footnotetext{
${ }^{84}$ Fonte: <http://youpix.virgula.uol.com.br/memepedia/os-melhores-ou-piores-memes-sobre-possibilidades-davida-segundo-margem-de-erros-ibope/> Acesso em 19/12/2014
} 
Figura 7 - Réplica do meme Margem de Erro do Ibope.

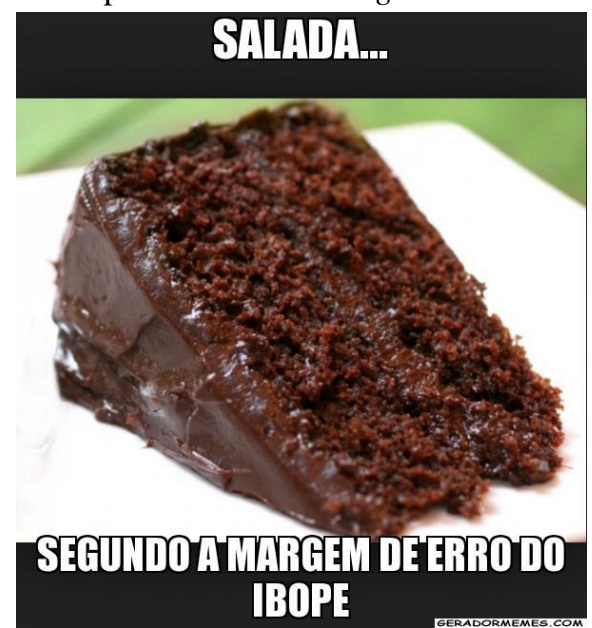

Fonte: geradormemes.com ${ }^{85}$

Figura 8 - Réplica do meme Margem de Erro do Ibope.

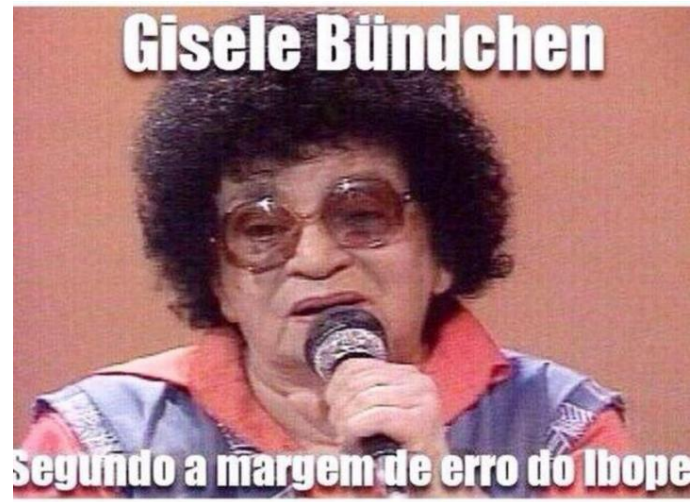

Fonte: entretenimento.r7.com ${ }^{86}$

Figura 9 - Réplica do meme Margem de Erro do Ibope.

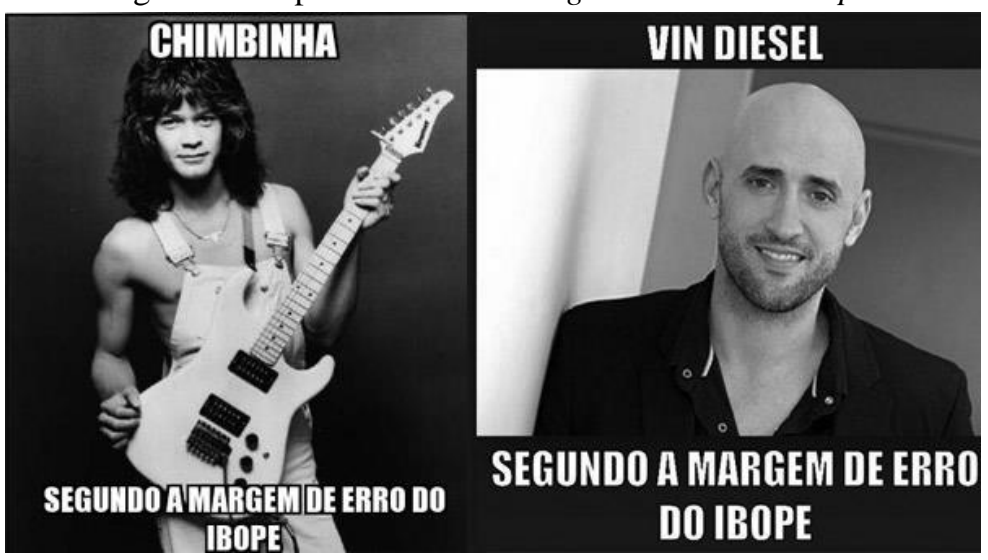

Fonte: youpix.com.br ${ }^{87}$

\footnotetext{
${ }^{85}<$ http://geradormemes.com/meme/eh8p1p> Acesso em 19/12/2014

${ }^{86}<$ http://entretenimento.r7.com/pop/fotos/margem-de-erro-do-ibope-vira-piada-nas-redes-sociais-veja-asmelhores-memes-14102014\#!/foto/4> Acesso em 19/12/2014

87 < http://youpix.virgula.uol.com.br/memepedia/os-melhores-ou-piores-memes-sobre-possibilidades-davida-segundo-margem-de-erros-ibope/> Acesso em 19/12/2014
} 


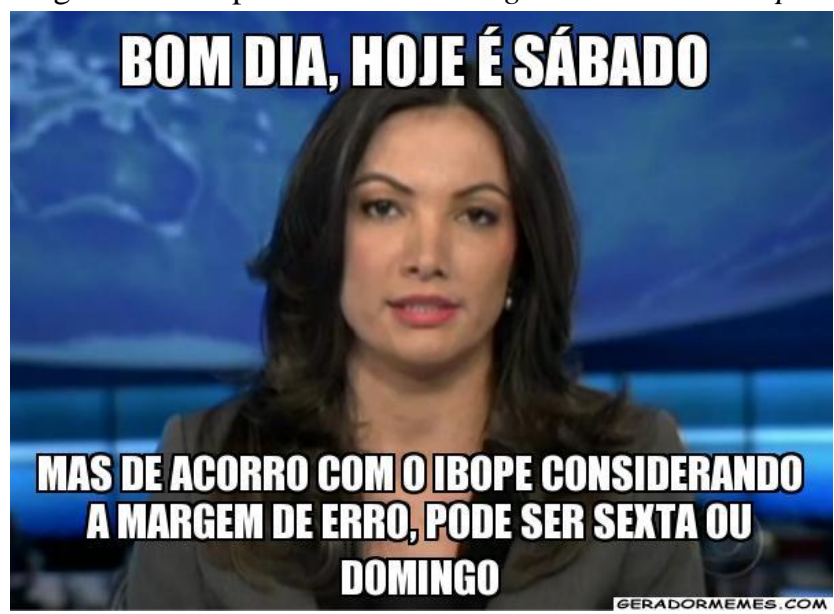

Fonte: geradormemes.com ${ }^{88}$

Podemos também dizer que é por um feixe de interpretantes dinâmicos, que a gata Tadar Sauce (objeto) passa a ser concebida como Grumpy Cat ${ }^{89}$ (Gato Rabugento) (signo), ganhando traços de personalidade que se reforçam a cada novo interpretante (Figuras 11 a 14). Desse modo, em uma interpretação coletiva uma "gata anônima" passa a figurar como um personagem mundialmente conhecido, passa a ser concebida de outra maneira pelo recorte dessas interpretações.

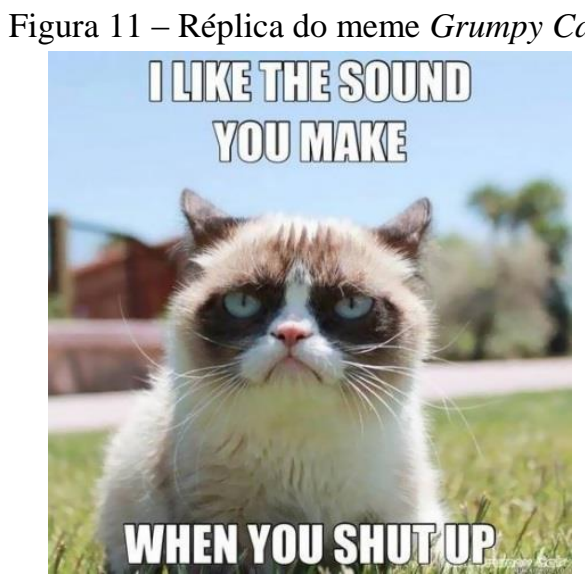

Fonte: youpix.com.br ${ }^{90}$

\footnotetext{
${ }^{88}<$ http://geradormemes.com/meme/7ye0or> Acesso em 19/12/2014

${ }^{89}$ Grumpy Cat foi o nome dado "pela internet" à gata Tadar Sauce, que tem um semblante que aparenta mau humor, devido a um nanismo. O animal ficou conhecido na web depois de ter algumas fotografias postadas no forum Reddit, em setembro de 2012. A fama se espalhou de tal forma que a gata participou de diversas campanhas de marcas e filmes e também foi lançado um livro com fotolegendas reproduzindo as ideias do meme, traduzido para mais de 15 idiomas. Em menos de dois anos sua dona faturou mais de 256 bilhões de reais. Fonte: <http://youpix.virgula.uol.com.br/memepedia/grumpy-cat-gata-que-virou-meme-ja-faturou-maisde-256-milhoes-de-reais/\#more-154173> Acesso em 6/1/2014

$90<$ http://youpix.virgula.uol.com.br/top10/comemore-o-dia-mundial-do-gato-com-7-imagens-videos-e-gifsdos-donos-da-web/> Acesso em 19/12/2014
} 
Figura 12 - Réplica do meme Grumpy Cat

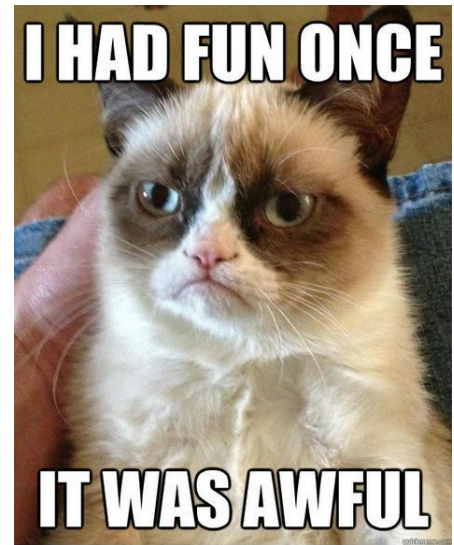

Fonte: knowyourmeme.com ${ }^{91}$

Figura 13 - Réplica do meme Grumpy Cat

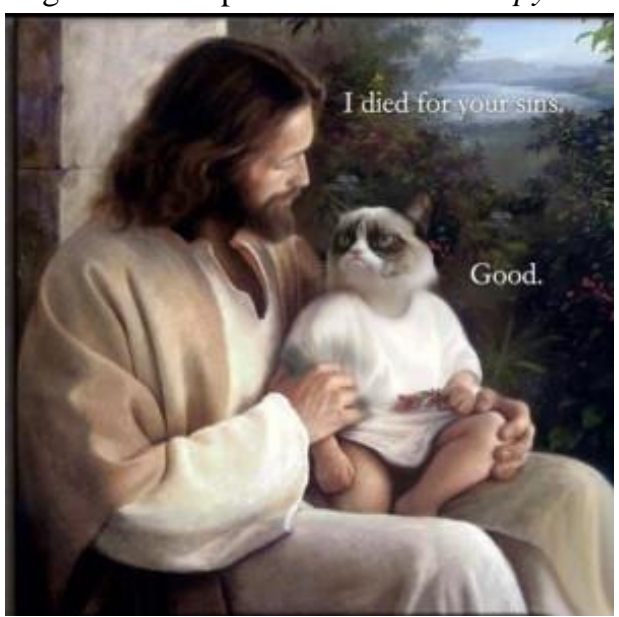

Fonte: zerobs.net ${ }^{92}$

Figura 14 - Réplica do meme Grumpy Cat

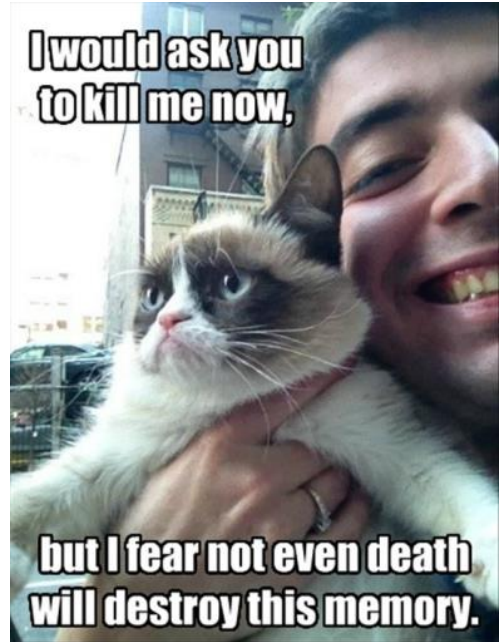

Fonte: pandawhale.com ${ }^{93}$

\footnotetext{
91 < http://knowyourmeme.com/memes/grumpy-cat> Acesso em 19/12/2014
}

$92<$ http://zerobs.net/grumpy-cat-meets-jesus> Acesso em 19/12/2014 
Posto isso, podemos afirmar que a linguagem do meme permite-nos conceber e comunicar ideias, interpretações, leituras daquilo que nos cerca, que se apresenta a nós enquanto secundidade, e que passa a ser compreendido de determinada maneira, pela sua mediação (os signos, o meme). A própria identidade de um meme enquanto um signo se dará, assim, nesse jogo de remissões a outros signos, i.e., uma cadeia de interpretantes, que permanece aberta a novas interpretações (PONZIO, 2011, p. 162).

Dando continuidade à exploração que fazíamos dos momentos lógicos do interpretante, é válido mencionar o terceiro e último deles: o interpretante final. $\mathrm{O}$ termo "final" não deve ser entendido aqui de modo literal, como se esse interpretante fosse um significado definitivo e, por assim dizer, estático, de um signo. Ele deve ser tomado como "o efeito significativo que o signo produziria em alguma mente, na qual as circunstâncias permitiriam surtir seu efeito completo" (PEIRCE apud GORLÉE, 1992, tradução nossa ${ }^{94}$ ). Em outras palavras, o interpretante final, considerado na ação do signo (semiose) - que se configura como um crescimento contínuo e tendência aparece como uma propensão para a qual rumam os interpretantes dinâmicos, sendo assim, um "limite ideal, aproximável, mas inatingível” (SANTAELLA, 2008, p. 74). Por conseguinte, se podemos determinar um significado para um meme (uma ocorrência memética), os interpretantes dinâmicos seriam atualizações do significado geral, realizações particulares desse significado. Eles "partem" de um interpretante imediato, inscrito na própria natureza do signo, "pura potencialidade e interpretabilidade não realizada", que estabelece uma relação dialógica com um interpretante final, "limite ideal para o qual, a partir desse potencial, as atualizações singulares, tendem a se dirigir" (ibidem, p. 76). O interpretante final não é, assim, um interpretante último, pois essa classificação alude momentos lógicos do interpretante, dessa forma, trata-se do “efeito semiótico pleno de um signo" (SAVAN apud SANTAELLA, 2008, p. 75). Dessa forma, o significado de um signo só pode ser conhecido por completo em algum futuro hipotético (GORLÉE, 1992).

As ocorrências meméticas se manifestam, assim, como uma semiose, uma sucessão de leituras sobre um evento, uma imagem, um vídeo, algo que desencadeie um

\footnotetext{
93 < http://pandawhale.com/post/10203/i-would-ask-you-to-kill-me-now-but-i-fear-not-even-death-willdestroy-this-memory> Acesso em 19/12/2014> Acesso em 19/12/2014

94 “"el efecto significativo que el signo produciría en alguna mente, en la cual las circunstancias permitirían surtir su efecto completo' (PW:110, 1909).”
} 
meme enquanto processo. Essas réplicas (que são também signos) são produzidas em uma situação comunicativa, um contexto cultural de apreensão, e dão continuidade a semiose, tornando-se objetos de um entendimento, uma vez que a compreensão dessas réplicas proferidas é também um ato semiósico: também envolve a ação do signo, a presença de um terceiro, isto é, a mente que os entende e interpreta.

As réplicas que compõem os memes, que também podem ser entendidas como textos em uma matriz lotmaniana da cultura, irão produzir sentido na semiosfera, que podemos tomar aqui como o contexto cultural da comunicação, a situação na qual a semiose se realiza, um espaço no qual destinador e destinatário encontram-se imersos e fora do qual não há comunicação (SANTAELLA; NÖTH, 2004, p. 142-143). A semiosfera nos permite entender, assim, a interação dos textos com os contextos (textos externos) e o mundo semiótico dos locutores da situação comunicativa e como essa dinâmica, em uma temporalidade dada, produz sentidos possíveis.

Por conseguinte, o meme enquanto uma forma de apreensão do mundo e também parte de um processo de comunicação não se configura simplesmente como uma transferência de dados, sendo na realidade transformado na decodificação: "o texto da comunicação se deforma no processo de decodificação efetuado por um destinatário que, longe de se caracterizar por uma percepção passiva, está dotado de competência comunicativa e interacional" (LOZANO,1995, tradução nossa ${ }^{95}$ ). Assim sendo, o receptor, por sua vez, não é um polo vazio na comunicação, porque esta não é algo dado, não é transmissão, é diálogo. Nesse sentido o meme se dá em um processo de interação entre interlocutores, demandando ser compreendido, escolhendo seu público à sua imagem e semelhança em uma semiosfera: aqueles membros da comunidade linguística interpretativa que o entenderão de determinada forma.

Para alguns, as montagens, os vídeos, as legendas das imagens que circulam na internet podem ser lidas como desordenadas, imperfeitas, "sem sentido", verdadeiros disparates, ao passo que, para outros, esses mesmos signos sustentam uma forma de comunicar legítima e coerente. Estes últimos compõem, assim, indivíduos-coletivos (a comunidade) que leem "de uma mesma maneira", ou pelo menos de modo bastante similar, os memes. Desse modo, podemos dizer que um texto "não deve ser avaliado somente na capacidade de se fazer compreendido por determinado destinatário, [...] mas também segundo o grau de incompreensão para os outros" (LOZANO, 1995, grifo e

\footnotetext{
95 “el texto de la comunicación se deforma en el proceso de decodificación efectuado por un destinatario que, lejos de caracterizarse por una percepción pasiva, está dotado de competencia comunicativo e interaccional."
} 
tradução ${ }^{96}$ nossos). O texto na cultura adquire, portanto, um caráter de intimidade ao definir "familiares e estranhos" a ele, "próximos e distantes", "os que entendem e os que não entendem" - intimidade essa que toma por base o princípio de que "quem deve entender, entenderá" (idem). É válido ressaltar que nos "entendedores" o meme pode surtir ainda um efeito de sua compreensão: o riso. A emissão de um meme, assim, parece também estar articulada a partir de uma intenção do destinador de comunicar o cômico, de ser engraçado, de divertir a si mesmo e ao seu destinatário ao jogar com a significação, fazendo do meme também uma concepção cômica do mundo. A consequência risível do entendimento, entretanto, não é o que faz de determinado processo sígnico um meme, sendo apenas um possível efeito resultante da situação comunicativa em que se inserem o meme e os interlocutores.

Nesse sentido, a incompreensão, a "falta de sentido", o "não achar graça" ou até mesmo um entendimento diferente da intenção do destinador (graus de incompreensão) são inerentes à comunicação: o ruído sempre é uma possibilidade comunicativa na medida em que "a não compreensão normal é um mecanismo de sentido tão importante quanto a compreensão" (LOZANO, 1999, tradução nossa ${ }^{97}$ ). O “não entender", portanto, faz parte da ação do signo, de modo que podemos dizer que esse nãoentendimento já é por si só um entendimento possível de algo, uma vez que a incompreensão também produz semiose na tentativa de dar sentido, de interpretar.

$\mathrm{O}$ ato de entender, desse modo, torna o meme "relativo a outros elementos na experiência do intérprete, colocando em movimento a cadeia de interpretantes da qual se alimenta a semiose como um processo" (DEELY, 1990, p. 45-46). A compreensão é, desse modo, um momento dialógico concreto, em que o intérprete combina e relaciona um signo (um texto, para Lotman) a outros signos (a contextos, i.e., outros textos), em um contato por trás do qual há o contato entre indivíduos e não de coisas:

\footnotetext{
O sentido global e unitário do signo não pode se separar dos contextos comunicativos concretos, da interação social, de seu nexo com determinados valores e perspectivas ideológicas. A interpretação de um signo [...] requer uma compreensão ativa. $\mathrm{O}$ sentido de um signo consiste em algo mais, no que diz respeito aos elementos que permitem seu reconhecimento. É feito desses aspectos semântico-ideológicos que são, em certo sentido, únicos, que têm algo de peculiar e de indissoluvelmente ligado ao contexto situacional da semiose. A compreensão do signo é uma compreensão ativa, pelo fato de que requer uma resposta, uma tomada de posição, nasce de uma relação dialógica e provoca uma relação dialógica: vive como resposta a um diálogo (PONZIO, 2011, p.187).
}

\footnotetext{
96 "Por eso mismo el texto no debe ser evaluado sólo sobre la base de la capacidad de hacerse comprender por un determinado destinatario [...] sino también según el grado de incomprensión para los otros."

97 “[...] la no comprensión normales un mecanismo de sentido tan importante como la comprensión.”
} 
Para Bakhtin, a compreensão é uma forma de diálogo, e parafraseando o autor, podemos dizer que ela está para um meme assim como uma réplica está para outra no diálogo (BAKHTIN, 1986, p. 132). É como se o texto nos colocasse questões ao ser interpretado e a nossa compreensão aparece como respostas a essas perguntas. Essas respostas estariam na nossa experiência e a compreensão se daria, portanto, não apenas pelo domínio das regras da linguagem, mas também graças a uma observação colateral, i.e., um conhecimento prévio sobre o assunto, outras experiências já tidas com determinado objeto, que nos conduz à compreensão do sentido do que está representado em um meme: "a pessoa que interpreta essa sentença (ou qualquer outro signo) deve ser determinada pelo seu objeto através da observação colateral totalmente independente da ação do signo" (PEIRCE apud RUSSI, 2013, p. 53). Nos memes, poderíamos entender essa observação colateral como outras formas de representação do objeto (informação) que se torna um meme, isto é, conhecer, em outros contextos, os textos que são parodiados para configurar um meme.

Nesse sentido, compreender um meme de determinada maneira, uma maneira próxima da que objetiva seu criador, significa orientar-se em relação ao meme, "encontrar o seu lugar adequado no contexto correspondente" (BAKHTIN, 1986, p. 132), isto é, localizá-lo em uma semiosfera, na qual destinador e destinatário partilham saberes mútuos (uma memória comum) e que também é determinada por uma temporalidade, que em um momento concreto de produção e recepção de memes confere um sentido e não outro, atualizando uma significação em uma esfera de possibilidades não-realizadas.

Graças à nossa temporalidade, temos uma coisa em um momento e outra coisa em outro momento, com ambas as coisas jogadas dentro da mesma sacola como parte de um vasto oceano em um constante movimento de autoorganização que se encontra permanentemente se tornando algo diferente do que é. (MERRELL, 2003, p. 174-175)

Nesse sentido, a temporalidade opera como um recorte possível, no qual o emissor do meme pode interpretar e buscar significar um objeto de determinada maneira e o leitor desse meme pode entendê-lo, estando ambos imersos na mesma semiosfera, no mesmo momento dialógico concreto. Desse modo, podemos inferir que nenhuma interpretação já está fixada ou dada, mas apenas sugerida, dependendo, assim, o entendimento do meme das relações que ele contrai no contexto cultural, no espaço semiosférico. O sentido refere-se, assim, à situação concreta na qual a semiose se realiza 
(PONZIO, 2011, p. 164), o sentido, isto é, o entendimento, está na semiosfera e no recorte da temporalidade.

É nesse contexto de emissão e recepção, no processo de tradução criadora da imagem de Cristo, por exemplo, que a linguagem e a cultura dos memes da internet nos permitem concebê-lo e aceitá-lo como alguém boçal e desbocado (Figura 15).

Figura 15 - Réplicas do meme Jesus Manero.

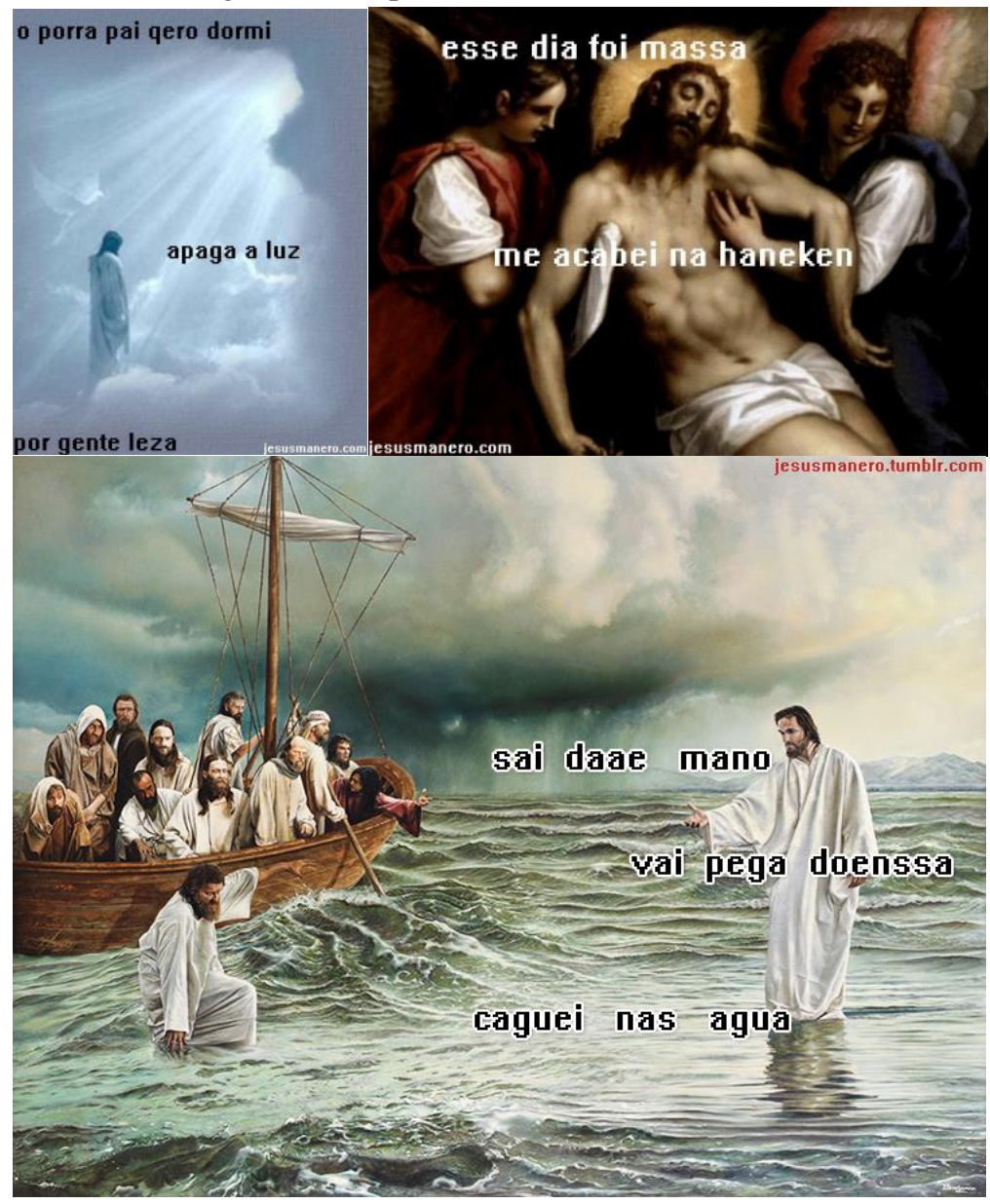

Fonte: jesusmanero.tumblr.com ${ }^{98}$.

Essas imagens tomadas em outra semiosfera, em outra temporalidade, em uma leitura diferente podem ser entendidas como heresia. Na semiosfera de uma cultura digital memética, contudo, são entendidas como "uma daquelas piadas da internet", ou melhor, um meme. É uma situação comunicativa, em um contexto cultural específico, que permite que o cômico apareça nessa relação textual (imagem e legenda), para além de uma falta de respeito (ainda que em outra situação isso possa ser entendido como desrespeitoso). E mesmo que o entendimento disso não resulte na percepção do cômico,

\footnotetext{
${ }^{98}$ Disponíveis em: <http://jesusmanero.tumblr.com/> Acesso em 29 de janeiro de 2014.
} 
a presença de certo tipo de repetição e paródia permite-nos tomar essas construções textuais como um meme.

É nessa mesma cultura, e articulada pelas mesmas regras (repetição e paródia), que Grace Van Cutsem, fotografada no casamento real do Príncipe William com Kate Middleton (Figura 16), pode atuar como sinônimo de incômodo. Em um dado momento, sua imagem passa a ser largamente usada (repetição) em montagens diversas (paródias) e esses usos, estabelecidos como um jogo de linguagem, permitem que a sua imagem, naquele momento fotografado, seja tomada como outra coisa que não a pessoa Grace, mas sim um conceito, a ideia de importuno, constituindo algo que entendemos como meme, o meme Royal Wedding Girl (Menina do Casamento Real) (Figuras 17 a 19).

Figura 16 - Príncipe William e Kate Middleton no Palácio de Buckingham.

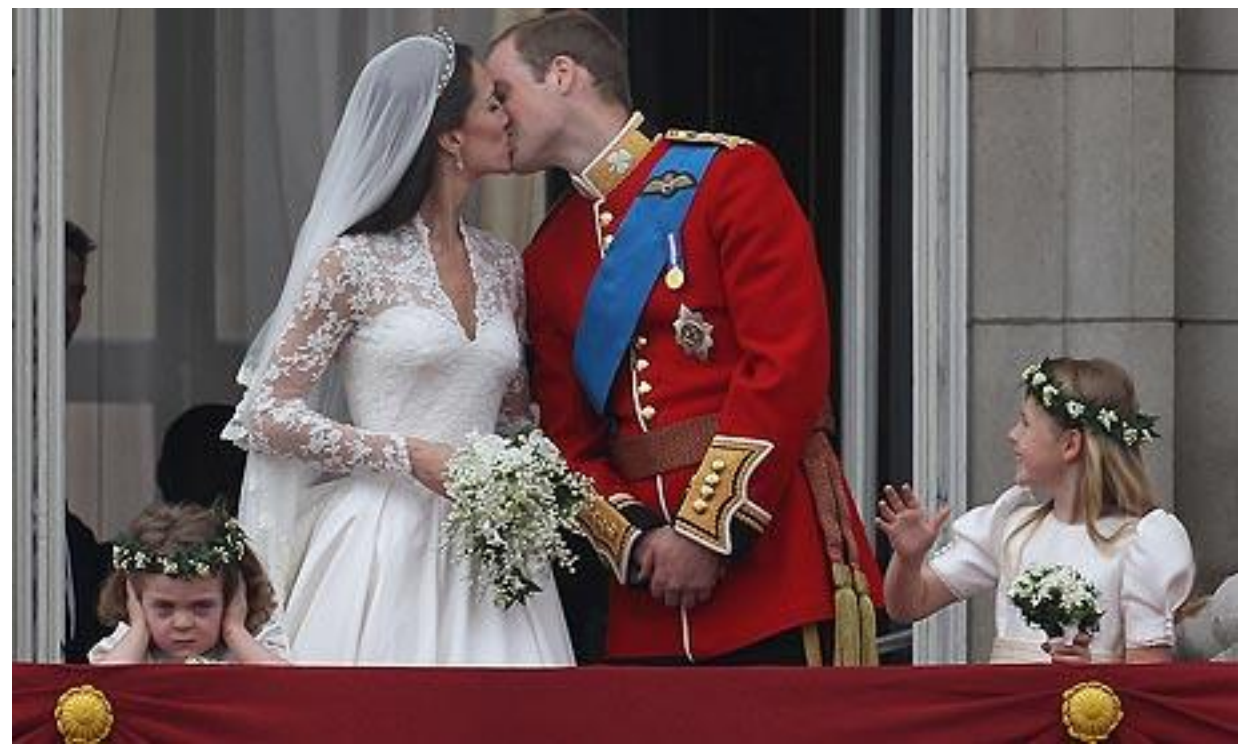

Fonte: www.theguardian.com ${ }^{99}$

99 Disponível em: <http://www.theguardian.com/media/2011/apr/29/power-surge-royal-wedding-ratings > Acesso em 28/1/2014. 
Figura 17 - Réplica do meme Royal Wedding Girl.

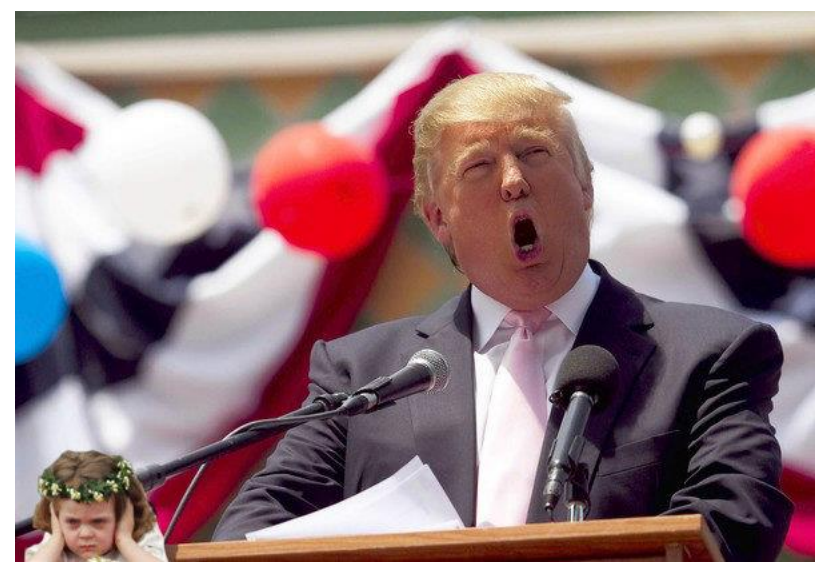

Fonte: knowyourmeme.com ${ }^{100}$

Figura 18 - Réplica do meme Royal Wedding Girl.

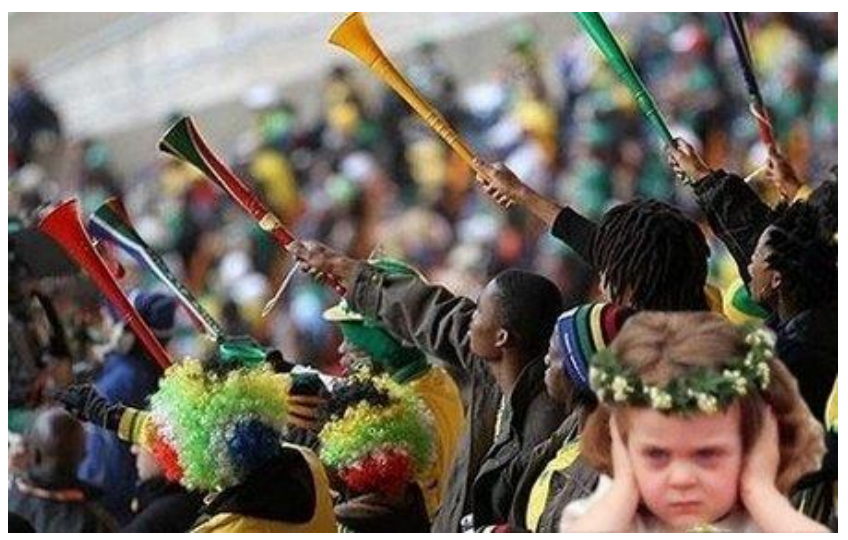

Fonte: knowyourmeme.com

Figura 19 - Réplica do meme Royal Wedding Girl.

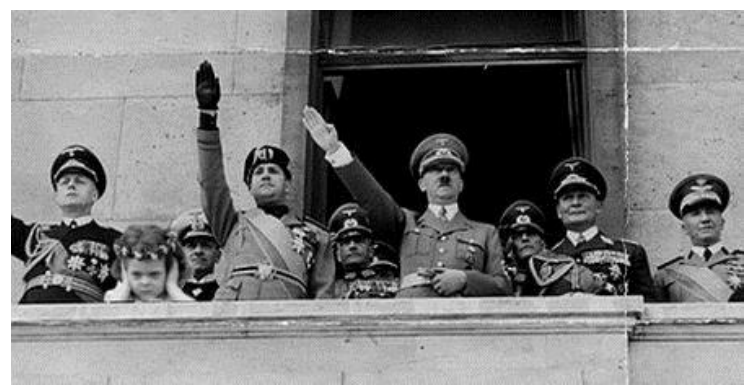

Fonte: knowyourmeme.com

Desse modo, a articulação entre textos promovida pela repetição paródica, em um dado momento no contexto comunicacional da internet, com seus processos de circulação de mensagem, permite entender certo aglomerado de textos não apenas como

100 Réplicas do meme Royal Wedding Girl disponíveis em: < http://knowyourmeme.com/memes/royalwedding-girl> Acesso em 28/1/2014. 
um conjunto de fotos, ou um grupo de vídeos ou uma série de montagens e frases sem sentido, mas sim como um meme, uma forma de expressão que determina uma maneira de conceber o mundo. Como havíamos ponderado, ainda que se tenha repetição e paródia em outras linguagens que configuram os textos culturais - como na literatura, no cinema, nas artes plásticas ou mesmo em novelas e séries de TV - esses elementos se combinam de determinada maneira de modo que esse arranjo configura um meme, uma linguagem que por meio de seus jogos, uma articulação entre regularidades da linguagem (regras) e contexto, envolve os indivíduos-coletivos em uma situação comunicativa e de entendimento do mundo. A semiosfera dos memes pode ser compreendida, assim, "como uma estrutura imersa em um mundo externo a ela que atrai esse mundo em direção a si e o expulsa reelaborado por sua própria língua" (ARÁN, 2001, p. 60).

A linguagem do meme é assim signo, consistindo em uma forma de representar e conhecer um objeto. Uma forma e não outra. A mediação desses signos no ato de comunicar, conhecer, apreender, criticar um objeto se dá de modo particular pelo meme como forma de expressão. São maneiras de compreensão e pensamento característicos da gramática e da cultura que essa linguagem envolve. Como pensamento e linguagem são indissociáveis, uma vez que nosso pensamento se dá em signos (e a linguagem é o uso desses signos), podemos dizer que o meme também configura uma forma de pensamento. As especificidades desse modo de entender o mundo da linguagem do meme veremos com mais detalhes no capítulo seguinte no qual buscaremos delinear as categorias e subcategorias que nela aparecem conformando-a como essa maneira particular de conceber a realidade. 


\title{
CAPÍTULO 4. O MEME E SEUS JOGOS
}

\author{
“O fantástico já está entre nós, basta somente empurrá-lo ainda mais além." \\ Omar Calabrese
}

ANATOMIA DE UM MEME

meme começa

não entende o meme

tweet engraçadinho

tweet emplacador

tweets forçados

resignação

reflexão sobre a vida

@ castrijon

O objetivo desse capítulo é delinear a particularidade do meme como linguagem e, portanto, forma de pensamento e cultura, estabelecendo algumas categorias que nos permitam entender seus modos de tradução criadora e especificidade.

Ao definir o meme como linguagem, como abordado nos capítulos anteriores, depreendemos que suas manifestações implicam uma forma de conceber o mundo, fundamentada em um processo de estabelecimento de hábitos, ordenamento, generalidade, decorridos de práticas comunicativas mediadas pela internet. Desta maneira, o meme comporta uma regularidade que conecta suas ocorrências, o que nos permite compreender uma pluralidade de manifestações, aparentemente muito diferentes, como atualizações de uma unidade de expressão. Essa generalidade emerge da linguagem em uso, no ato de jogar com a significação em uma situação comunicativa e em determinada temporalidade, isto é, em um jogo de linguagem.

Na observação das ocorrências meméticas, chegamos assim a dois traços que configuram o que há de regular nas ocorrências meméticas: a repetição e a paródia, elementos que tomaremos como categorias de análise primárias cuja articulação conforma o devir do meme em seu processo de (res)significar. São elas que fazem com que "o meme seja meme". A essas duas categorias estão associadas outras secundárias: 
a carnavalização, o exagero, o excesso, o absurdo e o humor, categorias que se interrelacionam com as primárias e que fazem parte da configuração da cultura do meme da internet. A partir delas, podemos entender a emergência do cômico nas relações textuais, operando como um modo de vislumbrar o mundo como algo risível, pelos “falantes” dessa linguagem. É preciso lembrar, contudo, que o riso é o efeito possível de um entendimento e que não o tomamos aqui como uma propriedade do meme. Nesse sentido, o que fundamenta o meme como linguagem é a repetição e a paródia e a articulação desses elementos em uma cultura do meme é o que permite tanto conceber o mundo de modo cômico, como perceber essa intenção de provocar o riso por parte de um emissor de um meme-

Para fundamentar algumas das categorias primárias e secundárias de análise do meme recorreremos a categorias estéticas, movimentos artísticos e gêneros textuais, que por sua vez também possuem suas próprias regularidades. Entendemos assim que no meme manifestam-se alguns traços partilhados com essas categorias de partida: o grotesco, a própria paródia enquanto gênero discursivo e o surrealismo ${ }^{101}$, nas quais buscaremos algumas matrizes de entendimento.

Evocamos, assim, o gênero paródico para compreender a apropriação que se dá no meme, formando com a repetição as duas categorias primarias que compõem o padrão memético de apreensão da realidade. Já as categorias secundárias partem do grotesco, tanto em sua atualização histórica na Idade Média e no Renascimento, quanto sua versão romântica e moderna - fundamentando-nos nesta última principalmente nos elementos do movimento surrealista que nos permitem compreender a ideia de absurdo no meme. Sublinhamos também a relevância da cosmovisão carnavalesca (base do grotesco) no devir de nosso objeto, tomando esse conceito como explicação de um "método de ressignificação" que permite uma concepção risível do mundo.

É preciso salientar que o grotesco, o surrealismo e a paródia não aparecem nesta pesquisa como uma forma classificatória para as ocorrências meméticas, mas sim como categorias de partida, como dissemos, que nos permitem entender a conformação dos interpretantes dinâmicos, das réplicas dos memes. Nossa intenção, nesse sentido, não é a de "encaixar" exemplos de memes em conceitos já formulados e fechados dessas categorias, algo que se tira do dicionário, senão entender que aspectos dos memes fazem

\footnotetext{
${ }^{101}$ Reconhecemos aqui que, diferente das duas outras categorias de partida que são atemporais, o surrealismo é um movimento localizado em ponto específico da história. Partiremos dele para entender o que o movimento tomava por "surrealidade" para então discutir a ideia de absurdidade no meme.
} 
dele um objeto paródico, surrealista ou grotesco, desconstruindo e reconstruindo o próprio entendimento dessas categorias analíticas. Assim, não aceitaremos tampouco um entendimento fechado na literatura, no teatro ou nas artes visuais, mas sim, na realidade, buscaremos elementos das definições das categorias de partida nesses contextos para entender uma outra situação: o meme da internet. Passemos às categorias de análise.

\subsection{Repetição}

Um dos elementos que permite o reconhecimento de uma manifestação no ambiente de práticas comunicacionais da internet como meme é a repetição. Esse traço, entretanto, como mostrado anteriormente, está presente em outras manifestações culturais, como na literatura, nas artes plásticas e até mesmo nos produtos mediáticos, tais como as séries de TV, filmes, novelas. Que elementos, então, configurariam um tipo particular de repetição, o traço de repetição do meme? Com que outros elementos se articula e que particularidades traz na configuração do meme como linguagem? Para responder a essas questões, caracterizaremos a repetição por três traços: a relação entre os elementos repetidos, os tipos de repetição e o ritmo que ela estabelece.

Como vimos no capítulo anterior, o devir dos memes pode ser encarado como uma semiose, na qual cada réplica (interpretante) de um meme (signo) configura uma leitura possível de uma informação (objeto). Nesse processo coletivo e dinâmico, que também entendemos como tradução criadora e que envolve certo tipo de repetição, é que se configuram entendimentos do mundo a partir da linguagem-meme.

Dawkins entendia esse processo como replicação e, na analogia com o gene, assim se daria a produção de cópias dos memes para que estes se perpetuassem na história. Diferente dos genes, entretanto, nos memes, entender as réplicas como cópias é problemático. As cópias dos memes (seja no sentido geral ou tratando-se do nosso objeto) não são exatamente imitações idênticas, isto é, uma produção de uma série de réplicas fiéis. Nesse sentido, uma cópia consiste na semelhança (se não na igualdade) entre dois elementos e, no caso do meme, as reproduções não são exatamente iguais. O próprio Dawkins reconhece que no processo de replicação sempre pode haver mutação. A questão é que nos memes da internet não só pode acontecer mutação como essa mutação é na realidade necessária. 
Desse modo, um meme, ao repetir não está simplesmente repetindo, reproduzindo, gerando cópias uniformes de si. Reflexionando, assim, sobre a relação entre os exemplares que se replicam conformando um meme, é válido asseverar que a repetição nessa linguagem sempre irá envolver certa identidade e certa diferença no que é repetido. Sempre haverá algo que conecta os exemplares de um meme e algo que faz com que eles não sejam idênticos uns aos outros. É possível afirmar que essa repetição com diferenciação se deve porque a incidência do meme é também paródica (uma segunda categoria que veremos a seguir), ocorrendo assim pela apropriação de um elemento que é em seguida reinterpretado parodicamente, originando uma série de "cópias não idênticas". Observamos também que a serialidade no meme não implica uma ordem sequencial necessária: tem-se um primeiro meme nem sempre identificável (e cuja identificação também parece não receber importância) e dele segue um conjunto de outros em uma forma de repetição que é, em certo sentido, desordenada, desenfreada e se caracteriza pela diferenciação dos elementos que compõem essa repetição, decorrendo aleatoriamente (com respeito uns aos outros).

Se repetição e paródia estão na configuração primária de um meme, podemos pensar em dois tipos de repetição, que mencionamos brevemente quando abordamos que há um acordo entre os "falantes" a respeito da interpretação das regras. Esse acordo é o que permite compreender fenômenos que, em um primeiro olhar são completamente diferentes, mas que na compreensão de suas regras, nos permite reuni-los como fenômenos do mesmo tipo. Desse modo, identificamos, em nossas observações, dois tipos de manifestação memética, que, para simplificar e tornar claro o que entendemos como meme da internet, chamaremos de repetição da forma e repetição do conteúdo (ainda que por vezes a repetição formal envolva também a repetição de um conteúdo, de um tema).

O primeiro desses tipos revela um modelo bem delimitado, isto é, são memes nos quais transparece a existência de um padrão formal, e na presença de texto verbal, um padrão discursivo. Não se trata, porém, de uma estrutura engessada, pois o modelo que serve de base para esses memes permite, dentro de seus limites, a recriação. Como exemplo de formação memética que apresenta estes traços, temos o Doge (Figuras 20 a 22), meme cujo modelo base consiste em uma imagem de um cão da raça shiba, cercado por suas reflexões escritas na fonte comic sans, contendo erros ortográficos e gramaticais. Nessas ocorrências, existe um padrão que já está dado e pode-se criar dentro deste template, observando as "normas" da forma, isto é, desse modelo. 
Figura 20 - Réplica do meme Doge.

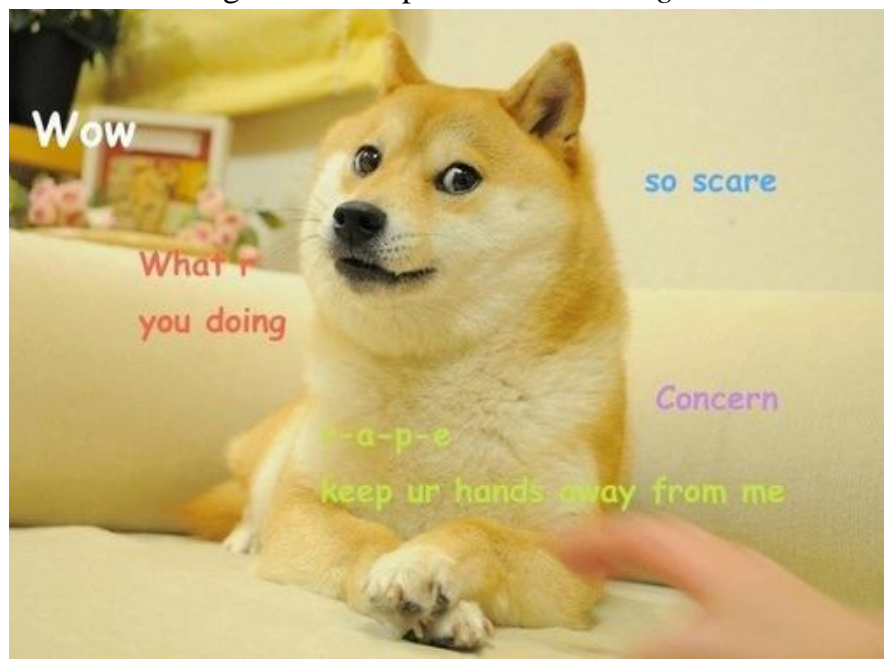

Fonte: knowyourmeme.com.br ${ }^{102}$.

"uau/o que você está fazendo?/tão assustado/preocupado/-m-ac-a-c-o mantenha suas mãos longe de mim".

Figura 21 - Réplica do meme Doge.

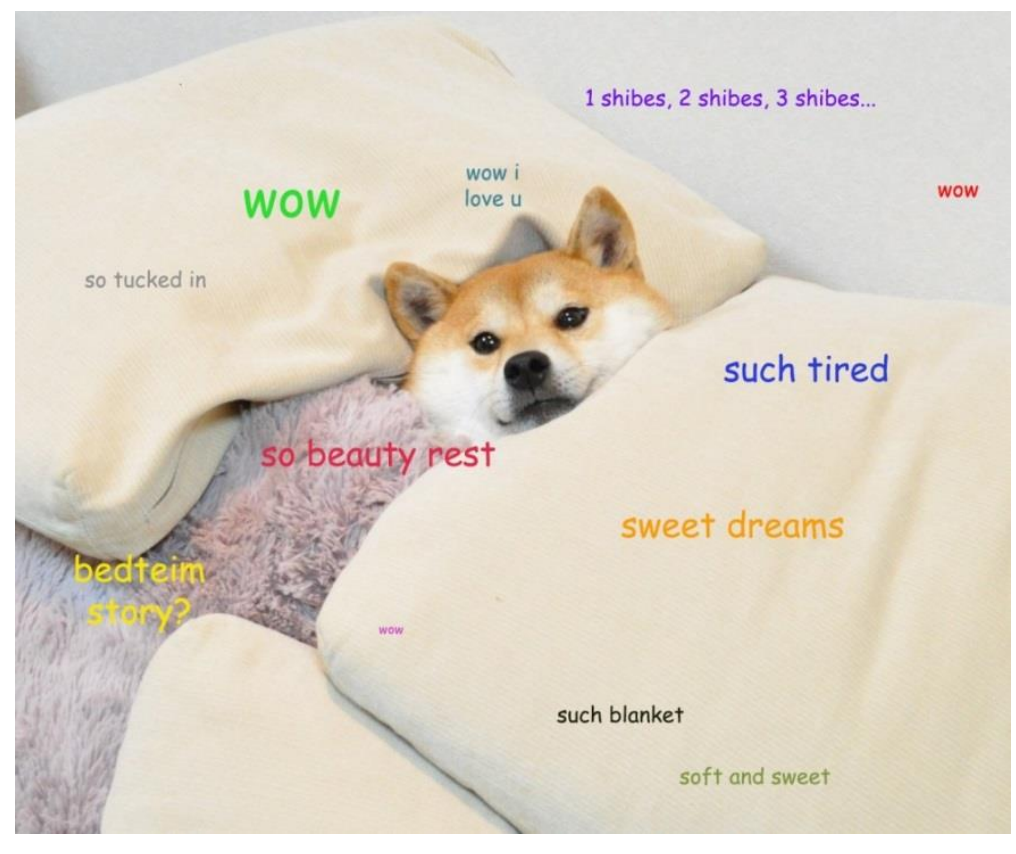

Fonte: reddit.com ${ }^{103}$

"1 shibas, 2 shibas, 3 shibas/ uau/uau eu amo você/uau/tão aconchegante/tão cansado/tão sono de beleza/tenha bons sonhos/historinha para dormir?/uau/tão cobertor/doce e suave".

$102<$ http://knowyourmeme.com/memes/doge> Acesso em 1/9/2014.

103 <http://www.reddit.com/r/SuperShibe/comments/1ijfjq/wow_sleepy_doge/> Acesso em 1/9/2014. 
Figura 22 - Réplica do meme Doge.

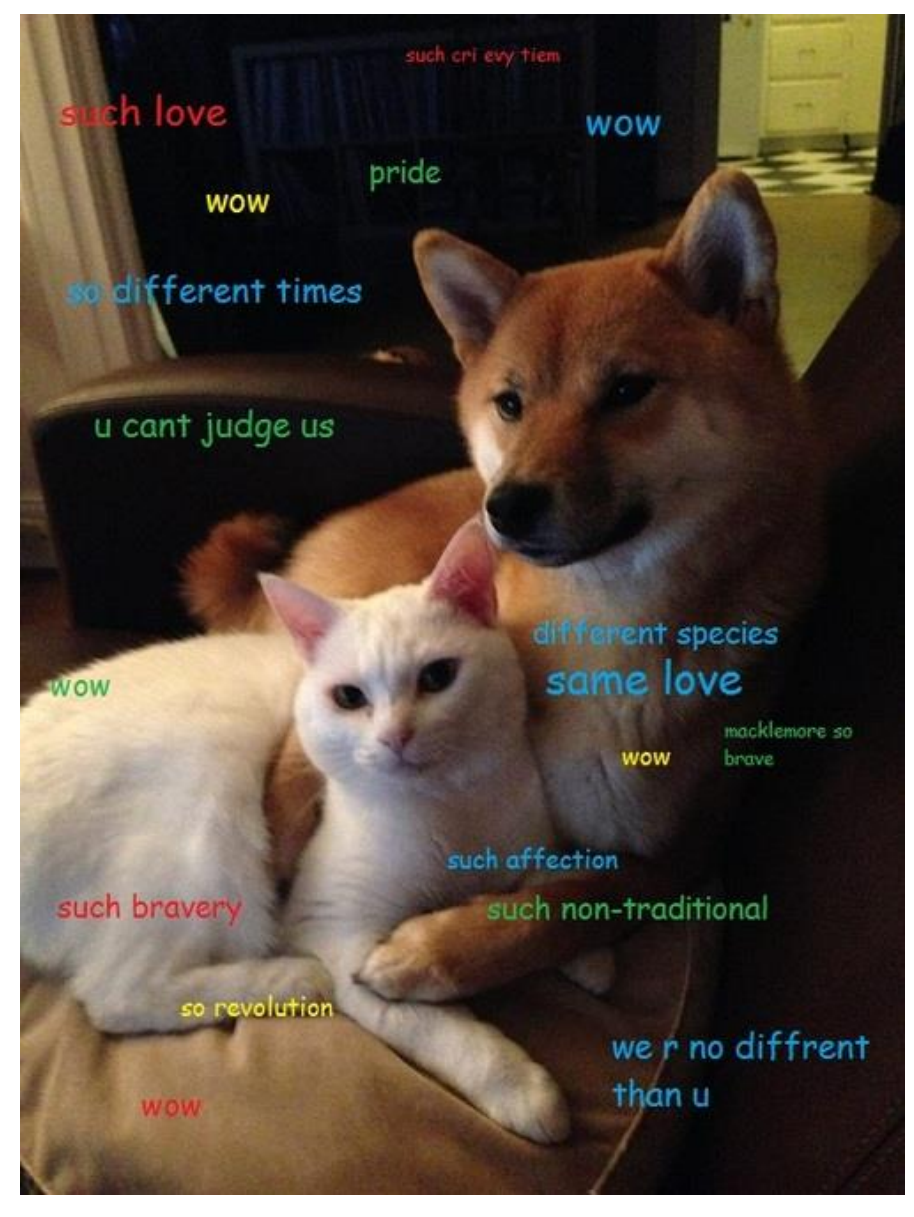

Fonte: imgur.com ${ }^{104}$

"Tão choro toda vez/tamanho amor/uau/orgulho/uau/tempos tão diferentes/você não pode nos julgar/espécies diferentes mesmo amor/uau/Macklemore tão corajoso/tamanha afeição/tão não-tradicional/tamanha coragem/tão revolução/ nós não somos diferentes de você/uau".

Já em outras manifestações, também chamadas de meme, a repetição da forma não parece ser imprescindível. Não obstante, há de todo modo certo tipo de repetição, trata-se, contudo, de uma repetição temática, uma repetição do conteúdo, se podemos colocar nesses termos. A menção exaustiva a determinado assunto, entretanto, não faz de uma informação circulante na web um meme da internet. Se assim fosse, qualquer assunto polêmico ou notícia de grande repercussão seriam chamados de meme na rede. O que observamos é que, para que essa recorrência temática seja considerada um meme, exige-se uma produção textual desenfreada baseada na recriação a partir de outros textos, uma recriação que é paródica, por assim dizer. Como exemplo, podemos tomar as reações na internet durante toda a Copa do Mundo de 2014. Aqui ilustramos com a

\footnotetext{
104 < http://imgur.com/gallery/ccvI6UJ > Acesso em 1/9/2014.
} 
repetição temática da derrota do Brasil pela Alemanha na semifinal, com um placar histórico de 7 a 1, para os alemães (Figuras 23 a 28).

Figura 23 - Réplica do meme $7 x 1$.

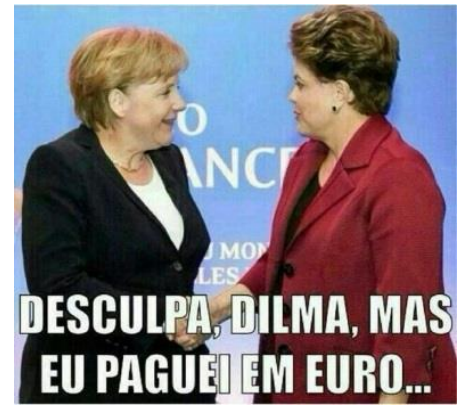

Fonte: www.inexistentman.net ${ }^{105}$

Figura 24 - Réplica do meme $7 x 1$.

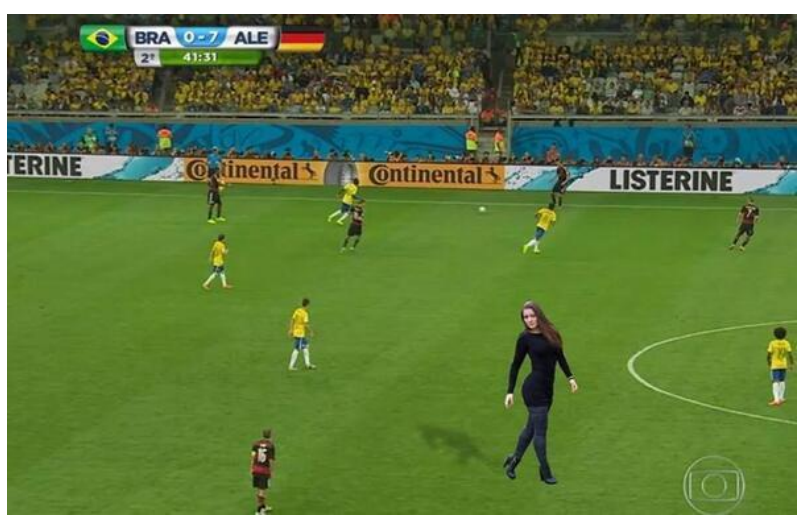

Fonte: www.inexistentman.net ${ }^{106}$

Figura 25 - Réplica do meme $7 x 1$.

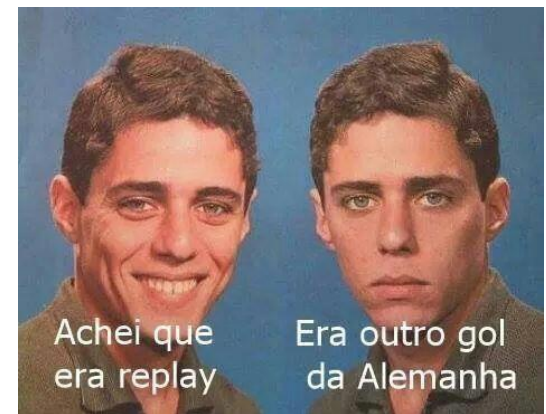

Fonte: www.inexistentman.net ${ }^{107}$

\footnotetext{
105 <http://www.inexistentman.net/2014/07/os-melhores-memes-da-derrota-brasil-alemanha-7-x-1-brasil-copamundo-2014/> Acesso em 1/9/2014.

$106<$ http://www.inexistentman.net/2014/07/os-melhores-memes-da-derrota-brasil-alemanha-7-x-1-brasil-copamundo-2014/> Acesso em 1/9/2014.

$107<$ http://www.inexistentman.net/2014/07/os-melhores-memes-da-derrota-brasil-alemanha-7-x-1-brasil-copamundo-2014/> Acesso em 1/9/2014.
} 
Figura 26 - Réplica do meme $7 x 1$.

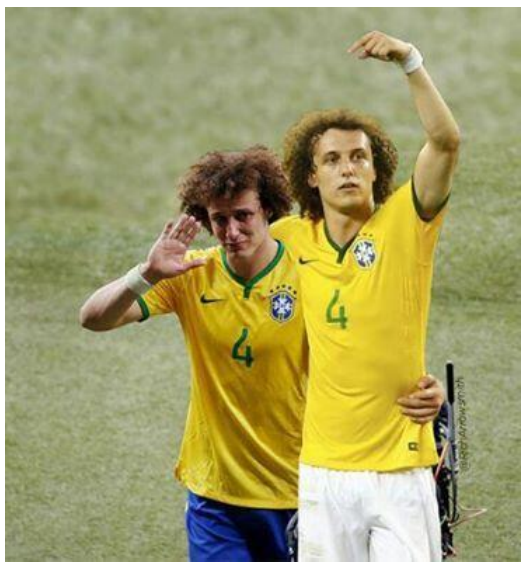

Fonte: knowyourmeme.com ${ }^{108}$

Figura 27 - Réplica do meme $7 \times 1$.

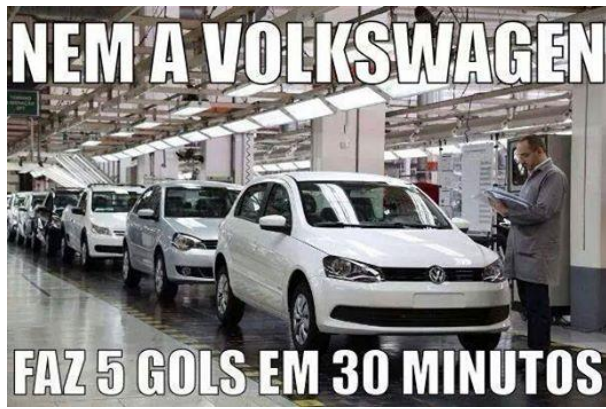

Fonte:videmula.com.br ${ }^{109}$

Figura 28 - Réplica do meme $7 x 1$.

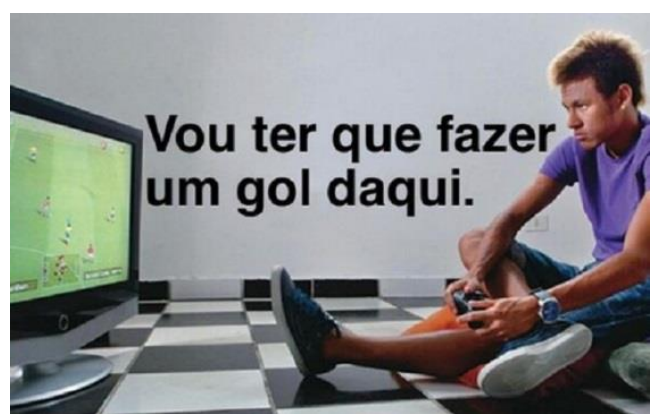

Fonte: youpix.virgula.uol.com.br ${ }^{110}$

108 <http://knowyourmeme.com/photos/790486-2014-world-cup-semfinal-brazil-vs-germany> acesso em $1 / 9 / 2014$

$109<$ http://videmula.com.br/n/> Acesso em 1/9/2014

$110<$ http://youpix.virgula.uol.com.br/fun/os-melhores-memes-de-alemanha-7-x-1-brasil/> Acesso em 1/9/2014 
Assim, ainda que essas manifestações apresentem aspectos diversos e nenhum modelo específico que lhes sirva de base para a sua sequente difusão profusa, podemos tomá-los como meme por apresentarem a repetição e a recriação (paródica) das imagens da Copa produzidas pela imprensa, por exemplo.

Nesse sentido, no meme, o repetitivo não está associado a uma ideia de falta de originalidade, pois a repetição envolve sempre um elemento que figura em todas as réplicas conectando-as e a criação de algo diferente. Em conjunto com a recriação paródica, configuram-se, assim, dois tipos de repetição que separamos instrumentalmente, pois nem sempre aparecem nas ocorrências meméticas de maneira pura e tão visível. Independente de sua classe, a repetição irá apresentar também uma cadência, pois algo que reincide no tempo cria seus contornos frequenciais, o que entenderemos aqui como o ritmo da repetição memética.

Como vimos, a repetição no meme se articula com a recriação (paródia) de modo que essa recriação de um objeto (que podem ser entendidas como leituras desse objeto) que se repete excessivamente conforma um meme da internet. Nesse sentido, podemos dizer que a linguagem do meme da internet é uma linguagem que opera nos limites (nesse caso, nos limites do que algo pode significar), experimentando o excesso pela repetição (quantidade) e pela paródia (qualidade, modos de trabalhar nos limites do que já está convencionado, estabelecido). Em outras palavras, nos memes, o ato de ressignificar uma informação repetidas vezes, de maneira paródica e de modo excessivo cria um tensão, uma situação de cúmulo, na qual o objeto ao ser interpretado é levado a sair de sua normalidade.

O processo de repetição possui, desse modo, um clímax, um momento em que há quase um esgotamento da ideia trabalhada no meme durante a recriação, mas é um esgotamento que não se concretiza. É como se depois desse clímax o processo de recriação se enfraquecesse, o que fica aparente com uma diminuição no ritmo e na quantidade de repetições. É curioso observar que isso se expressa graficamente, como podemos ver nos diagramas abaixo (Gráficos de 1 a 3), extraídos de uma pesquisa simples de termos buscados no Google Trends ${ }^{111}$, ferramenta que indica o interesse em

\footnotetext{
${ }^{111}$ O Google Trends é uma ferramenta criada para estratégias de marketing, para auxiliar o usuário a entender como as pessoas procuram pela marca de sua empresa, quando essas buscas apresentam picos, além de fornecer informações também sobre o interesse do público nas marcas competidoras. A ferramenta utiliza dados de busca em tempo real para ajudar a mensurar o comportamento de pesquisa do consumidor ao longo do tempo. Fonte: <https://www.thinkwithgoogle.com/tools/google-trends.html> Acesso em 5/1/2015.
} 
determinado assunto ao longo do tempo a partir da busca de determinado termo no Google.

Gráfico 1 - Interesse pelo termo "desespero da veja".

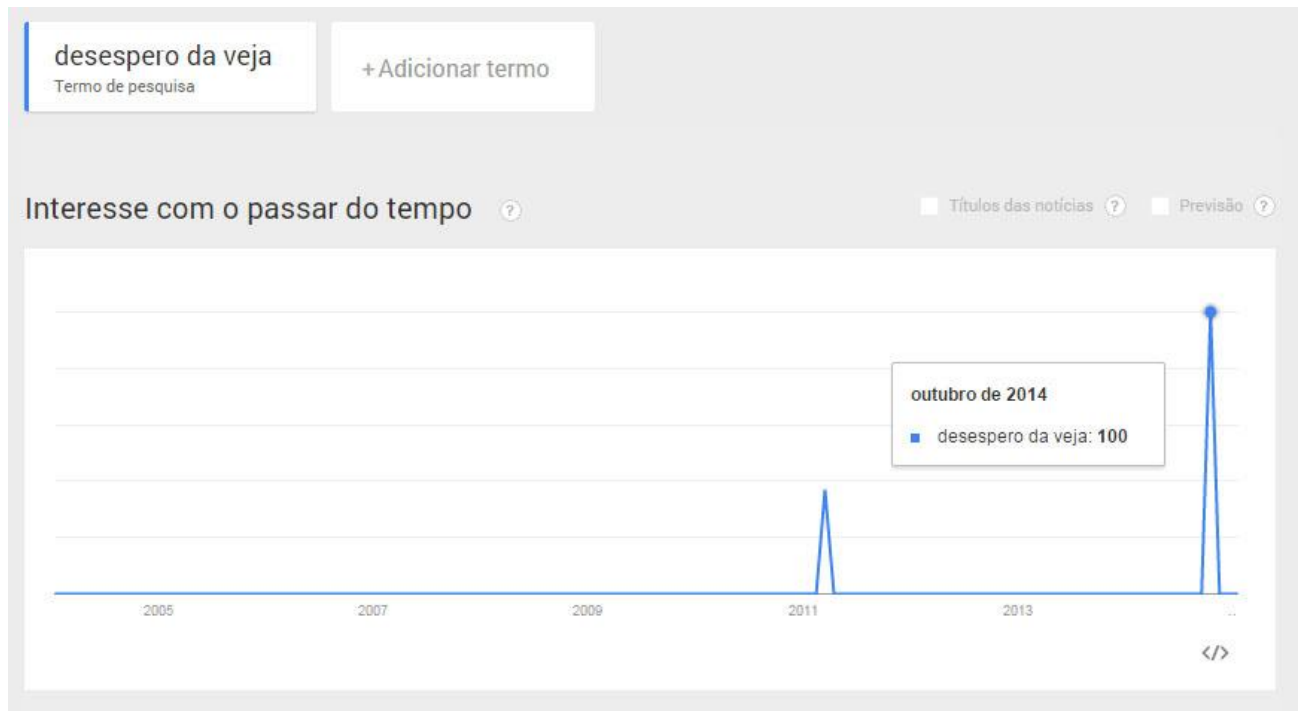

Fonte: google.com.br/trends/ $/{ }^{12}$

Gráfico 2 - Interesse pelo termo "dramatic chipmunk".

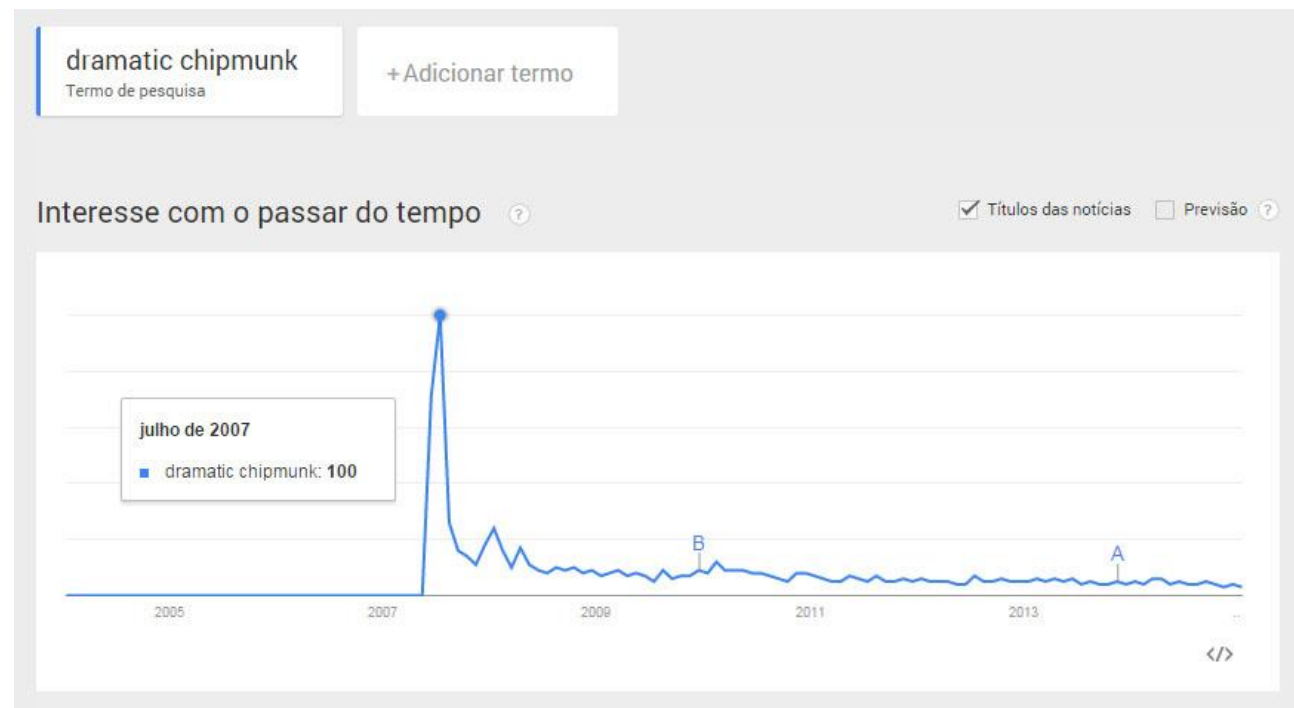

Fonte: google.com.br/trends/

${ }^{112}$ Buscas realizadas no dia 5/1/2015. 
Gráfico 3 - Interesse pelo termo “doge”.

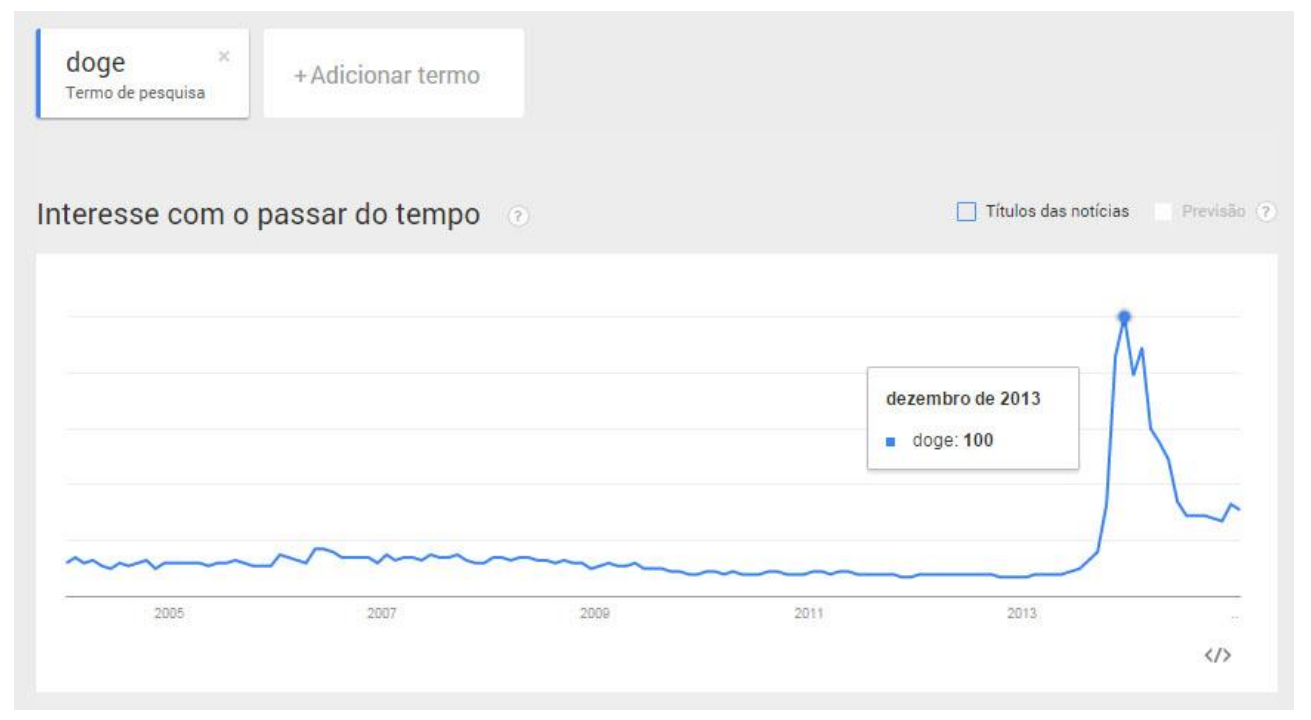

Fonte: google.com.br/trends/

Nesse sentido, as repetições de um meme se dão de modo instantâneo, "no calor" da criação coletiva, configurando um apogeu memético, passando em seguida para um declínio. Ser meme implica, desse modo também, estar nessa tensão, que em um dado momento é fervilhante e, rapidamente, em outro, pode deixar de ser. Fica o registro do meme nas redes sociais, nos fóruns, na memória da cultura. Por não se esgotar, ele permanece em aberto, de modo que não pensamos na ideia de um último meme, pois ele contém em si a possibilidade de gerar sempre mais e mais réplicas. Podemos dizer que o meme se dá em sua incompletude, em seu inacabamento. Dessa forma, pode ressignificar algo de maneira potencialmente ilimitada, sendo alguns até mesmo recuperados por vezes depois do declínio. Contudo, sua pujança parece não ser perpétua, mas sim instantânea, de modo que o meme pode "sair de moda" relativamente rápido.

A repetição do meme pode conduzir assim as leituras de mundo expressas em suas réplicas a um ápice, envolvendo sempre diferenciação entre uma cópia e outra, podendo haver a repetição constante de um modelo ou simplesmente de um tema. Como vimos também de modo breve, as réplicas nas ocorrências meméticas envolvem sempre uma recriação, o que implica na transformação de algo já criado, por assim dizer. Nesse sentido, as diferenças entre as réplicas são possíveis dado que cada uma pode ser tomada como uma apropriação diferente de uma mesma imagem, vídeo, frase, publicidade, notícia, entre outros. Apropriação e recriação encontram-se em um mesmo processo, que iremos deslindar a partir da categoria da paródia a seguir, também 
lançando luz aos modos de tender ao limite desse gênero discursivo que nos serve de janela heurística.

\subsection{Paródia}

Ao discutir o princípio de repetição no meme ressaltamos que ao "replicar" algo por essa linguagem não se está simplesmente produzindo uma cópia. Isto decorre do fato que para ser reconhecida como meme determinada manifestação cultural dar-se-á por uma gama de exemplares diferentes com respeito uns aos outros, uma vez que suas formações envolvem apropriação e recriação por meio de novas combinações, que na tradição teórica da cibercultura aparecem em termos como remix ${ }^{113}$ e spoof ${ }^{114}$. Desse modo, por meio do apropriação de uma informação, da sua reconfiguração na combinação de elementos heterogêneos, o meme, com sua natureza intertextual, acaba perturbando uma ordem já estabelecida, transgredindo uma maneira já existente de representar o mundo, ao mesmo tempo sem apagá-la totalmente da representação. Na observação desse processo, podemos aproximar nosso objeto da forma do discurso parodístico, que aqui tomamos como base para uma discussão dessa maneira particular de agir dos memes da internet.

O que faculta essa discussão a respeito da conformação do meme a partir de um conceito de paródia, assim, é o caráter apropriador desse gênero discursivo, que encerra na mesma representação um texto original e algo dissonante a ele, traduzindo-se em uma releitura desse texto, sendo, portanto, um gênero que pressupõe a recriação e a recontextualização de uma obra,

[...] uma representação de uma "realidade modelada" que já é ela mesma uma representação particular de uma realidade original. A representação paródica expõe as convenções do modelo e desnuda seus dispositivos por meio da coexistência de dois códigos na mesma mensagem. (BEM-PORAT, 1979, p. 257, tradução nossa ${ }^{115}$ ).

A paródia possui, portanto, a particularidade de ser a representação de algo que já é uma representação do mundo, suportando em sua estrutura a presença de textos de codificações diferentes, sendo todos explicitados no texto paródico que os reúne. Dessa

\footnotetext{
113 “Conjunto de práticas sociais e comunicacionais de combinações, colagens, cut-up de informação a partir das tecnologias digitais" (LEMOS, 2005).

114 "Termo utilizado na Internet, principalmente entre os falantes do inglês para de referir às paródias ou emulações irônicas de um vídeo" (FONTANELLA, 2009a, p. 3).

115 "[...] a representation of a "modelled reality," which is itself already a particular representation of an original "reality." The parodic representations expose the model's conventions and lay bare its devices through the coexistence of the two codes in the same message".
} 
maneira, podemos pensar que há um princípio paródico que conduz o devir das ocorrências meméticas, não só em sua criação inicial (a criação de um primeiro exemplar do meme), mas também em suas réplicas, considerando tanto os memes em que há uma repetição de conteúdo como uma repetição de forma, relembrando aquela separação instrumental que sugerimos. Nesse sentido, tendo em vista os memes nos quais há uma repetição de conteúdo (e formas variadas), a paródia nos oferece uma base de entendimento que permite discutir a incorporação de uma informação e sua modificação (recriação). Já nos memes em que há uma repetição da forma, podemos pensar a sua criação inicial nessa mesma lógica de incorporação e suas réplicas como repetições paródicas do modelo.

Apesar de ser definida por alguns autores como detentora de uma natureza cômica, a paródia não se determina como tal. Como destaca Linda Hutcheon inúmeras vezes na sua análise de manifestações da paródia nas formas de arte do século XX, não há nada na ideia de paródia que inclua necessariamente o humor ou o ridículo. $\mathrm{O}$ conceito de paródia, no entanto, perpassa por essas ideias, podendo ela ser uma crítica séria ou mesmo uma zombaria, uma vez que "o seu âmbito intencional vai da admiração respeitosa ao ridículo mordaz" (HUTCHEON, 1985, p. 28). Dessa forma, reconhecemos que entendida de uma maneira ampla, como faz Hutcheon em sua análise, a paródia não se define a rigor pelo escárnio de determinado objeto ou mesmo pela comicidade, isto é, o que faz de uma paródia uma paródia, não é necessariamente a presença desses elementos. Entretanto, ela enseja o ridículo, a chacota, o cômico, o humor, podendo ser um recurso para atingir o riso, como veremos mais adiante. Posto isso, na compreensão alargada do conceito de paródia, sua natureza está, portanto, na ironia e não no cômico (ibidem, p. 70-72), ainda que a paródia permita por essa ironia uma apreensão risível da realidade. Para entender essa relação entre cômico e irônico na incidência da paródia, parece-nos necessário desenredar uma possível confusão terminológica pelo fato de o termo "ironia" também ser utilizado no contexto da comicidade, do riso.

A ironia, na linguagem verbal, enquanto um fenômeno semântico, consiste na "oposição entre um sentido pretendido e afirmado" ou, simplesmente, na "marcação de um contraste" (ibidem, p. 73). Desse modo, essa figura retórica pode ser entendida como a sobreposição de contextos semânticos, isto é, a justaposição entre algo que é afirmado e o que se pretende dizer (um significado intencionado). Sugere-se, assim, um paralelismo, no qual a ironia (verbal), em um nível microcósmico, semântico, corresponde à paródia em um nível macrocósmico, textual, uma vez que esta também 
consiste em um assinalar de diferenças, igualmente por meio da sobreposição. Na paródia, entretanto, trata-se de uma de uma sobreposição de contextos textuais (ibidem, p. 74). Entendendo a ironia no conceito de paródia, portanto, podemos vislumbrar esse gênero discursivo como uma dupla afirmação (manifestação) textual: a ironia da paródia está no fato de que ela se afirma como o texto que é e, ao mesmo tempo, é a afirmação de outros textos (os textos parodiados).

A natureza irônica da paródia estaria, nesse sentido, no jogo intertextual que ela estabelece, no qual um potencial para ser risível se inscreve na heterogeneidade dos contextos textuais simultaneamente afirmados, como na união da arte e de sua "negação" no meme Ecce Mono. Essa manifestação memética foi motivada por uma imagem (Figura 29) publicada em um pequeno artigo do blog do Centro de Estudios Borjanos que noticiava a má restauração de uma pintura do século XIX, de Elías García Martínez. A obra Ecce Homo, que está no Santuario de La Misericordia, em Borja, na Espanha, foi restaurada por Cecília Giménez, uma senhora de 80 anos (na época do acontecimento), que decidiu reparar a pintura sem autorização.

Figura 29 - Antes e depois da restauração da obra Ecce Homo.

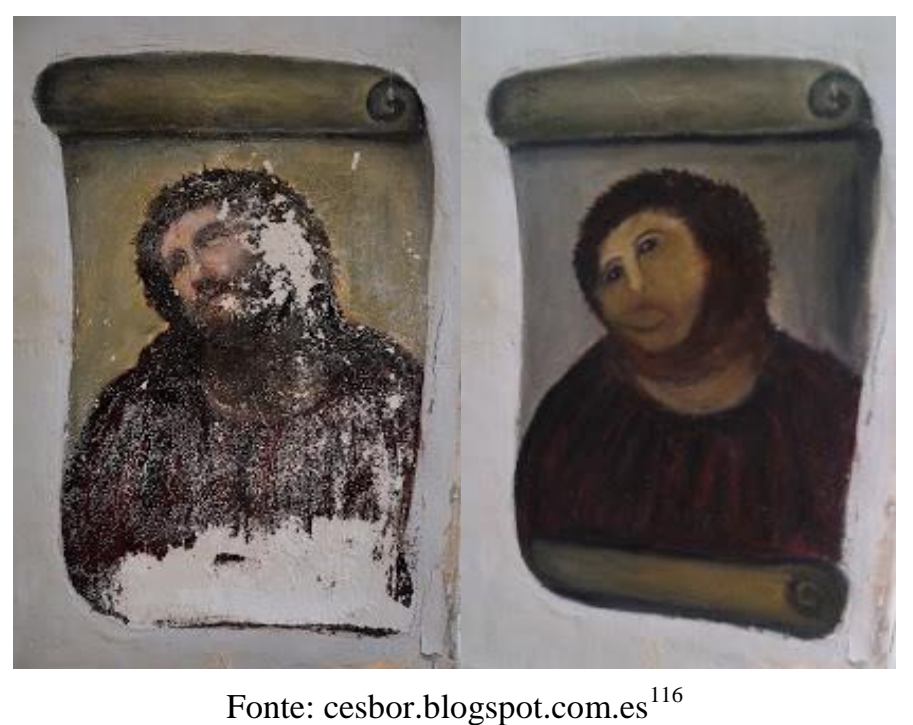

A notícia percorreu a internet e a obra passou a ser conhecida como Ecce Mono (mono, que em espanhol significa "macaco") e Potato Jesus (“Jesus de Batata”), ganhando perfis no Facebook e no Twitter, além de inúmeras paródias em montagens diversas. As que observamos haver certa constância são as réplicas em que o rosto de Jesus, na obra Ecce Homo, é sempre substituído por outro rosto (Figura 30); imagens

\footnotetext{
${ }^{116}<$ http://cesbor.blogspot.com.es/2012/08/un-hecho-incalificable.html> Acesso em 28 /1/ 2014.
} 
que fazem referência a outras obras de arte (Figuras 31 e 32); e montagens com imagens nas quais figuram Jesus Cristo, cujo rosto é sempre substituído pela pintura de Cecília Giménez (Figuras 33 e 34).

Figura 30 - Réplicas do meme Ecce Mono.

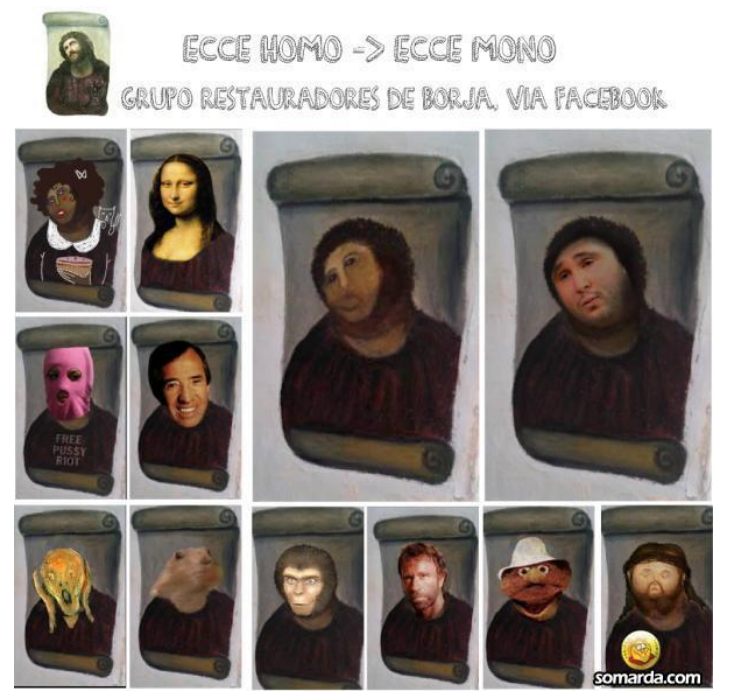

Fonte: www.youpix.com.br ${ }^{117}$

Figura 31 - Réplica do meme Ecce Mono.

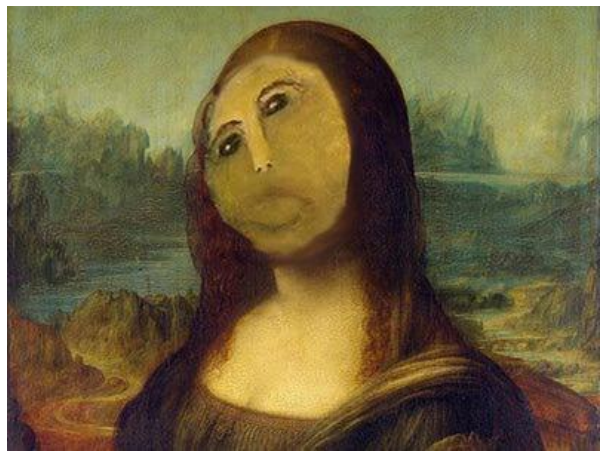

Fonte: www.animalpolitico.com ${ }^{118}$

Figura 32 - Réplica do meme Ecce Mono.

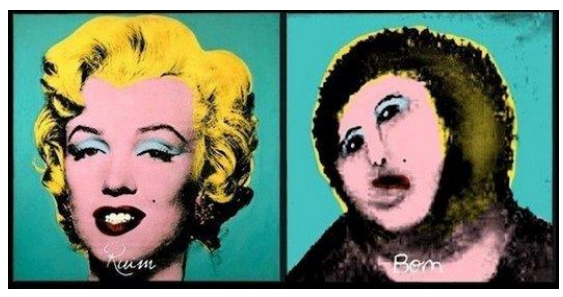

Fonte: artislimited.wordpress.com ${ }^{119}$

\footnotetext{
117 <http://www.youpix.com.br/memepedia/meme-do-momento-restauracao-fail-ecce-mono/> Acesso em $28 / 1 / 2014$

${ }^{118}<$ http://www.animalpolitico.com/2012/08/del-ecce-homo-al-ecce-mono-la-pintura-malrestaurada/\#axzz2rneQ8w8b> Acesso em 29/1/2014.
} 
Figura 33 - Réplica do meme Ecce Mono.

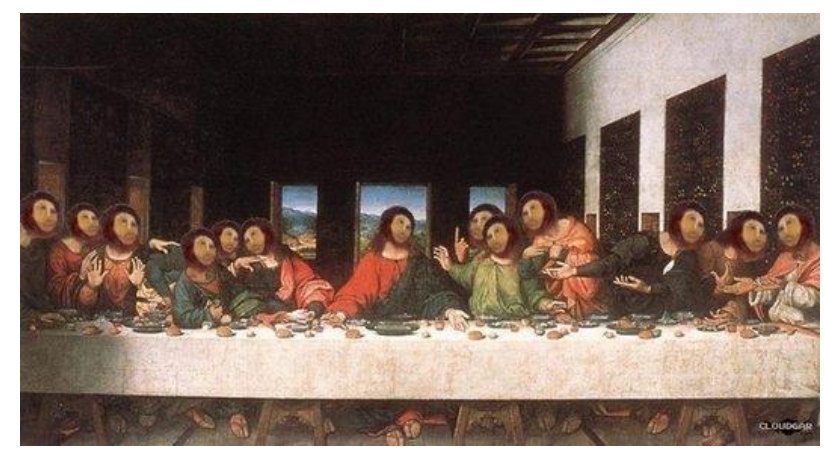

Fonte: knowyourmeme.com ${ }^{120}$

Figura 34 - Réplica do meme Ecce Mono.

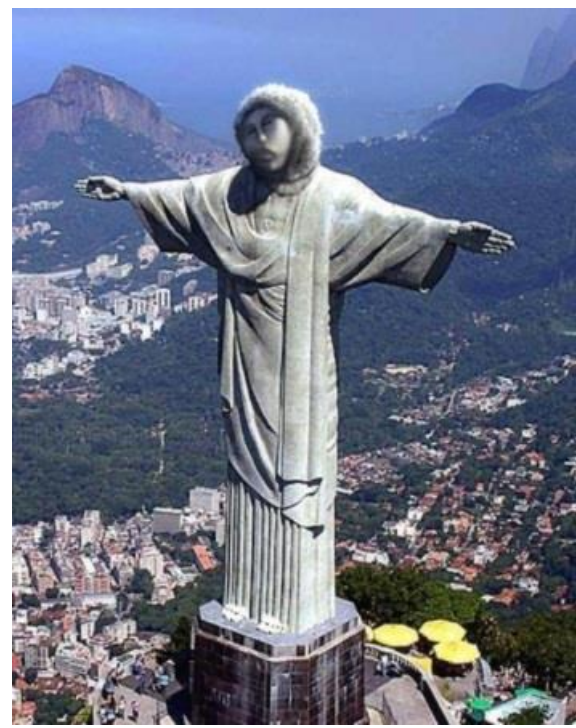

Fonte: vejasp.abril.com.br ${ }^{121}$

As imagens ilustram, assim, a combinação de alteridade e incorporação que caracteriza a paródia: ser, ao mesmo tempo, ela mesma e outros textos dos quais ela se apropria, como em um de nossos exemplos, ser a paródia, o Cristo Redentor e a restauração de Ecce Homo simultaneamente. Nesse meme, nas suas variadas manifestações, transparece a síntese de contextos textuais, contudo uma síntese intertextual não consonante, uma vez que as montagens resultam na junção disparatada de imagens e seus contextos de produção. Nesse sentido, a apropriação do meme é paródica, mais que parafrásica (ou citatória), pois a incorporação e sobreposição de

\footnotetext{
$119<$ http://artislimited.wordpress.com/2012/08/25/yesterday-we-posted-about-a-restoration-project-gone-awrytoday-its-the-internets-favorite-art-meme/> Acesso em 29/1/2014.

120 < http://knowyourmeme.com/memes/events/botched-ecce-homo-painting > Acesso em 29/1/2014.

$121<$ http://vejasp.abril.com.br/blogs/pop/2012/12/20/cecilia-a-pior-restauradora-do-mundo-vira-estrela-emanuncio-de-tv/> Acesso em 29/1/2014.
} 
textos cria uma tensão, culminando em uma intertextualidade das diferenças, mais que das semelhanças. Produz-se, nesse sentido, um efeito de deslocamento, em vez de condensação, como nos mostra Sant'Anna na distinção entre paródia e paráfrase: “com a condensação, temos dois elementos que equivalem a um. Com o deslocamento temos um elemento com a memória de dois" (SANT'ANNA, 1988, p. 28).

Ser paródico, contudo, não é uma determinação localizada somente nessa síntese intertextual. O conceito de paródia é relativo ao leitor (ibidem, p. 26) e o não reconhecimento do intertexto suprime o efeito paródico. Nesse sentido, a paródia se estabelece na relação do leitor com o texto e, como acrescenta Hutcheon, incluindo também a intencionalidade codificada e depois inferida, bem como a competência semiótica do leitor nessa relação (HUTCHEON, 1985, p. 79), o que Hutcheon nomeia de ethos da paródia, em uma abordagem do conceito a partir da situação comunicativa criada pelos textos literários:

Por ethos entendo a principal resposta intencionada conseguida por um texto
literário. A intenção é inferida pelo descodificador, a partir do texto em si.
Sob alguns aspectos, pois, o ethos é a sobreposição do efeito codificado (tal
como é desejado e pretendido pelo produtor do texto) e do efeito
descodificado (tal como é obtido pelo descodificador). [...] Um ethos é, pois,
uma reação intencionada inferida, motivada pelo texto. (HUTCHEON, 1985,
p. 76).

Para a autora, o ethos da paródia deveria ser rotulado de "não marcado, com uma série de possibilidades de ser marcado" (ibidem, p. 79), podendo, assim, ser tanto ridicularizador, como detentor de uma marcação positiva de homenagem ao texto parodiado, bem como uma marcação galhofeira não agressiva - diferente da sátira, por exemplo, que possui um ethos bem definido, sendo desdenhoso ou escarnecedor (ibidem, p. 76-80). A paródia, assim, permite as diversas marcações de ethos e conta com a possibilidade de se sobrepor a outros gêneros, uma vez que um estado de gêneros hipoteticamente puros raramente se concretiza na prática. Assim, como destaca Hutcheon, a paródia não deve ser entendida como um modo de simbiose parasitária, mas pensada ao nível formal como uma "estrutura paradoxal de sínteses de contrastes, uma espécie de dependência diferencial de um texto em relação a outro" (ibidem, p. 81).

Em relação ao nosso objeto, podemos inferir que os textos originados pela linguagem do meme, compreendidos nas situações comunicativas de seus proferimentos, localizados em determinado contexto cultural, possuem um ethos que se definiria pelo risível. Esse ethos é alcançado pelo contraste de textos e contextos por meio da apropriação paródica das representações da realidade, postas em diálogo nas 
ocorrências meméticas. Atingir o risível, no entanto, como vimos, pressupõe um conhecimento partilhado, que não é parte do saber do "locutor" ou do "destinatário", mas sim parte de um saber mútuo (LOZANO, 1995), isto é, uma memória comum, a inserção em uma semiosfera que permita a determinada compreensão e não outras realizáveis. Somente assim a existência de um ethos, que reúne a intenção do autor e a reação esperada do receptor, torna-se possível, mas não necessariamente certeira, uma vez que a incompreensão também faz parte da ação do signo. Na perspectiva do leitor, a apreensão dessa "intenção codificada" se dará, assim, não apenas pelo domínio da linguagem, mas também graças à observação colateral que permite que o leitor ponha em diálogo com o texto apreendido outros textos (outros signos), como discutido no capítulo 3. Desse modo, a observação colateral, a memória partilhada, o recorte contextual da semiosfera e o processo inferencial do leitor na interpretação ensejam a apreensão de uma intenção de parodiar do autor, guardados os possíveis graus de incompreensão. O riso a partir de um meme será, assim, resultado de determinada compreensão, sendo, por conseguinte, um efeito possível do entendimento, mas não necessário. Logo, o que torna o meme risível não é só a incongruência dos elementos nele presentes, mas também a compreensão contextual que rodeia esse contraste e certa familiaridade com a linguagem. Esses elementos fazem o leitor e o autor do meme aceitarem ser parte desse jogo de intertextos.

Se o efeito paródico, para realizar-se, demanda um reconhecimento do texto parodiado, depreende-se que a paródia, ao passo que é ruptura ao propor uma síntese de heterogeneidades, é também continuidade, no sentido de sempre repetir algo do texto parodiado em sua encarnação. Dessa maneira, a paródia cria uma tensão entre lei e transgressão:

\footnotetext{
Este paradoxo da subversão legalizada, embora não oficial, é característica de todo o discurso paródico na medida em que a paródia postula, como prérequisito para a sua própria existência, uma certa institucionalização estética que acarreta a aceitação de formas e convenções estáveis e reconhecíveis. Estas funcionam como normas ou regras que podem ser - e logo, evidentemente, serão - quebradas. Ao texto paródico é concedida uma licença especial para transgredir os limites da convenção, mas, tal como no carnaval, só pode fazê-lo temporariamente e apenas dentro dos limites autorizados pelo texto parodiado - quer isto dizer, muito simplesmente, dentro dos limites ditados pela "reconhecibilidade". (HUTCHEON, 1986, p. 95)
}

O meme, dessa maneira, por seu aspecto paródico, assim como por sua regularidade de repetição, permite experimentar o excesso e empurrar os confins de um sistema, extirpando o objeto representado de sua normalidade. O trabalho paródico no 
meme realiza-se assim por meio do que Omar Calabrese chama de excentricidade: "um excêntrico é [alguém] que atua nos limites de um sistema ordenado, mas sem ameaçar sua regularidade" (CALABRESE, 1999, p. 72, tradução nossa ${ }^{122}$ ). O autor ilustra o que toma por excentricidade a partir do exemplo do sistema da moda:

É assim excêntrico o estilo casual, o "punk" revisado e corrigido, o enfeite esquisito colocado em um traje tradicional, o uso de inverter os "uniformes" tradicionalmente adequados para determinadas ocasiões (utilizar jeans para uma cerimônia e "smoking" para um passeio. (idem, tradução nossa ${ }^{123}$ )

Na moda, a excentricidade pressiona às margens da ordem, mas sem tocar na ordem, porque a excentricidade está prevista pelo organismo superior das regras de vestir (idem). De modo similar, podemos inferir que no meme, a partir da paródia, a excentricidade também funciona como ordem - transgredir, transformar e mudar são parte da regularidade dessa linguagem, funcionam como regra. Dessa maneira, o meme opera levando o texto parodiado (o que ele toma como objeto) para o seu limite por meio da ressignificação, que consiste em quebrar convenções e ao mesmo tempo mantêlas, observando os limites da "reconhecibilidade", como alerta Hutcheon.

Desse modo, a paródia segue uma ordem na identificação com o outro, mas é também contestadora em sua ânsia de se distinguir desse outro. Há, portanto, nesse gênero discursivo, uma repetição com diferenciação e o meme, enquanto detentor de um princípio paródico, também toma o rompimento com uma ordem como lei. O desvio, assim, em uma ocorrência memética, pelo excesso de repetições, torna-se de certa forma uma norma. Ilustrando aqui com um erro de tradução (Figura 35) que se tornou padrão, regra, para a criação das réplicas do meme Placas da Copa $^{124}$ (Figuras 36 a 39).

\footnotetext{
122 “Un 'excéntrico' es un señor (o de cualquier modo un sujeto) que actúa en los límites de un sistema ordenado, pero sin amenazar su regularidad."

123 'Es así excéntrico el estilo casual, el 'punk' revisado y corregido, el adorno extraño colocado en un traje tradicional, el uso de invertir los 'uniformes' tradicionalmente adecuados para determinadas ocasiones (utilizar los vaqueros para una cerimonia y el "smoking" para un paseo)."

${ }^{124}$ Em junho de 2013, ano em que o Brasil recebeu a Copa das Confederações, uma das sinalizações instaladas em Brasília para auxiliar os turistas ganhou diversas recriações. O motivo da repercussão foi um erro grotesco de tradução do português para o inglês, o que inspirou os usuários da rede a criarem suas próprias placas indicando outras localidades, baseadas em traduções literais e jogos de palavras.
} 
Figura 35 - Placa original instalada em Brasília.

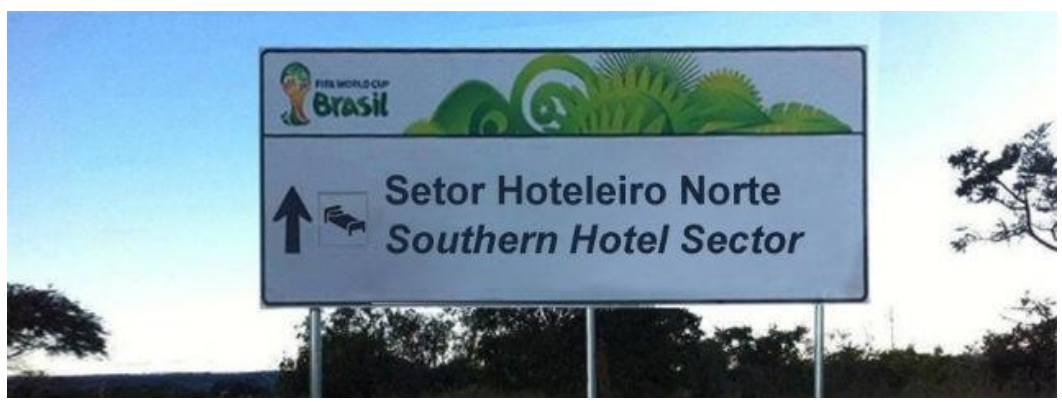

Fonte: www.youpix.com.br ${ }^{125}$

Figura 36 - Réplica do meme Placas da Copa.

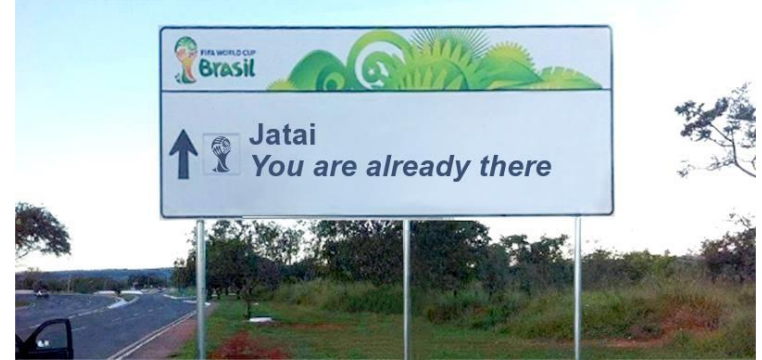

Fonte: www.facebook.com/PlacasDaCopa ${ }^{126}$

Figura 37 - Réplica do meme Placas da Copa.

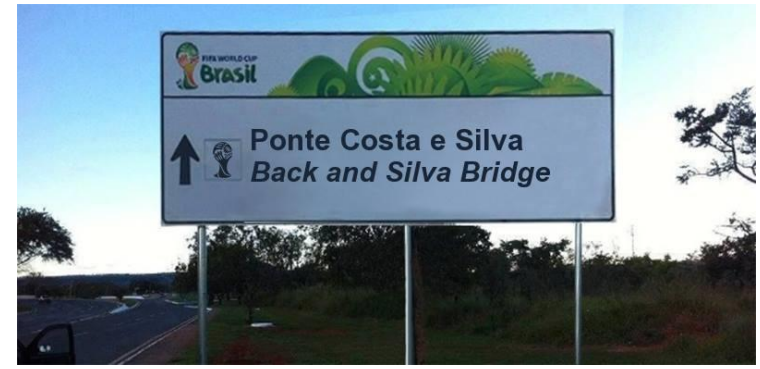

Fonte: www.facebook.com/PlacasDaCopa

Figura 38 - Réplica do meme Placas da Copa.

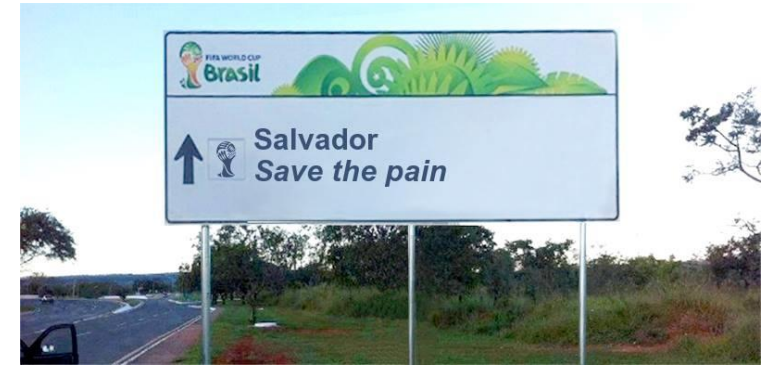

Fonte: www.facebook.com/PlacasDaCopa

\footnotetext{
125 <http://www.youpix.com.br/memepedia/meme-do-dia-placas-da-copa/> Acesso em 28/1/2014.

${ }^{126}$ Réplicas do meme Placas da Copa disponíveis em:

<https://www.facebook.com/PlacasDaCopa?ref=ts\&fref=ts> Acesso em 28/1/2014.
} 
Figura 39 - Réplica do meme Placas da Copa.

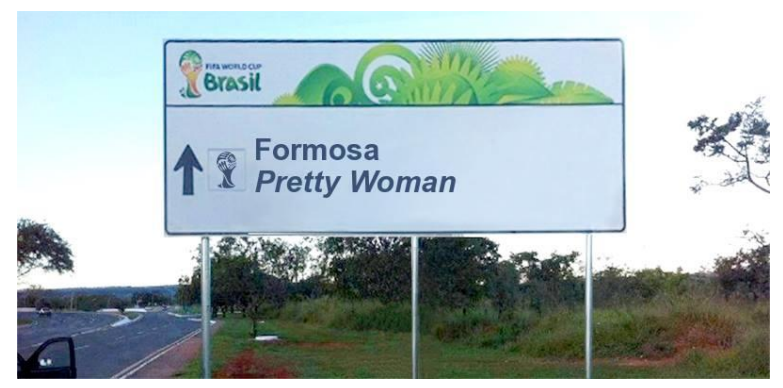

Fonte: www.facebook.com/PlacasDaCopa

Nesse caso, uma primeira paródia da placa motivou uma série de outras, fazendo da diferenciação (que nesse exemplo consistia em uma alternativa de tradução equivocada) uma norma para a configuração das réplicas desse meme. Assim, nos memes, uma primeira paródia pode motivar um conjunto de outras, convertendo a transgressão em "lei de funcionamento" do meme. O princípio paródico da linguagem do meme, assim, não os conforma enquanto uma simples imitação de um texto, tratando-se, na realidade, de uma confrontação textual que fixa a diferença no âmago da semelhança. Por não se tratar, portanto, de uma imitação pura e simplesmente, isto é, "um domínio monológico do discurso de outrem", a paródia define-se assim por seu dialogismo (HUTCHEON, 1986, p. 93): “um híbrido dialogístico intencional” no qual "linguagens e estilos iluminam-se ativa e mutuamente" (BAKHTIN, 1981, p. 76 apud HUTCHEON, 1986, p. 90). Posto isso, podemos tomar o processo paródico da linguagem do meme como apropriação e não imitação, porque essa apoderação dos textos os coloca em diálogo com outros textos e discursos.

A ideia de apropriação na paródia nos sugere, assim, um afrouxamento da individuação. Com relação à paródia na arte, Buchloh entende que ela e a apropriação estão ligadas a um desafio à perspectiva capitalista que vê a arte como individualidade e propriedade privada (BUCHLOH, 1982, p. 30 apud HUTCHEON, 1986, p. 136), nesse sentido, a paródia é uma contestação da ideia de propriedade. Sant'Anna é mais incisivo na sua análise, caracterizando a apropriação como dessacralização, um "desrespeito à obra do outro", ele entende o ato de parodiar como uma reificação, ou seja, "um modo de transformar a obra do outro em um simples objeto e material" para que o parodiador realize a sua obra (SANT'ANNA, 1988, p. 46).

No meme, essa noção de propriedade é, como na paródia, abrandada, e mais que isso, é posta em xeque, bem como a ideia de autoria. Afinal, o devir dos memes se funda no excesso de apropriações de uma informação (seguindo um modelo ou não), 
sendo considerado um meme uma gama de réplicas paródicas, no qual um elemento se repete. Nesse sentido, ainda que se possa, por vezes, atribuir historicamente um autor para a primeira réplica de um meme, esse artefato só ganha sentido ontológico se é fruto de uma criação coletiva, formada por inúmeros atos de invenção individual.

Tomada como categoria de análise, a paródia nos permite assim compreender o meme como um fenômeno comunicacional, a julgar por sempre investir o outro - o outro texto, a outra voz, o outro que reconhece as relações implicadas (o leitor), o outro que é co-criador - em uma relação dialógica. Esse diálogo, que se estabelece no contraste entre contextos textuais a partir de sua sobreposição, é marcado por certas tensões, que fazem do meme, considerado em seu princípio paródico, lei e transgressão, continuidade e ruptura, diferença na semelhança, incongruências que possibilitam emergir de suas réplicas um objeto risível (como veremos mais adiante). Essa leitura, contudo, exige certos conhecimentos prévios do leitor, que lhe permitem também reconhecer o meme (a paródia) enquanto tal, bem como aceitar participar do jogo de ressignificação proposto pela linguagem memética, jogo esse também aceito por quem produziu o meme - o jogo de linguagem.

Retomando aqui a metáfora dos jogos de linguagem de Wittgenstein, nos permitimos vislumbrar também um outro aspecto da ideia de jogo, além das regras, presente na linguagem do meme: o fato de possuir, enquanto um jogo, um caráter lúdico. Nesse sentido, pontuamos que o "seguir uma regra" para ressignificar algo em uma ocorrência memética é mais que um ato comunicativo, é também um ato lúdico de participação:

\begin{abstract}
$\mathrm{O}$ jogo consiste na necessidade de encontrar, de inventar imediatamente uma resposta que é livre dentro dos limites das regras. Essa liberdade de ação do jogador, essa margem concedida à ação, é essencial ao jogo e explica, em parte, o prazer que ele suscita. É igualmente ela que justifica utilizações tão notáveis e significativas da palavra "jogo" como as que se constatam nas expressões o jogo de um artista ou o jogo de uma engrenagem, para designar, num caso, o estilo pessoal de um intérprete, no outro, a falta de afinação de um mecanismo. (CALLOIS, 1990, p. 27-28, grifo do autor)
\end{abstract}

Acrescentando aqui então um elemento à metáfora de Wittgenstein: o funcionamento da linguagem do meme, assim, por ser entendido como um jogo, tem também um caráter de entretenimento, que está em partes nessa liberdade dos falantes de ao se expressar estarem também criando e se divertindo, nos limites colocados pelas regras. Uma das regras do meme, isto é, uma de suas generalidades, é a paródia, que ao construir uma relação intertextual (intercontextual) acaba criando um tensão, podendo tirar o texto parodiado de sua normalidade. Nesse sentido, o meme parece estar sempre 
trabalhando no limite de algo já estabelecido, muitas vezes rompendo esse limite na possibilidade da experimentação do excesso, uma categoria secundária que veremos a seguir em conjunção com a noção de exagero.

\subsection{0 excesso e o exagero}

A ideia de excesso no meme, como exposto anteriormente, pode articular-se com a repetição. Como vimos, cada ocorrência memética é um processo de reiteração excessiva e, nesse sentido, podemos dizer que há uma forma de exagero que está no próprio devir dos memes, uma linguagem que se ampara no excesso e em certo descontrole da produção de textos. Essa produção excessiva talvez se dê pela própria dinâmica da comunicação na internet, em que o polo de emissão é menos concentrado que em meios como a televisão, por exemplo, nos quais prevalece o domínio de algumas instituições que produzem e veiculam as mensagens. Não intencionamos, contudo, cair na ilusão de que a internet é um ambiente democrático, pois seria ingênuo afirmar que há na rede uma democratização da comunicação no sentido político, uma vez que nem todos os grupos sociais possuem voz e que a presença de gatekeepers e das hierarquias ainda são fortes (MILNER, 2012, p. 2), sem contar ainda com as questões de democratização de acesso, anteriores a tudo isso. Assim, o ponto que queremos ressalvar na comparação com outros meios é que há de se reconhecer que, na internet, o polo de emissão é pulverizado, divido em uma quantidade muito maior de possíveis emissores e, com uma quantidade maior de produtores de conteúdo e que conseguem dar vazão a suas produções no meio, o volume de réplicas e o seu espalhamento se tornam facilitados.

Podemos pensar também, nesse sentido, que esse acesso facilitado aos meios de produção cultural e de difusão também possuem uma consequência de ordem estética. A paródia expressa em imagens, vídeos, tirinhas, entre outros, é feita, em sua maioria, por amadores ou semiprofissionais (FONTANELLA, 2009a, p. 5-6), voltada para o uso prazeroso das mídias digitais a partir de sua apropriação tática, não há uma preocupação com padrões de qualidade técnica ou estética (FONTANELLA, 2011, p. 3), sendo, por muitas vezes, produzidos até mesmo de maneira intencionalmente descuidada. Poderíamos pensar assim que certa facilidade para a produção, bem como a não preocupação estética, produziriam essas paródias que deixam a marca de sua gênese. Essa dita facilidade e a pulverização dos produtores e emissores aliadas a certa 
motivação em "participar do jogo" nos permitem, assim, vislumbrar uma explicação para o excesso nas dinâmicas de circulação e replicação dos memes, que está não só na quantidade de réplicas, mas também na velocidade com que essas produções se alastram, dando ao meme um caráter de instantaneidade.

Além dessa manifestação do excesso, ele também aparece no meme de forma qualitativa, como exagero, na própria construção de sentido das réplicas dos memes. A princípio, essa exageração pode ser pensada a partir da hipérbole, uma figura de linguagem definida na retórica como uma expressão desproporcional de um objeto, com o objetivo de "levar ao extremo o significado que o discurso objetiva de forma qualitativa ou quantitativa" (PINHEIRO, 2013, p. 150), ou seja, a hipérbole consiste em uma ênfase, é uma figura que altera a intensidade do que está sendo exprimido, seja para mais ou para menos. Entendida essa figura assim, podemos tomar como exemplo de exageração de sentido o meme Ridiculously Photogenic Guy (Cara Ridiculamente Fotogênico), baseado na fotografia do sorridente Zeddie Little, enquanto participava de uma corrida, a Cooper River Bridge Run de 2012 em Charleston, Carolina do Sul, nos Estados Unidos. A imagem (Figura 40) ganhou notoriedade no fórum Reddit, tornandose um meme em seguida, a partir de montagens e da emergência de uma série de fotolegendas (Figura 41). Ilustramos aqui justamente as fotolegendas, nas quais os discursos remontam situações que hiperbolizam a beleza do jovem Zeddie Little.

Figura 40 - Zeddie Little na corrida.

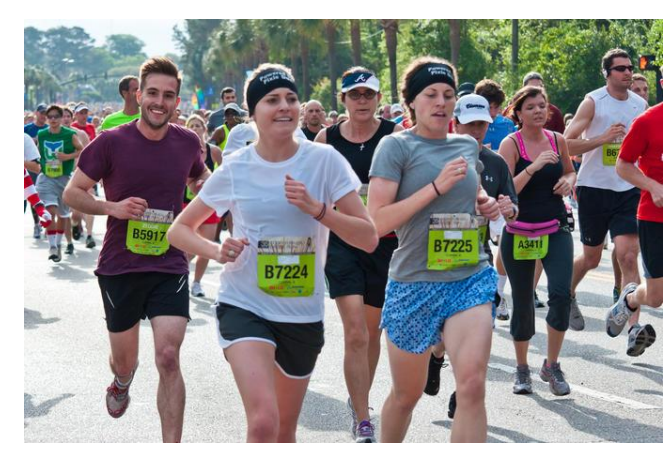

Fonte: knowyourmeme.com ${ }^{127}$

$\overline{127}$ < http://knowyourmeme.com/memes/ridiculously-photogenic-guy-zeddie-little> Acesso em 19/8/2014. 
Figura 41 - Réplicas do meme Ridiculously Photogenic Guy.

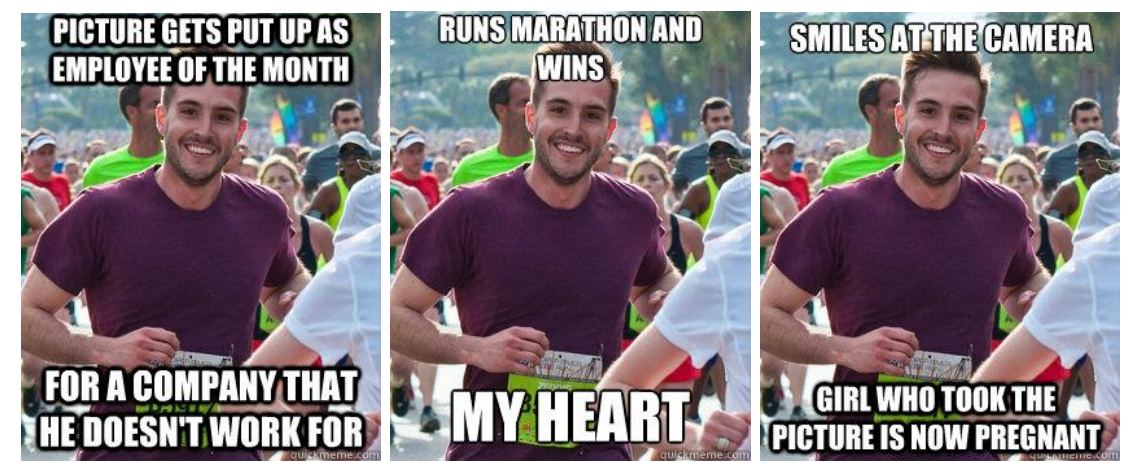

Fonte: knowyourmeme.com ${ }^{128}$

Réplica 1: "Sua foto aparece no quadro de funcionários do mês para uma companhia que ele não trabalha". Réplica 2: "Corre uma maratona e ganha meu coração". Réplica 3: Sorri para a câmera, a garota que tirou a foto agora está grávida"

$\mathrm{Na}$ hipérbole, portanto, o exagero parte de uma premissa ("Zeddie Little é bonito") que é então intensificada, excedendo os limites da verossimilhança. Remontando, assim, a etimologia da palavra de origem grega hipérbole, cujo prefixo "hiper" significa "por cima de" e "bole" significa "lançar", temos como significado do termo "lançar por cima de" ou "para lá de" ${ }^{129}$. Partindo dessa acepção inicial, podemos entender, portanto, que o aumento da intensidade que se dá pela hiperbolização consiste na extrapolação de algum limite ("para lá de"), sejam esses limites as proporções físicas, o bom senso, o que é verossímil ou qualquer outro que convencionamos na nossa apreensão do mundo. O mesmo pode ser percebido na hipérbole visual do meme Meet and Greet de Avril Lavigne. A cantora canadense esteve no Brasil em 2014 e deu a oportunidade aos fãs de conhecê-la e tirarem fotos com ela no camarim, mediante o pagamento de uma alta quantia em dinheiro. Para tanto, os fãs foram instruídos a não encostarem em Avril, o que acabou resultando em fotografias constrangedoras (Figura 42), que acabaram servindo de base para uma série de paródias, nas quais o distanciamento é exagerado (Figuras 43 a 46).

\footnotetext{
128 < http://knowyourmeme.com/memes/ridiculously-photogenic-guy-zeddie-little> Acesso em 19/8/2014.

${ }^{129}$ Referência: < http://definiciona.com/hiperbole/> Acesso em 19/8/2014.
} 
Figura 42 - Fotografias de Avril Lavigne com os fãs.

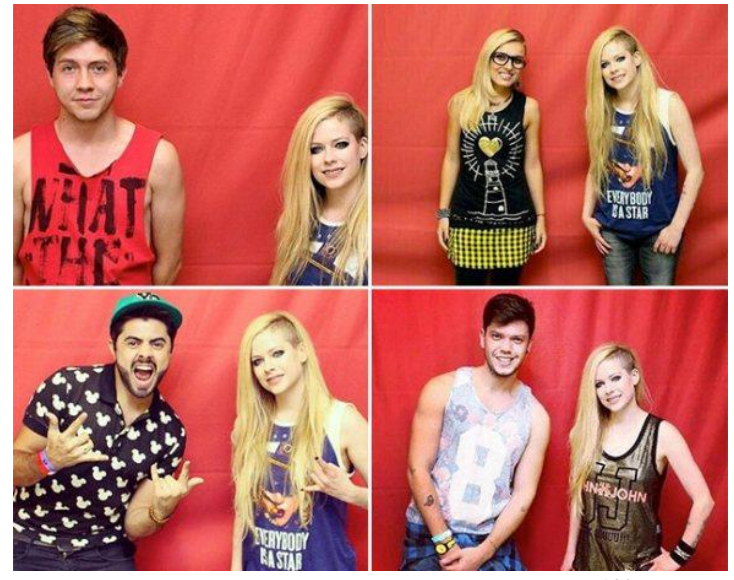

Fonte: lobobarbudo.wordpress.com ${ }^{130}$

Figura 43 - Réplica do meme Meet and greet de Avril Lavigne.

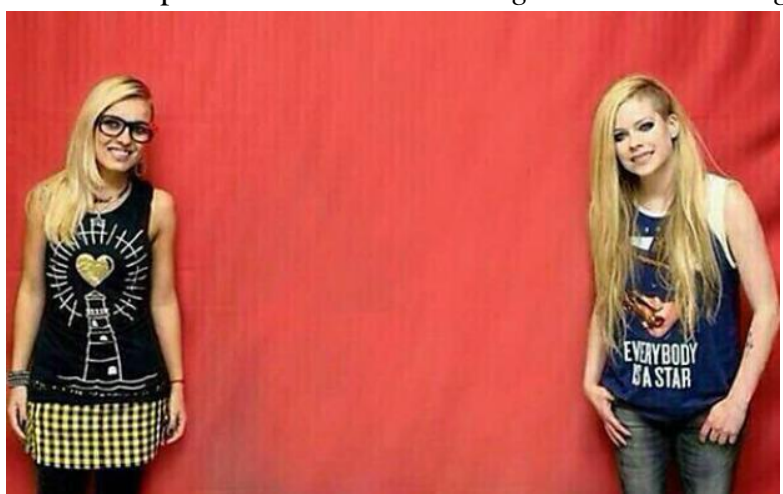

Fonte: mixme.com.br ${ }^{131}$

Figura 44- Réplica do meme Meet and greet de Avril Lavigne.

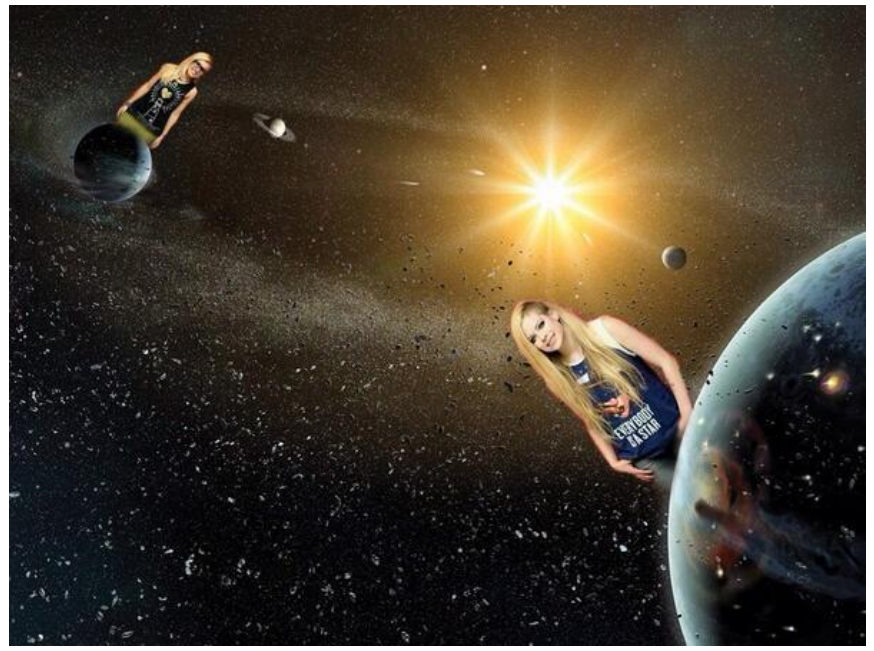

Fonte: mixme.com.br ${ }^{132}$

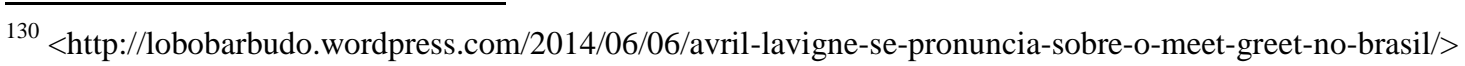
Acesso em 28/10/2014

${ }^{131}<$ http://mixme.com.br/novidades/confira-os-menes-mais-engracados-do-meet-great-da-avril-lavigne-nobrasil/> Acesso em 28/10/2014. 
Figura 45 - Réplica do meme Meet and greet de Avril Lavigne.

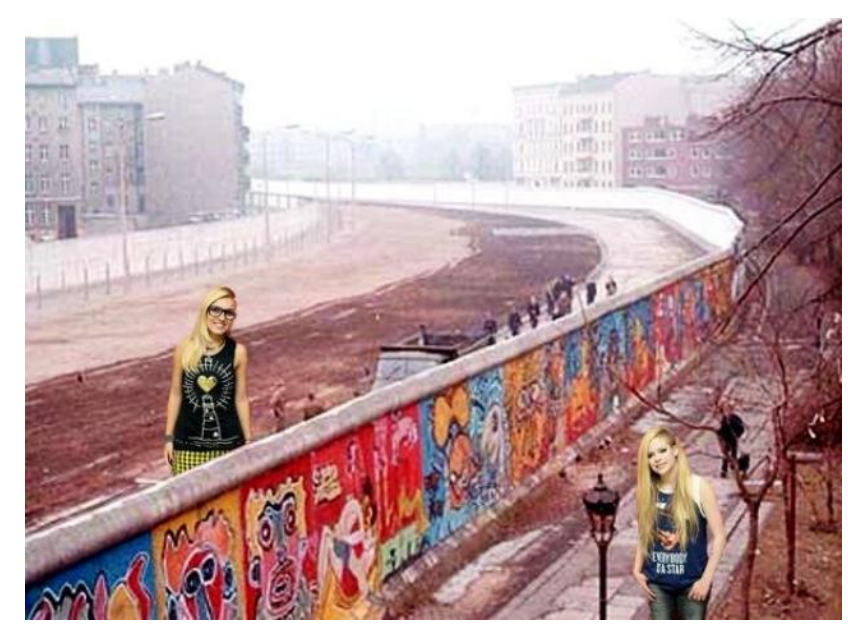

Fonte: br.celebridades.yahoo.com ${ }^{133}$

Figura 46 - Réplica do meme Meet and greet de Avril Lavigne.

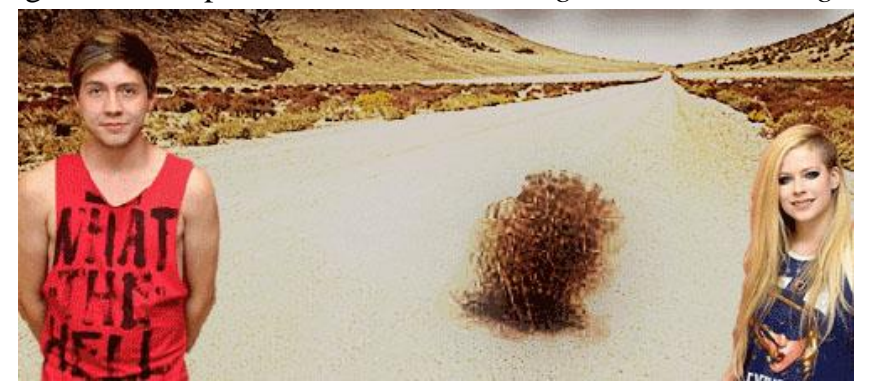

Fonte: evilregalhooker.tumblr.com ${ }^{134}$

O excesso, assim, tachado em qualquer sociedade ou sistema como aquilo que não se pode nem se deseja absorver (CALABRESE, 1999, p. 75) é, no meme, endógeno ao seu sistema cultural, aparecendo tanto na conformação de sua repetição como na produção de sentidos dos textos, provocando outras concepções da realidade. Desse modo, buscamos aqui ampliar o entendimento da hipérbole, compreendendo-a também no sentido de uma ruptura de fronteiras: para tornar a significação de algo mais intensa se faz presente o descomedido, o desregrado, algo que transgrida alguma espécie de limite, algo que seja excessivo de alguma maneira.

A articulação da repetição, da paródia, do excesso, do exagero podem, assim, "dilatar" um objeto, o fazer transbordar, sair de sua delimitação, ser visto de outro ângulo, romper uma lógica precedente. Dessas relações que unem o que é heterogêneo,

\footnotetext{
${ }^{132}<$ http://mixme.com.br/novidades/confira-os-menes-mais-engracados-do-meet-great-da-avril-lavigne-nobrasil/> Acesso em 28/10/2014.

$133<$ https://br.celebridades.yahoo.com/blogs/nina-lemos/meet-greet-n\%C3\%A3o-era-mais-vantagem-tirar-foto155905895.html> Acesso em 28/10/2014.

${ }^{134}$ < https://www.tumblr.com/search/avril\%20lavigne\%20meet\%20and\%20greet> Acesso em 28/10/2014.
} 
que podem originar algo insólito e que intensificam algo que já é fantástico por si só, pode emergir, como mencionamos anteriormente, algo cômico. Nesse sentido, podemos afirmar que a cultura do meme, por meio da linguagem, também oportuniza uma concepção risível da realidade.

\subsection{A carnavalização e a concepção cômica do mundo}

O cômico entra na análise de nosso objeto como uma categoria secundária, uma vez que é realizável e articulável a partir da tensão criada na repetição paródica. Pelo meme, vimos que é possível perturbar uma ordem estabelecida "violando" a configuração das representações. Essa forma dada, inicial, de representar a realidade que é transgredida não é totalmente apagada na nova representação: ela permanece pressuposta. Residiria nesse aspecto do meme uma abertura para o seu caráter risível, se aceitarmos que "rimos da incongruência entre as duas formas de representação pelas quais apreendemos o mundo" (SCHOPENHAUER apud ALBERTI, 2002, p. 172), uma forma séria, dentro da normalidade ou simplesmente uma forma que estamos tomando como ponto de partida e uma outra forma que lhe é alheia. Em algumas ocorrências meméticas, mais do que pressuposta, essa incongruência (ou heterogeneidade) está manifesta e aparente, na própria representação. Temos em algumas delas simultaneamente a representação de determinado objeto (uma fotografia, um vídeo, uma imagem, uma informação) e também a sua porção destoante. A possibilidade do riso estaria assim nesse reestabelecimento do que já está estabelecido, nas novas associações, na união do que é heterogêneo, no exagero, entre outras articulações possíveis.

Como exposto, esse elemento risível que estamos atribuindo aos memes pode aparecer como efeito de um entendimento, dependendo de um contexto cultural de recepção que envolve memória (conhecimentos prévios), temporalidade e uma compreensão respondente por parte de quem recebe esses textos. As ocorrências meméticas podem ou não ter graça, dependendo desses fatores, da semiosfera enquanto contexto cultural, que sustenta a leitura desses textos de determinada forma e não outra. Reconhecido isso, permitimo-nos aqui localizar a comicidade não apenas na perspectiva da recepção, mas também vislumbrá-la pelo ponto de vista do criador, aquele que busca construir um sentido. Desse modo, discutiremos a possibilidade risível do meme, sugerindo também que a comicidade opere como um "método de ressignificação", isto 
é, uma maneira de apreender a realidade que permite aos "falantes" da linguagem-meme atualizar a potencialidade sígnica de um meme por meio de associações antes impensadas. Para tanto, partiremos da ideia de carnavalização de Mikhail Bakhtin.

O conceito de carnavalização, proposto pelo pensador russo, chave para a compreensão do grotesco enquanto categoria estética, dá continuidade assim à nossa análise na compreensão do jogo memético de significação. O que nos mostra o carnaval, e por isso a relação dele com a nossa proposta de entendimento, é o fato de ele conformar um modo diferente de "acessar o real", de estar nesse mundo, de entender esse mundo, isto é, revela uma concepção cômica da realidade.

Voltemo-nos, então, à praça pública medieval e aos festejos do carnaval, celebrações que proporcionavam outra visão do mundo e relações humanas totalmente diferentes do que era vivido o ano inteiro, criando um ambiente propício para tudo que era não-oficial. Bakhtin, ao apresentar essa ambiência, nos mostra que o carnaval configurava uma segunda vida, experimentada ocasionalmente pelos homens e mulheres da Idade Média. No carnaval, ocorria, portanto, uma fuga provisória da vida oficial, o povo era arrancado da ordem e liberto das normas de etiqueta e decência. A segunda vida, de que nos fala Bakhtin (1987, p. 4-10), consiste assim em um "mundo ao revés", em certa medida, essa mundo é construído pela cultura popular como paródia da vida cotidiana. "O homem medieval imita, copia deformando" (MINOIS, 2003, p. 155).

Os festejos eram também um momento de afrouxamento das hierarquias e abolição das distâncias entre os indivíduos, propiciando a emergência de uma linguagem carnavalesca, com seu próprio vocabulário e gestos, constituindo uma forma particular de comunicação impossível de ser imaginada em outro tipo de situação de interação social. Era por meio desta linguagem carnavalesca que se manifestava a percepção carnavalesca do mundo, uma visão "oposta a toda ideia de acabamento e perfeição, a toda pretensão de imutabilidade e eternidade, necessitava manifestar-se através de formas de expressão dinâmicas e mutáveis (proteicas), flutuantes e ativas" (BAKHTIN, 1987, p. 9). Assim, graças às noções de abertura e inacabamento, materializada em uma linguagem cômica, oposta à seriedade, era possível relativizar as verdades das autoridades no poder (Estado e Igreja, os moldes oficiais).

Nesse sentido, o riso carnavalesco, como nos mostra Bakhtin, caracteriza-se por sua popularidade, universalismo e ambivalência. Ele é popular, porque é geral, "todos riem", o aspecto popular é intrínseco à natureza do carnaval. Esse riso é também universal, pois atinge a tudo e a todos, inclusive os que participam do carnaval, dessa 
forma, "o mundo inteiro parece cômico e é percebido e considerado no seu aspecto jocoso, no seu alegre relativismo". E, por fim, é ambivalente, cheio de dualidades: ao mesmo tempo em que é alegre, é sarcástico, pode afirmar e negar, "amortalha e ressuscita simultaneamente" (ibidem, p. 10). Dessa maneira, os festejos da cultura popular culminavam em uma concepção cômica do mundo, um mundo que era visto como imperfeito, inacabado, dinâmico e em constante transformação, um mundo que só era possível se visto pelas lentes do riso, seja ele alegre ou zombador.

Paralelo às festas, como parte desse modo de conceber, havia também as mais variadas formas e gêneros do vocabulário familiar e grosseiro, além das obras verbais. No ambiente da praça pública, onde reinava a abolição provisória das regras e tabus do dia a dia, o ambiente tornava-se propício para a configuração de uma outra maneira de se comunicar, com gêneros inéditos, mudanças de sentido, eliminação de formas em desuso. Assim, com as distâncias da comunicação formal encurtadas entre as pessoas, faziam-se presentes, por exemplo, a linguagem informal, expressões inconvenientes e grosserias $^{135}$, que também era dirigidas às divindades (ibidem, p. 14 e 15).

A visão cômica do mundo também se traduzia nas obras literárias de festa, que permitiam o povo zombar e revirar as condições sociais e nas quais os ritos sagrados eram parodicamente reelaborados, como nas "liturgias, preces e sermões bufos, paródias de romance de cavalaria, fábulas e farsas, peças religiosas, com diabruras" (MINOIS, 2003, p. 157). Dessa forma, o conteúdo oficial, produzido nos discursos e rituais da igreja, era apropriado para ser reinventado de maneira risível, sempre marcada por uma linguagem verbal igualmente carnavalesca, alegre e despretensiosa em relação às formalidades de uma etiqueta.

Com o seu recorte, a partir do olhar depositado nos festejos e na literatura e vocabulário que tomam forma nesses eventos, Bakhtin procura evidenciar como a cultura cômica popular servia de pano de fundo para a produção artística, em especial na obra de Rabelais. Para Bakhtin, assim, a "carnavalização" seria a transposição da linguagem do carnaval a outras linguagens, isto é, a incorporação das categorias carnavalescas: o "mundo ao avesso", a "vida ao contrário", a abolição da ordem hierárquica, a mistura de valores, fenômenos, pensamentos e coisas, a profanação

\footnotetext{
135 “Do ponto de vista gramatical e semântico, as grosserias estão normalmente isoladas no contexto da linguagem e são consideradas como fórmulas fixas do mesmo tipo dos provérbios. Portanto, pode-se afirmar que as grosserias são um gênero verbal particular da linguagem familiar. Pela sua origem, elas não são homogêneas e tiveram diversas funções na comunicação primitiva, essencialmente de caráter mágico e encantatório" (BAKHTIN, 1987, p. 15).
} 
(PONZIO, 2011, p. 172). Desse modo, a falta de censura, a quebra da decência e o exagero e a partilha da intimidade na praça pública aparecem na literatura, no teatro e nas artes plásticas como o princípio da vida material e corporal. As imagens referentes a essa gênese, tanto em Rabelais, como nos demais autores do Renascimento, é, portanto, uma herança um pouco modificada da cultura cômica popular e da concepção estética da vida prática dessa cultura, se caracterizando por imagens hiperbólicas do corpo, relacionadas ao comer, ao beber, à satisfação de necessidades naturais e da vida sexual (BAKHTIN, 1987, p. 16-17). A essa concepção foi dado o nome de grotesco, que podemos entender de maneira mais ampla como uma estética que se define pelo rebaixamento manejado por combinações inusitadas, insólitas, de elementos heterogêneos, apresentando situações absurdas, mudanças de sentido, animalidade, figuras relacionadas com as partes baixas do corpo, escatologia, sendo reconhecida assim como um conjunto de fenômenos em desarmonia com o gosto. Suas atualizações históricas nas mais diversas épocas vêm produzindo um padrão de reação, caracterizada pelo riso, horror, espanto, repulsa (SODRÉ e PAIVA, 2002, p. 17).

Dada essa descrição geral dos festejos, celebrações e produções textuais, o que sugere então o carnaval em relação ao nosso objeto? Um de nossos primeiros incômodos, no sentido positivo e instigador do termo, com relação aos memes, era o fato de que, aparentemente, qualquer informação teria potencial para ter o seu sentido deslocado e em seguida ser passível da extensa replicação tão característica desse fenômeno. A partir do carnaval, podemos agora ampliar nossa compreensão sobre essa reconfiguração sígnica. Ao tomar uma imagem, vídeo, frase que se torna meme, podemos dizer que há algo nesses objetos, ou melhor, na relação entre quem cria o meme e esses objetos que permite a ressignificação. O elemento transformador presente nessa relação seria um olhar do cômico sobre o objeto. Isto é, o riso enquanto provocador de novas concatenações. Podemos pensar, a partir de Bakhtin, que o devir das ocorrências meméticas é uma carnavalização das informações que chegam aos que dominam essa linguagem.

Bakhtin, quando nos apresenta o carnaval da praça pública, nos mostra um mundo ao revés, uma época em que havia uma interrupção provisória de todo sistema oficial, um momento em que "a vida saía de seus trilhos habituais, legalizados e consagrados e penetrava no domínio da liberdade utópica" (BAKHTIN, 1987, p. 77). A cosmovisão carnavalesca trazida para o contexto cultural do meme nos permite entender, portanto, o deslocamento de sentido, esse "sair dos trilhos habituais" que é 
propiciado pela concepção cômica, articulada na paródia e na repetição e em seus tensionamentos.

Uma modelo que posa em cenários desastrosos, insólitos ou totalmente não condizentes com o mundo físico em que vivemos ${ }^{136}$ (Figura 47); um gato com ar de sofisticação ${ }^{137}$ que manifesta seus desejos ao tomar seu café da manhã (Figura 48 e 49); grupos de pessoas que fazem uma dança excêntrica nos mais variados cenários ${ }^{138}$ (Figura 50). Ou seja, o riso, que no carnaval libertava o homem da censura (tanto exterior como interior), abrindo os olhos para algo novo, para o futuro (ibidem, p. 81) nos permite reestabelecer o que já está estabelecido, também libertar-nos, criar novas associações, unir o que é heterogêneo, trazer o absurdo para o cotidiano (ou realçar um absurdo que já se insere nele). Assim como no carnaval, são maneiras provisórias de conceber, tem sentido em um contexto, em determinada circunstância. Além disso, esses novos sentidos se iluminam no contraste de algo já conhecido e na sua transgressão, como explorado na abordagem do aspecto parodístico do meme, de modo que "o reconhecimento do mundo invertido exige [...] um conhecimento da ordem do mundo que inverte e, em certo sentido, incorpora" (HUTCHEON, 1985, p. 95).

\footnotetext{
${ }^{136}$ Em outubro de 2012, época em que ocorreu o furacão Sandy nos Estados Unidos, a modelo brasileira Nana Gouvêa decidiu posar para fotografias em meio aos danos causados pelo desastre natural. Algumas horas após a divulgação das imagens no portal de notícias Ego, os internautas responderam à atitude de Nana ridicularizando a situação por meio de diversas montagens da modelo em eventos trágicos da história mundial e outas situações consideradas desastrosas. A partir da apropriação e ressignificação e de uma posterior multiplicação desenfreada dessas imagens, surgiu o meme Nana Gouvêa em Desastres.

${ }^{137}$ O meme I Should Buy a Boat Cat, também conhecido como Sophisticated Cat e Fancy Cat, apresenta uma série de fotolegendas de um gato usando um terno, com frases que descrevem suas epifanias e desejos. A imagem foi retirada de um trecho do clipe da cantora Bjork e posteriormente legendada e compartilhada no fórum Reddit, ganhando diversas recriações a partir da alteração da legenda.

138 "Harlem Shake" é o nome da música criada pelo DJ Baauer (Harry Rodrigues), que acabou gerando uma série de vídeos que geralmente começam com um indivíduo mascarado dançando sozinho diante de um grupo de pessoas. Depois de um corte repentino nas imagens, todos do grupo começam a dançar freneticamente. Fonte: < http://knowyourmeme.com/memes/harlem-shake> Acesso em 14/1/2014.
} 
Figura 47 - Réplicas do meme Nana Gouvêa em Desastres.

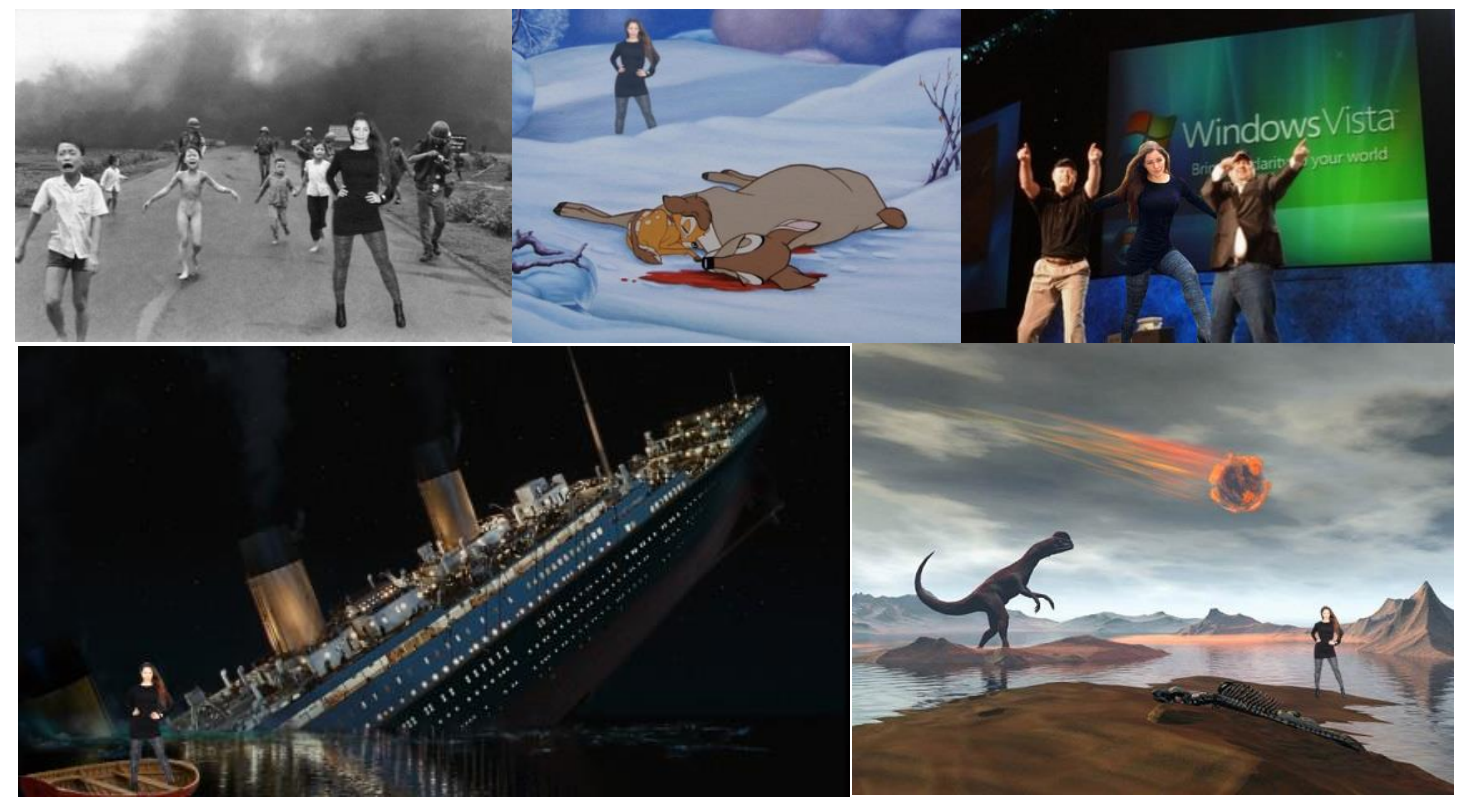

Fonte: nanagouveaemdesastres.tumblr.com ${ }^{139}$

Figura 48 - Réplica do meme Sophisticated Cat.

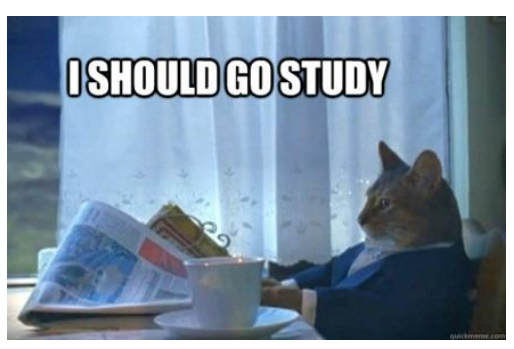

Fonte: www.quickmeme.com ${ }^{140}$

"Eu deveria ir estudar".

Figura 49 - Réplicas do meme Sophisticated Cat.
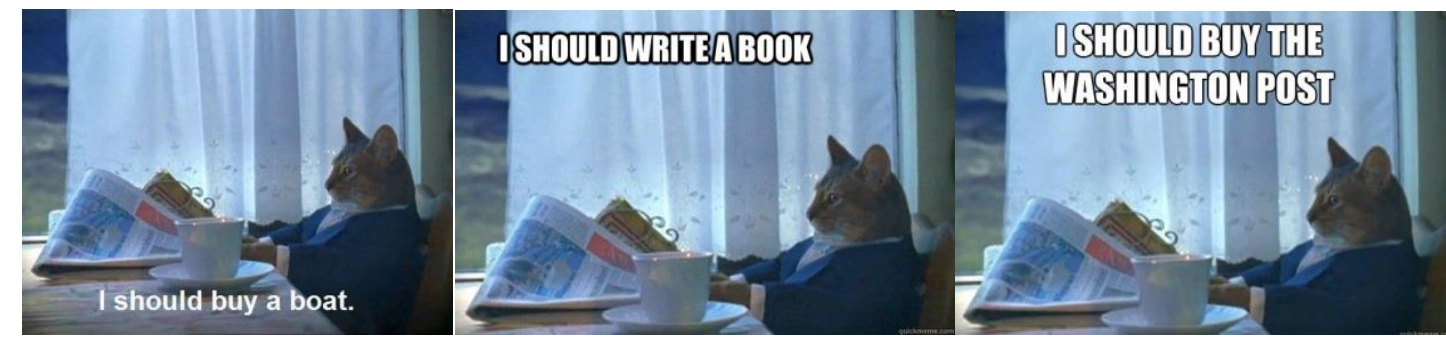

Fonte: knowyourmeme.com ${ }^{141}$

Réplica 1: "Eu deveria comprar um barco". Réplica 2: "Eu deveria escrever um livro". Réplica 3:

Eu deveria comprar The Washington Post".

\footnotetext{
$139<$ http://nanagouveaemdesastres.tumblr.com/> Acesso em 28/1/2014.

$140<\mathrm{http}: / /$ www.quickmeme.com/meme/3s64qs> Acesso em 5/8/2014

${ }^{141}<$ http://knowyourmeme.com/memes/i-should-buy-a-boat-cat $>$
} 
Figura 50 - Printscreens das réplicas do meme Harlem Shake.
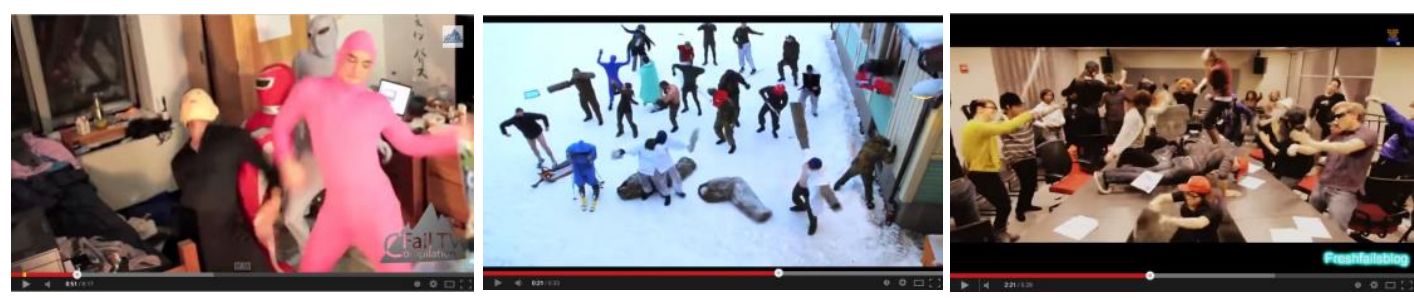

Fonte: youtube.com ${ }^{142}$

Essa postura grotesca de abertura ao possível diante das representações do mundo (seja da Igreja, do Estado ou do que concebemos a respeito de qualquer objeto de um signo) decorre da concepção carnavalesca do mundo:

$\mathrm{O}$ riso e a visão carnavalesca do mundo, que estão na base do grotesco, destroem a seriedade unilateral e as pretensões de significação incondicional e intemporal e liberam a consciência, o pensamento e a imaginação humana, que ficam assim disponíveis para o desenvolvimento de novas possibilidades. Daí que uma certa "carnavalização" da consciência precede e prepara sempre as grandes transformações, mesmo no domínio científico. (BAKHTIN, 1987, p. 43)

Mesmo nas formas do riso atenuado (humor, sarcasmo, ironia), como Bakhtin caracteriza o riso carnavalesco no Romantismo, podemos sentir uma "alegria especial 'licenciosa' do pensamento e da imaginação" (idem). E essa alegria está justamente na mudança, nas transformações, pois no mundo grotesco a relatividade de tudo que há é alegre.

Supomos, assim, que a carnavalização como uma maneira cômica de ver o mundo pode ser entendida com relação a um modo abdutivo de apreensão desse mundo, fazendo aqui uma associação com o que propõe Peirce ao pensar o método científico (ou mesmo as atividades humanas ordinárias). Podemos talvez, desse modo, vislumbrar a ideia de que a visão carnavalesca nos "predispõe" ao pensamento abdutivo, uma vez que, como nos mostra Bakhtin, libera "a consciência, o pensamento e a imaginação humana, que ficam assim disponíveis para o desenvolvimento de novas possibilidades" (idem). A visão carnavalesca se insere, assim, dentro de uma lógica da surpresa, surpresa essa que nasce da ruptura de um hábito, da quebra de uma expectativa (NUBIOLA, 2001), pois trata-se de um olhar para um mundo aberto, incompleto, possível, que pode nos surpreender. E a apreensão desse mundo, o entendimento dessa

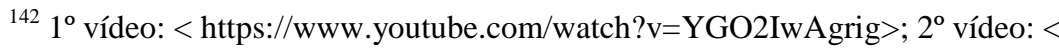
https://www.youtube.com/watch? $\mathrm{v}=4 \mathrm{hpEnLtqUDg}>$; $3^{\circ}$ vídeo: <https://www.youtube.com/watch?v=8f7wj_RcqYk > Acesso em 2/9/2014.
} 
surpresa se torna possível pela abdução, pela criatividade, que consiste na maneira que o indivíduo relaciona os elementos dispostos em sua experiência, na forma de um insight: "é a ideia de relacionar o que nunca antes havíamos sonhado relacionar o que ilumina de repente a nova sugestão ante nossa contemplação ${ }^{143 ”}$ (PEIRCE, CP 5.181 apud NUBIOLA, 2001). O riso seria, assim, o espaço de "redenção do pensamento". Entendido em uma oposição ao sério, ele se configura no espaço do indizível, do impensado, sendo "necessário para que o pensamento sério se desprenda dos seus limites" (ALBERTI, 2002, p. 11).

A partir dessa reflexão, podemos pensar o riso carnavalesco como uma força criadora. É o olhar desvelado de seriedade que permite a ressignificação (reinterpretação) das informações que se tornam memes. A cosmovisão carnavalesca, portanto, motiva uma reconfiguração do mundo que apreendemos, é o que torna possível a atualização de uma potencialidade inserida no signo. É curioso observar no meme, no entanto, que, ao mesmo tempo em que esse entendimento do mundo provoca uma ruptura do que estamos convencionalmente acostumados, que mescla elementos paradoxais, que traz o inusitado, que tira as formas de agir e representar dos trilhos, torna-se também algo que se convenciona, por meio da repetição. Temos um desvio inicial que se torna norma, que se repete no meme, sem perder de vista sua concepção risível de mundo, porque, ainda que se convencione, há em todas as réplicas de um meme um elemento desse desvio inicial, continua se configurando, assim, como uma incongruência com relação a outras formas de entender o mundo.

Nesse mundo ao revés, intensificado, exagerado e às vezes distorcido, visto pela perspectiva carnavalesca, possibilitado por uma mediação da paródia, também se insere o absurdo, nossa próxima categoria a ser explorada. Para essa discussão, partiremos do surrealismo, que tem sua origem no grotesco romântico, movimento que também nos servirá de base para a compreensão de um tipo especial de riso, o humor, que veremos adiante.

\subsection{O absurdo}

O adjetivo absurdo qualifica aquilo que é repugnante à razão, diz-se do que não tem sentido, do que é disparatado, que vai de encontro ao bom senso, o que rompe com

\footnotetext{
143 "[...] es la idea de relacionar lo que nunca antes habíamos soñado relacionar lo que ilumina de repente la nueva sugerencia ante nuestra contemplación" (CP 5.181, 1903)
} 
a lucidez. Para articular essas noções ao nosso objeto, aproximaremos o entendimento do absurdo ao que é proposto pelo surrealismo. Para tanto, nos fundamentamos em uma manifestação do grotesco que se difere do realismo grotesco da Idade Média e do Renascimento, foco da análise de Bakhtin. Nosso ponto de partida é o romantismo grotesco (ou grotesco romântico), cujas tradições foram retomadas, em diferentes graus, no século XXI, originando o grotesco modernista, que entre suas manifestações estão o surrealismo e o expressionismo (BAKHTIN, 1987, p. 40).

O grotesco romântico, diferente do realismo grotesco da Idade Média e do Renascimento que expressa uma visão de mundo popular e carnavalesca, passa a conceber a realidade em uma perspectiva subjetiva e individual, não obstante ainda conserve alguns elementos das manifestações grotescas das épocas precedentes (ibidem, p.32). Bakhtin refere-se a essa tradição como "grotesco de câmara", isto é, uma manifestação dessa categoria estética em que a sensação carnavalesca do mundo, que antes era inclusive corporalmente vivida, transfere-se para "a linguagem do pensamento filosófico idealista e subjetivo" (ibidem, p. 33).

O universo grotesco, nessa tradição, é terrível e alheio ao homem. No romantismo tudo que é cotidiano, corriqueiro, banal, "reconhecido por todos" passa de súbito a ser hostil, insensato, duvidoso, estranho ao homem, e a reconciliação com esse mundo, por vezes terrível, quando acontece, se dá em um plano subjetivo, lírico ou até mesmo místico. Nesse cenário, as imagens da vida corporal e material perdem seu caráter regenerador, tornando-se "vida inferior" (ibidem, p. 34). No entanto, apesar desse aspecto regenerador ter se enfraquecido, o grotesco romântico não deixa de configurar um entendimento de mundo de ruptura com o que já está conformado:

\footnotetext{
Na realidade, o grotesco, inclusive o romântico, oferece a possibilidade de um mundo totalmente diferente, de uma ordem mundial distinta, de uma outra estrutura da vida. Franqueia os limites da unidade, da indiscutibilidade, da imobilidade fictícias (enganosas) do mundo existente. O grotesco, nascido da cultura cômica popular, tende sempre, de uma forma ou de outra, a retornar ao país da idade de ouro de Saturno, e contém a possibilidade viva desse retorno." (BAKHTIN, 1987, p. 42)
}

A "idade de ouro" de que fala Bakhtin corresponde na mitologia greco-romana ao governo de Saturno (Cronos, para os gregos), um período marcado pela justiça e equidade, no qual todos eram felizes e iguais entre si. As festas saturnais, possível origem do carnaval, celebravam um retorno mítico a essa era de igualdade, abundância e felicidade. A alegria proporcionada por essa volta periódica aos tempos do reinado de 
Saturno manifestava-se justamente pelo riso, que tirava o indivíduo de seu ambiente cotidiano, rompia regras e ultrapassava os limites (MINOIS, 2003, p. 97 e 99).

Nesse sentido, o princípio da carnavalização também se faz presente mesmo no grotesco romântico, no qual a possibilidade de retorno à "idade de ouro" se dá por meio das formas subjetivas características dessa tradição do grotesco: "O homem encontra-se consigo mesmo e o mundo existente é destruído para renascer-se e renovar-se em seguida" (BAKHTIN, 1987, p. 42). Há de se ressaltar ainda que o riso, que está na essência do carnaval, não desaparece no grotesco romântico, apenas se abranda, tornando-se humor, ironia e sarcasmo, tidos por Bakhtin como formas reduzidas do riso (ibidem, p. 33).

Em síntese, essa é a configuração do grotesco romântico, do qual o surrealismo, parte do grotesco modernista, retomou a valorização da interioridade (subjetividade), o senso de mistério e o ímpeto revolucionário (DEUS, 2010, p. 9). Pelo olhar surrealista podemos reinterpretar o banal, o concebido, o institucionalizado, o "normal" e até mesmo o sério:

\begin{abstract}
O surrealismo, mais do que qualquer outro movimento de vanguarda, desintegra e integra ao mesmo tempo, pela raivosa confiança com que postula uma revolução que transforme a vida e a poesia, ou melhor, que transforme a vida em poesia. O surrealismo acredita no possível, no possível do homem e a arte supra, além da realidade pobre e medíocre que o sentido da utilidade do mundo capitalista arrumou para ela. Mas a realidade surrealista não está em outra realidade, não é um espaço transcendental; ela existe no maravilhoso cotidiano, que temos deixado de perceber. Destarte, a redescoberta do cotidiano enquanto estranho e imprevisível, longe de ser apenas um programa estético para o surrealismo, é uma práxis vital. (MENÉDEZ; CARIGNANO, 2007, p. 5)
\end{abstract}

O que o urrealismo propõe, então, não é necessariamente outra realidade, isto é, não se trata de um mundo concebido à parte do que experienciamos, nem além do que podemos conhecer, mas sim, trata-se de um olhar que nos permite conceber a nossa realidade de outra maneira. Trata-se de contemplar o mundo pela via da absurdidade, ou seja, por meio da insensatez, do fantástico, do que de alguma maneira repugna a razão, que perturba o sentido, que transgride o verossímil. Nessa percepção, o riso pode funcionar como essa abertura ao insólito no cotidiano:

O absurdo, elemento característico do humor moderno, o qual se desenvolve até atingir as incongruências do non sense, é próprio da realidade do homem contemporâneo: "Reconhecido o absurdo do mundo, se falará na sua mesma linguagem: a do absurdo" (Pizarnik, 2003, p. 197). É um humor que se rebela da lógica, do bom senso, dos hábitos, da "normalidade" e aponta para um tipo de pensamento contraditório, paradoxal, incongruente, oposto a toda racionalidade. (MENÉDEZ; CARIGNANO, 2007, p. 7). 
Nos memes, a absurdidade, em muitos dos casos, aparece como elemento central. Muitas vezes, é o próprio absurdo que se apresenta no cotidiano que inspira o processo de replicações meméticas, sendo realçado no devir dos memes. Em nosso objeto, essa dinâmica de intensificação do absurdo se dá através de montagens, rearranjo das imagens (paródias), e por vezes de forma escarnecedora, mas não exclusivamente.

O meme Yo Dawg, por exemplo, revela e intensifica uma possível "surrealidade" no mundo existente, e o faz ao escarnecer da dinâmica de um programa de televisão por meio da figura de um de seus idealizadores, o apresentador e cantor Alvin Nathaniel Joiner, mais conhecido por seu nome artístico Xzibit. No programa, Pimp My Ride, Xzibit restaurava e customizava o carro dos participantes, equipando o automóvel de acordo com o gosto e o estilo de vida do dono. Assim, além do conserto tradicional, como a troca de motores, espelhos, reparação na pintura, entre outros, a produção do programa ia além: a personalização dos veículos pelo Pimp My Ride já resultou em algumas absurdidades, como automóveis que continham um polidor de bola de boliche, uma secadora de roupas, 12 telas de TV e até mesmo uma lareira elétrica ${ }^{144}$. $\mathrm{O}$ exagero das customizações, associando ao veículo máquinas que nunca esperaríamos ver instaladas em um carro, inspirou uma imagem postada em 2007 no fórum 4chan (Figura 51). A ideia ganhou novas nuances (Figuras 52 a 55), estabelecendo pouco a pouco o meme Yo Dawg (“E aí, mano”).

Figura 51 - Imagem postada no 4chan.

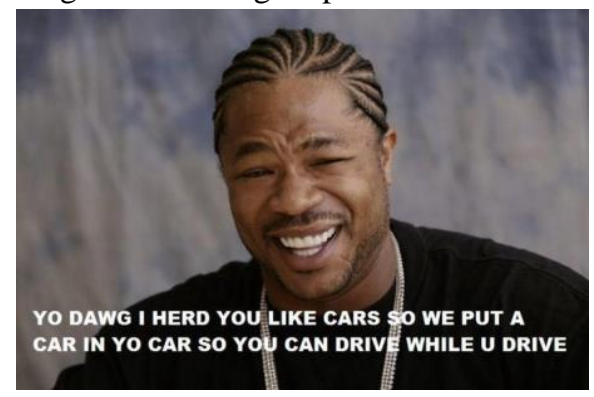

Fonte: knowyourmeme.com ${ }^{145}$

"E aí, mano! Ouvi dizer que você gosta de carros então a gente colocou um carro no seu carro, assim você pode dirigir enquanto dirige."

\footnotetext{
${ }^{144}$ Fonte: <http://www.tv.com/shows/pimp-my-ride-after-show/> Acesso em 3/9/2014.

145 <http://knowyourmeme.com/memes/xzibit-yo-dawg> Acesso em 3/9/2014.
} 
Figura 52 - Réplica do meme Yo Dawg.

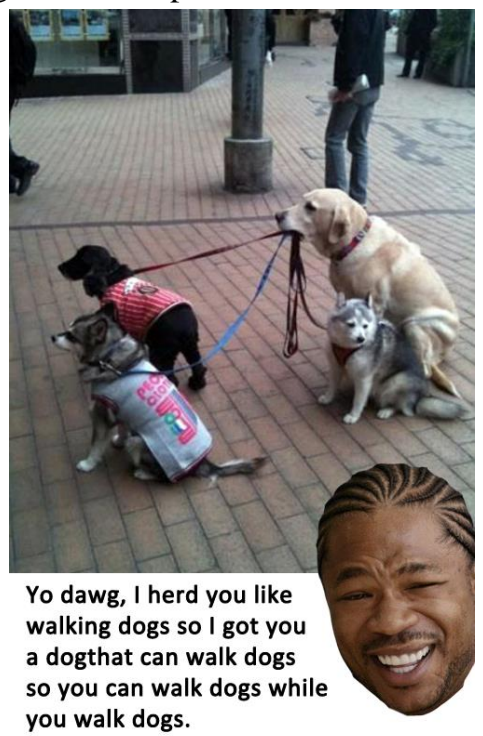

Fonte:

knowyourmeme.com ${ }^{146}$

"E aí, mano, ouvi dizer que você gosta de passear com cachorros então eu arrumei para você um cachorro que sabe passear com cachorros assim você pode passear com cachorros enquanto passeia com cachorros."

Figura 53 - Réplica do meme Yo Dawg.

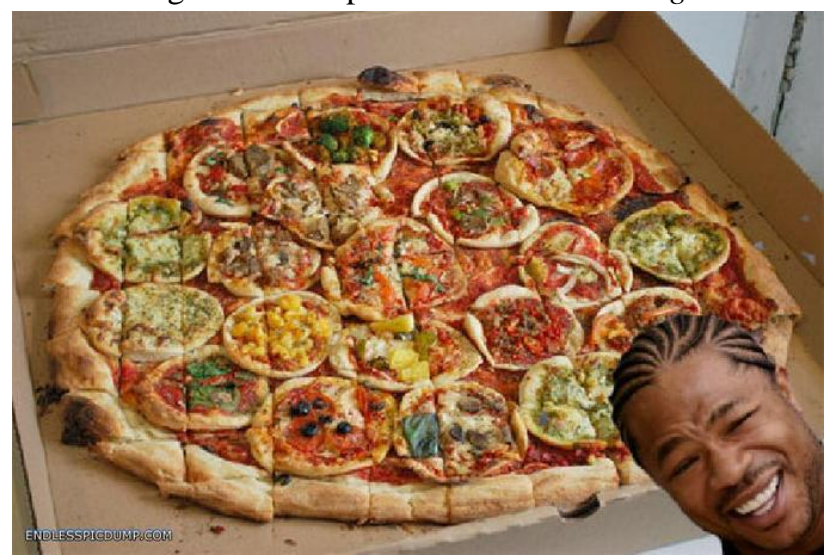

Fonte: knowyourmeme.com ${ }^{147}$

\footnotetext{
$146<$ http://knowyourmeme.com/memes/xzibit-yo-dawg > Acesso em 3/9/2014
} 147 <http://knowyourmeme.com/memes/xzibit-yo-dawg> Acesso em 3/9/2014. 
Figura 54 - Réplica do meme Yo Dawg.

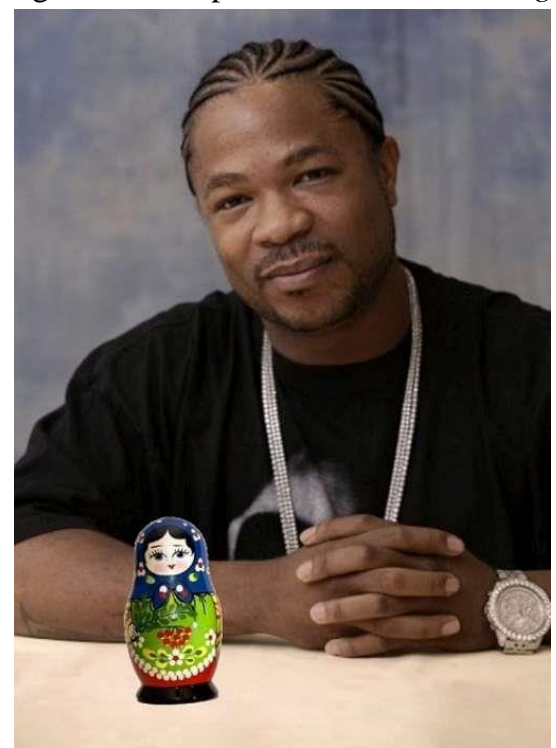

Fonte: www.hipsterwave.com ${ }^{148}$

Figura 55 - Réplica do meme Yo Dawg.

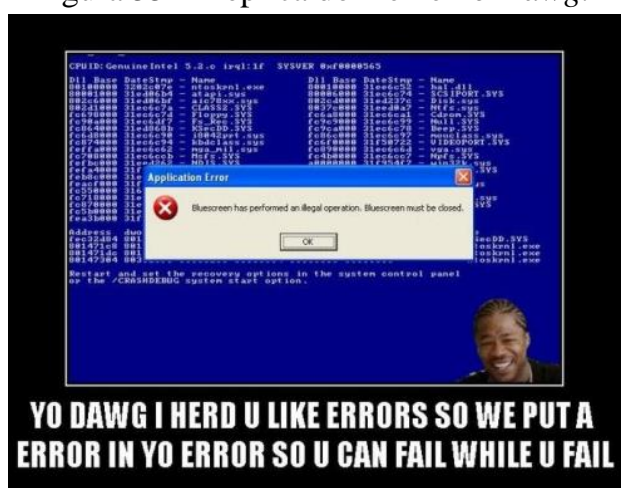

Fonte: knowyourmeme.com ${ }^{149}$

"E aí, mano, ouvi dizer que você gosta de erros então a gente colocou um erro no seu erro, assim você pode fracassar enquanto fracassa".

O princípio deste meme é apresentar sempre a ideia de algo que contém algo igual a si mesmo em imagens - sejam do nosso dia a dia, sejam criadas por montagem que nos causam certo estranhamento, tendo o apresentador Xzibit como demarcador da presença do insólito. Essas figuras acabam se tornando mais que simples composições curiosas, tornam-se risíveis, quando associadas ao repertório do programa de TV, o que dá certo tom de escárnio aos exageros da customização dos veículos em Pimp My Ride. A apropriação paródica reiterada nas diversas réplicas permite assim a associação de elementos heterogêneos que conduz a essa absurdidade risível. Nesse sentido, se

\footnotetext{
$148<$ http://www.hipsterwave.com/2009-03-28/xzibit-yo-dawg-meme/> Acesso em 3/9/2014.

149 <http://knowyourmeme.com/memes/xzibit-yo-dawg> Acesso em 3/9/2014.
} 
pensarmos em uma fórmula matemática pura e simplesmente (que pode ser uma fórmula que contém outra fórmula), ela não nos causa estranhamento. No entanto, quando entendida em associação a algo que lhe é alheio, uma fórmula matemática pode até mesmo ganhar contornos de absurdidade (Figura 56).

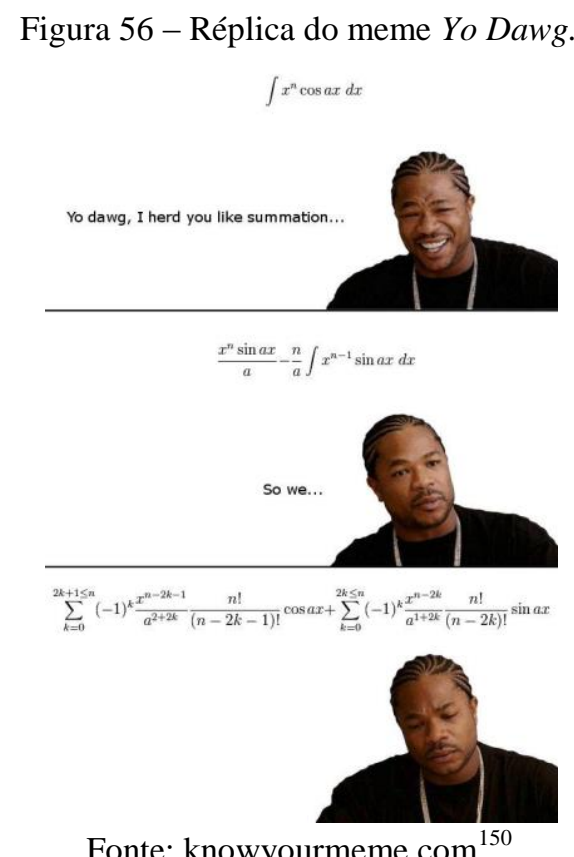

Outro meme que também nos permite visualizar o absurdo presente no fenômeno por meio de montagens é o Van Persieing. Trata-se das releituras da fotografia do momento do gol do jogador holandês Van Persie, na partida contra a Espanha na Copa do Mundo de 2014 no Brasil (Figura 57). O lance, que foi bastante enaltecido tanto por holandeses quanto por fãs do evento no mundo todo ${ }^{151}$, tornou-se ainda mais quimérico ao ganhar suas recriações meméticas (Figuras 58 a 61). Para completar, o gol também originou uma série fotográfica (photo $\mathrm{fad}^{152}$ ) de pessoas deitadas com a intenção de reproduzir a posição se Van Persie no gol (Figuras 62). Nesse caso, temos um exemplo em que a exageração absurda não intensifica favorecendo o escárnio, mas sim, de certa maneira, funciona como homenagem, como uma avaliação positiva da jogada de Van Persie.

\footnotetext{
$150<$ http://knowyourmeme.com/memes/xzibit-yo-dawg> Acesso em 3/9/2014.

$151<\mathrm{http}: / /$ knowyourmeme.com/memes/vanpersieing> Acesso em 3/9/2014.

${ }^{152}$ As photo fads, termo que podemos traduzir como "moda fotográfica" ou "mania fotográfica", corresponde a uma tendência de tirar fotografias em uma pose específica, normalmente com o propósito de serem compartilhadas online. Fonte: < http://knowyourmeme.com/memes/subcultures/photo-fads> Acesso em $14 / 9 / 2014$
} 
Figura 57 - Momento do gol de Van Persie.

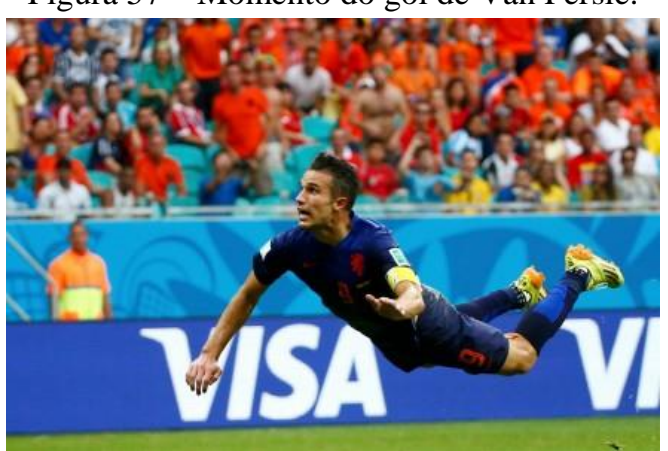

Fonte: veja.abril.com.br ${ }^{153}$

Figura 58 - Réplica do meme Van Persieing.

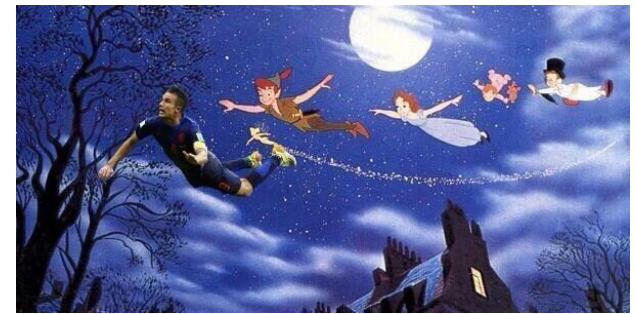

Fonte: knowyourmeme.com ${ }^{154}$

Figura 59 - Réplica do meme Van Persieing.

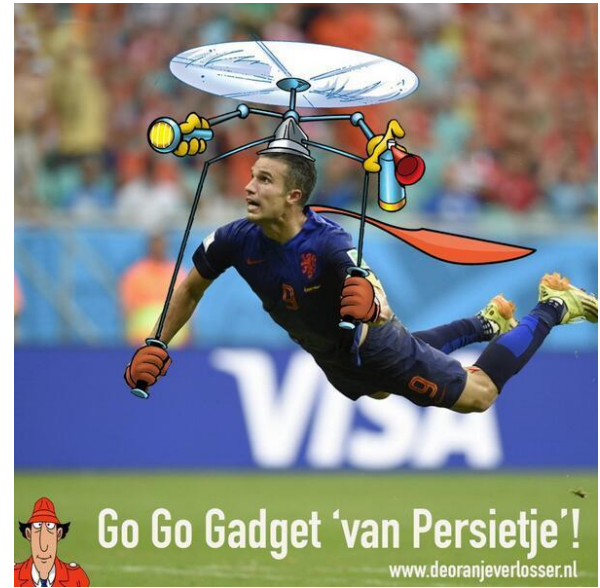

Fonte: knowyourmeme.com ${ }^{155}$

\footnotetext{
${ }^{153}<$ http://veja.abril.com.br/blog/ricardo-setti/tag/robin-van-persie/> Acesso em 3/9/2014

$154<\mathrm{http} / / / \mathrm{knowyourmeme.com/memes/vanpersieing/photos>} \mathrm{Acesso} \mathrm{em} \mathrm{4/9/2014}$

155 < http://knowyourmeme.com/memes/vanpersieing/photos> Acesso em 4/9/2014
} 
Figura 60 - Réplica do meme Van Persieing.

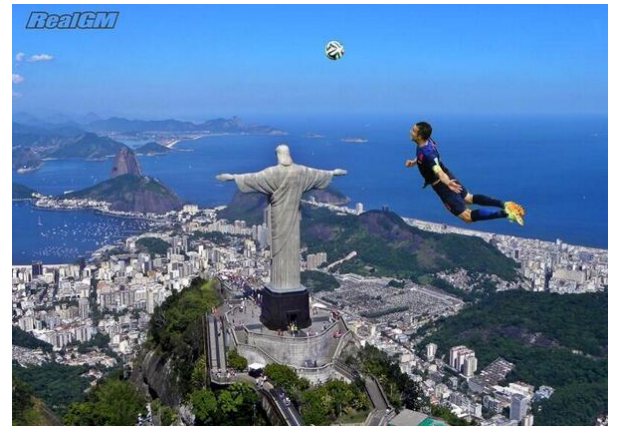

Fonte: www.101greatgoals.com ${ }^{156}$

Figura 61 - Réplica do meme Van Persieing.

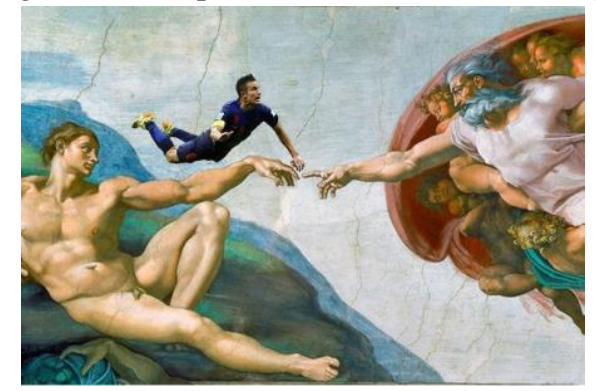

Fonte: knowyourmeme.com ${ }^{157}$

Figura 62 - Photo fads de Van Persie.
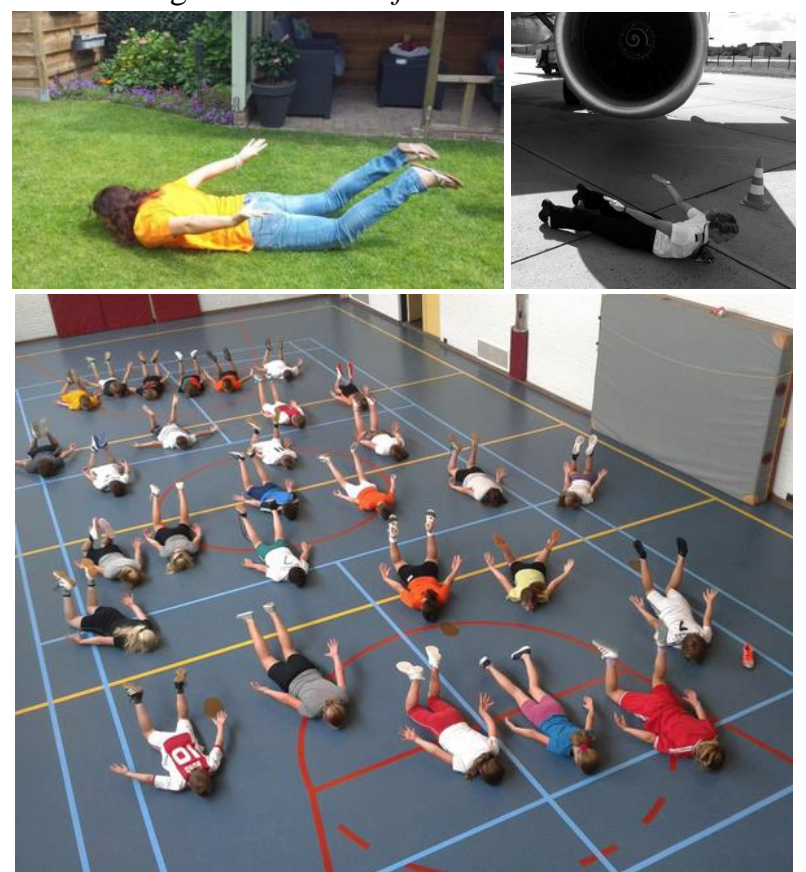

Fonte: www.girlscene.nl ${ }^{158}$

Fundamentando-nos no que foi ilustrado, ressaltamos aqui mais essa característica secundária do meme: o absurdo, por meio do qual podemos julgar nosso

\footnotetext{
${ }^{156}<$ http://www.101 greatgoals.com/blog/the-flying-dutchman-best-pictures-memes-of-rvp-flying-header-vspain/> Acesso em 4/9/2014

${ }_{157}<$ http://knowyourmeme.com/memes/vanpersieing/photos > Acesso em 4/9/2014

$158<\mathrm{http}: / /$ www.girlscene.nl/p/13663/internettrend_nrpersieing> Acesso em 4/9/2014
} 
cotidiano desde outro lugar, percebendo-o como imprevisível, fabuloso, fantástico, estranho. O absurdo permite, portanto, a crítica das relações lógicas, colocando-as para serem conjecturadas em outro universo, destruindo "uma realidade para que nasça uma outra nova da qual a primeira é apenas um córtex superficial" (DUPLESSIS apud MENÉDEZ; CARIGNANO, 2007, p. 6). Não são, portanto, realidades alheias, mas trata-se de uma "segunda realidade" que opera como uma releitura crítica de uma primeira.

O surrealismo nos apresenta, assim, uma possibilidade de ver o banal de outra maneira. É válido questionar aqui se em alguns casos já não há algo minimamente insólito que desponta nas situações, como nos exemplos dados. De todo modo, ainda que já possuam caráter de fait-divers, um elemento que nos faça estranhá-los, esses fatos que originam os memes poderiam passar desapercebidos, como algo corriqueiro e parte de nosso cotidiano, entretanto, ganham um aprofundamento crítico, isto é, são conduzidos a sair de sua normalidade quando precipitados ao supra-real - processo que pode se desenrolar na articulação do absurdo com o risível, especialmente em sua forma humorística, como nos mostram Menedéz e Carignano nas citações acima. E falar em humor é referir-se a um tipo especial de comicidade também chave na compreensão de nosso objeto.

\subsection{Comicidade e humor}

Muitos são os termos e categorias associados ao estudo do risível, "humor, ironia, comédia, piada, dito espirituoso, brincadeira, sátira, grotesco, gozação, ridículo, nonsense, farsa, humor negro, palhaçada, jogos de palavra ou simplesmente jogo" e, por vezes, as diferenças terminológicas não foram sublinhadas de maneira explícita pelos autores que estudaram o riso (ALBERTI, 2002, p. 25). Diante desse impasse, para nos referirmos ao objeto do riso, optamos por usar ora a palavra "risível" ora a palavra "cômica" (e "comicidade"), esta principalmente quando nos referimos aos estudos de Bakhtin, quem compreende o riso carnavalesco como uma concepção cômica do mundo. Verena Alberti, em seu estudo sobre o riso e o risível na história do pensamento, mostra que o termo "risível" corresponde àquilo de que se ri (a brincadeira, a piada, o jogo, a sátira etc.) e, na maioria dos casos, essa noção equivale ao que recebe o nome de cômico. Há autores, entretanto, que destacam distinções entre os termos. Desse modo, para sustentar nossa escolha e deslindar o conceito de humor que 
também fundamenta o entendimento do meme, discutiremos brevemente algumas variações de sentido que aparecem para a palavra "cômico", confrontando-as com a ideia de "humor".

Uma das noções de cômico com a qual nos deparamos está na divisão da tradição teórica alemã, apresentada por Alberti. Nesses estudos, o objeto do riso se ramifica em cômico (das Komische), chiste (Witz) e às vezes é acrescido o humor (Humor). A diferenciação entre eles não é tão simples e depende do esquema teórico de cada autor, porém, em geral, nessa divisão, das Komische consiste nas "ações, gestos ou expressões corporais como os que se observam no teatro ou nas ruas", Witz refere-se aos chistes e piadas, já o termo Humor não é especificado pela autora dentro dessa separação. Alberti afirma que a particularidade da categoria do chiste (Witz) só é alcançada em línguas como o inglês e o alemão que possuem as palavras wit e Witz, respectivamente, que apontam para uma especificidade ausente nas outras línguas que abordam o cômico de forma geral, às vezes dividindo-o em cômico das palavras e cômico de ações ou de situações (ibidem, p. 20). Em nosso entendimento, o cômico, nessa leitura da tradição alemã refere-se então ao risível não-verbal, distinguindo-se de um outro tipo de risível que pode ser contado, dito, posto em palavras.

Julio Cortázar também faz uma distinção entre termos relacionados ao riso: diferencia o humor da comicidade. Para ele, o humor contém algo de inexpressável que a comicidade não tem. Para esclarecer essa distinção, ele ilustra sua explicação com dois exemplos do cinema: Jerry Lewis, que para ele é alguém muito cômico, e Woody Allen, que seria um humorista. Em sua ponderação, Jerry Lewis busca simplesmente criar situações que vão nos fazer rir momentaneamente, mas não possuem nenhuma projeção, é algo que termina na própria piada. Já Woody Allen consegue extrapolar. Qualquer dos efeitos cômicos que ele consegue produzir "em seus melhores momentos estão cheios de sentido que vão muito além da piada ou da própria situação: contém uma crítica, uma sátira ou uma referência que pode ser inclusive muito dramática" (CORTÁZAR, 2013, p. 158, tradução nossa ${ }^{159}$ ). Ao ilustrar a distinção com filmes de Jerry Lewis, que é mais caricato e "pastelão", parece-nos que o entendimento de Cortázar se aproxima do que Alberti nos apresenta: o cômico, para ele, por essa explicação, poderia estar associado ao gestual. Cortázar, no entanto, acrescenta um

\footnotetext{
159 “[...] en sus mejores momentos están llenos de um sentido que va muchíssimo más allá del chiste o de la situación misma: contienen una crítica, una sátira o una referencia que puede ser incluso muy dramática"
} 
elemento importante na ideia de comicidade, para ele é simplesmente algo do qual rimos, sem uma reflexão posterior.

Bakhtin não chega a definir explicitamente o termo cômico, como faz Cortázar, mas essa noção de cômico associada aos gestos, ações e expressões corporais, que se observa no teatro ou nas ruas, também está esboçada em seus estudos. Se pensarmos no carnaval, por exemplo, parte de uma cultura cômica popular, ele proporcionava um apagamento entre a representação e a própria vida, "Na verdade, o carnaval ignora toda a distinção entre atores e espectadores. [...] Os espectadores não assistem ao carnaval, eles o vivem, uma vez que o carnaval pela sua própria natureza existe para todo o povo" (BAKHTIN, 1987, p. 6). Na experiência do carnaval, portanto, as pessoas o viviam corporalmente. No entanto, Bakhtin também usa o termo cômico para referir-se à literatura que incorporou a cultura cômica popular, como a própria obra de Rabelais. Então as ideias de Das Komische e Witz em Bakhtin parecem estar abrigadas pelo mesmo termo, cômico, principalmente quando o autor faz referência à cultura popular.

Além disso, a partir de nossa leitura, entendemos que Bakhtin também compreende o cômico como algo que está associado ao princípio do riso de maneira geral, pois mesmo em formas do riso que ele considera negativa ${ }^{160}$, como a sátira, aparecem termos como "comicidade satírica” (BAKHTIN, 1987, p. 44). Podemos acrescentar também que o cômico na concepção de Bakhtin é algo mais amplo que no entendimento de Cortázar, pois tratam-se de análises distintas. Cortázar faz uma breve descrição do cômico e nela o define em apenas um caso, filmes de Jerry Lewis. Bakhtin, apesar de não explicitar diretamente um conceito de termo cômico, o entende mais amplamente como o adjetivo que define uma cultura do riso. Nesse sentido, guardadas as proporções das análises de Bakhtin e Cortázar, é válido assinalar que, para o autor russo, o cômico, entendido no princípio do riso, não termina na piada. Como vimos, o riso é regenerador e nos permite acessar certos aspectos do mundo que não conseguimos por meio do sério.

Já o humor para Bakhtin seria uma forma atenuada do riso, característico do grotesco romântico: nessa tradição, o riso não desaparece, ele apenas abranda, deixando de ser jocoso e alegre (BAKHTIN, 1987, p. 33). Nesse sentido, o humor seria resultante da "romantização" do cômico (RICHTER apud MENÉDEZ; CARIGNANO, 2007, p.

\footnotetext{
${ }^{160}$ Bakhtin contrapõe o riso carnavalesco ao riso puramente satírico da época moderna, ressaltando que o autor satírico "emprega o humor negativo, coloca-se fora do objeto aludido e opõe-se a ele", diferente do riso popular ambivalente (carnavalesco) que "expressa uma opinião sobre um mundo em plena evolução no qual estão incluídos os que riem” (BAKHTIN, 1987, p. 11).
} 
2). E de fato podemos identificar a herança do grotesco romântico em algumas ideias de fundo que se projetam no humor, tais como a valorização da subjetividade (mundo interior), o estranhamento do mundo e o universo trágico, que de certa maneira estão presentes nessa forma de riso. Observemos a partir de algumas leituras como estes traços se manifestam no humor e como esta forma de riso está presente em nosso objeto proporcionando um tipo específico de reflexão.

Pensado por Luigi Pirandello em sua obra "O Humorismo", também em confrontação com a ideia de cômico, o humor é entendido de modo semelhante ao que é compreendido por Cortázar, no sentido de ser algo que vai além do cômico. Pirandello articula seu entendimento de humor a partir de uma ponderação sobre as obras de arte. Ele assinala que apesar de haver uma reflexão durante a concepção de uma obra de arte essa reflexão é invisível à consciência do artista, de modo que ele a percebe quase que como uma forma de sentimento. Ao passo que a obra se faz, a reflexão emerge, a partir das impressões que dela são recebidas:

\begin{abstract}
A consciência não ilumina todo o espírito; notadamente para o artista ela não é um lugar distinto do pensamento, que permita à vontade atingi-la qual a um tesouro de imagens e ideias. A consciência, em suma, não é uma potência criadora, mas o espelho interior no qual o pensamento que vê a si mesmo, assistindo aquilo que ele faz espontaneamente. E comumente, no artista, no momento da concepção, a reflexão se esconde e permanece, por assim dizer, invisível: é quase, para o artista uma forma do sentimento. À medida que a obra se faz, ela a critica, não friamente como faria um juiz desapaixonado, analisando-a, mas improvisadamente, segundo a impressão que dela recebe. (PIRANDELLO, 1996, p. 131)
\end{abstract}

Assim, para Pirandello, a distinção entre uma obra de arte e uma obra humorística emerge no instante de suas concepções, uma vez que na obra humorística essa reflexão não se esconde em sua invisibilidade:

[A reflexão] não permanece quase uma forma do sentimento, quase um espelho no qual o sentimento se mira; mas se lhe põe diante, como um juiz; analisa-o, desligando-se dele; descompõe a sua imagem; desta análise, desta decomposição, porém, surge e emana um outro sentimento: aquele que poderia, chamar-se, e que eu de fato chamo o sentimento do contrário. (PIRANDELLO, 1996, p. 132).

Essa elucubração pode ser mais bem compreendida se a relacionamos com o que Pirandello reflexiona sobre o cômico, pensando-o em sua relação com o humor. Ele nos propõe uma situação na qual vê uma senhora com os cabelos de cor carregada, oleoso, vestida com roupas juvenis e com uma maquiagem desajeitada e ele começa a rir. Nesse caso, tem-se uma advertência do contrário, adverte que "aquela velha senhora é o contrário do que uma velha senhora respeitável deveria ser" (idem.), configurando assim 
o cômico, nada mais que um aviso. No entanto, se dessa cena emerge uma reflexão de que talvez aquela senhora não goste de suas roupas e que na realidade sofre, vestindo-se assim porque crê que desse modo irá manter o amor de seu marido, muito mais jovem, essa reflexão não permite que se ria dessa situação mais como antes. A reflexão proporciona um salto no entendimento: "trabalhando em mim, fez-me ir para além daquela primeira advertência, ou de preferência mais adentro: daquela primeira advertência do contrário fez-me passar a este sentimento do contrário. E aqui está toda a diferença entre o cômico e o humorístico" (idem).

Nesse sentido, para Pirandello, o cômico é o que nos faz rir simplesmente, como resultado de uma percepção, já o humor é uma reflexão que vai além desse simples riso. Trata-se, no entanto, de uma reflexão especial que torna o riso amargo. Para Pirandello a representação humorística, a partir das impressões que ela nos passa, desperta em nós um estado de espírito de perplexidade, no qual gostaríamos de rir, rimos, mas é um riso impedido e perturbado por algo que provém da própria representação (ibidem, p. 136).

Em nosso objeto, esse tipo de provocação do humor de que nos fala Pirandello fica bem evidente no meme Third World Success ${ }^{161}$ (Sucesso do Terceiro Mundo) (figura 63), por exemplo. Essa série de imagens é formada sempre pela mesma fotografia de uma criança de uma tribo dançando, com legendas que remetem à superação de alguma dificuldade ou privação associada à vida em lugares em situação de miséria.

Figura 63 - Réplicas do meme Thrid World Success.
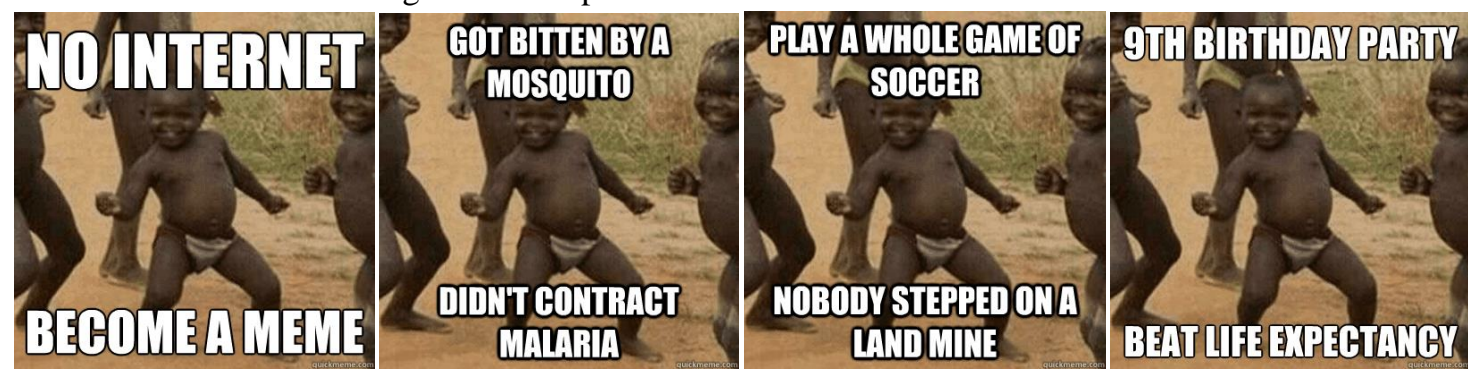

Fonte: knowyourmeme.com ${ }^{162}$

Réplica 1: "Não tem internet, torna-se um meme". Réplica 2: "É mordido por um mosquito, não contrai malária”. Réplica 3: Joga uma partida de futebol inteira, ninguém pisa em uma mina terrestre”. Réplica 4: "Aniversário de nove anos, bate a expectativa de vida".

Nesse sentido, o sentimento do contrário seria então uma mistura do cômico e de seu oposto, o trágico, algo que une riso e compaixão. Há quem ria dessas imagens,

\footnotetext{
${ }^{161} \mathrm{http}: / /$ knowyourmeme.com/memes/third-world-success

$162<\mathrm{http} / / /$ knowyourmeme.com/memes/third-world-success > Acesso em 5/9/2014
} 
mas não se trata de um riso confortável. O cômico, que é uma advertência do contrário, no humor, torna-se áspero.

De modo semelhante, como mencionamos, Cortázar também entende a diferença entre o cômico e humor pela provocação reflexiva que este último proporciona em suas representações. Para Pirandello a reflexão é "como um demoniozinho que desmonta a combinação de cada imagem, de cada fantasma colocado sobre o sentimento", desmonta-se "para ver como é feita, [para] quebrar a sua mola e ranger todo o seu mecanismo, convulso" (PIRANDELLO, 1996, p. 146). Cortázar também vê no humor a atitude desse "demoniozinho" de que fala Pirandello. Para o escritor argentino, essa forma de riso pode ser vista como um grande destruidor, mas que, ao destruir, constrói. É o que ele nos mostra ao fazer uma metáfora com a obra de um túnel, aduzindo que, para tal empreendimento, é preciso remover a terra, fazer um grande buraco, destruir tudo que havia antes, e com essa destruição construímos o túnel: “O mecanismo do humor funciona um pouco assim: derruba valores e categorias usuais, dá a volta nelas, as mostra do outro lado e bruscamente pode fazer saltar coisas que no costume, no hábito, na aceitação cotidiana não víamos, ou não víamos bem” (CORTÁZAR, 2013, p. 161 e 162, tradução nossa ${ }^{163}$ ).

Um meme que ilustra bem esse mecanismo evidenciado por Pirandello e Cortázar é o meme First World Problems (Problemas de Primeiro Mundo) (Figura 64), um equivalente ao meme brasileiro Classe Média Sofre, frase utilizada repetidamente na internet. $\mathrm{O}$ meme é formado pela fotografia de uma mulher chorando, retirada de um banco de imagens (com variações para outras fotografias, por exemplo um garoto adolescente sentado no chão), acompanhada sempre de uma reclamação fútil, a fim de ridicularizar "problemas" que só pessoas financeiramente favorecidas possuem ${ }^{164}$.

\footnotetext{
${ }^{163}$ Tradução nossa do trecho: "El mecanismo del humor funciona un poco así: echa abajo valores y categorias usuales, las da vuelta, las muestra del otro lado y bruscamente puede hacer saltar cosas que em la costumbre, en el hábito, em la aceptación cotidiana, no veíamos o veíamos menos bien."

${ }^{164}$ Fonte: <http://www.youpix.com.br/tag/first-world-problems/> Acesso em 24/1/2014.
} 
Figura 64 - Réplicas do meme First World Problems.
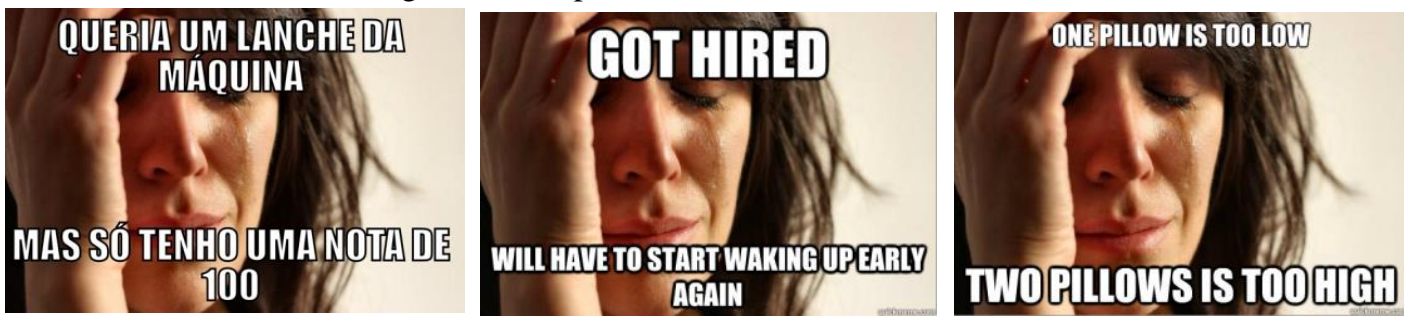

Fontes: blog.ipompovodomar.org.br ${ }^{165}$ (réplica 1) e biscoitossortidos.com ${ }^{166}$ (réplicas 2 e 3).

Réplica 2: "Fui contratado, vou ter que começar a acordar cedo de novo". Réplica 3: "Um travesseiro é muito baixo, dois travesseiros é muito alto".

Pensadas na lógica desse meme, as situações nele retratadas passam a ser de certa forma uma provocação que permite ver a banalidade dos fatos que às vezes são entendidos como grandes problemas. É uma lógica semelhante a que opera no meme Willy Wonka Irônico (figura 65), para dar outro exemplo, que com o seu sarcasmo coloca seu interlocutor hipotético para pensar em suas contradições, denunciando criticamente o contrassenso de alguns de seus comportamentos e atitudes ou mesmo derrubando algumas crenças que o interlocutor tem de si mesmo.

Figura 65 - Réplicas do meme Willy Wonka Irônico.
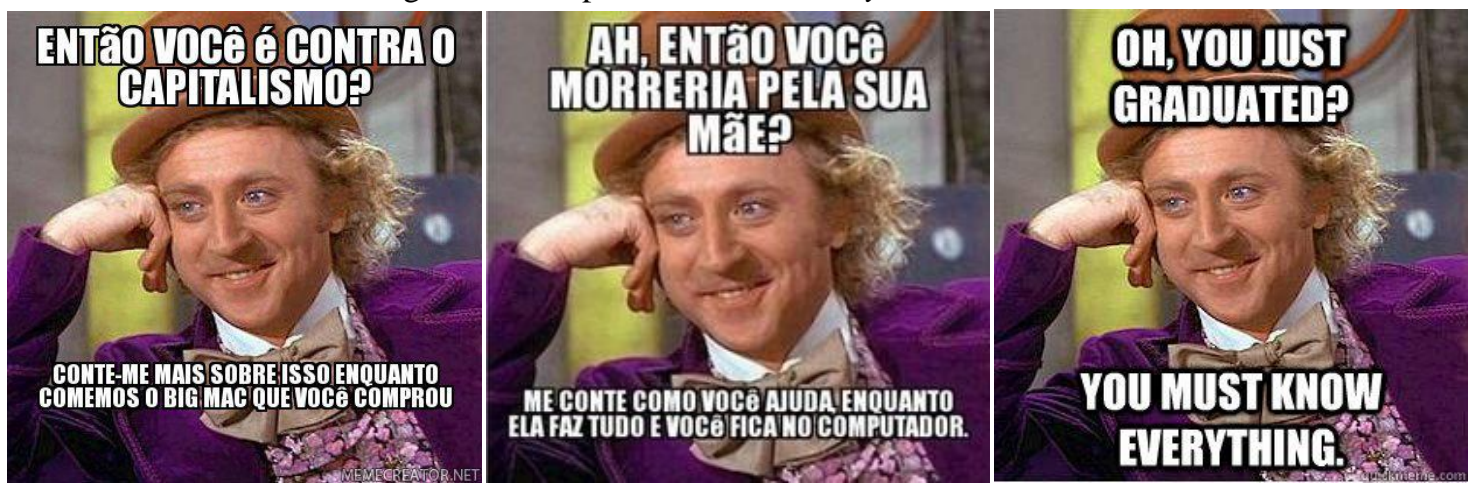

Fontes: entretenimento.r7.com ${ }^{167}$ (réplicas 1 e 2) e knowyourmeme.com ${ }^{168}$ (réplica 3).

Réplica 3: "Ah, você acabou de se formar? Você deve saber tudo".

Nesse sentido o humor pode nos fazer rir de nós mesmos, como propõe Richter. Para ele o traço essencial dessa forma do riso é a sua universalidade, que o diferencia do simples escárnio:

A universalidade supõe a generalização de toda vituperação particular; o que está em jogo no humorismo, não é, como no caso da crítica burlesca, o indivíduo, mas sim a humanidade. O humor é o cômico da natureza humana,

\footnotetext{
$165<$ http://blog.ipompovodomar.org.br/meme-solidario/> Acesso em 29/1/2014.

$166<$ http://biscoitossortidos.com/2012/11/20/firstworldproblems-do-meme-a-realidade/> Acesso em $28 / 1 / 2014$

167 Disponíveis em: < http://entretenimento.r7.com/cinema/fotos/willy-wonka-ironico-2012042316.html\#fotos> Acesso em 29/1/2014.

${ }^{168}$ < http://knowyourmeme.com/memes/condescending-wonka-creepy-wonka> Acesso em 29/1/2014.
} 
e não de uma individualidade especifica: o humorista, em oposição ao cômico, não ri de alguém, mas manifesta um desprezo pelo mundo, onde se inclui a ridicularização de si mesmo. (RICHTER apud MENÉDEZ; CARIGNANO, 2007, p. 2)

Por essa passagem, o que diferenciaria humor e cômico para Richter seria o alvo do riso, sendo o cômico um simples escárnio, o ato de rir de alguém. Já seus apontamentos sobre o humor revelam um aspecto que se evidencia em muitos memes que é o de colocar o "próprio eu" na mira do riso, e ao rir de si mesmo, o humorista provoca uma forte identificação com o seu leitor ou público (MENÉDEZ; CARIGNANO, 2007, p. 2). No caso de alguns memes, rir de si, mais que compaixão, pode engendrar um sentimento de empatia. Como exemplo, temos o meme Anxiety Cat (Gato da Ansiedade) (Figura 66), uma série de fotolegendas, nas quais há sempre a imagem de um gato de aparência assustada acompanhada por textos relacionados a reações paranoicas ou que retratam uma dificuldade de socialização.

Figura 66 - Réplicas do meme Anxiety Cat.
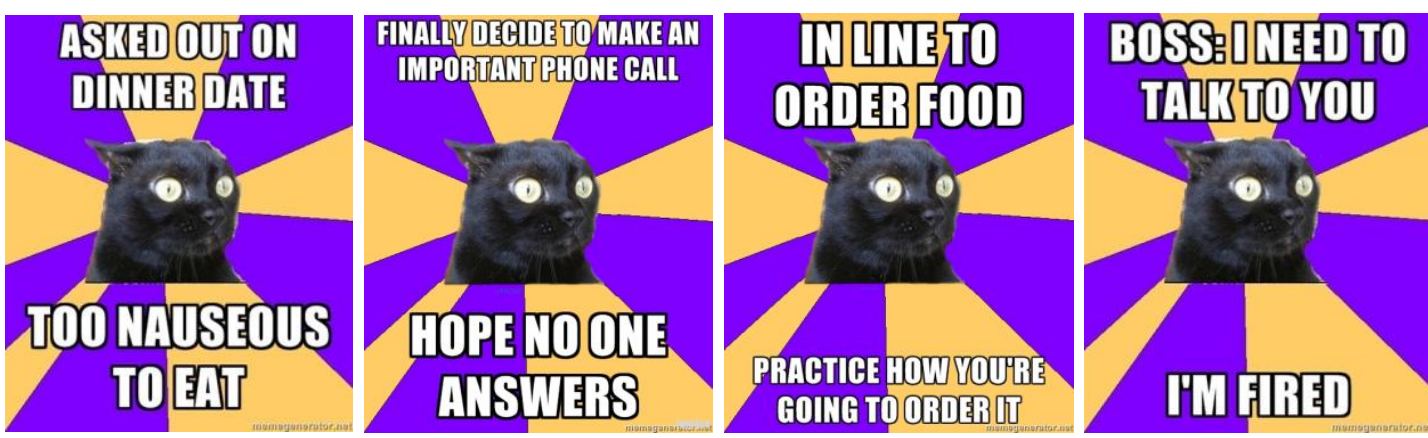

Fonte: knowyourmeme.com ${ }^{169}$

Réplica 1: "É chamado para um encontro em um jantar, está enjoado demais para comer". Réplica 2: "Finalmente decide fazer uma ligação importante, torce para que ninguém atenda o telefone". Réplica 3:

$\mathrm{Na}$ fila para fazer o pedido da comida, treina como vai pedir". Réplica 4: "Chefe: "preciso falar com você', estou demitido".

Outro exemplo de memes que engendram esse sentimento de empatia são as rage comics (figuras 67 a 70), tirinhas que podem ser feitas no Microsoft Paint ${ }^{170}$ e que são elaboradas a partir das rage faces, desenhos padronizados que se repetem em diversas histórias, feitos com aparente descuido e que representam o sentimento do personagem em relação à situação retratada.

\footnotetext{
169 < http://knowyourmeme.com/memes/anxiety-cat/photos> Acesso em 14/9/2014

${ }^{170}$ Programa de edição e produção de imagens com recursos simples.
} 
Figura 67 - Rage comic 1 (Me Gusta $\left.{ }^{171}\right)$.

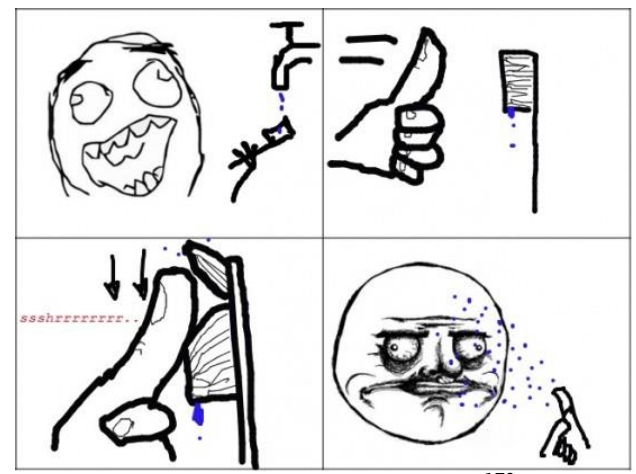

Fonte: memeblender.com ${ }^{172}$

Figura 68 - Rage comic 2 (Forever Alone ${ }^{173}$ ).

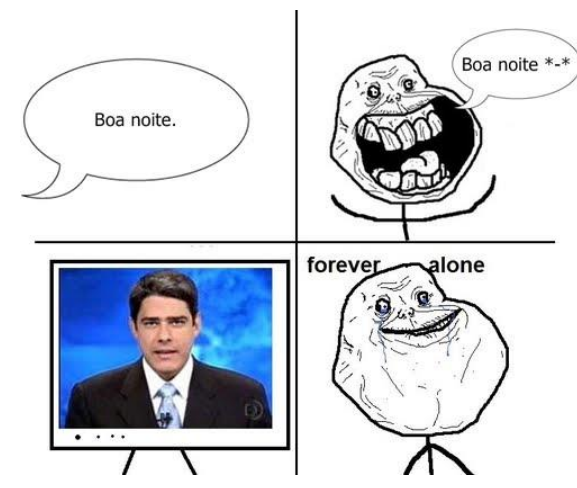

Fonte: www.fuckyeaworld.com ${ }^{174}$

Figura 69 - Rage face (Forever Alone).

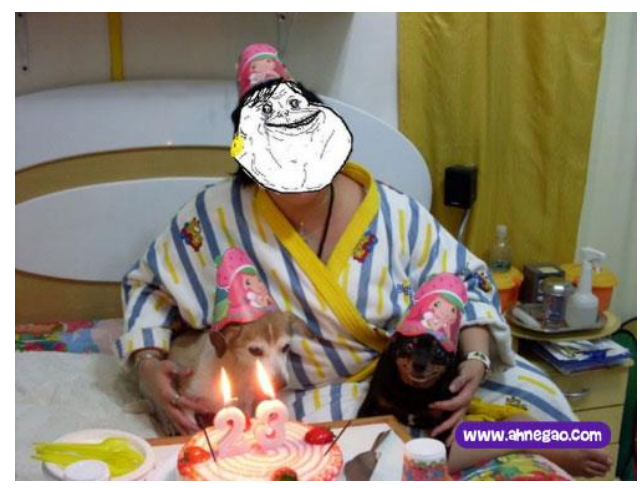

Fonte: www.ahnegao.com.br ${ }^{175}$

\footnotetext{
${ }^{171}$ O Me Gusta, que está no último quadro da tirinha, é uma rage face utilizada para representar situações nas quais o personagem sente prazer e se sente perturbado ao mesmo tempo. Fonte: < http://knowyourmeme.com/memes/me-gusta> Acesso em 29/1/2014.

${ }_{172}$ Disponíveis em: < http://memeblender.com/2012/01/19/me-gusta-meme-toothbrush/ >Acesso em $29 / 1 / 2014$

${ }^{173}$ O Forever Alone é uma rage face utilizada para retratar o sentimento de solidão ou desapontamento com a vida. Fonte:< http://knowyourmeme.com/memes/forever-alone> Acesso em 14/9/2014.

${ }^{174}<$ http://www.fuckyeaworld.com/2010/09/forever-alone-1.html> Acesso em 14/9/2014.

175 < http://www.ahnegao.com.br/t/forever-alone/page/8> Acesso em 14/9/2014.
} 
Figura 70 - Rage comic 3 .

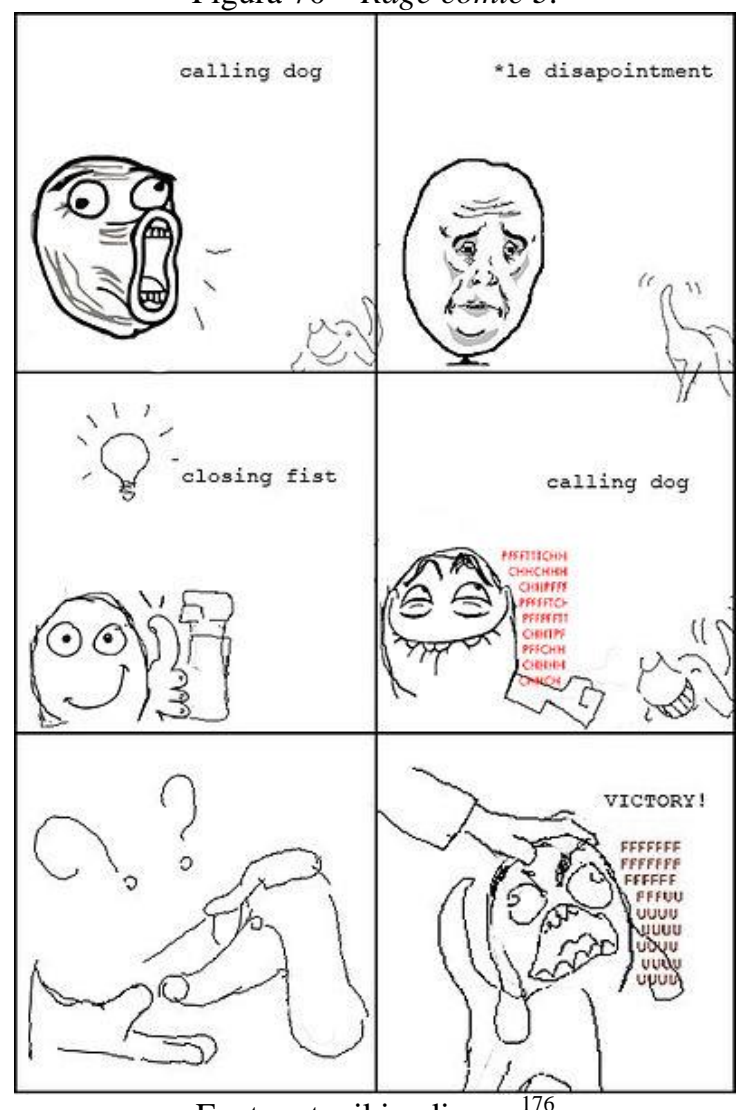

Fonte: pt.wikipedia.org ${ }^{176}$

Quadro 1: "chamando o cachorro" ( $L O L$ Guy $\left.{ }^{177}\right)$.

Quadro 2: "o desapontamento" (Okay Guy $\left.{ }^{178}\right)$.

Quadro 3: "fechando o punho". Quadro 4:

"chamando o cachorro" (PFFFTTTCHH $\left.{ }^{179}\right)$. Quadro

6: "vitória!" (Rage Guy $\left.{ }^{180}\right)$.

As situações que aparecem nessas ocorrências meméticas remontam os sentimentos e as experiências que provavelmente já foram vividos pelos interlocutores ou hábitos peculiares que cotidianamente não recebem muita atenção. A partir do momento em que esses sentimentos, experiências e hábitos são retratados no meme, sua representação os coloca em circunstâncias que permitem o seu estranhamento. $O$ interlocutor se identifica com o que está sendo ali retratado e o fato de ser um comportamento associado a um animal, como no Anxiety Cat, ou uma situação

${ }^{176}<$ http://pt.wikipedia.org/wiki/Rage_comics>Acesso em 29/1/2014.

${ }^{177} \mathrm{O}$ LOL Guy é normalmente empregado para indicar risada ou divertimento. Fonte: < http://knowyourmeme.com/memes/lol-guy> Acesso em 29/1/2014.

${ }^{178}$ O Okay Guy é a imagem de um rosto com uma expressão soturna, geralmente utilizada nas Rage Comics para exprimir um sentimento de conformação desesperançosa. Fonte: < http://knowyourmeme.com/memes/okay-guy> Acesso em 29/1/2014.

${ }_{179}$ O "PFFFTTTCHH" é usado para em situações em que o personagem em questão mal consegue segurar o riso. Fonte: < http://knowyourmeme.com/search?q=PFFFTTTCHH> Acesso em 29/1/2014.

${ }^{180} \mathrm{O}$ Rage Guy foi a primeira rage face criada e a que deu origem às Rage Comics. Ele é utilizado para retratar situações de raiva ou exasperação. Fonte: < http://knowyourmeme.com/memes/rage-guy-fffffuuuuuuuu> Acesso em 29/1/2014. 
representada caricaturalmente como nas rage comics, desloca a situação do ponto de vista que costumamos percebê-las. Outro fator que contribui para essa nova percepção é o fato de essas situações poderem ser midiatizadas nos memes, o que reforça a identificação ao revelar uma espécie de vivência coletiva dessas experiências.

Evidenciadas nas ocorrências meméticas, essas situações são encaradas de outro modo: algo que se faz sem pensar, corriqueiramente, mas que, representadas nessa linguagem, ganham uma projeção pela midiatização e pelo sentimento de estranhamento despertado. Essa estranheza é mostrada por Cortázar em seu texto humorístico "Instruções para subir uma escada ${ }^{181 ",}$, que aqui apresentamos um pequeno trecho:

As escadas se sobem de frente, porque de trás ou de costas parecem particularmente incômodas. A atitude natural consiste em manter-se de pé, os braços pendendo sem esforço, a cabeça erguida, mas nem tanto que os olhos deixem de ver os degraus imediatamente superiores em que se pisa, e respirando lenta e regularmente. Para subir uma escada se começa levantando essa parte do corpo situada à direita e abaixo, envolta quase sempre em coro ou camurça e que salvo exceções cabe exatamente no escalão. Posta no primeiro degrau dita parte, que para abreviar chamaremos de pé, se recolhe a parte equivalente da esquerda (também chamada de pé, mas que não há de se confundir com o pé antes citado), e o segundo degrau, com o qual neste descansará o pé, e no primeiro descansará o pé. (Os primeiros degraus são sempre os mais difíceis, até adquirir a coordenação necessária. A coincidência de nome entre o pé e o pé faz difícil a explicação. Tenha cuidado especialmente de levantar o pé e o pé). (CORTÁZAR, 2013, p. 162163 , tradução nossa ${ }^{182}$ )

Com esse texto, Cortázar tinha a intenção de provocar o estranhamento em algo que conhecemos tão bem e que fazemos sem pensar como é o ato de subir escadas. Ao decompor a ação, por meio do riso humorístico, por mais banal que subir escadas seja, colocamos essa atividade em outro lugar de entendimento, podendo projetar o pensamento a tantas outras atividades que fazemos sem pensar em como e por que as fazemos. Cortázar diz que não tinha nenhuma intenção moralizante, ética ou sociológica, o fez simplesmente pelo jogo que isso significava (ibidem, p. 164).

Também os memes, ilustrados nos exemplos, propõem sempre um jogo que brinca com as significações e convidam aqueles que irão replicá-lo a entrar nesse jogo,

\footnotetext{
181 "Instrucciones para subir una escalera"

182 "Las escaleras se suben de frente, pues hacia atrás o de costado resultan particularmente incómodas. La actitud natural consiste en mantenerse de pie, los brazos colgando sin esfuerzo, la cabeza erguida aunque no tanto que los ojos dejen de ver los peldaños inmediatamente superiores al que se pisa, y respirando lenta y regularmente. Para subir una escalera se comienza por levantar esa parte del cuerpo situada a la derecha abajo, envuelta casi siempre en cuero o gamuza, y que salvo excepciones cabe exactamente en el escalón. Puesta en el primer peldaño dicha parte, que para abreviar llamaremos pie, se recoge la parte equivalente de la izquierda (también llamada pie, pero que no ha de confundirse con el pie antes citado), y llevándola a la altura del pie, se le hace seguir hasta colocarla en el segundo peldaño, con lo cual en éste descansará el pie, y en el primero descansará el pie. (Los primeros peldaños son siempre los más difíciles, hasta adquirir la coordinación necesaria. La coincidencia de nombre entre el pie y el pie hace difícil la explicación. Cuídese especialmente de no levantar al mismo tiempo el pie y el pie)".
} 
“encaixando" uma experiência em seu modelo - experiência essa que tem um caráter particular e coletivo ao mesmo tempo, por ser partilhada. Assim, podem "rir de si mesmo" como nos aponta Richter. Georges Minois, ao abordar o humor no século XX, nos mostra que essa forma de riso requer a cumplicidade e a participação do interlocutor: o humor "gera uma simpatia, vinda da solidariedade diante das desgraças e dificuldades do grupo social, profissional, humano. É então que se percebe a dimensão defensiva do humor, arma protetora contra a angústia" (MINOIS, 2003, p. 559). Desse modo, a autoderrisão é tanto identificar-se com a situação particular retratada, quanto identificar-se com o grupo que vivencia aquilo e, em um sentido mais global, podemos dizer que o "rir de si mesmo" é o rir da nossa condição humana, rir da humanidade e de tudo que nela há, inclusive nós mesmos, como nos mostra Richter.

Por fim, ressalta-se também o caráter crítico do humor, já esboçado em nossa discussão sobre essa forma de riso. Em sua análise do grotesco, Raquel Paiva e Muniz Sodré enumeram algumas "modalidades expressivas" dessa categoria, entre elas o grotesco crítico, com a qual o humor está relacionado, aparecendo em alguns dos exemplos citados pelos autores. Esta modalidade caracteriza-se por proporcionar "um discernimento do objeto visado. Ou seja, não propicia apenas uma privada percepção sensorial do fenômeno, mas principalmente o desvelamento público e reeducativo do que nele se tenta ocultar" (SODRÉ e PAIVA, 2002, p. 69). Dessa maneira, o humor "reeduca", no sentido de nos proporcionar outra apreensão dos fatos, desencobrindo por meio do riso algo que esteja imperceptível (oculto) ou que não receba a sua devida importância, e é nesse sentido que consiste a crítica. O riso permite que se desestabilize a aceitação dos fatos, trazendo à tona uma postura em relação a eles. Nesse sentido, somente compreendendo o mundo como um objeto risível é que se pode lidar com ele. Dando um entendimento mais romântico para o humor: "só o riso pode nos salvar e nos redimir. Ou rimos ou, então, morremos todos de decepção com o ser humano" (PINTO, 2005, p. 12).

Projetando essa reflexão para o nosso objeto, observamos que os memes acabaram se tornando a válvula de escape moderna para expressar a perplexidade em relação aos fatos do mundo, operando também como uma maneira de compreender esses fatos, como vimos nos exemplos. As imagens dos acontecimentos ganham velozmente recriações quase que concomitantemente à sua ocorrência. Muitas vezes, essas recriações são simplesmente escarnecedoras, no entanto, algumas delas também evidenciam uma atitude crítica em relação aos eventos, como podemos ressaltar no 
meme emergente em resposta à mudança no programa de governo da então candidata à presidência da República, do Partido Socialista Brasileiro (PSB), Marina Silva. O programa incluía a defesa do casamento civil igualitário e a criminalização da homofobia e, em menos de 24 horas do seu lançamento, o programa foi remendado, excluindo-se dele essas duas propostas, com a justificativa de que teria havido uma "falha processual na editoração do texto ${ }^{183 "}$ ". Acreditou-se que o recuo de Marina em relação a esses dois pontos polêmicos tenha se dado pela rejeição de lideranças evangélicas, que configuram parte do seu eleitorado. Atribuiu-se ao seu recuo principalmente a manifestação da opinião do pastor Silas Malafaia na rede social Twitter (Figura 71).

Figura 71 - Tweets do pastor Silas Malafaia.

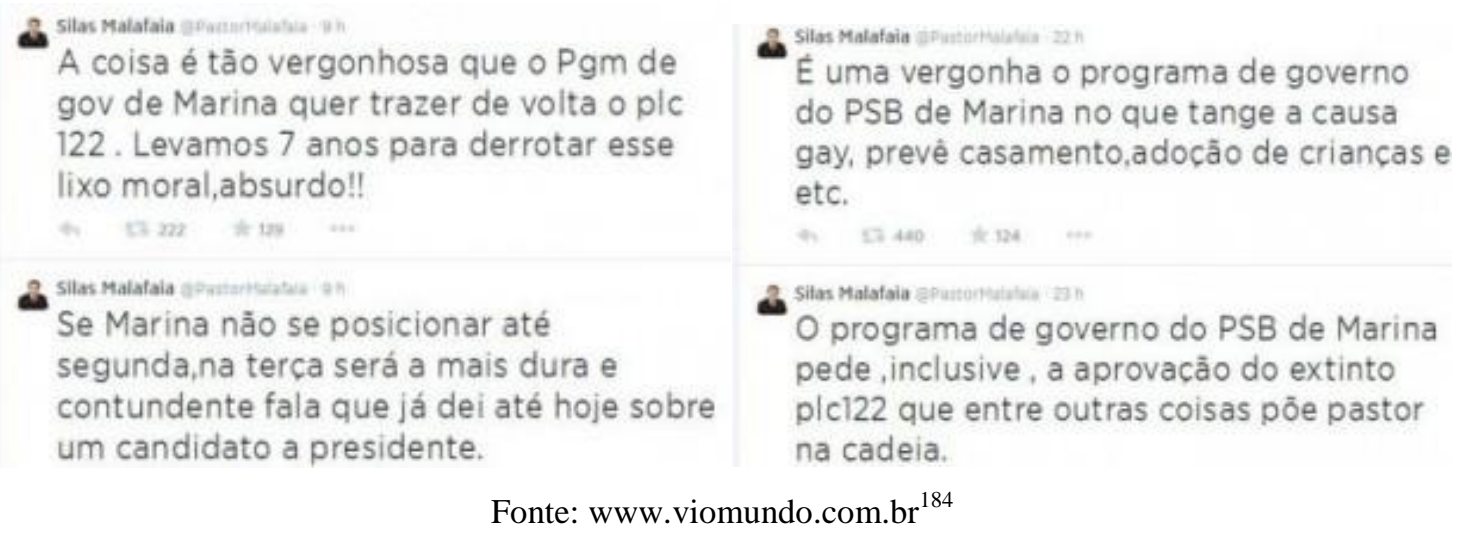

Os comentários de Malafaia seguidos da revisão do programa de governo de Marina foram motivação o suficiente para a criação de uma série de tirinhas nas quais Marina é sempre repreendida por Malafaia, mudando de opinião para não desagradar o líder evangélico (Figura 72 a 75).

\footnotetext{
${ }^{183}$ Fonte da citação: <http://zh.clicrbs.com.br/rs/noticias/eleicoes-2014/noticia/2014/08/pressionada-por-pastormarina-silva-muda-plano-de-governo-4588091.html> Acesso em 3/9/2014

${ }^{184}<$ http://www.viomundo.com.br/politica/toni-reis.html> Acesso em 3/9/2014
} 
Figura 72 - Réplicas do meme Marina Silva e Silas Malafaia..

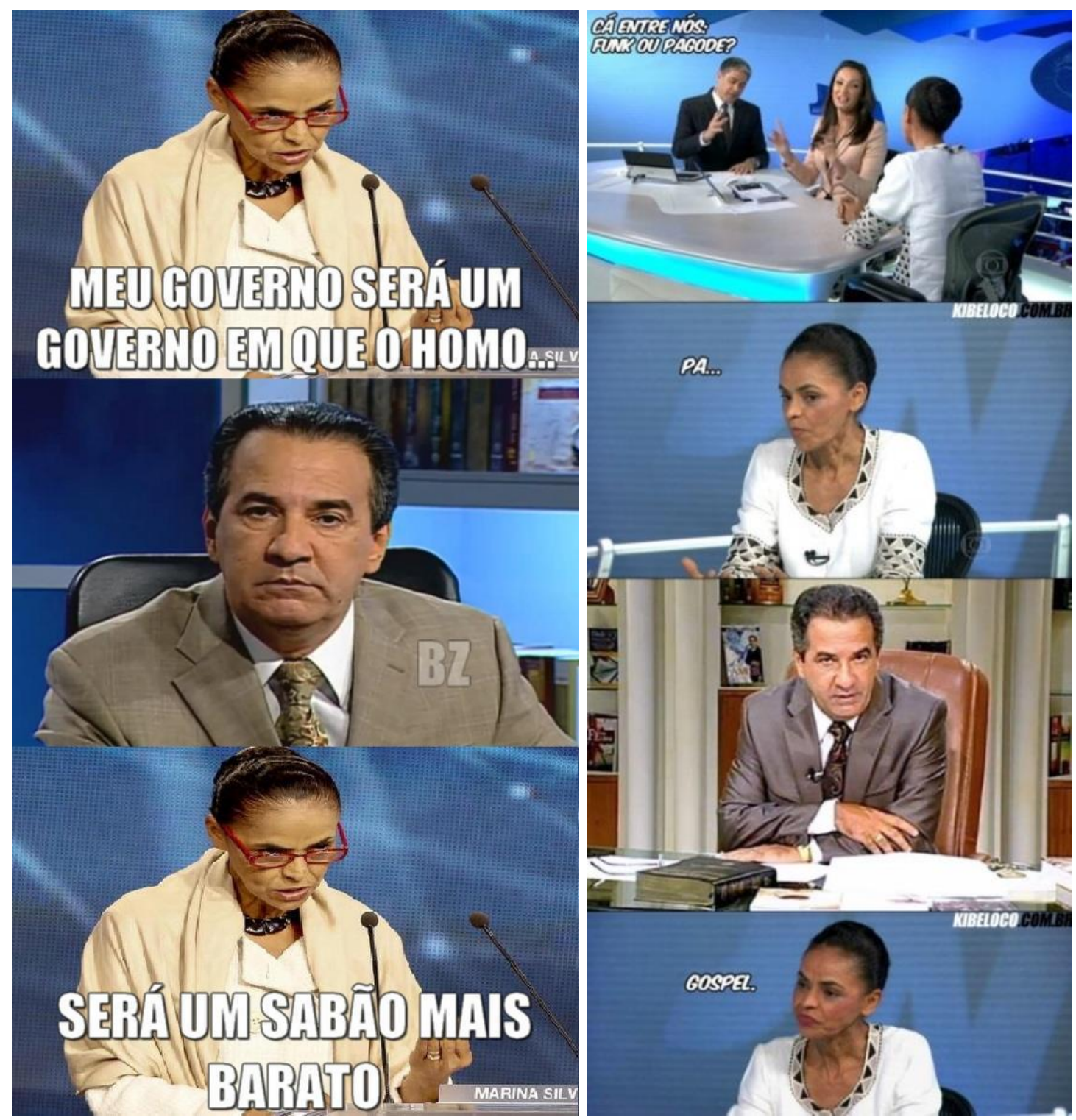

Fonte: noticias.gospelmais.com.br ${ }^{185}$

$185<$ http://noticias.gospelmais.com.br/marina-silva-influencia-pastor-silas-malafaia-70830.html> Acesso em $3 / 9 / 2014$ 
Figura 73 - Réplica do meme Marina Silva e Silas

Malafaia.

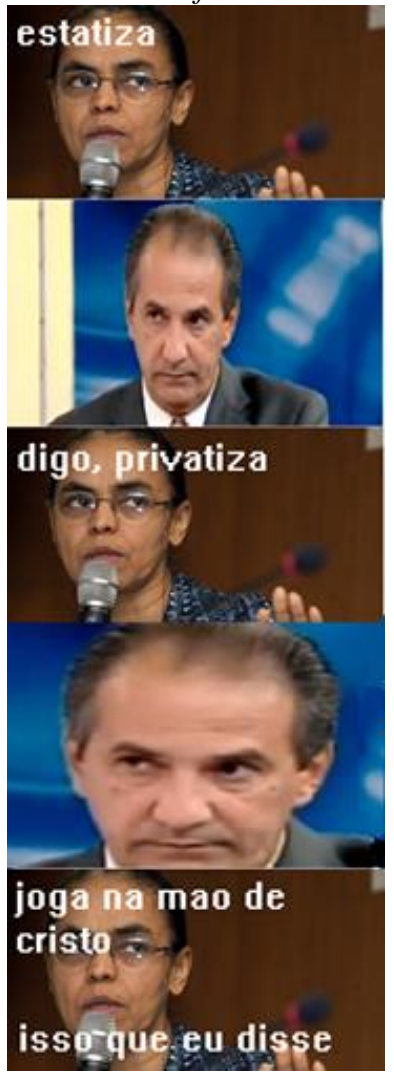

Fonte:

www.facebook.com/Meme Consciente $^{186}$

Figura 74 - Réplica do meme Marina Silva e Silas Malafaia..

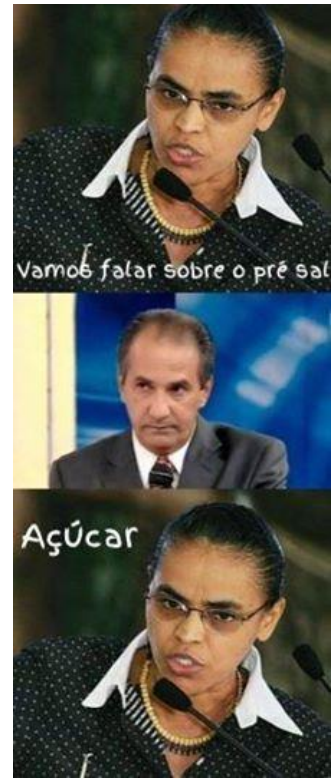

Fonte: facebook.com ${ }^{187}$

\footnotetext{
${ }^{186}<$ https://www.facebook.com/MemeConsciente> Acesso em 3/9/2014

${ }^{187}$ A imagem foi retirada da publicação do perfil privado de um amigo no Facebook.
} 
Figura 75 - Réplica do meme Marina Silva e Silas Malafaia..

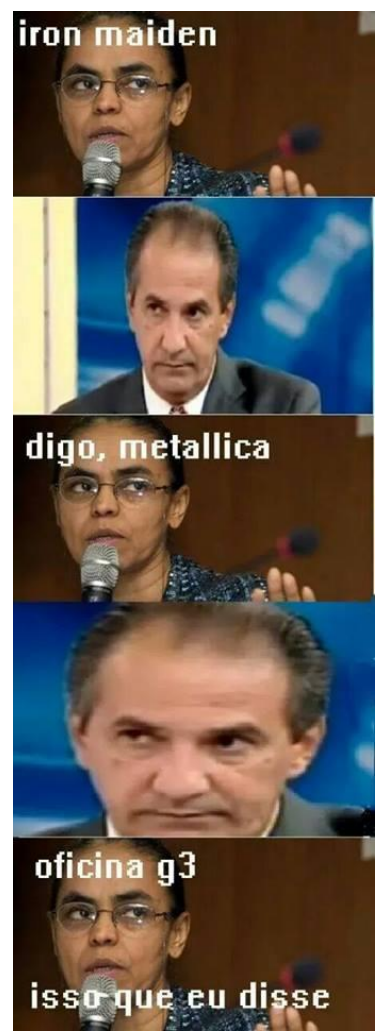

Fonte: theoldreader.com ${ }^{188}$

A postura de Marina, apresentada na mídia como ações de uma aparente falta de posicionamento, coerência e estabilidade, ganha no meme a sua dimensão crítica por meio de sua ridicularização. Retratam-se nessas recriações as atitudes hesitantes da candidata e a influência dos líderes religiosos (representados pela figura de Malafaia) nas suas decisões, cenário que no meme é transposto para situações banais. Reproduzir isso em uma nova roupagem, a das representações meméticas, é permitir que o riso revele uma outra face das informações que nos chegam, imprimindo um juízo em relação aos fatos. Essa é a projeção reflexiva de que nos fala Cortázar, Pirandello e Sodré e Paiva.

O humor, presente em nosso objeto de diferentes maneiras, portanto, é a arma que o romantismo grotesco nos deixou de herança para rir das desventuras do mundo, incluindo nelas os nossos próprios infortúnios, enquanto parte de uma coletividade, parte desse mesmo mundo. $\mathrm{O}$ riso humorístico, mais que suavizar nossa existência em meio a esses dramas, torna-se áspero, algo entre o trágico e o cômico, nos permitindo ter

\footnotetext{
${ }^{188}$ < https://theoldreader.com/profile/allanpatrick> Acesso em 3/9/2014
} 
outra apreciação dos valores, dos hábitos e da nossa inevitável humanidade, projetando nosso pensamento à crítica ou pelo menos a uma outra forma de reflexionar os fatos.

Nesse sentido, entendido a partir dos estudos dos autores analisados, se diferencia da comicidade por propor algo que vá além de um riso alegre: o riso no humor é por vezes incômodo, somando certa aspereza à alegria, e por outro lado é também de empatia e identificação. Tomando o humor como um tipo especial de riso, podemos entendê-lo como parte de um conjunto de manifestações mais amplo que seria a comicidade. Tanto o humor quanto o cômico, por conseguinte, estão em oposição à ideologia da seriedade: "a comicidade, em qualquer de suas formas de expressão, foi sempre desvalorizada em função da sobre-estimação que nossa cultura faz do sério. Nesse sentido, as formas do cômico contêm um valor de rebeldia e são intrinsecamente revolucionárias" (MENÉDEZ; CARIGNANO, 2007, p. 1).

Essa rebeldia do cômico, como vimos no riso carnavalesco, consiste em sua faculdade de viabilizar outra apreensão dos objetos, torná-los risíveis para vê-los desde um outro ângulo. O humor, assim, é uma herança do grotesco que, enquanto uma categoria estética que se fundamenta em uma visão cômica (risível) do real, representa "uma outra experiência de lucidez" que penetra no mundo, configurando-o de maneira distinta, "ao revés", como sustenta Bakhtin, revelando o que estava encoberto, invisível. Desse modo, o humor, como parte do grotesco, pode configurar-se como uma radiografia risonha do real, e por essa razão, descontrói frequentemente as obras criadas pelo idealismo cultural (SODRÉ e PAIVA, 2002, p. 60). Nos memes, essa desconstrução está no desmantelamento da sisudez das imagens jornalísticas, na dessacralização da áurea artística das obras de arte, na releitura esteticamente grosseira das produções profissionais do cinema e da TV, bem como das imagens amadoras cotidianas, que apesar de não serem sequer obras artísticas, muito menos parte de um ideal cultural, entram no jogo das recriações, possíveis pela linguagem do meme. 


\section{CONSIDERAÇÕES FINAIS}

Esta pesquisa buscou discutir o meme como uma linguagem da internet, esta entendida como um meio de comunicação, procurando definir alguns traços que configurariam as especificidades linguísticas de nosso objeto. Ao longo desse percurso, também debatemos sobre meio, cultura, linguagem, texto e compreensão, o que apontou caminhos para pensar o meme como uma linguagem da internet, bem como iluminou alguns pontos que merecem futuras reflexões.

O que nos surpreendeu, motivando esta investigação, foi a observação de certo padrão de comunicação nas interações via internet, uma generalidade que parecia se consolidar de tal maneira, que já possuía um nome conhecido e aceito não só por aqueles que se serviam desse modo de interagir e comunicar. Nossa inquietação se fomentou assim por uma lógica da surpresa, de que fala Nubiola (2001) a partir do pensamento de Peirce - na qual nossa admiração diante do fenômeno residiu não na percepção de uma irregularidade, senão de uma regularidade inesperada que se estabelecia. Apesar disso, tentamos não tratar o tema na euforia de uma novidade que permeia algumas discussões sobre manifestações culturais da internet, buscando entendê-lo a partir de categorias, movimentos, gêneros que já se manifestaram na cultura. A "novidade" estaria talvez na maneira e nas novas combinações com que esses elementos são retomados, por exemplo, a combinação específica que o meme faz de paródia e repetição, elementos que aparecem também em manifestações culturais como o teatro, a literatura, as artes plásticas, as séries de TV, os filmes, as novelas, entre outros. Nesse sentido, acreditamos que, ao mesmo tempo em que o meme pode ser tomado como uma novidade, ele é também a continuidade de certas conformações culturais já existentes.

Nosso processo de pesquisa começou, desse modo, por uma exploração etimológica, revisando a noção de meme de Richard Dawkins, que também se surpreendeu, de certa forma, com essa continuidade dos elementos da cultura no tempo, procurando entender a repetição no processo "transmissão" cultural, baseando-se na analogia entre gene e meme. Criticado por diversos autores e também seguido por muitos, o pensamento de Dawkins originou a memética, uma ciência que procura compreender a cultura como um processo evolutivo protagonizado pelo meme, a 
unidade cultural replicadora, que prolonga a sua existência a partir da sua reprodução por meio de cópias, "saltando de cérebro em cérebro".

Essa nossa passagem pela memética, incluindo as críticas a essa ciência, nos permitiu melhor compreender a origem do termo, além de inspirar alguns caminhos para pensar o meme como um fenômeno de linguagem. A revisão da teoria de Dawkins e de alguns de seus seguidores e críticos possibilitou também iluminar algumas relações do pensamento do etólogo com a semiótica, como quando comparamos o meme ao signo (Peirce) e o caldo cultural à semiosfera (Lotman). Essa discussão foi importante em nossa pesquisa tanto como um exercício filosófico, como também para compreender que aspectos faltavam à teoria de Dawkins para dar sentido ao fenômeno da internet. Reconhecemos, assim, que a associação do construto teórico do etólogo ao que estava ocorrendo nas práticas comunicacionais da internet não foi aleatória, pois há pontos em sua teoria que nos permitem entender os memes da internet. Contudo, essa linha de pensamento não dá conta de alguns fatores que transparecem nos memes, como o processo de compreensão, cuja elucidação nos parece essencial, em se tratando de um fenômeno que envolve comunicação e apreensão do mundo.

Esse nosso incômodo com a irrelevância que os processos de entendimento parecem ter para a memética tornaram-se evidentes também nas críticas que revisamos no presente trabalho, que aqui destacamos e procuramos ver por outros ângulos. Entre elas ressaltamos a desaprovação da imitação como único processo de aprendizagem cultural e a crítica à aparente ausência da ação humana nos processos de cultura, ambas revelando esse incômodo que tivemos. A respeito dessa última, pudemos ver que o entendimento dessa passividade dos sujeitos nos processos de transmissão cultural não é tão rigoroso, no sentido de que, se nossa mente é o ambiente ao qual o meme deve se adaptar, sobrevivem aqueles que são selecionados e passados adiante. Desse modo, podemos dizer que a memética reconhece a intencionalidade do sujeito de escolher os memes a serem transmitidos, entretanto, reforçamos que, ainda assim, ignora os processos de compreensão, pois está mais preocupada em tomar a cultura como evolução, a partir do ponto de vista do meme e não do sujeito.

Dawkins se refere, desse modo, a uma transmissão de cérebro para cérebro em vez de mente para mente, reflexão a partir da qual sugerimos duas ponderações. A primeira delas é que, nesse entendimento, o sujeito na cultura aparece apenas como um vetor, isto é, ele é o cérebro que irá abrigar as informações meméticas, e não aquele que experimenta a cultura, que entende, que infere, que interpreta o mundo. Inclusive, a 
relação entre esses sujeitos é ignorada, nada se diz acerca de uma partilha de conhecimentos ou de que tipos de interação ocorrem entre eles pelos memes, pois tratam-se apenas de suportes para essas unidades. A segunda ponderação é que, essa localização do meme no cérebro também indica uma aparente desconsideração ao que popõe Peirce como externalidade do pensamento: a ideia de que o meme, entendido de modo semelhante a um signo, não está na cabeça de um indivíduo, mas se manifesta em um trânsito de pensamentos, que também é externo. Contudo, os memeticistas parecem reconhecer isso de alguma forma, quando afirmam que os memes podem se abrigar em suportes materiais, o que nos concede indícios de que esses pensadores, de certa forma também entenderiam um aspecto de externalidade no fenômeno do meme, apesar de situá-los no cérebro.

É válido destacar nesse ponto que, ao associar o meme a uma ideia de signo, podemos incluir a sustentação que sentíamos falta na memética para compreender o fenômeno da internet com seus jogos de significação, isto é, podemos incluir a intelecção como parte do devir dos memes. A associação entre meme e signo nos permitiu, assim, repensar a questão da fidelidade da cópia, cuja discussão revelou a dificuldade em se definir os limites do que é uma réplica de um meme e o que deixa de ser, passando a consistir em outro meme, devido às possíveis transformações no decorrer das replicações. Sugerimos, assim, comparar a replicação à semiose, o que ensejou apreender essa variação entre uma cópia e outra como parte do crescimento do signo. Como mostra Ponzio (2008, p.165), a partir de Peirce, o signo não se repete, e a cada vez que se volta a usá-lo, um novo ato de semiose se configura.

A aproximação entre meme e signo também nos permitiu compreender que a analogia entre meme e gene é viável para entender a cultura como algo que ultrapassa a nossa existência. Dessa maneira, apesar das nossas restrições com a memética, acreditamos ser válida a interpretação de que "a vida" do meme é mais longa que a nossa. Assim, ele é, de certa maneira, autônomo, no sentido de não depender de determinado indivíduo, mas sim de muitos em seu devir, perpetuando, portanto, a sua existência nessa semiose ilimitada.

Nesse sentido, relacionamos também o construto de Dawkins à ideia de semiosfera de Lotman, contemplando os memes como entes que se auto-organizam de forma quase que independente, assim como a cultura, entendida como um sistema autoorganizador e auto-gerador. Desse modo, partindo de uma análise de Henn, pudemos comparar o caldo cultural com a semiosfera: assim como no caldo estariam dispersos os 
memes, na semiosfera estariam inseridos os textos, linguagens e códigos, sendo esses elementos dispersos - tanto no caldo cultural como na semiosfera - geradores de estruturalidade. Uma consideração a ser feita nessa comparação, contudo, é que, para Dawkins, a transmissão cultural é conservadora, enquanto a perspectiva da semiótica da cultura irá caracterizá-la como uma constante tensão entre conservação e mudança, entendendo o processo da cultura não como transmissão e sim como transformação dos textos. Desse modo, lançando o nosso olhar ao meme a partir da semiótica podemos vislumbrar que o meme é ao mesmo tempo regularidade com liberdade para a transformação, a (res)significação.

Revisitando Dawkins e procurando, assim, as pontes que ligam a memética ao que se configurou na internet, entendemos, nesta pesquisa, que o que motivou a apropriação do termo "meme" para referir-se ao fenômeno da web foi o fato de que tanto o meme de Dawkins quanto o da internet se davam na pluralidade de suas “cópias", incluindo certo grau de mutações nesse processo. Acreditamos, assim, que as ocorrências meméticas da internet, entendidas em aproximação aos memes de Dawkins, apresentam um padrão comum a todas elas: a repetição e a "mutação" - esta última compreendida no meme da internet como recriação - compondo um padrão que conecta todas essas ocorrências.

Foi então a percepção desse padrão que nos moveu a investigar o fenômeno, em um cenário em que distintas manifestações estavam sendo consideradas "um mesmo": um meme - de um conjunto de frases a modos de tirar de fotografia e publicá-las, a vídeos, a montagens e tantos outros - apresentando assim certa estrutura, uma regularidade. Dessa forma, procuramos entender o ordenamento que sustenta todas essas manifestações como um mesmo tipo de sistema de comunicação, tomando o fenômeno, a princípio por sua generalidade, como uma linguagem. Aliado a isso, também nos questionamos sobre a relação dessa linguagem com o meio. Nesse sentido, poderia ser o meme uma linguagem da internet? Como essa relação poderia ser entendida?

Buscar as respostas a essas questões demanda uma compreensão do que seria o próprio meio de comunicação. O que estávamos tomando como meio? O que faz de algo um meio de comunicação? As reflexões a partir de McLhuan e o desenvolvimento de alguns pontos do seu pensamento por Martino nos permitiram vislumbrar o meio para além da materialidade da manifestação da técnica. Podemos, assim, compreender o meio de comunicação como relação: a interação dos indivíduos com e pelo dispositivo 
técnico, de modo que um suporte, uma tecnologia como a internet, só se torna de fato um meio de comunicação quando é viabilizadora dessas relações, adquirindo assim a função de meio. Portanto, é a presença dos sujeitos em uma situação comunicativa que faz do suporte, da materialidade, um meio de comunicação - como um jornal que pode ser entendido como tal na presença do seu leitor, a TV na presença do seu espectador, o rádio, do seu ouvinte e assim por diante. Buscamos mostrar nessa investigação, assim, que é a mediação com uma mente interpretante que torna uma tecnologia um meio de comunicação.

Desse modo, tomamos o meio como uma manifestação da técnica, sendo assim uma extensão do homem, como propunha McLuhan. Contudo, para compreender o meio digital, nos detivemos na sugestão do autor canadense de que o meio seria uma extensão da consciência, e não de algum de nossos sentidos, noção que é alargada por Martino (2000) ao afirmar que os meios estendem nossa faculdade de comunicação, podendo assim ser entendidos como uma extensão da nossa consciência. Dessa maneira, esclarecemos a partir dos autores que, mais que conectados em uma analogia simbólica, meio de comunicação e consciência estão em uma continuidade ontológica, sendo ambos constituídos por signos. Relacionamos essa reflexão com o sinequismo de Peirce e o entendimento da externalidade da mente, isto é, a ideia de que a mente é um processo (semiose, um trânsito de pensamentos), não se localizando apenas no cérebro, possuindo aspecto interno e externo: " $\mathrm{Na}$ minha opinião é bem mais verdadeiro que os pensamentos de um escritor vivo estão em qualquer cópia impressa de seu livro do que estão em seu cérebro" (CP 7.634, tradução nossa ${ }^{189}$ ). Por conseguinte, o pensamento tem uma encarnação material e meio de comunicação e consciência estão em continuidade, de modo que podemos entender o meio como uma extensão da consciência.

Essa reflexão nos provoca também outra que merece atenção: retomando aqui McLuhan quando afirma que a inserção de um novo meio na matriz dos meios de comunicação traz mudanças de ordem social, cultural e cognitiva, poderíamos inferir inversamente que a nossa consciência pode ser entendida como uma extensão dos meios de comunicação, no sentido de que nossos modos de pensar e expressar esse pensamento também estão se transformando com a inserção da internet em nosso cotidiano. Essa ponderação está presente em Nicholas Carr (2010), que retoma os

\footnotetext{
189 "In my opinion it is much more true that the thoughts of a living writer are in any printed copy of his book than that they are in his brain"
} 
escritos de McLuhan e sugere que a internet possa estar mudando a maneira com pensamos. Ele sinaliza isso por meio de diversos exemplos e o ponto de partida para essas reflexões é a identificação de transformações em sua forma de leitura e a de alguns colegas, notando uma dificuldade de concentrar-se em textos longos, executando uma leitura fracionada e rápida:

\begin{abstract}
Como sugeria McLuhan, os meios não são apenas canais de informação. Proporcionam a matéria do pensamento, mas também modelam o processo do pensamento. E o que a Web parece estar fazendo é reduzir minha capacidade de concentração e contemplação. Estando online ou não, minha mente agora espera absorver informação da maneira que a $W e b$ a distribui: em um fluxo veloz de partículas. No passado eu era um mergulhador no mar das palavras. Agora deslizo pela superfície como um cara em um jet ski. (CAAR, 2010, p.6-7, tradução nossa ${ }^{190}$ )
\end{abstract}

Desse modo, não poderíamos presumir que essa forma fragmentada e veloz na maneira de pensar, que sugere Carr, não se reflete também na expressão por meio da linguagem do meme? Um modo pulverizado, instantâneo, e rápido de entendimento do mundo, o "fluxo veloz de partículas" de que fala o autor. Não poderíamos ver as réplicas das ocorrências meméticas assim, como estalos curtos de expressão a serem compreendidas em igual velocidade? Resgatando a ideia de gramática dos meios que vimos na introdução desta investigação e que estiveram nas discussões iniciais da pesquisa, talvez possamos entender essa forma de leitura como parte da gramática dos meios digitais, uma vez que, ao nosso ver, a ideia de gramática corresponde às características dos meios que influenciam os modos como eles são utilizados e como as mensagens são percebidas e recortadas. Essas articulações foram feitas a partir das leituras, contudo são ainda incipientes, não chegamos a desenvolvê-las. Nesse sentido, gostaríamos apenas de deixar o registro dessa reflexão nestas considerações finais.

Retomamos, assim, o ponto que abordávamos do meio como extensão da consciência, lembrando que esta está visceralmente ligada àquele, reproduzindo tecnicamente a sua função, como nos mostrou Martino. Tomando como base essa reflexão, procuramos estabelecer um diálogo entre a ideia de meio de comunicação e a de cultura, presente na semiótica de Lotman: como uma extensão da consciência, acreditamos que o meio pode ser entendido também como um dispositivo pensante, isto

\footnotetext{
190 “As McLuhan suggested, media aren't just channels or information. They supply the stuff of thought, but they also shape the process of thought. And what the Net seems to be doing is chipping away my capacity for concentration and contemplation. Whether I'm online or not, my mind now expects to take in information the way the Net distributes it: in a swiftly moving stream of particles. Once I was a scuba diver in the sea of words. Now I zip along the surface like a guy on a Jet Ski."
} 
é, um sistema que funciona como uma mente, dotada de memória, ações inteligentes (de interpretação e emissão de mensagens), formação de hábitos e linguagens. Desse modo, buscamos compreender esse espaço da mente (e que funciona como mente) que é o meio de comunicação como uma semiosfera, um ambiente de elementos semioticamente ecléticos do qual nós também fazemos parte. O meme é, portanto, uma linguagem que emerge das práticas nesse espaço, isto é, das relações de tradução, compactação, interpretação dos textos dispersos na semiosfera. Entender o meio como esse ambiente é, assim, o que nos permite conceber o meme como uma linguagem $d a$ internet. Nesse sentido, a web tomada como cultura, como esse dispositivo pensante, se configura como um ambiente semiótico, que torna a existência do meme como linguagem possível. Trata-se, portanto, na perspectiva da semiótica russa, de perceber o meio como um organismo vivo, de transformação de textos e não como um sistema de transmissão no qual destinador e destinatário são instâncias passivas, cérebros-suportes para informações (como acabam nos sugerindo as ideias de Dawkins, de certa maneira).

É preciso sublinhar nesse ponto da discussão sobre a internet como meio que abordar o meme como uma linguagem da internet não implica um "aprisionamento" do meme ao meio. Com isso intencionamos denotar que o fenômeno acontece na rede e que nesta pesquisa entendemos algumas de suas particularidades pelos modos de circulação no "ambiente virtual", mas isso não significa dizer que o meme não está "fora da internet". A própria noção de continuidade não nos permite afirmar que o meme só aconteça na internet. Assim, se o meme é uma linguagem, é também uma forma de pensamento, uma forma de entendimento do mundo, seja "dentro" ou "fora" da internet, portanto não se restringe ao ambiente online. Por conseguinte, não faria sentido tratar a cultura da internet como um "ambiente virtual" que está desconectado do "mundo real", que é uma outra realidade. Com o termo "linguagem da internet" não queremos dizer que o meme é uma "linguagem na internet".

Essa mesma compreensão é válida para afirmar que tratar de uma cultura da internet não significa torna-la alheia à cultura de outros meios. Os meios não são estanques e nem estão isolados um dos outros (MARTINO, 2013 ${ }^{191}$ ), o golpe que inicia um meme pode vir de um elemento da cultura de massa, assim como o que circula na rede também migra para a televisão, por exemplo. Desse modo, quando tratamos o meme como parte da internet, não o suporte internet, mas como o ambiente cultural e

\footnotetext{
${ }^{191}$ Informação dada na aula de Teorias da Comunicação ministrada no dia 16 de julho de 2013.
} 
semiótico (a extensão da consciência), não intencionamos torná-lo exclusividade desse meio - isto é, existente somente nesse meio - tampouco a cultura que se estabelece. Apenas reconhecemos que é uma linguagem cuja configuração também se apoia em interações mediadas pela web e cujo entendimento das mensagens depende em partes das experiências comunicativas naquele meio. Destacamos, desse modo, que a cultura se trata de uma esfera que rodeia o indivíduo e que faz parte dele -"separar o homem do espaço das línguas, dos signos, dos símbolos é tão impossível quanto arrancar-lhe a pele que o cobre" (LOZANO, 1995, tradução nossa ${ }^{192}$ ) - ao mesmo tempo que perpassa e encontra-se com outras esferas culturais, pois como vimos, as fronteiras da semiosfera são penetráveis, estão em contato com o que lhe é externo. Nesse sentido, uma cultura da internet, por ser parte de um espaço da mente, algo que nos permite dar sentido ao mundo, não está somente na internet, pois o que vemos circular na web são manifestações da consciência. Dessa forma, consideramos que não podemos restringir a existência do fenômeno ao meio, mas também não podemos apagar totalmente a internet de algo que se estabelece como meme da internet.

Outra questão discutida foi a da relação paradoxal da linguagem e da cultura, suscitada a partir do entendimento de Lotman de que a semiosfera seria algo que precede a linguagem e a semiose. Entendemos, nesta investigação, que procurar estabelecer o que teria surgido primeiro, entre essas duas instâncias, seria uma tarefa impossível, pois há uma interdependência entre cultura e linguagem. Desse modo, aceitando a hipótese de que o meme é uma linguagem, acompanhando esta ideia está também uma noção de "cultura dos memes" (uma semiosfera). O paradoxo que se estabelece não chega, entretanto, a configurar uma contradição, no sentido de que linguagem gera cultura e vice-versa, isto é, a cultura depende de processos como a comunicação, a semiose e a linguagem para ter existência, bem como só sobrevive a partir desses processos, o que nos permite apreender a relação meme e cultura de memes como uma sistema que se retroalimenta e que é também auto-gerativo e autoorganizador. Pensar os memes nessa discussão nos aponta maneiras de entender uma de nossas questões iniciais: a de que um conjunto de manifestações aparentemente díspares estariam, na realidade, organizadas de maneira similar, de modo que poderíamos chama-las todas de meme. Possuiriam, então, uma regularidade, suas "regras gramaticais".

\footnotetext{
192،"Separar al hombre del espacio de las lenguas, de los signos, de los símbolos es tan imposible como arrancarle la piel que lo cubre."
} 
Essa regularidade, juntamente com seu caráter social e público e sua propriedade de dar sentido, ou seja, conceber o mundo de um modo particular, foram os três aspectos que destacamos para entender o meme como linguagem - aspectos que se implicam mutuamente, sendo esta separação adotada apenas instrumentalmente, facilitando nossa visão do objeto. Para abordar tais fatores, recorremos a Peirce e à teoria geral do signo, o que nos permite entender o fenômeno por sua terceiridade, que junto com a primeiridade e a secundidade compõem as três categorias pensadas pelo filósofo americano para compreender o faneron. Como vimos, as três categorias estão presentes no meme, contudo ressaltamos a terceira, que diz respeito aos fenômenos que envolvem pensamento, conhecimento regularidade, coordenação, comunicação, representação, nos permitindo entender o meme como um "centro-organizador" (um núcleo na semiosfera), que apresenta algo de essencial que nos autoriza compreender determinada manifestação como um meme. Essa "essência", entretanto, não deve ser tomada como inerente às ocorrências, mas sim como algo que as conecta. A generalidade do meme pode ser entendida assim como relação: há um "parentesco" entre determinadas manifestações e é essa similaridade entre entes atuais que conforma o que compreendemos como meme.

Nesse sentido, o meme cria padrões, que são as suas "regras gramaticais". Ao criar esses padrões, podemos adotar certas atitudes em relação a fatos futuros, a outros entes atuais, de modo que a terceiridade necessita de um tempo para "sedimentar-se". Os fenômenos de terceiridade são, assim, não apenas contínuos, mas também não imediatos, no sentido de que as regras não podem ser tecidas em um único instante, mas sim em um processo. O meme é, desse modo, lei (legi-signo), estabelecendo hábitos, isto é, uma tendência a atuar de determinada forma (a construir mensagens de determinada forma), uma disposição que se configura pela múltipla reiteração. Partindo de Peirce, também podemos, assim, tornar clara a nossa indagação de como manifestações aparentemente diferentes estavam sendo entendidas de um mesmo modo, isto é, sendo tomadas como meme. Nesta investigação, a articulação que fizemos com a ideia de legi-signo nos permite compreender cada ocorrência memética como um ente atual compondo e sendo ordenada concomitantemente por uma lei que a interliga a outras ocorrências semelhantes, prevendo outros eventos que podem ser tomados como meme.

As regras que emergem nesse processo, contudo, não são rígidas e aqui podemos dialogar com o segundo Wittgenstein e os jogos de linguagem - uma pluralidade de 
usos que pouco a pouco vão configurando as normas e determinando que proferimentos (novos usos) que tem sentido em um contexto ou não. Como nos mostrou o autor austríaco, essa amálgama de usos particulares não é fixa - algumas envelhecem e podem ser esquecidas, enquanto outras podem até mesmo renascer - nada é rígido ou dado para sempre.

O meme, assim, estabelece seus jogos que consistem nos usos intencionais dos quais emergem os significados que essa linguagem pode dar para os objetos (a fotografia, o anuncio, o evento, a frase entre outros, que deu origem a um meme), bem como as regras que vão configurar uma manifestação como meme, que nesta investigação apontamos ser a repetição e a paródia. Entendemos, assim, que nos jogos de linguagem do meme, há sempre algo irrepetível, contextual e algo que se repete, uma regularidade, isto é, as regras do jogo. São nos jogos que algo interpretado e expressado nessa linguagem ganha um sentido e são esses mesmos jogos nos permitem entender uma manifestação como meme e não como outra linguagem, ou seja, permite o reconhecimento de suas normas. Pensando a partir de Wittgenstein, assim, sugerimos que saber jogar, isto é, saber comunicar-se por um meme, é saber agir de acordo com suas regras: uma ação que é pública e que implica um conhecimento partilhado, sendo também dependente de uma competência adquirida no próprio jogo de linguagem e que pode mostrar novos casos que contam como exemplo de seguir essas regras. Nesse sentido, podemos dizer que o que estabiliza as práticas do meme como linguagem é a concordância na interpretação das regras. Essa discussão foi importante para nos mostrar o que estaríamos tomando como "norma", como regularidade em certas manifestações culturais da web, o que nos reenvia a outra de nossas observações preliminares: a de que os memes sempre repetiam algo ao passo que permitiam uma interferência do usuário, uma ressignificação. Nesse sentido, pensando a partir de Wittgenstein, compreendemos que a estabilidade na prática do meme está na aceitação coletiva de que repetição com apropriação e recriação (paródia) configuram um meme.

Além do seguimento das regras, a analogia de Wittgenstein entre linguagem e jogo, evidencia outro aspecto desta noção presente na linguagem do meme: seu caráter de divertimento, o jogo como uma atividade prazerosa. Desse modo, o meme como linguagem, mas também como jogo, concede liberdade aos seus falantes, nos limites das regras. Essa margem para a recriação no limiar do reconhecível, que caracteriza seu aspecto paródico, entretém, convida a participar da dinâmica da ocorrência memética, ao passo que também envolve o destinatário no jogo da ressignificação. Comunicar e 
apreender o mundo pela linguagem do meme, nesse sentido, é mais que um modo de expressão, é também a possibilidade do lúdico.

No percurso desta investigação, tornou-se claro também que a linguagem é um tipo de jogo que não se joga sozinho, pois é comunitária, pública, partilhável e transmissível, mesmo havendo certas circunstâncias de uso que acreditamos serem bastante particulares. Desse modo, expusemos que o sentido de uma palavra ou de um texto (verbal ou não), depende de fatores extralinguísticos para se corporificar, sendo esses fatores compartilhados de maneira que podemos afirmar que a linguagem sempre pressupõe um outro. Os jogos de linguagem do meme envolvem assim duas perspectivas: a de um sujeito emissor e a de um sujeito receptor e, como vimos, mesmo que nos comuniquemos sozinhos essa relação irá existir.

$\mathrm{O}$ fato de os jogos de linguagem pressuporem, portanto, uma partilha nos conduz ao destaque de duas noções complementares que acompanham o entendimento da linguagem: a de comunidade e a de contexto cultural, às quais chegamos fazendo algumas inferências a partir da noção de forma de vida de Wittgenstein. Como vimos, dada a impossibilidade de uma linguagem privada, devemos entender que a linguagem e o pensamento não se situam no indivíduo, mas sim, compõem uma forma de vida, isto é uma formação social e cultural, na qual os indivíduos partilhando referencias comuns estão inseridos. Desse modo, podemos afirmar que há um conjunto de práticas, convenções e conhecimentos no qual o meme está imerso e a partir do qual são atribuídos os critérios de sentido de seus jogos de linguagem. Dessa maneira, essa partilha que mencionamos anteriormente implica tanto os outros sujeitos com quem partilhamos algo (comunidade) e esse algo que é partilhado (um contexto, uma memória comum). Esses dois aspectos abstraídos a partir da noção de forma de vida nos serviram de base para lançar luz às dinâmicas de compreensão (e incompreensão) dos textos na linguagem do meme. Essa reflexão a partir de Wittgenstein nos reenviou à semiosfera de Lotman, que se caracteriza também como o contexto cultural em que um texto é apreendido. Pensada em termos de uma espacialidade, é o ambiente no interior do qual encontram-se diversos textos (que compõem o contexto de algo a ser interpretado) e os indivíduos com os seus mundos semióticos, partilhando de uma memória comum (que nos leva ao entendimento da comunidade). Além de sua espacialidade, a semiosfera também foi avaliada em termos de uma temporalidade, que permite conferir um sentido e não outro em determinado momento dialógico concreto, isto é, uma situação comunicativa que envolve emissão e recepção de memes. Separamos em dois 
momentos, assim, mais uma vez de forma a facilitar a nossa própria compreensão das dinâmicas do meme, a comunicação e a apreensão do mundo a partir dessa linguagem: 1) a produção (proferimento) de um meme e 2) a sua recepção, ambos podendo ser entendidos na continuidade da semiose.

Ao discutir o meme em articulação com a noção de semiose, podemos compreender a sua criação como um ato de leitura do mundo. Pela linguagem do meme, com o seu modo particular de dar forma e manifestar o pensamento, determinada informação (um texto base) é tomada como o objeto que se dá a conhecer pela linguagem do meme (signo), gerando leituras acerca desse objeto (interpretantes). A semiose é, assim, ação do signo, sua capacidade de significar, de gerar outros signos, isto é, signos interpretantes, pois, faz parte da natureza do signo sua capacidade de crescer - esse crescimento deve ser entendido como essa possibilidade de encadear outros signos, sendo a sua identidade dada nesse jogo de remissões. Desse modo, o conceito de semiose nos serviu para a compreensão de que o meme configura uma maneira de acessar o real que se dá em uma cadeia de leituras acerca de um objeto. Esse nosso entendimento pôde ser detalhado com base na teoria geral dos signos, compreendendo a possibilidade que determinada informação que nos chega tem de significar como o interpretante imediato, isto é, indício de interpretabilidade inerente ao signo. Essa possibilidade se torna atual quando surge o interpretante dinâmico, que em nosso trajeto investigativo tomamos como as réplicas individuais de cada ocorrência memética, isto é, um ato particular de interpretação daquela informação. Por fim, mencionamos o interpretante final, como uma tendência que os interpretantes dinâmicos seguem, não sendo tomado como uma compreensão final e absoluta de algo, mas como um limite ideal, aproximável e inatingível. Pensar o meme a partir dos interpretantes nos permite vislumbrar essa linguagem como a nossa forma de conceber o mundo, de dar sentido a ele, uma vez que uma série de réplicas enseja a compreensão coletiva de algo nos modos da linguagem do meme. Sinalizamos aqui o aspecto que acreditávamos faltar à memética e que a perspectiva semiótica nos permitiu compreender: o processo de entendimento de algo mediado pelos memes. O uso da linguagem - ou seja, a "replicação" dos memes no caldo cultural - é, nesse sentido, mais que uma simples transmissão cérebro a cérebro. É uma forma de conceber algo, de entender o que nos cerca, além de configurar um modo de expressão.

Cada conjunto aberto de réplicas, que chamamos de ocorrência memética, se estabelece, assim, como uma semiose manifesta, dando-se na sucessão de leituras acerca 
de uma imagem, um evento, um vídeo entre outros. As réplicas, em continuidade, assumem o papel de objeto no processo de sua recepção, determinando um terceiro, isto é, um signo interpretante que configura o entendimento dessa réplica (e de uma ocorrência memética como um todo). Nesse sentido, tomando as réplicas como textos (ou signos, num entendimento peirceano), podemos dizer que os memes criados serão interpretados no interior de uma semiosfera, no contato com outros textos (outros signos na processualidade da semiose), delimitados por uma temporalidade, fatores que irão determinar sentidos possíveis. Como vimos, essa relação é dialógica, diferente de uma simples transmissão. O leitor se situa em relação ao texto em uma compreensão responsiva, buscando na sua experiência, em seu conhecimento prévio, as "respostas" para o diálogo estabelecido com o texto no ato de sua interpretação. Nessa dinâmica, uma mente se põe em relação a um objeto de maneira que, por mais que alguém possa dizer que "não entendeu" um meme, essa incompreensão é uma forma de entendimento, visto que há a presença de um interpretante. A comunidade, desse modo, seria o conjunto de sujeitos que lê o texto "da mesma maneira", ou pelo menos de modo similar, os sujeitos que estão "dentro" da mesma semiosfera. Essa discussão teve, assim, sua importância na pesquisa, ao nos permitir levantar alguns fatores a serem considerados em uma situação comunicativa: o contexto cultural, a temporalidade e a memória. Desse modo, a linguagem do meme estabelece jogos que envolvem uma articulação entre suas regras e um tempo-espaço onde estão indivíduos-coletivos, compondo um cenário comunicacional.

Assim, como procuramos mostrar, cada meme se configura como uma cadeia de interpretantes dinâmicos que se manifestam. Essa cadeia de signos pode ser entendida como um conjunto de leituras que têm um modo particular de se estabelecer, que fazem da linguagem do meme uma forma específica de conhecer e representar o mundo. Nessa pesquisa, delineamos que essa especificidade está na articulação de repetição e paródia e suas inter-relações com categorias secundárias que nos auxiliam a avaliar o que entendemos hoje como meme da internet. Dentre estas, destacamos o excesso, o exagero, o absurdo e a comicidade (pensada como cômico e como humor). O que procuramos tornar claro nesta investigação é que todas elas têm em comum, tanto as primárias como as secundárias, um aspecto de forçar os limites de um sistema, por vezes até mesmo ultrapassando esses limites.

Na repetição, por exemplo, essa tendência ao confim está numa experimentação do excesso pela quantidade de "cópias" e na cadência acelerada da produção dessas 
cópias que, junto com a paródia, permitem que façamos algo sair de sua normalidade nesse desenfreamento da criação de réplicas. Essa dinâmica chega a um ápice e depois sofre um declínio, caracterizando certa instantaneidade do meme. Essa queda nas produções não configura, contudo, o esgotamento do meme, este permanece sempre em aberto, podendo até mesmo ser retomado. Ressaltamos também que, nesse processo de reiteração, o meme não está não está simplesmente copiando, reproduzindo, mas sim conformando cópias não idênticas. Ao contrário do gene, se revisitamos aqui a analogia de Dawkins, no meme, pensando especialmente no meme da internet, a mutação é necessária, ainda que haja sempre entre as cópias um elemento em comum que as une.

Essas relações de diferenciação e identidade entre as réplicas revelam, assim, o aspecto paródico dessa linguagem, que nas nossas inquietações iniciais foi identificado como o fato de o meme repetir algo, mas também permitir uma interferência do usuário. Desse modo, uma vez que as cópias nas ocorrências meméticas operam por apropriação e recriação, implica nesse processo a criação de um texto a partir de outro que já está estabelecido, havendo nessa nova concepção uma relação de semelhança e diferença entre o texto final (paródico) e o texto de origem (parodiado). Nesse sentido, frisamos que o meme, entendido em sua condição paródica, possui uma natureza irônica. Diferentemente da ironia na linguagem verbal, na qual há uma sobreposição de contextos semânticos, na paródia encontramos uma sobreposição de contextos textuais, marcando um contraste, isto é, a presença de dois ou mais textos em uma única "obra" (em uma réplica de um meme, na nossa análise). Essa discussão, dessa maneira, foi essencial na pesquisa para evidenciar que, por apresentar essa natureza irônica, o meme acaba criando um tensionamento, visto que ele é a síntese de heterogeneidades textuais. Dessa forma, o meme é, ao mesmo tempo, uma ruptura com o texto parodiado e uma continuidade sua, o que o caracteriza como uma "linguagem excêntrica" - uma linguagem que age nos limites de um sistema ordenado, mas sem ameaçar a sua regularidade.

A excentricidade, dado o caráter paródico do meme, configura, desse modo, uma lei de ação em que certa transgressão está prevista, sendo esse rompimento com a ordem na realidade uma regra. A transgressão, contudo, tem um limite, residindo nesse ponto a tensão: esse limite consiste em transgredir desde que se mantenha a reconhecibilidade do texto parodiado. Vimos, assim, que esse efeito paródico do meme, dada a necessidade desse grau de reconhecimento, é relativo a um leitor que deve captar a relação intertextual apresentada. Ressaltamos também o caráter dialógico desse 
intertexto, que, por se apropriar e não simplesmente imitar, acrescenta algo ao texto parodiado, situando-o em um diálogo de contextos diferentes de produção: o seu contexto inicial e o do novo texto, o paródico. Essa discussão acerca da apropriação também oportunizou levantar a questão da autoria que, no meme, aparenta ser irrelevante, posto que, por mais que possamos definir um autor para uma criação, essa criação só se torna meme quando desencadeia réplicas. Nesse sentido, entendemos que algo só é meme na profusão de suas "cópias", sendo assim um processo que envolve uma coletividade. Em termos de autoria, esta seria, portanto, pulverizada, não determinada: um meme não é de um autor ou de outro, ele é "da internet".

Relembramos aqui também, um debate que nos pareceu interessante de se levantar acerca das especificidades do meme que foi a discussão sobre o risível nessas manifestações. Vimos que aquela tensão que emerge das novas relações textuais proporcionadas pelo meme pode gerar o riso que, como elucidado, no caso de nosso objeto, é um efeito possível de um entendimento, mas não necessário. É certo, portanto, que nem todas as ocorrências meméticas provocarão o riso de determinado leitor, pois o risível está como resultado dos arranjos textuais que se estabelecem em uma semiosfera. Contudo, nesta investigação, nossas inferências nos conduziram a entender o cômico não apenas como esse efeito viável, mas também como um caminho possível na concepção do mundo por essa linguagem. Nesse sentido, reflexionando sobre a criação de um meme, poderíamos afirmar que a relação entre interpretante e objeto, pensamento e mundo, por assim dizer, se constitui de modo risível no meme, no sentido de uma "carnavalização" das informações. Entendemos que essa linguagem torna determinada realidade inteligível, assim, pela ótica do riso, reconfigurando textos e concepções já estabelecidas, sérias ou dentro de uma normalidade. Procuramos lançar luz, por conseguinte, à maneira que o meme se forma em comparação a uma lógica abdutiva, no sentido de que a carnavalização opera na quebra das expectativas, na associação antes impensada de ideias. Interpretamos, assim, o conceito de carnavalização que Bakhtin estabelece para a compreensão da literatura, como um método que, na linguagem do meme, nos permite a contemplação do mundo como possível, aberto, em pleno movimento de crescimento semiótico.

Assim, o meme se dá sempre na repetição, que reconfigura e reconfigura e reconfigura inúmeras vezes uma informação, consistindo em uma gama de recriações (uma série de réplicas), baseadas na associação de elementos heterogêneos, na exageração, na absurdidade, no que há de insólito, que pode resultar no escarnecimento 
de alguém ou de uma situação, na percepção de um novo ângulo de contemplação, em um riso trágico ou pura e simplesmente prazeroso. Podemos entender, portanto, as redes sociais e os fóruns ${ }^{193}$, onde os memes são gerados e partilhados, como a praça pública, no sentido de ser o ponto de encontro para esse riso coletivo e a celebração, não do carnaval, mas da carnavalização. Um ambiente no qual torna-se possível a dessacralização não só no sentido bíblico, como poderíamos pensar em uma certa dessacralização do próprio Jesus no meme Ecce Mono, mas no sentido de uma "profanação geral", que tira do pedestal e coloca em outra situação os representantes políticos, os ídolos da música, da televisão e do cinema e por vezes nós mesmos, nos permitindo admirá-los pelo estranhamento, vendo-os de outro lugar, deformando-os.

Selecionamos, assim, algumas categorias de análise que nos permitiram entender como se configuram a linguagem do meme e sua cultura. Contudo, no decorrer da pesquisa identificamos que alguns aspectos dessa cultura nos permitiriam estabelecer outras duas categorias, das quais nos aproximamos timidamente no decorrer do último capítulo e que poderiam ser incorporadas em um estudo futuro: seriam elas o escárnio e o disforme. Esta segunda surgiu das ponderações feitas a partir da estética do grotesco que nos ensejou a entender o meme como parte de uma cultura que se opõe a outra dominante, a cultura "oficial” institucionalizada dos veículos de comunicação. Vislumbramos aqui, assim, uma possível aproximação com o grotesco, cujas imagens conservavam uma "natureza original", parecendo disformes, monstruosas, horrendas, "se consideradas do ponto de vista da estética "clássica", isto é, da estética da vida cotidiana preestabelecida e completa" (BAKHTIN, 1987, p.22). A "natureza original" do meme estaria em sua estética trash, deliberadamente tosca, na qual a apropriação paródica por vezes deixa nas imagens as marcas de sua gênese. Trata-se de um descuido proposital, uma intenção em ser disforme, caricatural e escrachado, o que também se insere na lógica da apropriação e do riso.

Por fim, chegamos à conclusão desta pesquisa, que, movida pela inquietação de dar sentido ao potencialmente infinito processo de (res)significação do meme, procurou compreendê-lo como linguagem da internet e, como tal, também uma forma de

\footnotetext{
${ }^{193}$ Reconhecemos que nesses espaços também transitam outras linguagens que não os memes, como o jornalismo, a publicidade, e até mesmo a partilha da vida pessoal de seus integrantes em uma dissolução do espaço público e privado. Diferente do carnaval na praça pública da Idade Média também, momento no qual havia o afrouxamento das hierarquias, quando povo e representantes de poder eram colocados praticamente no mesmo patamar, nas redes sociais especialmente, as hierarquias persistem. Nossa comparação, então, vale para ressaltar principalmente o aspecto de atmosfera propícia para a interação social e o "riso coletivo"que se dá tanto no ambiente da praça, como no das redes e fóruns quando nestes transitam os memes.
} 
pensamento. As respostas que procuramos inicialmente para entender a ressignificação, o potencial de sentido das informações e a conexão entre as mais variadas manifestações que se conformavam na internet não foram encontradas em Dawkins, porém ali estavam novas provocações que nos permitiram avançar na discussão do tema. Nesse sentido, o meme, originalmente pensado pelo etólogo, configura hoje, no ambiente da internet (e também fora dele), uma forma de construir o pensamento - uma forma e não outra - apresentando, assim, suas particularidades, determinadas pela reiteração de seus usos, delineadas em partes por características do meio de comunicação. Contemplar o meme, portanto, nos permitiu entender o meio como um dispositivo pensante, reconhecendo que a informação, da mais séria à mais banal, se transforma nas práticas de expressão, de modo que podemos entender o meme na cultura como um processo, uma dinâmica de crescimento semiótico. Dessa forma, mais que uma brincadeira em que juntamos uma imagem a outra, em que colocamos uma legenda para uma fotografia ou que editamos um vídeo, o meme opera dentro de uma lógica, configurando um dizer sobre o mundo.

Acreditamos, assim, que esta investigação nos possibilitou compreender responsivamente o que nos propomos inicialmente a entender, avançando no conhecimento daquilo que estamos chamando de memes da internet. Reconhecemos, por fim, que essa mesma investigação pode ser tomada como um signo e, como tal, cremos que o trabalho permanece em aberto, disponível a colocar-se em relação a outros signos interpretantes, ensejando novos caminhos inferenciais e interpretativos, dando continuidade a algumas reflexões que foram propostas aqui acerca do meme, do meio, da cultura e da linguagem. 


\section{REFERÊNCIAS BIBLIOGRÁFICAS}

ALBERTI, Verena. O riso no pensamento do século $X X$. In: O riso e o risível na história do pensamento. Rio de Janeiro: Jorge Zahar Editor, 2002, p.11-38.

. Riso e "entendimento" nos séculos XVIII e XIX. In: O riso e o risível na história do pensamento. Rio de Janeiro: Jorge Zahar Editor, 2002, p.11-38.

ÁLVAREZ, Larissa Guerrero. La subjetividad semiótica en Charles S. Peirce. Conferência dada no Seminario de profesores de la facultad de Filosofía Universidad Panamericana campus México. Disponível em < https://www.academia.edu/1665195/La_subjetividad_semi\%C3\%B3tica_en_Charles_S. _Peirce> acesso em 25/11/2014.

AMARAL, Adriana. Redes sociais, linguagem e disputas simbólicas. In: Revista Eletrônica de Jornalismo Científico, 2011. Disponível em < http://www.comciencia.br/comciencia/?section=8\&edicao=70\&id=878> acesso em 11 de agosto de 2011.

ARÁN, Olga P. Juri Lotman: actualidad de un pensamiento sobre la cultura. Escritos, Revista del Centro de Ciencias del Lenguaje, n.24, pp. 47-70, jul./dez. 2001.

ARMENGOL, Guillermo. Daniel Dennett, Memes and Religion: Reasons for the Historical Persistence of Religion. In: Pensamiento, v. 63, n. 238, p. 815-819. 2007.

BAKHTIN, Mikhail (V.N. VOLOCHÍNOV). Estudo das ideologias e filosofia da linguagem. In: Marxismo e Filosofia da Linguagem. São Paulo: Hucitec, 1986, p. 159-198.

Tema e significação na língua. In: Marxismo e Filosofia da Linguagem. São Paulo: Hucitec, 1986, p. 128-136.

BAKHTIN, Mikhail. A cultura popular na Idade Média e no Renascimento: o contexto de François Rabelais. São Paulo: Hucitec; Brasíla: Editora da Universidade de Brasília, 1987.

BARBOSA, Rodrigo Miranda. A internet como meio de comunicação a partir dos estudos da Teoria do Meio. 2010. 173f. Dissertação (Mestrado em Comunicação) Programa de Pós-Graduação em Comunicação da Universidade de Brasília, Brasília. 2010.

BARICHELLO, Eugenia Maria Mariano da Rocha; OLIVEIRA, Cristiane Cleveston de. O Marketing viral como estratégia publicitária nas novas ambiências midiáticas. In: Em Questão, Porto Alegre, v. 16, n. 1, p. 29-44, jan./jun. 2010.

BARRENA, Sara F. Los hábitos y el crecimiento: una perspectiva Peirceana. Razon y Palabra. México, n. 21, fev./abr. 2001. 
BARROS, Diana Luz Pessoa de. Contribuições de Bakhtin às teorias do texto e do discurso. In: FARACO, Calos Alberto; TEZZA, Cristovão; CASTRO, Gilberto de (Org.). Diálogos com Bakhtin. Curitiba: Editora UFPR, 1996, p. 21-42.

BAUCKHAGE, Christian. Insights into Internet Memes. Trabalho apresentado em Fifth International AAAI Conference on Weblogs and Social Media, Barcelona, 2011.

BECKO, Larissa Tamborindenguy; MAIA, Diego Pereira da; PIENIZ, Mônica. Os Processos de Identificação e Representação no Cartum: Análise das Tirinhas de "Memes" da Internet. Trabalho apresentado no XIII Congresso de Ciências da Comunicação na Região Sul, Chapecó, 2012.

BEN-PORAT, Ziva. Method in Madness: Notes on the Structure of Parody, Based on MAD TV Satires. Poetics Today, v. 1, n. 1/2, Special Issue: Literature, Interpretation, Communication, p. 245-272. 1979.

BEUCHOT, Mauricio. Las categorías ontológicas en Peirce. Razon y Palabra. México, n. 21, fev./abr. 2001.

BLACKMORE, Susan. Three Problems with Memes. In: The Meme Machine. Oxford: Oxford University Press, 1999.

BUCHEL, Branislav. Internet Memes as Means of Communication. Brno, 2012. 73f. Dissertação de mestrado - Faculdade de Estudos Sociais, Departamento de Sociologia de Masaryk University, Brno, 2012.

BURGESS, Jean. 'All Your Chocolate Rain Are Belong to Us?' Viral Video, YouTube and the Dynamics of Participatory Culture. In: Video Vortex Reader: Responses to YouTube. Amsterdam: Institute of Network Cultures, 2008, p. 101-109.

CALABRESE, Omar. Ritmo y repetición. In: La Era Neobarroca. Madrid: Catedra, 1999, p.44-63.

Límite y excesso. In: La Era Neobarroca. Madrid: Catedra, 1999, p. 64-83.

CALLOIS, Roger. Definição do jogo. In: Jogos e os homens: a máscara e a vertigem. Lisboa: Cotovia, 1990, p. 23-30.

CARACCIOLO, Paola Maira Gomes; PENNER,Tomaz Affonso; FILHO, Otacílio Amaral. Dos bordões aos memes: Uma análise sobre o papel da mídia na construção e apropriação de novas formas de linguagem. Trabalho apresentado no XXXIV Congresso Brasileiro de Ciências da Comunicação, Recife, 2011.

CARPENTER, Edmund. As Novas Linguagens. In: CARPENTER, Edmund; MCLUHAN, Marshall. Revolução na Comunicação. Rio de Janeiro: Zahar Editores, 1971, p.197-217. 
CARR, Nicholas. In: The Shallows - How the internet is changing the way we read, think and remember. Londres: Atlantic Books, 2010.

CHEN, Carl. The Creation and Meaning of Internet Memes in 4chan: Popular Internet Culture in the Age of Online Digital Reproduction. Habitus. New Haven, Yale University, Primavera, 2012.

CORTÁZAR, Julio. Quinta clase. Musicalidad y humor em la literatura. In: Julio Cortázar. Clases de literatura. Buenos Aires: Prisa Ediciones, 2013, p.149-180.

CRESPO, Bruna dos Anjos da Costa; KAESER, Letícia Macedo. Gêneros textuais e ensino: uma perspectiva bakhtiniana da linguagem. Disponível em $<$ http://eebaeducacao.blogspot.com.br/2011/10/bruna-dos-anjos-da-costa-crespoleticia.html> Acesso 24/1/2015.

DALL'AGNOL, Darlei. Natural ou Transcendental: sobre o conceito Lebensform em Wittgenstein e suas implicações para a ética. Rev. Filos., Aurora, Curitiba, v. 21, n. 29, p. 277-295, jul./dez. 2009.

A vida e a obra de Ludwig Witgenstein. In: Wittgenstein em retrospectiva. Florianópolis: Editora da UFSC, 2012, p.9-47.

DAWKINS, Richard. O gene Egoísta. São Paulo: Companhia das Letras, 2007.

DEELY, John. Semiose: o objeto da investigação semiótica. In: Semiótica Básica. São Paulo: Ática, 1990, p.41-51.

Introdução à semiótica: história e doutrina. Lisboa: Fundação Calouste Gulbekian, 1995.

DEUS, Andreia Morais de. A Estética do Grotesco no filme "Um Cão Andaluz". Artigo apresentado ao Instituto de Filosofia e Teologia de Goiás como requisito para aprovação na especialização em Filosofia da Arte. Goiânia, 2010.

DUTRA, Delamar José Volpato. Habermas e Wittgenstein: uma teoria dos jogos de linguagem. In: Wittgenstein em retrospectiva. Florianópolis: Editora da UFSC, 2012, p.219-229.

EDMONDS, Bruce. The revealed poverty of the gene-meme analogy - why memetics per se has failed to produce substantive results. Journal of Memetics: Evolutionary Models of Information Transmission. v. 9, edição final. 2005.

FARACO, Alberto Carlos; CASTRO, Gilberto de; TEZZA, Cristovão. Apresentação. In:___ (org.). Diálogos com Bakhtin. Curitiba: Editora UFPR, 1996, p. 7-20.

FERRARA, Lucrécia D'Alessio. Entre a Comunicação e a Semiótica, o Mundo.

Ghrebh- Revista de Comunicação, Cultura e Mídia, São Paulo, n.5. 2004.

FILHO,Vilson Martins e FIALHO, Francisco Antonio Pereira. O Ciberespaço e a inevitabilidade semiótica do meme na educação digital, 2011. Trabalho apresentado no V Simpósio Nacional da ABCiber, Florianópolis, 2011. 
FONTANELLA, Fernando. O que vem de baixo nos atinge: intertextualidade, reconhecimento e prazer na cultura digital trash. Trabalho apresentado no IX Encontro dos Grupos/Núcleos de Pesquisas em Comunicação, evento componente do XXXII Congresso Brasileiro de Ciências da Comunicação, Curitiba, 2009a.

O que é um meme na Internet? Proposta para uma problemática da memesfera. Trabalho apresentado no III Simpósio Nacional da ABCiber, São Paulo, 2009 b.

Nós somos Anonymous: anonimato, trolls e a subcultura dos imageboards. Trabalho apresentado no GP de Cibercultura do IX Encontro dos Grupos de Pesquisa em Comunicação, evento componente do XXXIII Congresso Brasileiro de Ciências da Comunicação, Caxias do Sul, 2010.

Explorações da cibercultura vernacular: digital trash, ironia e a domesticação da Internet. Trabalho apresentado no DT 05 - Comunicação Multimídia do XIII Congresso de Ciências da Comunicação na Região Nordeste, Maceió, 2011.

Memes como Consumerismo: O Caso de Mass Effect 3. Trabalho apresentado no GP de Cibercultura do XII Encontro dos Grupos de Pesquisa em Comunicação, evento componente do XXXV Congresso Brasileiro de Ciências da Comunicação, Fortaleza, 2012.

GLOCK, Hans - Johann. Forma de vida. In: Dicionário de Wittgenstein. Rio de Janeiro: Jorge Zahar Editor Ltda,1998, p.173-178.

Jogo de linguagem. In: Dicionário de Wittgenstein. Rio de Janeiro: Jorge Zahar Editor Ltda,1998, p.225-229.

Uso. In: Dicionário de Wittgenstein. Rio de Janeiro: Jorge Zahar Editor Ltda,1998, p.359-363.

GOMES, Walter. O conceito peirceano de terceiridade como sustentação para o meio de comunicação como extensão do homem. In: RUSSI, Pedro (Org.). Processos Semióticos em Comunicação. Brasília: Editora UnB, 2013, p.269-283.

GORLÉE, Dinda L. La semiótica triádica de Peirce y su aplicación a los géneros literários. Signa: revista de la Asociación Española de Semiótica (Edição digital da Biblioteca Virtual Miguel de Cervantes por cortesia do editor). Madrid, n.1, p.12-51. 1992.

HACKER, P.M.S. Thinking: the soul of language. In: Wittgenstein: Meaning and Mind, Volume 3 of an Analytical Commentary on the Philosophical Investigation, Part I: Essays. Oxford: Blackwell, 1993, p.161-182.

HENN, Ronaldo. Ciberacontecimiento: otros modos de producir y narrar. In: El ciberacontecimiento: producción y semiosis. Barcelona: Institut de la Comunició Universitat Autònoma de Barcelona; Editorial UOC, 2014, p.37-50.

HUTCHEON, Linda. Uma Teoria da Paródia. Lisboa: Edições 70, 1985. 
KNOBEL, Michele; LANKSHEAR, Colin. Online Memes, Affinities, and Cultural Production . In:

2007, p. $199-227$. (Org.). A new literacies sampler. Nova Iorque: Peter Lang,

KULL, Kalevi. Semiosfera e a ecologia dual: paradoxos da comunicação. Irene (Org.). Semiótica da Cultura e Semiosfera. São Paulo: Annablume, 2007, p.69-79.

LARIZZATTI, Dóris Sathler de Souza. Da Semiosfera à Ludosfera: por uma Filosofia do Jogo de Linguagem na Hipermídia. Animus - Revista Interamericana de Comunicação Midiática. Santa Maria v.12, n.23, p. 306-329. 2013.

LEMOS, André. Ciber-cultura-remix. Artigo escrito para apresentação no seminário "Sentidos e Processos" dentro da mostra "Cinético Digital', no Centro Itaú Cultural. Tema da mesa: "Redes: criação e reconfiguração", São Paulo, Itaú Cultural, ago. de 2005

Lixo ou Luxo na Cibercultura? Origens e atualidades da cultura "digital trash". In PEREIRA, Vinícius A, (org.), Cultura Digital Trash: Linguagens, Comportamentos e Desafios. Rio de Janeiro, E-Papers, 2007, p. 142-8.

Cibercultura, tecnologia e vida social na cultura contemporânea. Porto Alegre: Sulina, $4^{\mathrm{a}}$ ed., 2008.

LOTMAN, Iuri M. Acerca de la semiosfera. In: La Semiosfera 1. Semiótica de la cultura y del texto. Madrid: Cátedra, 1996, p. 21-42.

LOZANO, Jorge. La Semiosfera y La teoria de la cultura. Revista de Occidente, n. 145-146, jul./ago. 1995. Disponível em: https://pendientedemigracion.ucm.es/info/especulo/numero8/lozano.htm> Acesso em 13/11/2014>

Cultura y explosión en la obra de Yuri M. Lotman. Revista Espéculo, ano IV, n.11, ago. $1999 . \quad$ Disponível em <http://pendientedemigracion.ucm.es/info/especulo/numero11/lotman2.html> Acesso em 20/12/2014

LUIZ, Lúcio. Ffffffuuuuuuuuuuuu: o fenômeno das rage comics e sua relação com os quadrinhos. Trabalho apresentado no XXXV Congresso Brasileiro de Ciências da Comunicação, Fortaleza, 2012.

MACHADO, Irene. Circuitos Dialógicos: Para Além da Transmissão de Mensagens. In: (Org.) Semiótica da Cultura e Semiosfera. São Paulo: Annablume/Fapesp, 2007, p. 57-68.

Gramática dos meios no contexto das linguagens icônicas. LOGOS 36 Comunicação e Entretenimento: Práticas Sociais, Indústrias e Linguagens. v.19, n.01, p.6-18, $1^{\mathrm{o}}$ semestre 2012.

Pensamento semiótica sobre a cultura. Sofia, Vitória, v.2, n.2, ago. 2013. 
MACHADO, Rosemeri Passos Baltazar. O Discurso Parodístico: da Constituição à Comunicação. SIGNUM: Estud. Ling., Londrina, n. 15/3 (esp), p. 247-271, dez. 2012.

MARCONDES, Danilo. Textos básicos de Linguagem: de Platão a Foucault. Rio de Janeiro: Jorge Zahar Ed., 2009.

MARTINO, Luiz C. Contribuições para o estudo dos meios de comunicação. Revista FAMECOS: mídia, cultura e tecnologia, Porto Alegre, v. 1, n.13, p.103-114, dez. 2000.

MATOS, José Cláudio Morelli. Concepções Evolucionistas da Cultura e a Questão da Educação. In: Educação e Filosofia. Uberlândia, v. 22, n. 43, p. 33-61, jan./jun. 2008.

MCLUHAN, Marshall. A galáxia de Gutenberg. São Paulo: Companhia Editora Nacional, 1966.

MENÉNDEZ, Jimena García; CARIGNANO, Maria Laura Moneta. Humor, surrealismo e absurdo na obra de Alejandra Pizarnik. II Colóquio de Psicologia da Arte. A correspondência das artes e a unidade dos sentidos. Caderno de resumos. São Paulo: Instituto de Psicologia - USP, 2007.

MERRELL, Floyd. Charles Peirce y sus signos. Signos en Rotación, Pamplona, Ano III, n. 181. 2001.

Iúri Lótman, C. S. Peirce e semiose cultural. Galáxia, São Paulo, n. 5, p. 163185, abril. 2003.

MEYROWITZ, Joshua. Medium theory. In: D. Crowley \& D. Mitchell (org). Communication Theory Today. Cambridge: Polity Press, 1994. p. 50-77.

As múltiplas alfabetizações midiáticas. Revista FAMECOS, Porto Alegre, n.15, p. 88-100, ago. 2001.

. Media as Change Mechanisms. In: No Sense of Place. Nova Iorque: Oxford University Press, 1986, p.13-34.

From Print Situations to Electronic Situations. In: No Sense of Place. Nova Iorque: Oxford University Press, 1986, p.69-125.

MILLER, Jonathan. A linguagem, a escrita e os meios de comunicação. In: As Idéias de McLuhan. São Paulo: Mestres da Modernidade/Cultrix, 1971, p. 83 - 118.

MILNER, Ryan. M. The world made meme: discourse and identity in participatory media. Kansas: University of Kansas. 316f. Tese (Doutorado em Comunicação) University of Kansas, Kansas, 2012.

MINOIS, Georges. O riso unificado dos latinos. In: História do Riso e do Escárnio. São Paulo: Editora UNESP, 2003, p.77-109. 
O riso unânime da festa medieval. In: História do Riso e do Escárnio. São Paulo: Editora UNESP, 2003, p.153-191.

Século XX: morrer de rir. In: História do Riso e do Escárnio. São Paulo: Editora UNESP, 2003, p.553-592.

MIRANDA, Wander Melo. A Liberdade do Pastiche. In: Nações Literárias. Cotia: Ateliê Editorial, 2010, p. 131- 136.

MORAIN, Matthew. Rhetorical Transmisson and Internet Memes. ENG 798c | Dr. Carolyn Miller, 2009. Disponível em <http://mattmorain.com/downloads/Rhetorical\%20Transmission\%20and\%20Internet $\% 2$ 0Memes\%5BDIST\%5D.pdf> Acesso em 14 de setembro de 2012.

NAKAGAWA, Regiane. Os ambientes e os contra-ambientes: uma possível epistemologia dos meios. Trabalho apresentado no XIII Encontro dos Grupos de Pesquisa - evento componente do XXXVI Congresso Brasileiro de Ciências da Comunicação, Manaus, 2013.

NETTO, José Teixeira Coelho. Semiótica: Charles S. Peirce. In: Semiótica, Informação e Comunicação. São Paulo: Editora Perspectiva, 1980, p. 51-81.

NEVES, Cristiano. Os jogos de linguagem e a filosofia terapêutica de Wittgenstein. 2008. 84f. Dissertação (Mestrado em Ciências da Linguagem). Universidade do Sul de Santa Catarina, Palhoça. 2008.

NÖTH, Winfred. Termo, origens e precursores da semiótica. In: Panorama da semiótica: de Platão a Peirce. São Paulo: Annalume, 1995, p. 17-24.

Signos a partir da vida de organismos, espécies, linguagens e mídias. In:semeiosis, semiótica e transdisciplinaridade em revista. $1^{\mathbf{0}}$ semestre 2012, disponível em <http://www.semeiosis.com.br/signos-a-partir-da-vida-de-organismosesp\%C3\%A9cies-linguagens-e-m\%C3\%ADdias/> Acesso em 25 de setembro de 2012.

Iuri Lotman: a cultura e suas metáforas como semiosferas auto-referenciais. In: MACHADO, Irene (Org.). Semiótica da Cultura e Semiosfera. São Paulo: Annablume, 2007, p. 81-85.

NUBIOLA, Jaime . La abducción o lógica de la sorpresa. Razón y Palabra, México, ${ }^{\circ}$ 21, março de 2001.

La investigación de las relaciones entre Ludwig Wittgenstein y Charles S. Peirce. Topos y Tropos, verão de 2006.

PEARS, David. A filosofia de Wittgenstein - segunda época. In: As ideias de Wittgenstein. São Paulo: Cultrix, 1988, p.97-187.

PEIRCE, Charles Sanders. Collected Papers. (CP) C. Hartshorne, P. Weiss e A. W. Borks (Ed.). Cambridge, MA: Havard U. Press (acervo pessoal digital). 
PEREIRA, Vinícius Andrade. As tecnologias de Comunicação como gramáticas: meio, conteúdo e mensagem na obra de Marshall McLuhan. Contracampo (UFF), Niteroi - RJ, v. 10/11, p. 07-20, 2004.

;HECKSHER, Andrea Dantas. Economia da Atenção e Mensagens Publicitárias na Cultura Digital Trash. Trabalho apresentado no Encontro dos Núcleos de Pesquisa em Comunicação, evento componente do XXXI Congresso Brasileiro de Ciências da Comunicação. Natal, 2008.

A Teia Global: McLuhan e Hipermídias, disponível em <http://leatrice.files.wordpress.com/2008/05/aldeiaglobal.pdf> Acesso em 13 de setembro de 2013.

PINHEIRO, Kelly Cristina Lourenço. Hipérbole como argumento retórico. Revista Parágrafo: Revista Científica de Comunicação Social da FIAM-FAAM. São Paulo: v.1, n.1, p.147-160.

PINTO, Zélio Alves. Quase toda a história do século XXI no Humor do O Pasquim 21. Editora Gampz, 2005.

PIRANDELLO, Luigi. Essência, características e matéria do humorismo. In: O Humorismo. São Paulo: Experimento, 1996, p.125-169.

PRIMO, Alex. Digital trash e lixo midiático: A cauda longa da micromídia digital. In: Vinicius Andrade Pereira. (Org.). Cultura Digital Trash: Linguagens, Comportamentos, Entretenimento e Consumo. Rio de Janeiro: e- Papers, 2007a, p. 77-93.

O aspecto relacional das interações na Web 2.0. Revista da Associação Nacional dos Programas de Pós-Graduação em Comunicação. Brasília: ago. 2007b.

PONZIO, Augusto. Bakhtin e Peirce: signo, interpretação, compreensão. In: A revolução bakhtiniana. São Paulo: Contexto, 2011, p.161-168.

Bakhtin e Propp: festa, carnaval e literatura. In: A revolução bakhtiniana. São Paulo: Contexto, 2011, p. 169-183.

Diálogo e dialética. In: A revolução bakhtiniana. São Paulo: Contexto, 2011, p. 185-188.

PROPP, Vladímir. Comicidade e Riso. São Paulo: Editora Ática S.A., 1992.

QUINN, Daniel. Além da Civilização. A Próxima Grande Aventura da Humanidade. São Paulo: Editora Peirópolis, 2001, p.8-59.

RAMOS, Adriana Vaz et al. Semiosfera: exploração conceitual nos estudos semióticos da cultura. In: MACHADO, Irene (Org.). Semiótica da Cultura e Semiosfera. São Paulo: Annablume, 2007, p.27-44. 
RECUERO, Raquel. Memes e Dinâmicas Sociais em Weblogs: informação, capital social e interação em redes sociais na internet. Intexto, Porto Alegre: UFRGS, v. 2, n. 15, p. 1-16, jul./dez. 2006.

Memes em weblogs: proposta de uma taxonomia. Revista FAMECOS. Porto Alegre, n.32, abr. 2007a.

.O Digital Trash como Mainstream: Considerações sobre a difusão de informações em redes sociais na Internet. In: Vinícius Andrade Pereira. (Org.). Cultura Digital Trash: Linguagens, Comportamentos e Desafios. Rio de Janeiro: E-papers, $2007 b$.

REGINATTO, Andréa Ad. Riso e ironia na construção paródica: uma leitura de o pagador de promessas. Anais do SITED -Seminário Internacional de Texto, Enunciação e Discurso Núcleo de Estudos do Discurso Pontifícia Universidade Católica do Rio Grande do Sul. Porto Alegre, RS, setembro de 2010.

RUSSI, Pedro. Provocações e ação do signo: "pichações". In:

Semióticos em Comunicação. Brasília: Editora UnB, 2013, p. 45-71.

(Org.). Processos

SANTAELLA, Lucia. O que é semiótica. São Paulo: Brasiliense, 1983.

Bases teóricas para a aplicação. In: Semiótica Aplicada. São Paulo Cengage Learning, 2002, p. 2-27.

Fontes e Propósitos das Matrizes e Classificações. In: Matrizes da Linguagem

e Pensamento. Sonora, Visual e Verbal. São Paulo: Iluminuras, 2005.

Do Signo. In: A Teoria Geral dos Signos. Como as linguagens significam as coisas. São Paulo: Cengage Learning, 2008.

O conceito de semiosfera à luz de C.S.Peirce. In: Irene (Org.). Semiótica da Cultura e Semiosfera. São Paulo: Annablume, 2007, p.113-123.

SANTAELLA; NÖTH W. Lotman: comunicação, código e cultura. In: Comunicação e Semiótica. São Paulo: Hacker Editores, 2004, p. 135-143.

Panorama do campo semiótico. In: Comunicação e Semiótica. São Paulo: Hacker Editores, 2004, p. 68-81.

SANT'ANNA, Affonso Romano de. Paródia, Paráfrase \&Cia. São Paulo: Editora Ática S.A., 1988.

SEARLE, John R. A Redescoberta da mente. São Paulo: Martins Fontes, 1997.

SILVA, Flávio Augusto Queiroz e. Linguagem como jogo dialógico nas teorias de Bakhtin e Wittgenstein. In: Revista Rastros. Ano 13, n. 16, jul. 2012. 
. "Modificação do acontecimento" como semiose: a relação entre meios e sociedade em uma perspectiva semiótica. 2013. 226f. Dissertação (Mestrado em Comunicação) - Programa de Pós-Graduação em Comunicação da Universidade de Brasília, Brasília. 2013.

SODRÉ, Muniz; PAIVA, Raquel. O Império do Grotesco. Rio de Janeiro: MAUAD Editora Ltda., 2002.

SPANIOL, Werner. "Formas de vida": significado e função no pensamento de Wittgenstein. Síntese, Belo Horizonte, v. 17, p. 11-31. 1990.

SPERBER, Dan. An objection to the memetic approach to culture. In: AUNGER, Robert. Darwinizing Culture: The Status of Memetics as a Science. Oxford University Press, p. 163-173, 2000.

TOLEDO, Gustavo Leal. Sobre a possibilidade de um ciência dos memes. Alter, Rio de Janeiro, Ano VII, n. 8, p. 2-3, 2007.

. Memes e Memética, um Início. In: Controvérsias Meméticas: a ciência dos memes e o darwinismo universal em Dawkins, Dennett e Blackmore. Rio de Janeiro, 2009. 467p. Tese de Doutorado - Departamento de Filosofia, Pontifícia Universidade Católica do Rio de Janeiro, 2009.

Em Busca de uma Fundamentação para a Memética. Trans/Form/Ação, Marília, v. 36, n. 1, p. 187-210, Jan./Abr. 2013.

TOROP, Peeter. Semiosfera como objeto de pesquisa na semiótica da cultura. In: MACHADO, Irene (Org.). Semiótica da Cultura e Semiosfera. São Paulo: Annablume, 2007, p.45-56.

VELLOSO, Araceli. Forma de vida ou formas de vida? Philósophos, Goiânia, p.159184, jul./dez. 2003.

WILLIAMS, Meredith. Wittgenstein on representations, privileged objects, and private languages. In: Wittgenstein, Mind and Meaning. Nova Iorque: Routeledge, 1999, p.15-33.

WITTGENSTEIN, Ludwig. Investigações Filosóficas. São Paulo: Editora Nova Cultura Ltda., 1999.

\section{Vídeos}

BLACKMORE, Susan. Susan Blackmore: Memes and "temes". TED 2008

(Comunicação oral) disponível

em<http://www.ted.com/talks/susan_blackmore_on_memes_and_temes.html > Acesso em 26 de janeiro de 2014.

DAWKINS, Richard. Just for Hits, disponível em <

http://www.youtube.com/watch?v=GFn-ixX9edg> Acesso em 17/10/2014 